UNIVERSIDADE DE BRASÍLIA - UnB

FACULDADE DE ARQUITETURA E URBANISMO

PROGRAMA DE PESQUISA E PÓS-GRADUAÇÃO

SOBRE O ENSINO DA SUSTENTABILIDADE AMBIENTAL NOS CURSOS DE ARQUITETURA E URBANISMO:

AVALIAÇÃO E SUBSÍDIOS

BRENDA MILHOMEM DOURADO

DISSERTAÇÃO DE MESTRADO EM ARQUITETURA E URBANISMO

PUBLICAÇÃO: $\quad / 2015$

BRASÍLIA/DF: MARÇO - 2015 
UNIVERSIDADE DE BRASÍLIA - UnB

FACULDADE DE ARQUITETURA E URBANISMO

PROGRAMA DE PESQUISA E PÓS-GRADUAÇÃO

\section{SOBRE O ENSINO DA SUSTENTABILIDADE AMBIENTAL NOS CURSOS DE ARQUITETURA E URBANISMO: AVALIAÇÃO E SUBSÍDIOS}

\section{BRENDA MILHOMEM DOURADO}

DisSERTAÇÃo DE MESTRAdO SUBMETIDA AO PROGRAMA DE PESQUISA E PÓS-GRADUAÇÃO DA FACULDADE ARQUITETURA E URBANISMO DA UNIVERSIDADE DE BRASÍLIA, COMO PARTE DOS REQUISITOS NECESSÁRIOS PARA A OBTENÇÃO DO GRAU DE MESTRE EM ARQUITETURA E URBANISMO.

APROVADA POR:

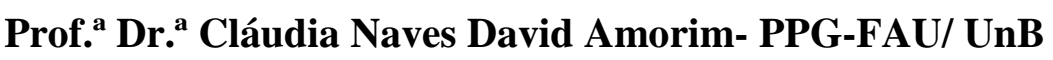
(Orientadora)

Prof. ${ }^{a}$ Dr. a Cláudia da Conceição Garcia - FAU/ UnB (Examinadora Interna)

Prof. ${ }^{a}$ Dr. ${ }^{a}$ Alexandra Albuquerque Maciel- UniCEUB - DF (Examinadora Externa) 


\section{FICHA CATALOGRÁFICA}

DOURADO, Brenda $\mathrm{M}$.

SOBRE O ENSINO DA SUSTENTABILIDADE AMBIENTAL NOS CURSOS DE ARQUITETURA E URBANISMO: AVALIAÇÃO E SUBSÍDIOS, [Distrito Federal] 2015.

233p., 210 x 297 mm (PPG/FAU/UnB, Mestre, 2015). Dissertação de Mestrado Universidade de Brasília. Faculdade de Arquitetura e Urbanismo. Programa de Pesquisa e Pós-Graduação.
1. ENSINO
2. ARQUITETURA E URBANISMO
3. SUSTENTABILIDADE
4. CURRÍCULO
I. FAU UnB.

\section{REFERÊNCIA BIBLIOGRÁFICA}

DOURADO, Brenda M. (2015). SOBRE O ENSINO DA SUSTENTABILIDADE AMBIENTAL NOS CURSOS DE ARQUITETURA E URBANISMO: AVALIAÇÃO E SUBSÍDIOS. Dissertação de Mestrado em Arquitetura e Urbanismo, Universidade de Brasília, DF, 233p.

\section{CESSÃO DE DIREITOS}

AUTOR: Brenda Milhomem Dourado.

TÍTULO: SOBRE O ENSINO DA SUSTENTABILIDADE AMBIENTAL NOS CURSOS

DE ARQUITETURA E URBANISMO: AVALIAÇÃO E SUBSÍDIOS.

GRAU: Mestre.

ANO: 2015

É concedida à Universidade de Brasília permissão para reproduzir cópias desta Dissertação de Mestrado e emprestar ou vender tais cópias somente para propósitos acadêmicos e científicos. O autor reserva outros direitos de publicação e nenhuma parte desta Dissertação de Mestrado pode ser reproduzida sem a autorização por escrito do autor.

BRENDA MILHOMEM DOURADO, 2015

Rod. DF-425, km 1. Cond. Fraternidade. CJ 05, C4. St. Habit. Contagem - Sobradinho.

CEP: 73092-912. Brasília, DF - Brasil. 
Dedico este trabalho à minha querida mãe,

Edmarine Milhomem Dourado (In Memoriam) 


\section{AGRADECIMENTOS}

A Deus, acima de tudo, pela permissão de concluir este trabalho depois de tão longa jornada.

Ao meu companheiro, Leandro, sem o qual esta dissertação não seria concluída. Assessor multidisciplinar, auxiliou-me nos cuidados com nosso filho e casa, além das etapas técnicas da dissertação.

Ao meu filho querido, Benjamim, por compreender a minha ausência em diversos momentos e por me trazer esperança nos momentos mais difíceis.

Ao meu pai, irmão, tias, primas e amigos. Agradeço, especialmente, à colega e amiga Débora, que esteve presente em vários momentos da caminhada.

Aos colegas do Instituto Nacional do Seguro Social (INSS) que me apoiaram, e aos chefes que autorizaram meu afastamento para conclusão da dissertação, Carlos Eduardo, Manuella, Gilvaneire e Lenilson.

Aos professores e funcionários do Programa de Pós Graduação da Faculdade de Arquitetura e Urbanismo da UnB (PPG/FAU/UnB).

À banca de qualificação, professoras Raquel Naves Blumenschein e Cláudia da Conceição Garcia, pelas contribuições decisivas dos rumos da pesquisa.

À banca de defesa, professoras Cláudia da Conceição Garcia e Alexandra Albuquerque Maciel, pelas contribuições finais para o fechamento satisfatório da pesquisa.

E, claro, à professora Cláudia Naves David Amorim, por todas as orientações e, principalmente, por acreditar no meu trabalho e em mim. 


\title{
RESUMO
}

\section{SOBRE O ENSINO DA SUSTENTABILIDADE AMBIENTAL NOS CURSOS DE ARQUITETURA E URBANISMO: AVALIAÇÃO E SUBSÍDIOS}

\author{
Autor: Brenda Milhomem Dourado \\ Orientador: Prof. ${ }^{a}$ Dr. ${ }^{a}$ Cláudia Naves David Amorim \\ Programa de Pós-Graduação em Arquitetura e Urbanismo da UnB \\ Brasília, Março de 2015.
}

A temática da sustentabilidade tem estado presente nos principais discursos da atualidade que englobam desequilíbrios climáticos, energéticos, ambientais, econômicos, dentre outros. Nesse contexto, destaca-se a expressividade dos impactos decorrentes da construção civil que perpassam pela área de Arquitetura e Urbanismo. Desta forma, tem-se verificado uma exigência cada vez maior de capacitação técnica voltada à promoção da sustentabilidade do ambiente construído, incluindo a atualização de cursos de Arquitetura e Urbanismo de modo a atender a essas demandas. Logo, a presente dissertação é focada no ensino da sustentabilidade nos cursos de Arquitetura e Urbanismo, com ênfase na dimensão ambiental, e teve como objetivo geral fornecer subsídios ao mesmo.

A metodologia consistiu, primeiramente, em revisão bibliográfica nacional e internacional a respeito da delimitação da sustentabilidade e do ensino desta temática na história da Arquitetura e Urbanismo. A revisão também verificou o método de análise curricular desenvolvido pelo grupo EDUCATE (Environmental Design in University Curricula and Architectural Training in Europe). Num segundo momento, foram identificados e selecionados cursos de Arquitetura e Urbanismo brasileiros que tiveram grande destaque em três importantes eventos de alcance nacional voltados à sustentabilidade, são eles: Universidade Federal do Rio Grande do Norte- UFRN; Universidade Federal do Rio Grande do Sul -UFRGS; Universidade de São Paulo - USP; e Universidade de BrasíliaUNB. Por fim, estes cursos foram analisados utilizando-se o método do EDUCATE e análises adicionais e tiveram como fonte de dados os projetos político pedagógicos, currículos, planos de ensino e questionários on-line enviados para os professores.

Como resultados, considerando o método do EDUCATE, identificou-se que os currículos dos cursos da UFRGS, USP e UNB se classificaram como "Parcialmente Integrados"; e o curso da UFRN como "Totalmente Integrado". E considerando as demais análises do trabalho, concluiu-se que a integração entre a teoria e a prática (esteja ela no domínio da disciplina ou envolvendo disciplinas distintas); a carga horária dedicada aos conteúdos (seja ela em disciplinas especializadas no tema ou em disciplinas já existentes); a oferta de disciplinas eletivas voltadas ao tema; e a presença da temática ao longo de grande parte do curso, são alguns dos fatores que influenciam na qualidade do ensino ofertado. Estas observações, juntamente com os quantitativos levantados de cada curso, podem servir de referência e subsidiar o ensino da temática por meio da elaboração e revisão de currículos e projetos político pedagógicos de cursos de Arquitetura e Urbanismo no Brasil.

Palavras-chaves: ensino, Arquitetura e Urbanismo, sustentabilidade, currículo. 


\title{
ABSTRACT \\ ABOUT ENVIRONMENTAL SUSTAINABILITY TAUGHT IN ARCHITECTURE AND URBAN DESIGN COURSES: AVALIATION AND SUBSIDIES
}

\author{
Author: Brenda Milhomem Dourado \\ Supervisor: Prof. ${ }^{a}$ Dr. ${ }^{\text {a }}$ Cláudia Naves David Amorim \\ Post-Graduation Program in Architecture and Urban Design - UnB \\ Brasília, March of 2015.
}

Sustainability has been included in the most important and present discussions about climate, environment, energy and economic imbalances. In this context the Architecture and Urban Design has an expressive impact. A growing demand for technical training about sustainability building design is evident, including a restructuring of the Architecture and Urban Design courses curriculums. Therefore, the present work is focused on the sustainability taught in the Architecture and Urban Design courses, with emphasis on the environmental dimension, and propose provide subsidies to it.

The methodology starts with a national and international literature review on the definitions about sustainability, history about sustainability taught in the Architecture and Urban Design courses and a review of the curriculum analysis method developed by EDUCATE group (Environmental Design in University Curricula and Architectural Training in Europe). Then, were identified some Architecture and Urban Design courses from Brazil that figured prominently in three important events about sustainability analyzed. They are: Universidade Federal do Rio Grande do Norte - UFRN; Universidade Federal do Rio Grande do Sul - UFRGS; Universidade de São Paulo - USP; and Universidade de Brasília - UNB. As follows, these courses were analyzed, using the method from EDUCATE and considering additional factors, from their political pedagogical projects, curricula, teaching plans and were sent online survey for teachers.

As results, we identified that the curricula of UFRGS, USP and UNB courses are "Partially Integrated"; and the UFRN course is "Fully Integrated", considering the EDUCATE method. It also identified some factors that may had influenced the good results in education: the integration between theory and practice (in the field of module or involving different modules); the amount of hours devoted to the sustainability content (in specialized modules or other modules); the offer of electives specialized modules; and the presence of the sustainability content throughout the entire course. These observations and data from each course analyzed can be references in sustainability education and support to the development or revision of curricula and political-pedagogical projects of Architecture and Urban Design courses in Brazil.

Key-words: taught, Architecture and Urban Design, sustainability, curriculum. 


\section{SUMÁRIO}

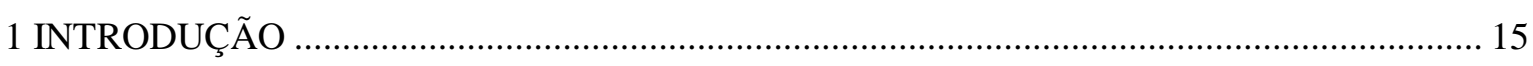

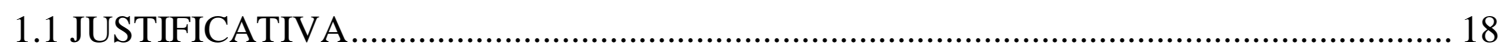

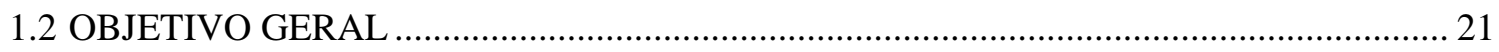

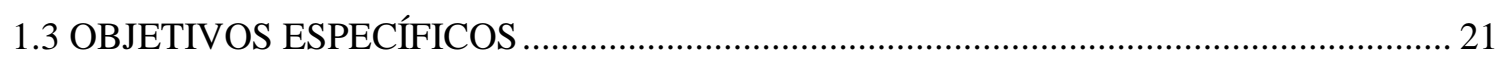

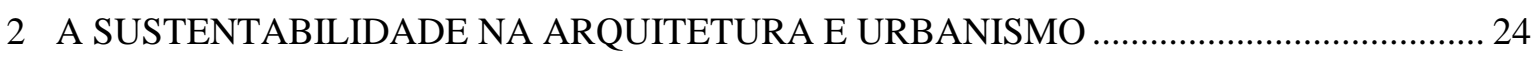

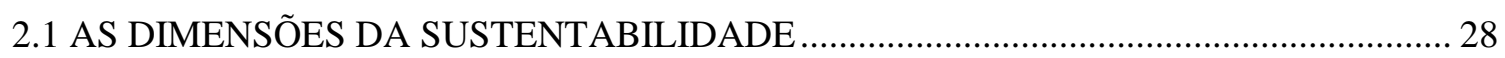

2.2 O CONTEXTO DA SUSTENTABILIDADE AMBIENTAL NA ARQUITETURA E

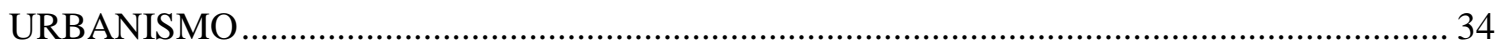

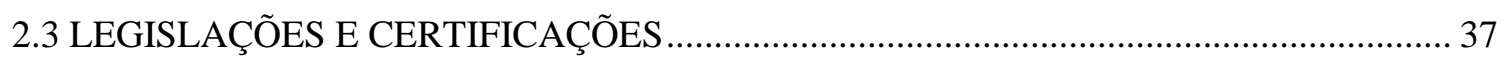

3 O ENSINO DA SUSTENTABILIDADE NA ARQUITETURA E URBANISMO ...................... 44

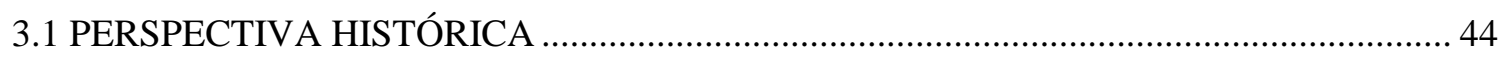

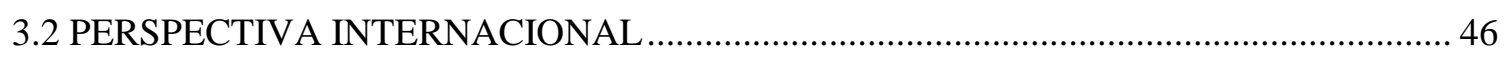

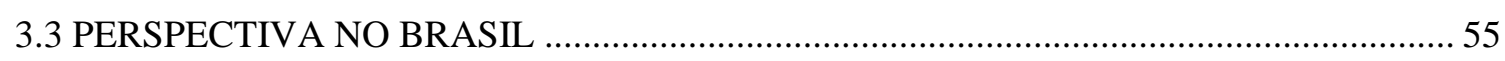

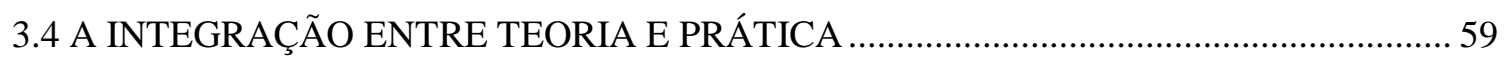

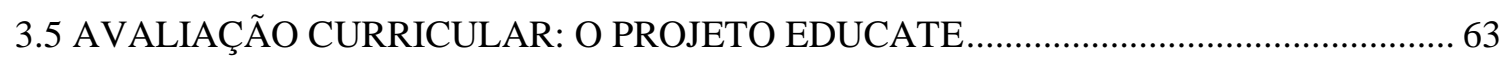

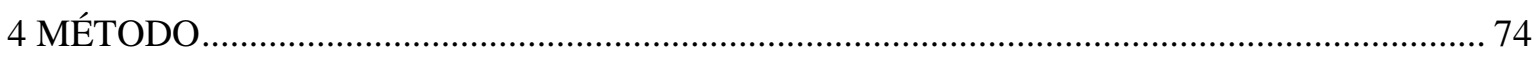

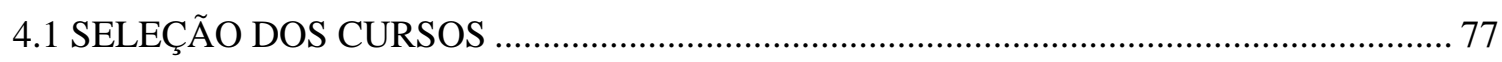

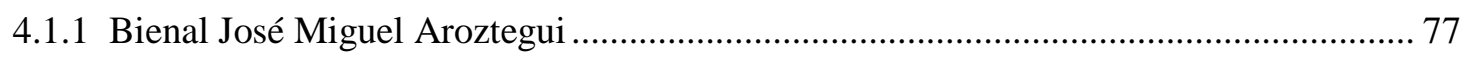

4.1.2 Bienal de Sustentabilidade José Lutzenberger .......................................................... 79

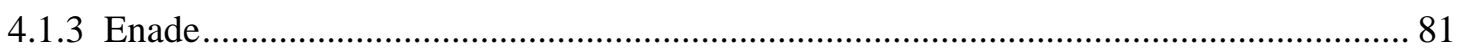

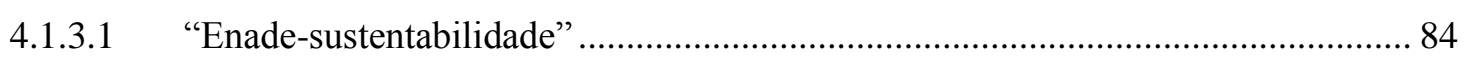

4.2 LEVANTAMENTO E SISTEMATIZAÇÃO DOS DADOS ……...................................... 90

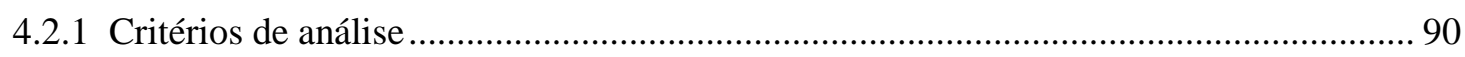

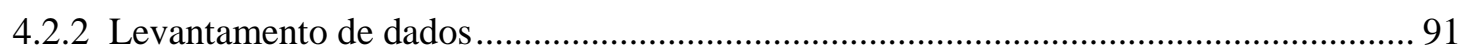

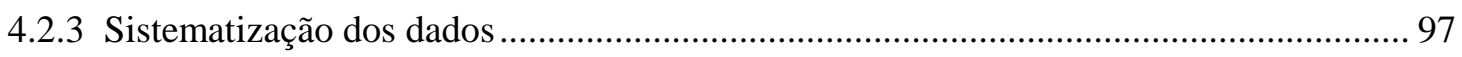

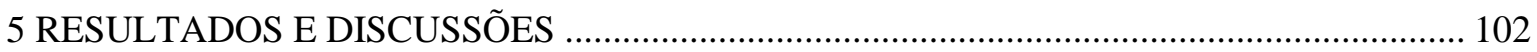

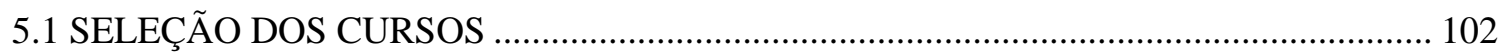

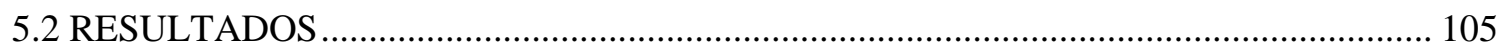

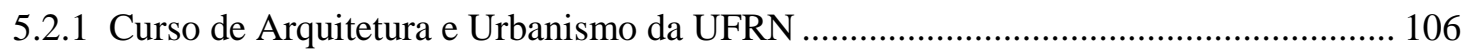

5.2.2 Curso de Arquitetura e Urbanismo da UFRGS ........................................................ 113

5.2.3 Curso de Arquitetura e Urbanismo da USP............................................................. 118

5.2.4 Curso de Arquitetura e Urbanismo da UnB ............................................................. 124

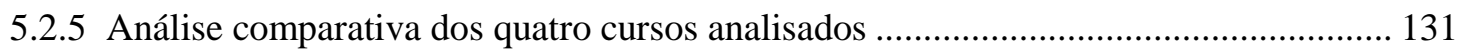

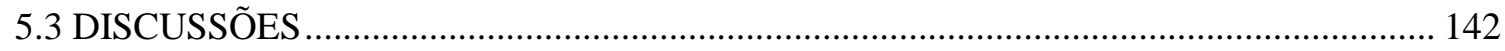

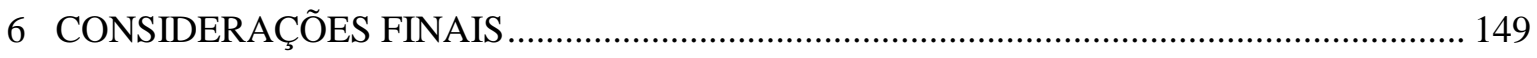




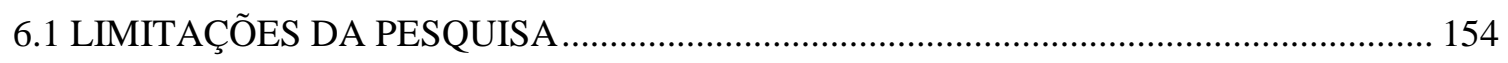

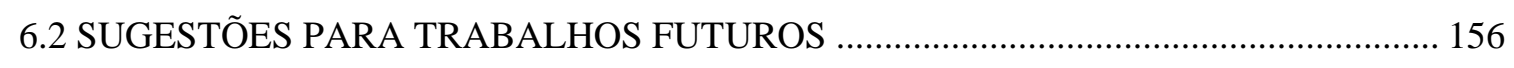

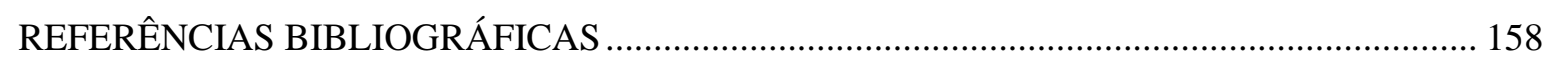

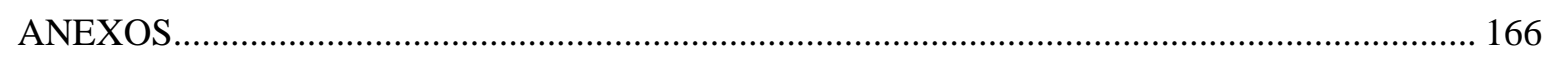

ANEXO 1: QUESTÕES SELECIONADAS DA PROVA DE ARQUITETURA- ENADE 2011 QUE ABORDARAM A SUSTENTABILIDADE COM OS RESPECTIVOS GABARITOS E

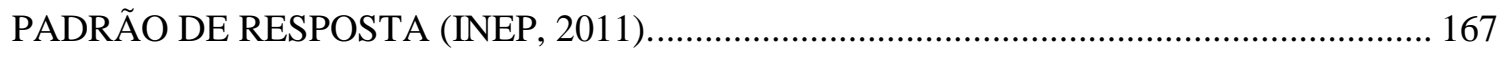

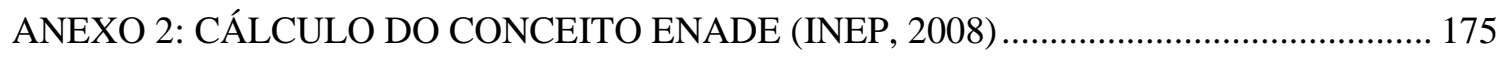

ANEXO 3: ESTRUTURA CURRICULAR DA FAU- UFRN ............................................. 181

ANEXO 4: ESTRUTURA CURRICULAR DA FAU- UFRGS............................................. 184

ANEXO 5: ESTRUTURA CURRICULAR DA FAU- USP …............................................. 188

ANEXO 6: ESTRUTURA CURRICULAR DA FAU- UNB …................................................... 194

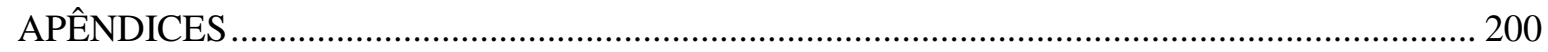

APÊNDICE 01: NOTAS FINAIS DE CADA ESCOLA PARA O "ENADE-

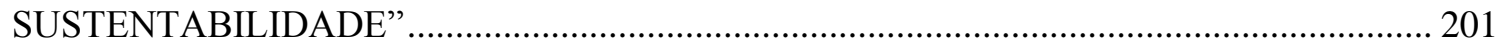

APÊNDICE 02: CLASSIFICAÇÃO DAS DISCIPLINAS POR MÓDULO-TEMA ................. 217

APÊNDICE 03: SUSTENTABILIDADE NO CURRÍCULO DA UFRN ................................... 219

APÊNDICE 04: SUSTENTABILIDADE NO CURRÍCULO DA UFRGS ………................... 222

APÊNDICE 05: SUSTENTABILIDADE NO CURRÍCULO DA USP ………............................ 226

APÊNDICE 06: SUSTENTABILIDADE NO CURRÍCULO DA UNB ….............................. 230 


\section{LISTA DE QUADROS}

Quadro 1: Dimensões da sustentabilidade (adaptado de Sachs,1993, p.25) ………........................ 29

Quadro 2: Pétalas para a sustentabilidade (Living Building Challenge, 2010) ............................... 30

Quadro 3: Questões e princípios da sustentabilidade na Arquitetura e Urbanismo (Adaptado de EDUCATE, 2011)

Quadro 4: Descrição sucinta dos modelos paradigmáticos das estruturas curriculares de ensino da Arquitetura e Urbanismo (adaptado de EDUCATE, 2012 a).

Quadro 5: Propostas para aprimoramento dos currículos conforme o EDUCATE (2012a) adaptado 


\section{LISTA DE TABELAS}

Tabela 1: Ajustes nos pesos entre questões objetivas e subjetivas do Enade para o "EnadeSustentabilidade"

Tabela 2: Conceitos adotados pelo Enade conforme as notas finais dos cursos ............................... 87

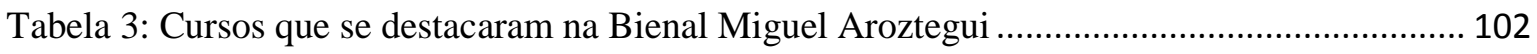

Tabela 4: Cursos que se destacaram na Bienal José Lutzenberger ............................................... 103

Tabela 5: Cursos que se destacaram no "Enade-sustentabilidade" ................................................. 103

Tabela 6: Cruzamento de dados para seleção dos cursos a serem analisados................................. 104

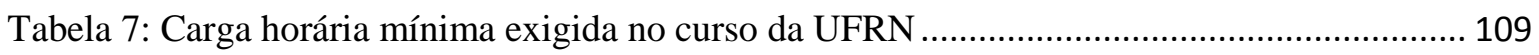

Tabela 8: Carga horária mínima exigida no curso da UFRGS ..................................................... 113

Tabela 9: Créditos e carga horária necessários para a conclusão do curso de Arquitetura e

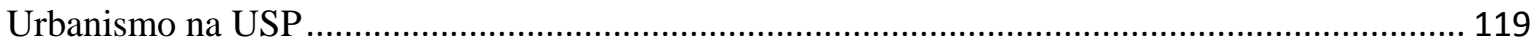

Tabela 10: Créditos e carga horária mínima exigida no curso da UnB .......................................... 126

Tabela 11: Carga horária por tipo de disciplina e curso ............................................................ 132

Tabela 12: Carga horária por abordagem da sustentabilidade (inclui todas disciplinas que abordam

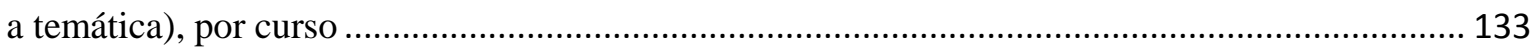

Tabela 13: Recorrência de métodos de ensino nas disciplinas especializadas ................................ 138

Tabela 14: Recorrência de métodos de ensino nas disciplinas de projeto....................................... 139

Tabela 15: Recorrência de critérios de avaliação nas disciplinas especializadas ............................ 140

Tabela 16: Recorrência de critérios de avaliação nas disciplinas de projeto ................................. 141

Tabela 17: Número de cursos por conceito no "Enade-Sustentabilidade".................................... 147 


\section{LISTA DE FIGURAS}

Figura 1: Cadeia Produtiva da Indústria da Construção- CPIC (Adaptado de Blumenschein, 2004, p.45)

Figura 2: Varrendo impactos (adaptado de Blumenschein, 2004, p.48) …...................................... 32

Figura 3: Um bacharelado idealizado em Arquitetura Ecológica (Fonte: SEDE, 2012, p.01)........ 52

Figura 4: Custo total de um edifício comercial em 50 anos- vida útil de projeto (CEOTTO, 2008) 61 Figura 5: Possibilidade de interferência no custo total de um edifício em 50 anos (CEOTTO, 2008)

Figura 6: Exemplo de diagrama de análise do nível de integração entre disciplinas no currículo (Adaptado de EDUCATE, 2011)

Figura 7: Exemplo de gráfico de horas-aula por tipo de disciplina e etapa do curso (Adaptado de EDUCATE, 2011).

Figura 8: Modelos paradigmáticos das estruturas curriculares de ensino da Arquitetura e Urbanismo

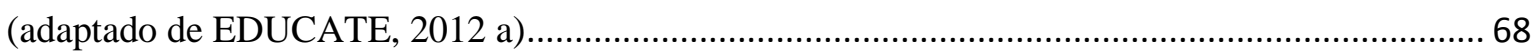

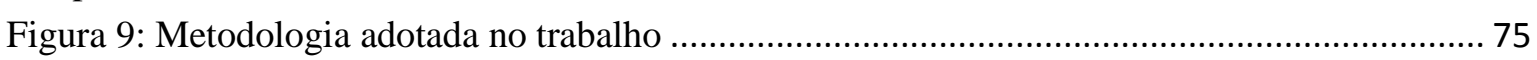

Figura 10: Estrutura do Planejamento do Ensino na Graduação .................................................... 92

Figura 11: Questionário sobre o ensino da sustentabilidade enviado aos professores das "disciplinas

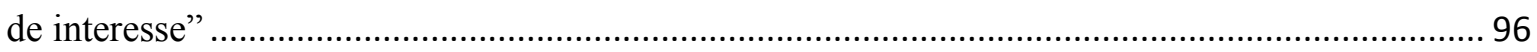

Figura 12: Legenda do diagrama de análise da integração das disciplinas nos currículos .............. 100

Figura 13: Diagrama da integração entre as disciplinas especializadas e a prática de projeto no

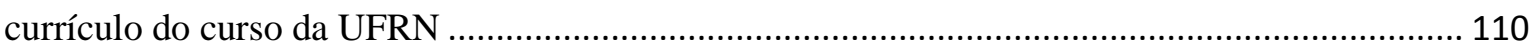

Figura 14: Carga horária da UFRN das disciplinas obrigatórias por tipo e período, em horas-aula

Figura 15: Diagrama representativo da integração entre as disciplinas especializadas e a prática de projeto no currículo do curso da UFRGS.

Figura 16: Carga horária da UFRGS das disciplinas obrigatórias por tipo e período, em horas-aula

Figura 17: Diagrama representativo da integração entre as disciplinas especializadas e a prática de projeto no currículo do curso da USP

Figura 18: Carga horária da USP das disciplinas obrigatórias por tipo e período, em horas-aula 122 Figura 19: Diagrama representativo da integração entre as disciplinas especializadas e a prática de projeto no currículo do curso da UnB

Figura 20: Carga horária da UnB das disciplinas obrigatórias por tipo e período, em horas-aula. 128 Figura 21: Carga horária das disciplinas especializadas (obrigatórias e eletivas), por tipo, por curso

Figura 22: Carga horária das disciplinas por tipo de abordagem da sustentabilidade (inclui todas disciplinas que abordam a temática), por curso

Figura 23: Nível de integração entre as disciplinas especializadas e projeto em ateliê, em

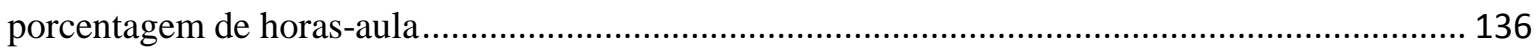

Figura 24: Recorrência de métodos de ensino nas disciplinas especializadas ............................... 138

Figura 25: Recorrência de métodos de ensino nas disciplinas de projeto ..................................... 139

Figura 26: Recorrência de critérios de avaliação nas disciplinas especializadas ............................ 140

Figura 27: Recorrência de critérios de avaliação nas disciplinas de projeto ................................... 142

Figura 28: Carga horária das disciplinas especializadas obrigatórias x carga horária das disciplinas obrigatórias com abordagem sobre a sustentabilidade (de projeto e especializadas) 


\section{LISTA DE SÍMBOLOS, NOMENCLATURAS E ABREVIAÇÕES}

ABNT- Associação Brasileira de Normas Técnicas

ANTAC - Associação Nacional de Tecnologia do Ambiente Construído

AQUA - Alta Qualidade Ambiental

BEPAC - Building Environmental Performance Assessment Criteria

BIM- Modelagem de Informações Construtivas

BREEAM - Building Research Establishment Environmental Assessment Method

CSTB - Centre Scientifique et Technique du Bâtiment

EESC - Escola de Engenharia de São Carlos

Enade - Exame Nacional de Desempenho de Estudantes

ENBA- Escola Nacional de Belas Artes

FAU - Faculdade de Arquitetura e Urbanismo

GBC - Green Building Challenge

H.a.- hora-aula

HQE - Haute Qualité Environnementale

IES - Instituição de Ensino Superior

INEP - Instituto Nacional de Estudos e Pesquisas Educacionais Anísio Teixeira

INMETRO - Instituto Nacional de Metrologia, Qualidade e Tecnologia

LEED - Leadership in Energy and Environmental Design

MEC - Ministério da Educação

PBE - Programa Brasileiro de Etiquetagem

PPG - Programa de Pós-Graduação

PPP - Projeto Político-Pedagógico

TFG - Trabalho Final de Graduação

UCPE - Universidade Católica de Pernambuco

UCS - Universidade de Caxias do Sul

UEL - Universidade Estadual de Londrina

UEP - Universidade Estadual Paulista

UFAL - Universidade Federal de Alagoas

UFBA - Universidade Federal da Bahia

UFC - Universidade Federal do Ceará

UFF - Universidade Federal Fluminense

UFJF - Universidade de Juiz de Fora

UFPE - Universidade Federal de Pernambuco

UFPI - Universidade Federal do Piauí

UFPR - Universidade Federal do Paraná

UFRGS - Universidade Federal do Rio Grande do Sul

UFRJ - Universidade Federal do Rio de Janeiro

UFRN - Universidade Federal do Rio Grande do Norte

UFSC - Universidade Federal de Santa Catarina

UFU - Universidade Federal de Uberlândia 
UFV - Universidade Federal de Viçosa

UnB - Universidade de Brasília

UNEP - United Nations Environment Programme

UNESP - Universidade Estadual Paulista

Unifor - Universidade de Fortaleza

UNIVALI - Universidade do Vale do Itajaí

UPF - Universidade de Passo Fundo

USP - Universidade de São Paulo 


\section{INTRODUÇÃO}

$\mathrm{Na}$ década de 60 inicia-se um processo de conscientização sobre as diversas e crescentes problemáticas ambientais, que culminariam no chamado novo movimento ambientalista. Neste período iniciaram-se movimentos ambientalistas motivados principalmente pela contaminação das águas e do ar em países industrializados e pela preocupação global com a precipitação nuclear, período pós-guerra (MCCORMICK, 1992). Com o passar dos anos, na década de 70, eclode a preocupação com os desequilíbrios energéticos (motivados pela crise do petróleo) e, na sequência, também emergem as discussões sobre os desequilíbrios climáticos, econômicos, dentre outros (KEELER E BURKE, 2009).

De acordo com Keeler e Burke (2009), com a intensificação das crises ambientais, observou-se que estas afetavam todas as regiões do planeta, independentemente do tamanho de suas populações e de seu nível de industrialização. A discussão ambiental passou a estar presente na maioria dos discursos de cunho internacional. Para Dusi (2006, p.21) o fato é que "o modelo de crescimento econômico vigente gerou enormes desequilíbrios ambientais, tanto nos países desenvolvidos como naqueles em desenvolvimento".

Segundo Lovelock (1979) o planeta é como um ser vivo, dotado de partes interligadas entre si que atuam para o perfeito funcionamento do todo. Se algumas destas partes não funcionarem bem, por terem sido danificadas ou esgotadas, isto se refletirá no meio ambiente de diversas formas, afetando além do homem, os ciclos normais de sobrevivência do planeta

Logo, após vários eventos de alerta ambiental mundial, surge o termo “desenvolvimento sustentável”. De acordo com o Relatório Brundtland (1987, p.28), o primeiro a conceituar o termo, "a sustentabilidade consiste em suprir as necessidades da geração presente sem, no entanto, afetar a habilidade das gerações futuras de suprir as suas". O relatório enfatizava também que as sociedades atuais necessitam, para um desenvolvimento sustentável, de justiça social, eficiência econômica e equilíbrio ambiental, condições estas que definiram as três dimensões da sustentabilidade. Posteriormente, o termo "desenvolvimento sustentável” gerou muitas definições adaptadas dentro de cada área do conhecimento. 
$\mathrm{Na}$ área da Arquitetura e Urbanismo, especificamente, as possibilidades de contribuir com a sustentabilidade permeiam as três dimensões da sustentabilidade: social, econômica e ambiental. Contudo, as maiores possibilidades de contribuição direta do arquiteto e urbanista com a sustentabilidade estão concentradas na dimensão ambiental e, como reflexo disto, esta dimensão também tem sido a mais explorada pelo mercado, em pesquisas e pelo ensino na área de Arquitetura e Urbanismo. Desta forma, explica-se brevemente o porquê do recorte desta dissertação ter focado a dimensão ambiental da sustentabilidade, bem como, a ênfase dada às áreas de conforto, materiais e conservação de energia e recursos naturais, que são as áreas que geram os maiores impactos nos espaços urbanos.

Corbella e Yannas (2003) esclarecem que, desde os primórdios, os arquitetos e urbanistas se preocuparam em proporcionar o conforto ao edifício de forma passiva. Porém, com a enorme expansão das técnicas construtivas após a II Guerra Mundial, os arquitetos foram deixando que tal atribuição fosse suplantada pelas tecnologias da engenharia.

À medida que a arquitetura moderna se reproduzia, emergia no cenário mundial de crise ambiental e energética uma nova consciência, a de que seria fundamental passar a tratar a construção de edificações e espaços urbanos de forma sustentável, devido aos grandes impactos gerados pela construção civil, como pode ser evidenciado na Agenda 21:

"As atividades do setor da construção são vitais para a concretização das metas nacionais de desenvolvimento socioeconômico: proporcionar habitação, infraestrutura e emprego. Ao mesmo tempo, por meio do esgotamento da base de recursos naturais, da degradação de zonas ecológicas frágeis, da contaminação química e do uso de materiais de construção nocivos para a saúde humana, elas podem ser uma fonte importante de danos ambientais".(UNCED - Agenda 21-Global, 1992, p.18).

Destaca-se que a implantação, manutenção e descarte de edificações é uma área de bastante expressividade no que tange aos impactos ambientais e, consequentemente, no potencial de redução destes.

A Agenda 21 for Sustainable Construction in Developing Countries (CIB/ UNEP, 2002), estimou que a indústria da construção é responsável por $40 \%$ do consumo de recursos naturais mundiais e por mais de $40 \%$ de toda a produção de resíduos. Reforçando 
a grandeza dos impactos causados pelo setor da construção civil, se considerarmos somente o consumo de energia elétrica no Brasil, estima-se que $45 \%$ do que se produz, atualmente, seja consumido na operação e manutenção de edificações e na promoção de conforto aos seus usuários (PROCEL, 2012).

Segundo Corbella e Yannas (2003), a Arquitetura Sustentável consiste em criar edifícios visando o aumento da qualidade de vida do ser humano no ambiente construído e no seu entorno, integrado com as características da vida e do clima locais, consumindo a menor quantidade de energia compatível para legar um mundo menos poluído para as futuras gerações.

Neste cenário, as escolas de Arquitetura e Urbanismo têm responsabilidade plena em aplicar e difundir conhecimento a respeito da sustentabilidade de edificações e dos espaços urbanos. Mazria (2003, p.51) entende que as escolas são capazes de instituir mudanças tão profundas na profissão que por meio dela é que podemos começar a falar de um redirecionamento da arquitetura.

Em reforço a esta ideia, fica claro em Vasconcelos et al (2006) que o ensino adequado da sustentabilidade nas escolas de Arquitetura e Urbanismo é de fundamental importância para a modificação do perfil das edificações e das cidades, já que os arquitetos e urbanistas exercem papel essencial na definição das diretrizes das construções no país.

\begin{abstract}
"Preparar as gerações futuras de profissionais para a nova linguagem que a arquitetura sustentável requer, de forma a transformar significativamente o modelo atual de cidade, é um dos desafios das escolas de arquitetura para o século XXI. Esta transformação passa obrigatoriamente por uma revisão do currículo acadêmico, de maneira a inserir conceitos de sustentabilidade nas diversas disciplinas, o que se refletirá no exercício profissional dos futuros arquitetos”.
\end{abstract}

(VASCONCELOS et al, 2006, p.3886)

Neste contexto, verifica-se a necessidade de investigar o ensino da sustentabilidade ofertado em escolas de Arquitetura e Urbanismo no Brasil pensando nas possibilidades de aprimoramento do mesmo, com destaque para a função norteadora do currículo na qualidade da formação acadêmica. 
Por fim, acredita-se que o ensino adequado da temática na graduação deverá se refletir, posteriormente, nas práticas profissionais destes alunos e contribuir com a modificação dos espaços urbanos atuais, tornando-os mais sustentáveis.

\subsection{JUSTIFICATIVA}

Corroborando com a breve explanação sobre a importância da sustentabilidade no contexto da Arquitetura e Urbanismo apresentada na introdução deste capítulo, pode-se justificar o presente trabalho baseando-nos em de três afirmativas:

\section{$1^{0}$. A sustentabilidade na atuação do Arquiteto e Urbanista corrobora com a redução dos impactos ambientais.}

É fato que o setor da Construção Civil contribui de maneira determinante na geração de impactos ambientais em todo o mundo, tanto pelo consumo expressivo de recursos naturais quanto na produção de resíduos. Desta forma, este setor também apresenta um grande potencial na redução destes impactos, se conduzido de forma sustentável.

Para fins de uma obra menos impactante ao meio ambiente é muito importante a etapa de planejamento. Ou seja, a obra pode ser pensada de forma sustentável desde as decisões preliminares até sua forma de execução, uso e manutenção. Pode-se pensar também em como será o reaproveitamento ou descarte da obra para um planejamento mais completo e sustentável. Segundo Ceotto (2008) de $80 \%$ a 100\% dos impactos ambientais são definidos durante a idealização e concepção de projeto (etapas de projeto).

O Sustainable Environmental Design Education - SEDE (2012) aponta que um Projeto Sustentável consiste nos princípios e práticas de arquitetura e paisagem que protegem a qualidade ambiental e a saúde humana, visando reduzir os impactos ambientais resultantes de alterações físicas dos edifícios e paisagens, melhorando o ciclo de vida dos investimentos naturais, humanos e financeiros nos ambientes construídos e naturais.

Desta forma, entende-se que os profissionais de Arquitetura e Urbanismo podem e devem trabalhar de forma mais consciente, tendo como uma de suas prioridades o atendimento dos quesitos de sustentabilidade pertinentes a cada projeto, colaborando assim com construções menos impactantes ao meio ambiente. 


\section{$2^{\circ}$. O ensino na graduação direciona a atuação profissional do arquiteto e urbanista.}

A atuação do arquiteto é reflexo de toda a bagagem que o mesmo adquiriu em sua formação acadêmica e, posteriormente, em sua experiência profissional, além de influências sociais, culturais, etc. Contudo, a formação acadêmica destaca-se por aportar o conhecimento teórico e técnico essencial para subsidiar o crescimento e aprimoramento do profissional de acordo com princípios correlatos à profissão. Corroborando com esta ideia e com as afirmativas apresentadas na introdução deste capítulo, complementa-se a afirmativa com a citação de Veloso:

“As escolas têm papel fundamental na formação do profissional
qualificado, cuja prática deve ser fundamentada pelo conhecimento,
uma exigência da sociedade atual, em que é imprescindível
acompanhar as constantes transformações e avanços sociais e
tecnológicos. O saber-fazer de alguns ofícios pode até ser aprendido
fora da escola, mas é nela que se produz o conhecimento, a reflexão
crítica sobre o que se faz. (VELOSO, 2008, p.01)"

Frente ao novo contexto mundial do desenvolvimento sustentável, Vasconcelos et al (2006) acreditam que o ensino da arquitetura tem papel fundamental na formação das novas gerações de profissionais, conscientes e capacitados para enfrentar as crises ambientais e que as bases de ensino das escolas de arquitetura, que pouco se renovam, impedem as cidades de acompanharem o novo contexto mundial.

De acordo com a publicação das Nações Unidas, Guidelines on Education Policy for Sustainable Built Environments (UNEP, 2010), as universidades estão numa posição privilegiada para desenvolver estratégias para a sustentabilidade através da pesquisa e do ensino.

O ensino da temática da sustentabilidade em cursos de Arquitetura e Urbanismo contribui com a conscientização do aluno sobre a importância do tema e corrobora com uma atuação profissional mais responsável.

$3^{\text {o }}$. As escolas de Arquitetura e Urbanismo necessitam incorporar a temática da sustentabilidade dentro de suas prioridades curriculares. 
Nas novas diretrizes curriculares do curso de graduação em Arquitetura e Urbanismo (MEC,2010) verifica-se que a temática da sustentabilidade já tem sua importância reconhecida e foi abordada tanto nas "ações pedagógicas" quanto no "perfil profissional". Porém, as diretrizes curriculares deixam em aberto a forma de inserção da temática da sustentabilidade nos currículos das escolas e sua aplicação fica subordinada ao projeto político pedagógico de cada uma.

Considerando esta liberdade de atuação, Leite (2011) destaca que as escolas de arquitetura estão tímidas em abraçar o tema da sustentabilidade com profundidade e amplitude, deixando-o, principalmente, para os cursos de capacitação em Certificações, ao invés de enriquecerem o tema na graduação.

O Guidelines on Education Policy for Sustainable Built Environments (UNEP, 2010) destaca que os currículos devem envolver os alunos na avaliação e planejamento sustentável, serem concebidos para fomentar laços fortes com as comunidades locais e envolver os alunos em trabalhos práticos com as comunidades. O guia ainda aponta a necessidade de:

- "Classificar, rever e auditar currículos existentes e programas de ensino $e$ treinamento/capacitação, para identificar lacunas $e$ oportunidades de aprendizagem (entre os currículos), em seguida, desenvolver novos programas para a educação da arquitetura sustentável”.(UNEP, 2010,p.32)

Destaca-se que os objetivos do presente trabalho estão em perfeita consonância com o caminho apontado por este guia para o aperfeiçoamento do ensino da sustentabilidade na Arquitetura e Urbanismo.

Corroborando com a ideia, o EDUCATE (2012), grupo formado por pesquisadores de importantes universidades europeias com o objetivo de orientar a abordagem da sustentabilidade como prioridade na formação dos arquitetos, aponta que o currículo deve promover uma abordagem da sustentabilidade integrada entre as diferentes disciplinas, entre as várias partes do curso e entre os professores que nele atuam, para o alcance das metas da sustentabilidade.

Logo, o presente trabalho justifica-se por apresentar, ao alcance dos objetivos traçados, uma série de informações sobre o ensino da sustentabilidade que vem a subsidiar 
reflexões junto às escolas de Arquitetura e Urbanismo a respeito dos seus respectivos projetos político pedagógicos, currículos e planos de ensino, conforme as experiências positivas identificadas, visando contribuir, a médio e longo prazo, numa formação acadêmica mais voltada à sustentabilidade.

Desta forma, de acordo com o evidenciado acima, levanta-se o problema a ser tratado no presente trabalho: Como abordar a temática da sustentabilidade nos cursos de Arquitetura e Urbanismo no Brasil?

\subsection{OBJETIVO GERAL}

O objetivo geral desta dissertação é fornecer subsídios para o ensino da sustentabilidade em cursos de Arquitetura e Urbanismo no Brasil, a partir de seus projetos político pedagógicos, currículos e planos de ensino.

O impacto seria o aprimoramento curricular dos cursos de Arquitetura e Urbanismo, objetivando uma maior conscientização e melhor apreensão dos conteúdos, competências e habilidades relacionados à sustentabilidade durante a formação acadêmica do arquiteto/urbanista com vistas à perpetuação de ações permeadas deste conhecimento na atuação do profissional formado.

\subsection{OBJETIVOS ESPECÍFICOS}

Como objetivos específicos foram definidos:

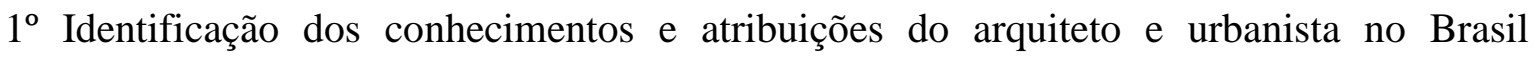
relacionados à sustentabilidade a partir da legislação profissional e documentos institucionais;

$2^{\circ}$ Levantamento de legislações e certificações nacionais e internacionais voltadas à sustentabilidade no âmbito da Arquitetura e Urbanismo;

$3^{\text {o }}$ Elaboração de breve panorama do ensino da sustentabilidade de cursos de Arquitetura e Urbanismo do Brasil e do exterior.

$4^{\circ}$ Identificação dos cursos de Arquitetura e Urbanismo que mais se destacaram no ensino da sustentabilidade no Brasil. 
Logo, no intuito de alcançar os objetivos traçados, a presente dissertação de mestrado foi estruturada em seis capítulos.

O primeiro capítulo (Introdução) aborda a introdução ao tema e a problemática, justificativa, objetivos geral e específicos da dissertação.

O segundo capítulo (A sustentabilidade na Arquitetura e Urbanismo) trata de revisão bibliográfica pertinente ao trabalho e está dividido em três seções. A primeira seção (As dimensões da sustentabilidade) busca identificar a sustentabilidade e suas diversas dimensões e delimita o recorte da sustentabilidade que foi considerado neste trabalho. A segunda seção ( $O$ contexto da sustentabilidade na Arquitetura e Urbanismo) busca conceituar a sustentabilidade a partir do recorte do trabalho e por meio da visão de vários autores. A terceira seção (Legislações e Certificações) procura apresentar as legislações e certificações de maior relevância no Brasil e exterior considerando o recorte do trabalho.

O terceiro capítulo (O ensino da sustentabilidade na Arquitetura e Urbanismo) também trata de revisão bibliográfica pertinente ao trabalho e está dividido em cinco seções. A primeira seção (Perspectiva histórica) apresenta breve histórico do surgimento das escolas de Arquitetura e Urbanismo no Brasil e no mundo. A segunda seção (Perspectiva internacional) apresenta características atuais do ensino da sustentabilidade em escolas de Arquitetura e Urbanismo no exterior. A terceira seção (Perspectiva no Brasil) apresenta características do ensino da sustentabilidade em escolas de Arquitetura e Urbanismo no Brasil e analisa a legislação e documentos institucionais que definem os conhecimentos e atribuições delegados ao arquiteto e urbanista no país. A quarta seção (A integração entre teoria e prática) trata da importância da integração entre teoria e prática para a qualidade do ensino da sustentabilidade. A quinta e última seção (Avaliação Curricular: projeto EDUCATE) apresenta, de forma resumida, o método utilizado pelo EDUCATE para analisar o ensino da sustentabilidade em cursos de Arquitetura e Urbanismo de diversos países, modelo este que serviu como principal referência ao método de análise aplicado nesta dissertação de mestrado.

O quarto capítulo (Método) apresenta o método desenvolvido para alcance dos objetivos traçados detalhando os procedimentos de cada etapa do trabalho desenvolvido e está dividido em duas seções. A primeira (Seleção dos cursos) apresenta o método de 
identificação dos cursos de Arquitetura e Urbanismo que apresentaram os melhores resultados no ensino da sustentabilidade considerando o Enade 2011, Bienal José Miguel Aroztegui e Bienal de Sustentabilidade José Lutzenberger. A segunda seção (Levantamento e sistematização dos dados) apresenta o método de levantamento dos dados dos cursos previamente selecionados, definição dos critérios de análise e explica como se deu a sistematização das informações coletadas.

O quinto capítulo (Resultados e discussões) apresenta os resultados dos levantamentos e análises realizados e discussões pertinentes e está dividido em três seções. A primeira seção (Seleção dos cursos) apresenta o cruzamento de dados com identificação dos cursos que mais se destacaram no ensino da sustentabilidade, considerando os eventos analisados. A segunda seção (Resultados) apresenta o resultado das análises desenvolvidas a partir dos projetos político pedagógicos, currículos e planos de ensino de cada um dos cursos selecionados e comparativamente entre os mesmos. A terceira seção (Discussões) discute sobre as principais características identificadas nos currículos analisados e apresenta subsídios para a abordagem da sustentabilidade no ensino da graduação em Arquitetura e Urbanismo.

O sexto e último capítulo (Considerações finais) apresenta as principais conclusões das análises e as considerações finais do trabalho e está dividido em duas seções. A primeira (Limitações da pesquisa) que apresenta as dificuldades encontradas no desenvolvimento do mesmo e a segunda seção (Sugestões para trabalhos futuros) com identificação de melhorias para a linha de pesquisa e sugestões para trabalhos futuros. 


\section{A SUSTENTABILIDADE NA ARQUITETURA E}

\section{URBANISMO}

O presente capítulo, a partir de publicações históricas, técnicas e científicas, busca identificar na história indícios de sustentabilidade na atuação do arquiteto e urbanista sob diversos enfoques e terminologias diferenciadas. Na sequência, procura-se levar a uma melhor compreensão das dimensões da sustentabilidade na Arquitetura e Urbanismo, além de tentar conceituar e delimitar o recorte da sustentabilidade na Arquitetura e Urbanismo que foi considerado para este trabalho. Por fim, são destacadas as legislações e certificações internacionais e nacionais voltadas à promoção da sustentabilidade no contexto da Arquitetura e do Urbanismo, buscando demonstrar a relevância do tema e seus impactos no meio acadêmico.

Inicialmente, no intuito de conceituar sustentabilidade, verifica-se no dicionário da língua portuguesa que a palavra sustentabilidade é derivada do adjetivo sustentável, que significa: "o que se pode sustentar". O verbo sustentar, por sua vez, significa: "resistir a, impedir a ruína ou queda de; conservar a mesma posição, suster-se, equilibrar-se, manterse, etc.” (FERREIRA, 1988).

A seguir, deve-se destacar o importante documento: "Our Common Future", conhecido também como "Relatório Brundtland" (BRUNDTLAND, 1987), elaborado pela Comissão Mundial sobre o Meio Ambiente e Desenvolvimento da Organização das Nações Unidas, que tornou conhecido o termo "desenvolvimento sustentável”. Neste, o termo "sustentável" qualifica um modelo de desenvolvimento capaz de suprir as necessidades da geração presente sem, no entanto, afetar a habilidade das gerações futuras de suprir as suas.

No contexto da arquitetura e do urbanismo, apesar do termo "sustentabilidade" ser relativamente novo, identifica-se que alguns temas tratados por esta temática não são novidade nesta área. Verifica-se que ações de cunho sustentável, principalmente ligadas à sua dimensão ambiental e perpassando pelas áreas de conforto, materiais e conservação de energia e recursos naturais, estão diretamente ligadas aos princípios fundamentais dessa profissão ao longo da história.

Os autores Corbella e Yannas (2003) afirmam que desde os primórdios da humanidade o homem buscou proteger-se das intempéries e do ambiente hostil, procurando em suas 
construções, filtrar a quantidade de calor, frio, umidade, secura, dentre outros fatores externos de forma passiva, tornando suas construções mais duradouras. São exemplos destes a arquitetura grega, romana, indígena, etc. Da mesma forma aconteceu no planejamento urbano, por exemplo, a América Espanhola, desde os tempos coloniais, seguia regras que consideravam, além de aspectos de defesa, a topografia, a incidência solar, os ventos, as chuvas, dentre outros fatores que objetivavam uma habitabilidade mais confortável e duradoura.

Reforçando a ideia acima, Segawa (2003) afirma que é possível identificar ideais para propiciar o conforto ambiental na arquitetura desde a Antiguidade até o Iluminismo, no contexto da expansão dos horizontes geográficos e climáticos no início da Era Moderna, para posteriormente, no final do século 19 se evidenciar como matéria cientificamente sistematizada.

É importante observar que um dos principais aspectos a serem considerados para propiciar a sustentabilidade na Arquitetura e Urbanismo é projetar atentando aos parâmetros de conforto ambiental (climáticos, térmicos, acústicos, luminosos, dentre outros), sendo que tais parâmetros devem estar de acordo com as características sociais e climáticas do local. O objetivo seria minimizar, além dos impactos do meio ambiente sobre a edificação, os impactos desta sobre o meio ambiente, propiciando o conforto de forma passiva e, consequentemente, um menor consumo energético e de outros recursos naturais.

Segundo Dumke (2002) o arquiteto, escultor, pintor e músico da Renascença, Alberti, no século $\mathrm{XV}$, já considerava a avaliação e a seleção do lugar, do microclima, dos materiais apropriados, e procurava oferecer aos ambientes proteção do sol e dos ventos para propiciar o conforto térmico em suas construções. Contudo, nos séculos XVII e XVIII, os arquitetos deixaram de se preocupar com as diferenciações do clima passando a utilizar construções massivas com pequenas janelas, uma tecnologia que permitia um desempenho térmico razoável das edificações tanto em climas com altas amplitudes térmicas, desta forma cria-se uma uniformidade com características idênticas para obras localizadas em regiões de climas diferentes (DUMKE, 2002, p. 42).

Ainda segundo Dumke (2002), no século XX, devido à organização do trabalho em recintos fechados, surgiu a necessidade de aplicação de conceitos de higiene e conforto, onde destacaram-se a busca pela insolação das fachadas, pelo calor, pela iluminação e 
ventilação naturais. Segawa (2003) destaca Victor da Silva Freire, em 1918, (século XX) como escritor de preciosa memória sobre a salubridade, o que seria posteriormente transformado em códigos sanitários (termos utilizados para tratar de alguns dos aspectos hoje delimitados dentro dos conhecimentos de conforto ambiental) e orientados cientificamente:

"(a) Cubação qualquer - desde que o ar possa penetrar em movimento e "circular" pelo interior da casa entre a frente e o fundo;

(b) Pé-direito qualquer - determinado de preferência pela iluminação, admitindo-se que se lê perfeitamente no fundo de um cômodo distante da janela o dobro da altura (com a condição que a rua ou a área correspondentes sejam claras);

(c) Área ampla proporcionada à altura das paredes que a contornem, a fim de que o ar não fique "estagnado" mas a percorra sem cessar de um topo a outro."

(FREIRE, 1918 apud SEGAWA, 2003, p.40)

Segawa (2003) mostra indícios também de que a insolação adquiria importância, no III Congresso Internacional de Saneamento e Salubridade da Habitação em Dresden, 1911:

"A importância da ação direta dos raios do sol é fundamental na construção das cidades. O espectro solar revelou-nos os raios ultravioletas como sendo microbicidas por excelência. Todos os micróbios sem exceção são aniquilados pelos raios do sol.

Ora, é incontestável que o sol tem sido esquecido nos nossos planos de cidades; é esse um ponto fundamental, que necessita reforma profunda nos nossos hábitos."

(FREIRE, 1916 apud SEGAWA, 2003, p. 41)

É importante destacar que no início do século XX, correspondente ao período das citações acima, o aprimoramento dos projetos no sentido de propiciar uma maior salubridade e saneamento das edificações, por meio de ventilação e insolação mais efetivas, teve como importante consequência aumentar a durabilidade da edificação tanto no sentido funcional quanto estrutural e material, já que a organização dos ambientes passou a ser melhor planejada e passou-se a priorizar materiais mais resistentes à proliferação de microrganismos e minimizaram-se as condições ambientais nocivas que 
levavam à decomposição precoce da construção. Destaca-se que a durabilidade também é um aspecto importante para caracterização de uma arquitetura ou urbanismo sustentáveis.

Em contrapartida, no período pós II Gerra Mundial (1939-1945), com o advento de maiores facilidades logísticas, Corbella e Yannas (2003) destacam que o arquiteto passou a introduzir materiais mais elaborados, algumas vezes vindos de outras regiões, mesmo distantes, fugindo da consequência natural de propiciar sustentabilidade a partir das habilidades projetuais dos arquitetos (arquitetura passiva, regional, etc.), Também com o passar dos anos e expansão das técnicas construtivas, os arquitetos foram deixando algumas de suas atribuições serem suplantadas pela tecnologia dos engenheiros que era capaz de possibilitar o conforto através de condicionamento ambiental ativo, iluminação artificial, dentre outras facilidades. Neste cenário, destaca-se que o aumento do consumo de energia não foi levado em conta por seu custo irrisório e pela falta de consciência da poluição gerada com o uso dessa energia.

No urbanismo, segundo Dumke (2002), no século XX as facilidades oferecidas pelos novos materiais e técnicas contribuíram para a construção de edifícios em altura e a escala começou a interferir, principalmente nas cidades, no sentido dos ventos, no sombreamento ao redor da base dos edifícios, alterando o microclima local. Neste período, em contraposição a esta tendência, arquitetos como Frank Lloyd Wright e Le Corbusier são mencionados por considerarem em seus projetos alguns aspectos que contribuem para a melhoria da qualidade do ambiente, no sentido do conforto e da sustentabilidade, considerando ventilação e iluminação naturais, integração com o entorno, busca pela melhor orientação solar, etc.

Sobreira (2008), por sua vez, apesar de reconhecer que não é nova a preocupação com a sustentabilidade no contexto da Arquitetura e Urbanismo, enfatiza que deve-se observar o grande destaque que vem sendo dado nos últimos anos. A temática da sustentabilidade vem ganhando maior espaço, seja pela conscientização de alguns grupos da sociedade sobre a sua real necessidade, seja pelo marketing comercial que a temática agrega, levando à valorização econômica de uma grande variedade de produtos do mercado.

Na visão de Avezum (2007) o grande e rápido crescimento das cidades juntamente com a arquitetura produzida ao longo do século XX, era de Indústria e Tecnologia, degradaram o meio ambiente e levaram a grandes problemas ambientais, como o 
aquecimento global e mudanças climáticas. Logo, o início do presente século (XXI) tem sido marcado pela intensificação de catástrofes naturais e já identifica-se que a construção e funcionamento de edifícios são responsáveis por grande parte destes impactos. Desta forma, neste século XXI cabe aos arquitetos e urbanistas e outros profissionais da área a tarefa de tentar reverter este quadro, criando ambientes mais sustentáveis. Segundo o Avezum (2007) são necessários tanto a conscientização ecológica quanto o desenvolvimento tecnológico para a viabilização de projetos sustentáveis.

Desta forma, é neste cenário que acredita-se no surgimento de uma nova iconografia arquitetônica para o século XXI, de cunho sustentável e tecnológico.

\subsection{AS DIMENSÕES DA SUSTENTABILIDADE}

O relatório Brundtland (1987), documento de repercussão internacional, já enfatizava que as sociedades necessitavam, para se caracterizar como sustentáveis, de três fatores: justiça social, eficiência econômica e equilíbrio ambiental. Estes fatores estão relacionados com três dimensões da sustentabilidade: social, econômica e ambiental.

Apesar de comumente relacionada a aspectos ambientais, a abordagem dada à sustentabilidade pela Agenda 21 (CIB/ UNEP, 2002) apresenta esta temática de forma mais completa, como um princípio mais amplo. Sachs (1993, p.25), um dos autores da agenda 21, enfatiza que é preciso ter uma visão holística da sustentabilidade e a subdivide em cinco dimensões para uma melhor compreensão e apreensão da mesma, como pode ser verificado no Quadro 1 abaixo: 
Quadro 1: Dimensões da sustentabilidade (adaptado de Sachs,1993, p.25)

\begin{tabular}{ll|}
$\begin{array}{l}\text { 1.Sustentabilidade } \\
\text { econômica }\end{array}$ & $\begin{array}{l}\text { Preconiza que a eficiência econômica deva ser medida em termos } \\
\text { macro-sociais e não através de critérios microeconômicos de } \\
\text { rentabilidade empresarial, além de preconizar a diminuição da } \\
\text { dependência externa. }\end{array}$ \\
\hline $\begin{array}{l}\text { 2.Sustentabilidade } \\
\text { Social }\end{array}$ & $\begin{array}{l}\text { Preconiza uma civilização com maior equidade na distribuição de } \\
\text { renda e bens, reduzindo a distância entre as camadas sociais. }\end{array}$ \\
\hline $\begin{array}{l}\text { 3.Sustentabilidade } \\
\text { Geográfica ou } \\
\text { Espacial }\end{array}$ & $\begin{array}{l}\text { Propõe uma configuração rural-urbana mais equilibrada, com a } \\
\text { redeção de ecossistemas frágeis, a criação de reservas para proteção } \\
\text { da biodiversidade e a prática da agricultura e agro silvicultura com } \\
\text { técnicas regenerativas e em escalas menores, ou seja, propõe o uso } \\
\text { do solo planejado. }\end{array}$ \\
\hline $\begin{array}{l}\text { 4.Sustentabilidade } \\
\text { Cultural }\end{array}$ & $\begin{array}{l}\text { Valoriza as raízes endógenas, com soluções que contemplem as } \\
\text { especificidades locais do ecossistema, com transformações } \\
\text { sintonizadas com um contexto que permita a continuidade cultural. }\end{array}$ \\
\hline $\begin{array}{l}\text { 5.Sustentabilidade através da racionalização do aporte de recursos, com a } \\
\text { Ecológica }\end{array}$ & $\begin{array}{l}\text { Obtimitação daqueles esgotáveis ou danosos ao meio ambiente; redução } \\
\text { do volume de resíduos, por meio da conservação de energia e práticas } \\
\text { de reciclagem, pesquisas em tecnologias ecologicamente mais } \\
\text { adequadas e implementação de políticas de proteção ambiental. }\end{array}$ \\
\hline
\end{tabular}

De acordo com Sachs (1993, p.25) o planejamento sustentável ideal deve levar em conta o alcance das cinco dimensões da sustentabilidade apresentadas no quadro acima. $\mathrm{Ou}$ seja, o projeto de Arquitetura e Urbanismo, também deve estar atendo às várias dimensões da sustentabilidade.

Destaca-se, contudo, que as dimensões da sustentabilidade também costumam apresentar variações em análises realizadas por diferentes autores, em diferentes áreas do conhecimento e, também, quando da abordagem de temas mais específicos. É comum encontrar, por exemplo, a dimensão política, a religiosa e a territorial, que podem ser consideradas como desmembramentos mais detalhados da dimensão social, cultural e geográfica, respectivamente. E, se considerarmos classificações que sejam focadas em áreas mais específicas, podemos identificar inclusive novas dimensões, como no caso da Arquitetura e Urbanismo em que alguns autores se referem à dimensão estética, como o International Living Building Institute (LIVING BUILDING CHALLENGE, 2010). 
Pode ser observado no trabalho do International Living Building Institute (LIVING BUILDING CHALLENGE, 2010), que é mais específico ao apresentar caminhos para a promoção da sustentabilidade na área da construção civil, as várias dimensões consideradas por meio das pétalas para a sustentabilidade, conforme Quadro 2:

Quadro 2: Pétalas para a sustentabilidade (Living Building Challenge, 2010)

\begin{tabular}{|c|c|c|}
\hline 1. Lugar & $\begin{array}{l}\text { Restabelecer } \\
\text { convivência saudável } \\
\text { com a natureza }\end{array}$ & $\begin{array}{l}\text { Ressaltar a importância da proteção do lugar e a } \\
\text { preocupação com a implantação, articulados com } \\
\text { a aceitação do usuário. Incentivar comunidades } \\
\text { preocupadas, primeiramente com o usuário e, } \\
\text { posteriormente, com o elemento construído. }\end{array}$ \\
\hline 2. Água & $\begin{array}{l}\text { Proposição de } \\
\text { tecnologia } \\
\text { independente para a } \\
\text { obtenção, uso e reuso }\end{array}$ & $\begin{array}{l}\text { Reavaliar o uso de água e redefinir alternativas } \\
\text { para o uso correto e reuso. }\end{array}$ \\
\hline 3. Energia & $\begin{array}{l}\text { Considerar apenas o } \\
\text { uso da energia limpa }\end{array}$ & $\begin{array}{l}\text { Utilizar exclusivamente formas de energia } \\
\text { renováveis, com funcionamento livre de poluição, } \\
\text { tornando a edificação autônoma na geração e } \\
\text { consumo de energia. }\end{array}$ \\
\hline 4. Saúde & $\begin{array}{l}\text { Espaços que } \\
\text { proporcionem a saúde } \\
\text { psicológica e o bem- } \\
\text { estar }\end{array}$ & $\begin{array}{l}\text { Focar em diretrizes projetuais que possibilitem } \\
\text { espaços saudáveis e proporcionem o bem-estar } \\
\text { dos usuários. Espaços estes que minimizem o } \\
\text { desperdício e o transformem em ambiente } \\
\text { nutritivo, produtivo e saudável. }\end{array}$ \\
\hline 5. Materiais & $\begin{array}{l}\text { Produtos com ciclo de } \\
\text { vida definido }\end{array}$ & $\begin{array}{l}\text { Propor a utilização de materiais com conceitos } \\
\text { verde e socialmente justos. Deve-se prever um } \\
\text { plano de manejo e, conservação, que explique } \\
\text { como o projeto otimizará os materiais, em cada } \\
\text { uma das etapas da construção. }\end{array}$ \\
\hline 6. Equidade & $\begin{array}{l}\text { Apoiar uma solução } \\
\text { justa, equitativa para o } \\
\text { mundo }\end{array}$ & $\begin{array}{l}\text { A equidade social correlaciona os impactos do } \\
\text { projeto e do desenvolvimento para promover um } \\
\text { verdadeiro senso de comunidade. Uma sociedade } \\
\text { que congregue a todos os setores da humanidade } \\
\text { e permite a dignidade da igualdade de acesso. }\end{array}$ \\
\hline 7. Estética & $\begin{array}{l}\text { O projeto como objeto } \\
\text { que cria uma mudança } \\
\text { transformadora }\end{array}$ & $\begin{array}{l}\text { A estética, como elemento que reconhece a } \\
\text { necessidade de beleza, como um precursor para o } \\
\text { cuidado de preservar, conservar e servir o bem } \\
\text { maior. }\end{array}$ \\
\hline
\end{tabular}

As pétalas para a sustentabilidade apresentadas no quadro acima são um exemplo de reformulação das dimensões da sustentabilidade de Sachs para melhor inseri-las ao contexto da Construção Civil, área geradora de grandes impactos e que está intimamente ligada à Arquitetura e Urbanismo. Segundo a Agenda 21 for Sustainable Construction in 
Developing Countries (CIB/ UNEP, 2002), estima-se que a indústria da construção é responsável por $40 \%$ do consumo de recursos naturais mundiais e por mais de $40 \%$ de toda produção de resíduos, não tendo sido encontrados dados mais atualizados. Contudo, para reforçar os grandes impactos causados pelo setor da construção civil, se considerarmos somente o consumo de energia elétrica no Brasil, estima-se que $45 \%$ do que se produz, atualmente, seja consumido na operação e manutenção de edificações e na promoção de conforto aos seus usuários (PROCEL, 2012).

Blumenschein (2004) afirma que uma dada construção gera uma gama imensa de impactos em cada um dos componentes da Cadeia Produtiva da Indústria da Construção CPIC, conforme demonstra a Figura 1.

\begin{tabular}{|c|}
\hline $\begin{array}{l}\text { CADEIA DE } \\
\text { SUPRIMENTOS }\end{array}$ \\
\hline Indústria Cimento \\
\hline $\begin{array}{c}\text { Indústria Cerâmica } \\
\text { Vermelha/ } \\
\text { Revestimentos }\end{array}$ \\
\hline $\begin{array}{c}\text { Indústria Esquadrias/ } \\
\text { Madeiras }\end{array}$ \\
\hline $\begin{array}{c}\text { Indústria Material } \\
\text { Elétrico }\end{array}$ \\
\hline Indústria Siderúrgica \\
\hline $\begin{array}{l}\text { Indústria Metal } \\
\text { Mecânica }\end{array}$ \\
\hline Indústria Química \\
\hline $\begin{array}{c}\text { Indústria Extrativa/ } \\
\text { Mineral }\end{array}$ \\
\hline Serviços e Equipamentos \\
\hline
\end{tabular}
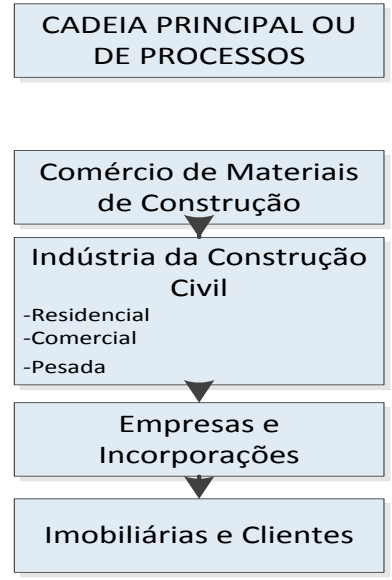
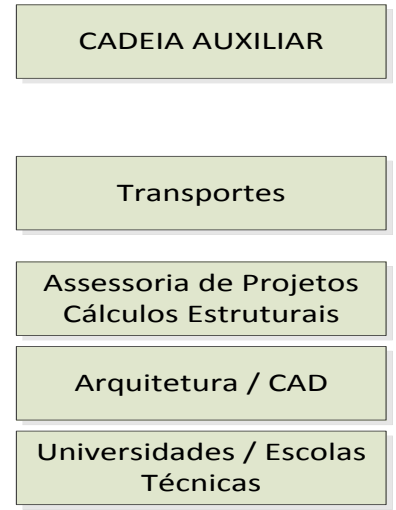

Figura 1: Cadeia Produtiva da Indústria da Construção- CPIC (Adaptado de Blumenschein, 2004, p.45)

Ainda, segundo Blumenschein (2004), os impactos de uma dada construção acontecem desde as etapas de ocupação de terras e extração de matéria-prima até a disposição de resíduos do processo construtivo, conforme observa-se no diagrama exposto na Figura 2. 

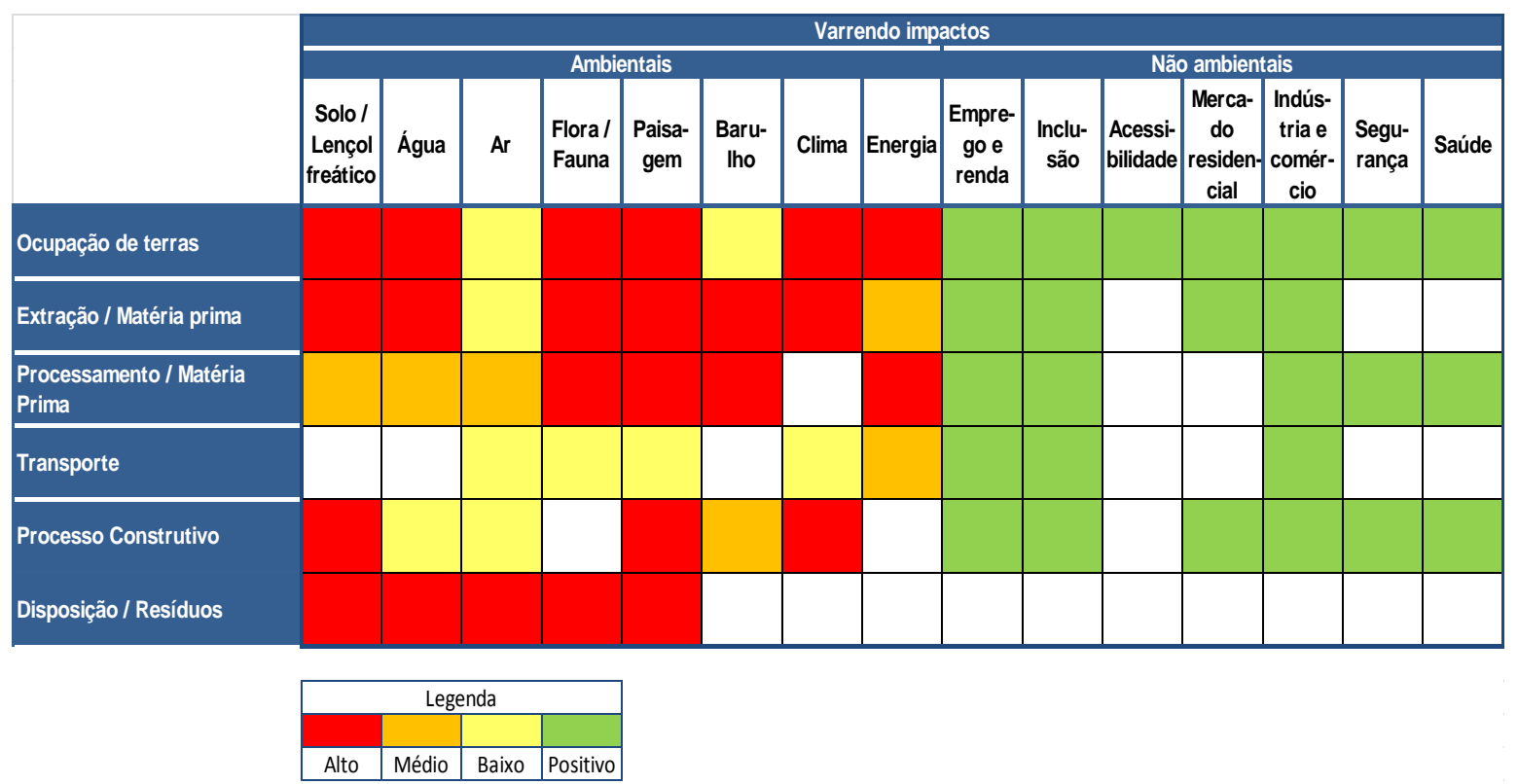

Figura 2: Varrendo impactos (adaptado de Blumenschein, 2004, p.48)

Conforme pode ser observado nas Figuras 01 e 02 os impactos da indústria da construção são bastante amplos e podem ser de cunho ambiental ou não, por isso torna-se necessário ter uma visão sistêmica do todo para pensar em intervenções voltadas à promoção da sustentabilidade.

Ainda a respeito da visão holística que se deve ter para a promoção da sustentabilidade, Silva et al (2003) destacam que a dimensão "ambiental" acaba sendo a mais explorada nos países desenvolvidos. Uma das justificativas para o fato é que nesses países a sociedade encontrou um nível de qualidade de vida, igualdade social e distribuição de riqueza sem comparação com países em desenvolvimento. Consequentemente, a agenda desses países em relação à sustentabilidade tem sido tão centrada na dimensão ambiental.

A dimensão ambiental da sustentabilidade é um princípio essencial e há muito vem influenciando na atuação do arquiteto, contudo, é importante destacar que a plenitude da sustentabilidade, principalmente em países em desenvolvimento incluindo o Brasil, deve primar também pelas dimensões social e econômica (e outras mais, variando de acordo com a referência bibliográfica) como focos também muito importantes para a promoção da sustentabilidade na Arquitetura e Urbanismo.

Por fim, mesmo reconhecendo as diversas referências utilizadas nesta revisão bibliográfica como diretamente atuantes para propiciar a sustentabilidade de edificações e 
do espaço urbano, foi decidido considerar a sustentabilidade, para critérios de análise desta dissertação, a partir da delimitação utilizada pelo grupo EDUCATE, principal referência deste trabalho para as análises realizadas, conforme Quadro 3.

Quadro 3: Questões e princípios da sustentabilidade na Arquitetura e Urbanismo

(Adaptado de EDUCATE, 2011)

\begin{tabular}{|c|c|c|}
\hline \multicolumn{3}{|c|}{ QUESTÕES E PRINCÍPIOS } \\
\hline CAMPOS & CATEGORIAS & GRUPOS \\
\hline 1. Desafios globais & a. Desafio ambiental & Mudanças Climáticas \\
\hline \multirow{5}{*}{$\begin{array}{l}\text { 2. Clima, Conforto e } \\
\text { Energia }\end{array}$} & b. Clima e Conforto & $\begin{array}{l}\text { Clima e Tempo } \\
\text { Conforto térmico } \\
\text { Conforto visual } \\
\text { Qualidade do ar interior } \\
\text { Tipologia das edificações } \\
\text { Espacos externos }\end{array}$ \\
\hline & $\begin{array}{l}\text { C. Aquecimento } \\
\text { Resfriamento }\end{array}$ & $\begin{array}{l}\text { Ambiente térmico } \\
\text { Psicrometria } \\
\text { Desempenho térmico das edificações } \\
\text { Transferência de calor } \\
\text { Desempenho dinâmico das edificações } \\
\text { Controle de Umidade } \\
\text { Princípios de arquitetura passiva } \\
\text { Sistemas de arquitetura passiva } \\
\text { Sistemas de arquitetura ativa }\end{array}$ \\
\hline & d. Ventilação & $\begin{array}{l}\text { Ventilação natural } \\
\text { Ventilação mecânica }\end{array}$ \\
\hline & e. Iluminação & $\begin{array}{l}\text { Física da luz } \\
\text { Iluminação natural } \\
\text { Iluminação artificial }\end{array}$ \\
\hline & f. Acústica & $\begin{array}{l}\text { Acústica em projeto } \\
\text { Acústica dos materiais } \\
\text { O processo de ressonância }\end{array}$ \\
\hline 3. Qualidade de vida & g. Qualidade urbana & $\begin{array}{l}\text { Planejamento urbano ecológico } \\
\text { Meio ambiente, Sociedade e Economia }\end{array}$ \\
\hline \multirow[b]{2}{*}{ 4. Impactos e Recursos } & h. Pegada ecológica & Impactos ambientais \\
\hline & $\begin{array}{l}\text { i. Gestão de recursos e } \\
\text { resíduos }\end{array}$ & $\begin{array}{l}\text { Ciclos de produção } \\
\text { Gestão da água } \\
\text { Gestão de resíduos } \\
\text { Fontes renováveis de energia }\end{array}$ \\
\hline $\begin{array}{l}\text { 5. Desenvolvimento } \\
\text { Urbano e Arquitetônico }\end{array}$ & $\begin{array}{l}\text { j. Edificações } \\
\text { Cidades }\end{array}$ & Uso da energia \\
\hline
\end{tabular}

Destaca-se que o recorte dado pelo EDUCATE para a análise do ensino da sustentabilidade, apesar de englobar temáticas que envolvem as três dimensões da sustentabilidade (social, econômica e ambiental - a partir do Relatório Brundtland), apresenta maior ênfase à dimensão ambiental. Logo, este trabalho teve suas análises 
realizadas com foco na sustentabilidade ambiental e as temáticas delimitadores da mesma estão elencadas no Quadro 3, elaborado pelo EDUCATE.

\subsection{O CONTEXTO DA SUSTENTABILIDADE AMBIENTAL NA ARQUITETURA E URBANISMO}

A partir do relatório Brundtland (1987) intensificaram-se as referências ao termo sustentabilidade / sustentável. Edwards (2008) observa, contudo, que o termo "sustentabilidade", gerou definições conseguintes, adaptadas dentro de cada área do conhecimento. Desta forma, apresentamos a seguir definições de vários autores para a sustentabilidade aplicada no contexto da Arquitetura e Urbanismo. Destaca-se que as definições consideraram o recorte definido para a presente dissertação que tem como foco a dimensão ambiental da sustentabilidade, com destaque para as áreas de conforto, materiais e conservação de energia e recursos naturais.

À princípio, Edwards (2008, p.21) apresenta duas definições, sendo que a primeira explica o projeto sustentável como a "criação de edificações eficientes do ponto de vista energético, saudáveis, confortáveis, de uso flexível e projetadas para terem uma longa vida útil" - definição do escritório Foster`s and Partners; e a segunda define a arquitetura sustentável como a "criação e gestão de edifícios saudáveis baseados em princípios ecológicos e no uso eficiente dos recursos", definição do BSRIA - Building Services Research and Information Association.

Por sua vez, o Sustainable Environmental Design Education - SEDE (2012) aponta, com destaque para o aspecto ambiental da sustentabilidade, que o "Projeto Ambiental Sustentável" consiste nos princípios e práticas de arquitetura e paisagem que protegem a qualidade ambiental e a saúde humana, visando reduzir os impactos ambientais resultantes de alterações físicas aos edifícios e paisagens, e melhorar o ciclo de vida dos investimentos naturais, humanos e financeiros nos ambientes construídos e naturais.

Corbella e Yannas, por sua vez, também apresentam um conceito para arquitetura sustentável:

"A arquitetura sustentável é a continuidade mais natural da 
totalidade do meio ambiente, de forma a torná-lo parte de um conjunto maior. É a arquitetura que quer criar prédios objetivando o aumento da qualidade de vida do ser humano no ambiente construído e no seu entorno, integrando as características da vida e do clima locais, consumindo a menor quantidade de energia compatível com o conforto ambiental, para legar um mundo menos poluído para as próximas gerações".

(CORBELLA E YANNAS, 2003, p.17)

Segundo Keeler e Burke (2009, p.50) a maioria dos arquitetos concorda que, para ser sustentável, uma edificação precisa solucionar mais do que um problema ambiental e, ainda que não possa solucionar todos os problemas, a edificação sustentável tem as seguintes metas:

“- tratar das questões de demolição no terreno e de resíduos da construção, bem como dos resíduos gerados pelos seus usuários,

- buscar a eficiência na utilização dos recursos,

- buscar a conservação de energia e projetar visando ao consumo eficiente de energia na alimentação de sistemas de calefação, refrigeração, iluminação e força. Já que a construção de edificações está entre os principais emissores de dióxido de carbono, (...)

- oferecer um ambiente interno "saudável".

(KEELER E BURKE, 2006, p.50)

Já Gonçalves e Duarte (2006) apontaram metas bem mais específicas, delimitadas por um recorte dentro da sustentabilidade voltada ao desempenho ambiental, o conforto e à eficiência energética. As autoras separaram as metas em dois grupos, sendo o primeiro dirigido ao projeto arquitetônico, que deve considerar o estudo dos seguintes itens:

“(a) orientação solar e dos ventos;

(b) forma arquitetônica, arranjos espaciais, zoneamento dos usos internos do edifício e geometria dos espaços internos;

(c) características, condicionantes ambientais (vegetação, corpos d'água, ruído, etc.) e tratamento do entorno imediato;

(d) materiais da estrutura, das vedações internas e externas, considerando desempenho térmico e cores; 
(e) tratamento de fachadas e coberturas, de acordo com a necessidade de proteção solar;

(f) áreas envidraçadas e de abertura, considerando a proporção quanto à área de envoltória, o posicionamento na fachada e o tipo do fechamento, seja ele vazado, transparente ou translúcido;

(g) detalhamento das proteções solares considerando tipo e dimensionamento; $e$

(h) detalhamento das esquadrias."

(GONÇALVES E DUARTE, 2006, p.53)

O segundo grupo é relativo às metas para espaços urbanos. Este deve considerar o estudo dos seguintes itens:

“(a) preservação e liberação de áreas naturais pelos efeitos e vantagens da compacidade urbana;

(b) proximidade, diversidade e uso misto (socialização do espaço público);

(c) maior eficiência energética (e menor poluição) pelo sistema de transporte;

(d) microclimas urbanos mais favoráveis ao uso do espaço público e ao desempenho ambiental das construções;

(e) edificios ambientalmente conscientes;

(f) consumo consciente dos recursos em geral; $e$

(g) reuso e reciclagem (diminuição do impacto ambiental proveniente da geração de resíduos em geral".

(GONÇALVES E DUARTE, 2006, p.63)

Para as autoras, considerar os aspectos citados quando da concepção de projetos arquitetônicos e urbanísticos, é essencial para considerá-los sustentáveis.

Segundo o EDUCATE (2011), a arquitetura deve ser formada por uma ética global que combina os princípios técnicos com a necessidade de garantir o conforto das pessoas e qualidade de vida, integração ambiental de forma consistente com conhecimento, compreensão e habilidade dentro de um projeto com discurso exploratório e criativo. 
Verifica-se, portanto, que existem inúmeras definições elaboradas na tentativa de caracterizar melhor a Arquitetura e Urbanismo sustentáveis. Além disso, verifica-se também que, usualmente, é dado maior enfoque aos aspectos ambientais da sustentabilidade. Contudo, observa-se que as definições existentes são, em sua maioria, extraídas de uma visão sistêmica ampla que é apresentada ora de forma mais superficial ou parcial, ora de forma mais completa, de acordo com a afinidade e especialidade de cada autor.

\subsection{LEGISLAÇÕES E CERTIFICAÇÕES}

É sabido que o setor da construção civil é um grande consumidor de energia e recursos naturais, além de um grande gerador de poluição e resíduos. Desta forma, uma sociedade que queira alcançar a sustentabilidade neste setor deve ter políticas específicas neste sentido.

No exterior, a preocupação com a sustentabilidade ambiental na segunda metade do século XX renasce das discussões sobre consumo de recursos naturais. A partir da década de 70 intensificam-se convenções internacionais para discutir metas de desaceleração do consumo de recursos naturais, redução da contaminação do meio ambiente, diminuição da emissão de resíduos, tais como, a Conferência das Nações Unidas sobre o Ambiente Humano (Estocolmo, 1972); a Convenção de Viena para Proteção da Camada de Ozônio (Viena, 1985); o Protocolo de Montreal (Montreal, 1987); a Conferência das Nações Unidas sobre Ambiente e Desenvolvimento - ECO’92 (Rio de Janeiro, 1992), Conferência das Nações Unidas (Istambul, 1996) e o Protocolo de Kyoto (1997). Percebe-se que a Organização das Nações Unidas - ONU levantou esta bandeira de alerta para os desequilíbrios ambientais por meio de grandes eventos internacionais que entraram para a história.

De acordo com Lamberts et al (2008) as conferências marcam uma era de discussões que seriam posteriormente internalizadas pelos países em regulamentos, certificações, incentivos governamentais e iniciativas públicas e privadas com foco na sustentabilidade, principalmente, da década de 90 em diante.

Um exemplo disso, também citado por Lamberts et al. (2008), ocorreu durante o Habitat II, em 1996, Istambul. Na ocasião, profissionais definiram a aplicação do desenvolvimento sustentável para o setor da construção. Tal iniciativa provocou 
repercussão imediata, pondo em evidência riscos para a saúde por parte de certos materiais, como o amianto, e despertando o interesse da opinião pública para a preservação do meio ambiente e criação de um entorno saudável. Desde então, profissionais e indústrias Européias de construção começaram a considerar a dimensão ecológica, surgindo normas, regulamentações e incentivos financeiros em países como Alemanha, França e Suíça (Wines, 2000).

Ainda na década de 90, no exterior, surgem as certificações de edifícios projetados de forma ambientalmente responsável, como um instrumento idôneo que poderia ser tomado como referência para incentivos governamentais e como diferencial no mercado. Vários países no mundo têm ou estão produzindo leis e incentivos para edificações certificadas com relação à sustentabilidade ambiental. Os sistemas de certificação começaram na Europa e essa forma de incentivo difundiu-se em outros países.

Silva et al (2003) levantaram, há mais de uma década, que praticamente cada país europeu, além de Estados Unidos, Canadá, Austrália, Japão e Hong Kong, já possuía um sistema de avaliação de edifícios, sendo que todos eles concentravam-se exclusivamente na dimensão ambiental da sustentabilidade. Esses sistemas foram amplamente estimulados por agências governamentais, instituições de pesquisa e pelo setor privado de diversos países.

Silva et al (2003) destacaram ainda que esses sistemas de avaliação se distinguem em duas categorias. De um lado, aqueles orientados para o mercado, isto é, desenvolvidos com estrutura mais simples para serem facilmente absorvidos por projetistas e para receber e divulgar o reconhecimento do mercado pelos esforços dispensados para melhorar a qualidade ambiental de projetos, execução e gerenciamento operacional. Este é o caso do BREEAM (Building Research Establishment Environmental Assessment Method), LEED (Leadership in Energy and Environmental Design), CSTB (Centre Scientifique et Technique du Bâtiment), dentre outros. De outro lado, estão os esquemas de avaliação orientados para pesquisa, como o BEPAC (Building Environmental Performance Assessment Criteria) e o seu sucessor, o GBC (Green Building Challenge), em que a ênfase é o desenvolvimento de um método abrangente e com fundamentação científica, que possa orientar o desenvolvimento de novos sistemas. 
Nos Estados Unidos, com relação a incentivos, os municípios regulamentaram diferentes formas de estimular edifícios certificados. O AIA - The American Institute of Architects, procedeu uma revisão abrangente de construção verde e de incentivos dos governos locais americanos em 2008. Na época, o AIA reuniu um grupo de arquitetos de renome, desenvolvedores, financiadores imobiliários, varejistas e proprietários de edifícios para identificar incentivos ativos que tiveram grande apelo e comprovados resultados nos setores público e privado.

Um exame desses incentivos, disponibilizado no documento "Local Leaders in Sustainability Green Building Incentive Trends" (AIA e NACo, 2012, p.4) indicou que os incentivos mais atraentes para o setor privado, e logo, os com maior grau de aderência, são:

1. Incentivos Fiscais - Redução de impostos perante a implementação de medidas voltadas à sustentabilidade e/ou certificações específicas;

2. Bônus de Área Bruta / Área Construída - Consiste em um bônus que flexibiliza os padrões pré-determinados de Área Bruta / Área Construída, agregando bônus de altura máxima do edifício, bônus de redução da necessidade área verde, ou a contabilidade de telhado verde como área verde, por exemplo; e

3. Permissões (Alvarás) - Prazos e procedimentos mais céleres de aprovações e emissões de permissões de construção para edifícios certificados e/ou com medidas voltadas à sustentabilidade.

Além das regulamentações específicas, os governos locais também descobriram que uma maneira eficaz de aumentar a vida útil de programas de incentivo é a mobilização de fundos privados para programas de empréstimo. A ideia consiste em disponibilizar juros baixos para projetos verdes.

Segundo o levantamento do AIA e NACo (2012), alguns dos exemplos da regulamentação destes incentivos ocorreram em Cincinnati-OH e Montgomery County $\mathrm{MD}$, com o estabelecimento de reduções de taxas e tributos específicos para construções sustentáveis; em Arlington County-VA e Bloomington-IN, com o estabelecimento de bônus referentes aos padrões de ocupação do solo; e em Chicago-IL e San Diego-CA, com iniciativas referentes aos procedimentos de permissões mais céleres e menos burocráticas para projetos com diferenciais sustentáveis. 
Segundo Dernbach e Tyrrell (2010), as regulamentações municipais e estaduais nos EUA foram provocadas ainda em 1976, com o Ato de Conservação de Energia e Produção, onde foi delegado a cada estado a definição de padrões de eficiência energética para os novos edifícios comerciais e residenciais. Em 1978, o Congresso aprovou a Lei da Política Nacional de Conservação de Energia, que instalou uma auditoria energética do estado visando a economia de energia em edifícios e inaugurou a rotulagem da eficiência energética.

No âmbito Federal, o Estados Unidos estipulou uma dedução fiscal conhecida como "The Energy Efficient Commercial Building Tax Deduction, IRS 179D”, também chamada EPACT. A medida foi projetada buscando recompensar os proprietários de edifícios comerciais que adotam padrões mais elevados de eficiência energética. Segundo a Sustainable Energy Associates (2010), a dedução fiscal considera questões de iluminação e fechamento dos edifícios para estipular as taxas de dedução variáveis, e os projetos sustentáveis podem ser comprovados, tanto por meio de certificações, como por meio de pareceres de profissionais arquitetos ou empresas construtoras que projetam edifícios verdes (DERNBACH E TYRRELL,2010).

Já na Europa o mercado também adotou iniciativas de arquitetura sustentável. Mais recentemente, em 2012, a União Europeia, por meio do Conselho de Ministros e do Parlamento Europeu, considerou uma estratégia mais ousada ao publicar a nova Diretiva de Eficiência Energética. A diretiva traça os elementos do Plano de Eficiência Europeu para os Estados-Membros, incluindo uma taxa anual de reformas de edifícios da administração pública de, no mínimo, 3\%; uma obrigação aos órgãos públicos para aquisição de produtos, serviços e edifícios com alto desempenho de eficiência energética; e obrigações para a indústria, relativas a auditorias energéticas e à gestão da energia, com metas de economia anual de energia de 1,5\%. A meta de eficiência energética da UE é de $20 \%$ até o ano de 2020 (DERNBACH E TYRRELL,2010).

No Brasil, Sobreira (2008) afirmou que já percebia-se uma pressão social e política crescente sobre a arquitetura para a inclusão e consolidação de uma agenda ambiental na prática profissional e na formação acadêmica no período entre 2000 e 2007. Em análise de concursos públicos de arquitetura realizada pelo autor, verificou-se que a questão ambiental foi incorporada e incluída no discurso sobre a intenção projetual, no entanto, a maioria dos concursos não tratou diretamente da questão ambiental em seus critérios de 
análise e, quando o tema foi abordado, observou-se superficialidade e diversidade terminológica.

Desta forma, observou-se que a introdução no mercado brasileiro de sistemas de avaliação e certificação de edificações sustentáveis aconteceu de forma mais tardia, aproximadamente uma década depois dos cenários internacionais como Estados Unidos e Europa. Destaca-se que os primeiros sistemas de avaliação introduzidos no Brasil e mais conhecidos foram, em sua maioria, derivados de sistemas de avaliação pré-existentes em outros países, inclusive já citados. São eles: BREEAM, LEED, GBC e AQUA (Sistema de Alta Qualidade Ambiental). De acordo com Pereira (2010, pg. 72) o AQUA, lançado em 2009, foi baseado no HQE (Haute Qualité Environnementale - França). Explica-se que estes sistemas, em maior ou menor escala, sofreram algumas adaptações voltadas às características bioclimáticas brasileiras, contudo, alguns de forma muito superficial.

Com relação a ações governamentais no Brasil, o marco para a sustentabilidade ambiental no quesito da energia foi a publicação da Lei $N^{\circ} 10.295$ (2001- Lei de Eficiência Energética) que dispõe sobre a Política Nacional de Conservação e Uso Racional de Energia. Reforça-se que nos Estados Unidos lei similar foi publicada em 1978.

A partir da publicação da Lei de Eficiência Energética, em 2001, o PBE (Programa Brasileiro de Etiquetagem) passou a estabelecer programas de avaliação de produtos do mercado de forma compulsória, o que antes acontecia de forma voluntária (INMETRO, 2014). Com a evolução do programa, em 2009, são publicados os primeiros regulamentos técnicos voltados a etiquetagem de edificações por meio do programa PBE-Edifica, porém de forma voluntária.

Já na presente década, também seguindo uma tendência internacional porém de forma mais tardia, foram adotadas políticas públicas mais específicas para a promoção da sustentabilidade ambiental na construção civil, além de regulamentos mais específicos. Dentre as publicações mais recentes podemos destacar três que incidem mais diretamente no recorte da sustentabilidade delimitado para esta dissertação de mestrado, são elas: a Instrução Normativa $n^{\circ}$ 01/2010 (MPOG); a Instrução Normativa nº 02/2014 (MPOG) e a NBR 15575:2013 (ABNT).

O Governo Federal, por meio da $\mathrm{IN} \mathrm{n}^{\circ} 01$ do Ministério do Planejamento, Orçamento e Gestão- MPOG (2010) determinou que as obras públicas devem adotar critérios 
sustentabilidade ambiental em diversas das suas etapas. Este documento normatiza uma série de ações na gestão e aquisição de bens e serviços para obras públicas federais. A IN $n^{\circ}$ 01/2010 determina que as obras e serviços de engenharia, devem ser elaborados visando a economia na manutenção e operacionalização da edificação, redução do consumo de energia e água e utilização de tecnologias e materiais que reduzam o impacto ambiental.

Destaca-se, entretanto, que o Governo Federal ainda não dispõe nenhum método avaliativo para verificar o atendimento dessas premissas, mas a $\mathrm{IN} \mathrm{n}^{\circ}$ 01/2010 serve como subsídio para ações voltadas à sustentabilidade serem implementadas no setor público.

Com a publicação da IN n ${ }^{\circ}$ 02/2014 (MPOG) o Governo Federal ratificou o programa PBE -Edifica a etiquetagem compulsória de edificações definidas no documento RTQ-C (Requisitos Técnicos da Qualidade para o Nível de Eficiência Energética de Edifícios Comerciais, de Serviços e Públicos (BRASIL, 2010 b)). Em breve, aguarda-se a etiquetagem de forma compulsória também de edificações residenciais por meio do documento vigente RTQ-R (Regulamento Técnico da Qualidade para o Nível de Eficiência Energética de Edificações Residenciais (BRASIL, 2010 c)).

Considerando o consumo de energia elétrica no Brasil, o PROCEL (2012) estima que 45\% do que se produz no país seja consumido na operação e manutenção de edificações e na promoção de conforto aos seus usuários. Sendo que o potencial de conservação de energia em edificações é expressivo, sendo avaliado em 30\% para edificações já existentes, através de reformas, e podendo chegar a $50 \%$ nas edificações novas que preveem a eficiência energética desde a concepção inicial do projeto.

De acordo com o RTQ-C (BRASIL, 2010 b) a concessão da etiqueta de classificação energética para as edificações é realizada nas seguintes fases: projeto de nova edificação; edificação concluída (após o Habite-se); e edificação existente (após a reforma com vistas à melhoria da eficiência energética). A etiqueta está dividida em três partes: envoltória, sistema de iluminação, sistema de condicionamento de ar e a obrigatoriedade aplica-se a edifícios com área total útil mínima de 500 m².

Desta forma, as instruções normativas, normas técnicas e o PBE- Edifica juntamente com os sistemas de avaliação e certificação de edificações existentes no Brasil surgem como resposta à necessidade da concepção de edificações mais sustentáveis, com destaque para a eficiência energética das mesmas. Observa-se que os indicadores de sustentabilidade 
de edificações do mundo todo têm sempre entre seus principais critérios de avaliação o quesito da eficiência energética.

A Associação Brasileira de Normas Técnicas - ABNT publicou em 2013 a NBR 15575 para Edificações Habitacionais -Desempenho (ABNT, 2013). O texto institui nível de desempenho mínimo ao longo de uma vida útil para os elementos principais (como estrutura, vedações, instalações elétricas e hidrossanitárias, pisos, fachada e cobertura) de toda e qualquer edificação habitacional. Desta forma, os fabricantes passam a se mobilizar para adequar seus produtos e processos de fabricação às exigências da norma. Esta NBR 15575:2013 veio estimular a indústria da construção a produzir materiais e edificações com maior qualidade e durabilidade, aspectos muito relevantes quando se trata de sustentabilidade.

Estas ações, apesar de estarem acontecendo de forma mais tardia com relação a países mais desenvolvidos são um reforço na promoção da mudança do cenário da construção civil nacional, por meio de legislação, regulamentação, capacitação e certificações estimula-se a alteração do padrão de atuação dos arquitetos voltando-o mais para ações no âmbito da sustentabilidade. Verifica-se já há algum tempo que as ações citadas vêm gerando reflexos tanto na graduação quanto na pós-graduação, incluindo a atualização de profissionais já em pleno exercício. 


\section{O ENSINO DA SUSTENTABILIDADE NA ARQUITETURA}

\section{E URBANISMO}

O presente capítulo apresenta um breve histórico do surgimento das escolas de Arquitetura e Urbanismo, posteriormente, apresenta-se características do ensino da sustentabilidade no exterior; e, embasados na legislação profissional e documentos institucionais, características do ensino no Brasil, identificando conhecimentos e atribuições delegados ao arquiteto e urbanista ao longo dos últimos anos. Além disso, é tratado o aspecto da integração dos conteúdos nos currículos, de forma a colaborar para o entendimento do panorama atual deste ensino.

\subsection{PERSPECTIVA HISTÓRICA}

A formação do arquiteto, em relação à educação escolarizada, existe há três séculos. Segundo Villela (2007), a criação da Academie Royale d’Architecture em 1671 na França, iniciou a institucionalização do ensino de arquitetura, pois até então o conhecimento técnico era passado de mestre a aprendiz.

No Brasil, estabeleceram-se dois caminhos para o ensino da arquitetura, a escola Politécnica e a de Belas Artes:

- Escolas Politécnicas: a Real Academia de Artilharia, Fortificação e Desenho, criada em 1792, passou a chamar-se Escola Politécnica do Rio de Janeiro, em 1874. Já em 1894 é fundada a Escola Politécnica de São Paulo, que passou a formar engenheiros-arquitetos (FLORENÇANO E ABUD, 2002). Ambas escolas inspiradas na École Polytechnique de Paris.

- Escola Nacional de Belas Artes: Em 1800, foi criada a aula prática de desenho e figura na cidade de São Paulo. O sistema de ensino teve também origem francesa, na Academie Royale d'Architecture. A instalação da Academia Imperial das Belas Artes se deu em definitivo em 1826, quando finalmente começou a ser ensinada a arquitetura, mas não como curso exclusivo para esta área, mas somente enquanto belas artes. Em 1890 esta Academia passou a chamar-se na Escola Nacional de Belas Artes, ENBA, um símbolo do ensino de arquitetura de caráter Beaux Arts, o modelo institucional até a década de 1930. 
Segundo Villela (2007), o ensino de arquitetura era constituído dos dois modelos distintos: "Polytechnique", adotado pela escola Politécnica, que formava engenheirosarquitetos, e apresentava caráter tecnicista; e o modelo "Beaux Arts", que apresentava caráter artístico e humanista, formando e designando arquitetos, um curso com caráter artístico em detrimento ao caráter técnico, sem muita integração entre ambos.

Somente em 1930 foi criada a primeira escola de arquitetura no país autônoma em relação às escolas de Belas Artes e de Engenharia (Politécnica): a Escola de Arquitetura de Belo Horizonte, cujo ensino apresentava disciplinas técnicas da engenharia, e artísticas das Belas Artes. Embora essa escola fosse independente dos dois modelos, e apresentasse disciplinas de ambos, a integração das disciplinas técnicas com as artísticas continuava sendo complicada, de acordo com relatos dos estudantes. Posteriormente, em 1949, a Escola foi incorporada à Universidade Federal de Minas Gerais, UFMG.

De acordo com Florençano e Abud (2002) surgiram, também de forma independente das escolas politécnicas e de Belas Artes, logo após a escola mineira: a Faculdade Nacional de Arquitetura - FNA, (1946- Rio de Janeiro), separada da Escola Nacional de Belas Artes; a Faculdade de Arquitetura Mackenzie (1947- São Paulo), desmembrada da Escola de Engenharia Mackenzie; e a Faculdade de Arquitetura e Urbanismo da Universidade de São Paulo (1948), desmembrada da Escola Politécnica.

Em 1960 foi inaugurada a nova capital federal, Brasília. Esse acontecimento deu ao movimento moderno na arquitetura um destaque que seria fundamental na constituição do novo ensino de Arquitetura e Urbanismo, principalmente na própria capital. Em 1962 foi criada a Universidade de Brasília - UnB, a primeira universidade do país que não aconteceu a partir da agregação de faculdades já existentes, isso permitiu que fossem feitas experiências na sua estrutura organizacional e didática pelos seus fundadores, Anísio Teixeira e Darcy Ribeiro (VILLELA, 2007). A UnB surgiu como um novo modelo universitário focado na integração entre ensino, pesquisa e extensão.

A Faculdade de Arquitetura e Urbanismo da UnB- FAU/UnB, por sua vez, é uma unidade acadêmica que tem como finalidade o desenvolvimento, a transmissão e a difusão da cultura, da ciência e da tecnologia, colocando-as a serviço da sociedade. Ou seja, a FAU/UnB nasceu com forte caráter de responsabilidade social, provindo de seu perfil de universidade pública e gratuita. Este curso também possui como forte característica a 
flexibilidade curricular. Na seção 5.2.4 apresentam-se características mais específicas do ensino na FAU/UnB, já que este foi um dos cursos analisados nesta dissertação de mestrado.

\subsection{PERSPECTIVA INTERNACIONAL}

Em todo o mundo, frente ao grande destaque que vem sendo à temática da sustentabilidade nos últimos anos, são visíveis os esforços das instituições de ensino em preparar a sociedade para ser mais sustentável, seja nos procedimentos cotidianos da vida urbana, seja no desempenho profissional.

De acordo com McKeown (2002) em vários países, assim como no Brasil, os conhecimentos sobre o uso responsável de recursos naturais eram, até a década de 90, incipientes no ensino fundamental e oferecidos de forma muito técnica e teórica no ensino superior, o que dificultava colocar em prática ações no cotidiano ou no desempenho da profissão.

Atualmente, evidencia-se que existem significativas ações para incorporar responsabilidade ambiental desde a educação infantil, tanto no Brasil quanto no exterior. Dentre essas, destaca-se o Education for Sustainable Development Toolkit, publicado nos Estados Unidos, que apresenta um conjunto de orientações, material didático e métodos de ensino que visam alterar o currículo padrão das escolas, do ensino fundamental ao médio, incorporando no aprendizado, além do conhecimento sobre sustentabilidade, a constante ação e pensamento crítico à cerca do tema, de forma abrangente em todas disciplinas. (McKeown, 2002).

Ações deste tipo visam moldar o comportamento humano, para que ao entrar no ensino superior, o cidadão já consiga refletir sobre as ações profissionais a favor da sustentabilidade, seja qual for a sua área de qualificação.

Em pesquisa realizada com docentes do Curso de Arquitetura e Urbanismo da Escola de Engenharia de São Carlos- EESC, Pasevi e Freitas (2008, p.116) identificaram, a grosso modo, três formas de abordagem para prática de projeto voltada à sustentabilidade no currículo dos curso de arquitetura: 
1. A primeira se baseia no pressuposto de que a sustentabilidade permeia o currículo da arquitetura desde suas origens. Logo, a sustentabilidade seria inerente à teoria e prática da arquitetura, não havendo necessidade de qualificála como uma preocupação "nova" e enquadrá-la em um programa de formação profissional.

2. A segunda abordagem considera a existência de matérias e pesquisas sobre "sistemas de controle e gestão ambiental", que proveriam os conhecimentos técnicos necessários para definição de critérios para bom desempenho ambiental. Essa abordagem pressupõe o acréscimo de conteúdos nas matérias/disciplinas da área de tecnologia e também prevê a integração desses conhecimentos ao projeto, para que os conhecimentos possam avançar para além da dimensão técnica da sustentabilidade ${ }^{1}$.

3. A terceira abordagem prevê que a sustentabilidade seja incorporada em suas múltiplas dimensões pela Instituição de Ensino Superior- IES e conste como pauta de um programa de revisão global tanto do currículo como do projeto político pedagógico. Propõe-se uma reflexão mais ampla e uma discussão conceitual necessárias para superar uma interpretação da noção de sustentabilidade marcada pela rigidez, e para subverter um procedimento bastante comum de verificação do grau de sustentabilidade de um objeto arquitetônico ou material, que, de maneira geral, focam um número muito limitado quando não um único indicador de sustentabilidade (PASEVI E FREITAS, 2008).

Independente da abordagem escolhida, Pasevi e Freitas (2008) identificaram uma tendência nas escolas de Arquitetura e Urbanismo, de que a educação para a sustentabilidade aconteça de forma mais prática e presente durante todo o curso, e não em disciplinas teóricas isoladas em períodos específicos do currículo.

Destaca-se no cenário Internacional um grupo de publicações provindas da Organização das Nações Unidas - ONU. Sua importância é tal que se fizermos um paralelo do crescimento da temática da sustentabilidade com as publicações sobre o tema da ONU,

\footnotetext{
${ }^{1}$ Destaca-se que esta é a forma de abordagem explorada pelo grupo EDUCATE - referência metodológica para as análises que foram realizadas nesta dissertação.
} 
observaremos que a temática da sustentabilidade tem crescido de forma muito próxima às rientações produzidas por esta organização. As publicações vêm acompanhando os caminhos galgados no desenvolvimento da temática em diversas áreas.

Primeiramente, podemos ressaltar a publicação da Agenda 21 (UNCED, 1992), documento que colocou a temática da sustentabilidade em destaque mundial; posteriormente, a Agenda 21 for Sustainable Construction in Developing Countries (CIB/UNEP, 2002), que destacou os grandes impactos gerados pela Indústria da Construção e suas consequências ambientais; na sequência, é declarado pela Assembleia das Nações Unidas a Década das Nações Unidas da Educação para o Desenvolvimento Sustentável- DEDS (2005 a 2014); e por fim, o Guidelines on Education Policy for Sustainable Built Environments (UNEP, 2010), um guia que veio chamar a atenção para a importância do ensino da temática na área de Arquitetura e Urbanismo.

O Guidelines on Education Policy for Sustainable Built Environments (UNEP, 2010), visando a evolução do ensino no sentido da sustentabilidade, apresenta recomendações estratégicas, objetivos políticos e educacionais a serem considerados em diversos segmentos da sociedade. Dentre os quais:

1- profissionais da Arquitetura e Urbanismo;

2- associações profissionais dos arquitetos, urbanistas, paisagistas, gestores da construção, etc;

3- Instituições de Ensino Superior- IES.

Primeiramente, a recomendação do guia citado seria para que as associações profissionais de cada país tentassem garantir que a temática da sustentabilidade fosse incorporada aos conhecimentos dos profissionais atuantes no mercado e a estratégia de implementação seria a verificação do conhecimento teórico e prático do tema como condição para a emissão da licença para atuação profissional. Esta verificação poderia se dar por meio de procedimento de avaliação para comprovação dos conhecimentos adquiridos na formação, tal como ocorre no licenciamento profissional da Ordem dos Advogados do Brasil (prova da OAB).

Mazria (2003, p.51) também aponta tal caminho para o Nacional Architectural Accrediting, conselho de licenciamento profissional dos Estados Unidos, indicando que este deve fazer a verificação das escolas de arquitetura que considerem a sustentabilidade 
como base de seus currículos e que possuam cursos específicos direcionados ao estudo dos impactos ambientais. Indica também que os conselhos de licenciamento estaduais devem incluir em seus exames profissionais um segmento que requeira uma compreensão plena desses princípios.

Em outros países, alguns conselhos de classe trabalham também com a certificação específica para "arquitetos sustentáveis", como um selo que diferencia o profissional dos demais, tal como o "Instituto Real de Arquitetos da Escócia", onde os arquitetos devem apresentar evidências que suas obras construídas possuem características de projeto sustentável (LIDDLE e HALLIDAY, 2005). Tal iniciativa atualmente é voluntária para os profissionais que querem se qualificar como "sustentáveis", porém o órgão já considera, para o futuro, que este seja um requisito obrigatório para o licenciamento periódico dos profissionais.

Posteriormente, com relação a estratégias específicas para as IES, o Guidelines on Education Policy for Sustainable Built Environments (UNEP, 2010) aponta:

- Revisão dos currículos das escolas, buscando envolver os alunos na avaliação e planejamento das ações votadas à sustentabilidade;

- Transformação dos campi em exemplos de arquitetura sustentável, para que os alunos vivenciem cotidianamente a teoria aprendida, além de poder aplicar seus trabalhos técnicos em um ambiente que é um laboratório;

- Reforço do envolvimento com a comunidade através do ensino e pesquisa, buscando estudos de caso e aplicações reais fora da universidade, colaborando para a responsabilidade social e ambiental dos arquitetos.

E, para a revisão dos currículos das escolas, o guia (UNEP, 2010) destaca alguns caminhos:

- Classificar, rever e auditar currículos existentes e programas de ensino e treinamento/capacitação, para identificar lacunas e oportunidades de aprendizagem (entre os currículos), em seguida, desenvolver novos programas para a educação da arquitetura sustentável. 
- Desenvolver e promover métodos de ensino para refletir o caráter holístico da educação para sustentabilidade e destacar os fatores interdependentes da arquitetura com o meio ambiente.

- Incentivar a produção, publicação e divulgação de projetos, trabalhos acadêmicos e ações sustentáveis em revistas científicas e meios de comunicação.

- Garantir reforço progressivo dos princípios e valores da sustentabilidade, conhecimentos e habilidades através de cada período do programa de estudo.

Destaca-se que o primeiro caminho elencado para a revisão dos currículos está em consonância com a análise desenvolvida na presente dissertação de mestrado, conforme já descrito na justificativa deste trabalho. Os demais caminhos são vistos como ações bastante relevantes para fortalecer o ensino da temática em qualquer escola.

Por fim, o Guidelines on Education Policy for Sustainable Built Environments orienta:

"As escolas de arquitetura devem adotar a sustentabilidade como uma convicção do núcleo e, portanto, uma das principais razões para a educação oferecida. O ensino de projeto sustentável deve ser totalmente integrado no currículo. Isso requer o desenvolvimento de uma visão que estabelece uma filosofia de direção para toda a educação.(...).

(UNEP, 2010, p.52)

De acordo com o guia (UNEP, 2010), esta última orientação só seria possível se contasse com o engajamento de todo o pessoal docente e, para isso, seria necessária prévia qualificação e capacitação de todos os professores do curso.

Além do guia publicado pela ONU, outros dois importantes projetos vêm impactando os currículos e métodos de ensino de diversas universidades: o Sustainable Environmental Design Education -SEDE, voltado para o ensino nos Estados Unidos e o Environmental Design in University Curricula and Architectural Training in Europe- EDUCATE, que trata o ensino em diversos países, principalmente em universidades europeias.

Nos Estados Unidos até, recentemente, a situação do ensino não se apresentava muito diferente da brasileira em alguns aspectos. Em diagnóstico feito por Mazria (2003, p. 50), existiam 124 escolas de arquitetura registradas nos EUA, somando mais de 30.000 alunos 
matriculados, no entanto, menos da metade dessas escolas teriam professores com compreensão suficiente para orientar projetos sustentáveis. E, nas escolas com professores qualificados na temática, muitas teriam apenas um membro do corpo docente com a experiência necessária para o ensino.

Apesar dos problemas citados, destaca-se que nos Estados Unidos, conforme aponta Rowe (2007), as escolas de arquitetura, ainda assim, estão na vanguarda nacional de uma educação aborda a sustentabilidade, com relação a outros cursos superiores correlacionados a impactos ambientais significativos. O SEDE (2012) tem o objetivo de alinhar os procedimentos pedagógicos sobre o ensino de sustentabilidade nas escolas de Arquitetura e Urbanismo.

Partindo do princípio que a sustentabilidade para o SEDE (2012) consiste nos princípios e práticas de arquitetura e paisagem que protegem a qualidade ambiental e a saúde humana, visando reduzir os impactos ambientais resultantes de alterações físicas aos edifícios e paisagens, e melhorar o ciclo de vida dos investimentos naturais, humanos e financeiros nos ambientes construídos e naturais, o SEDE trabalhou de forma teórica a sustentabilidade no ensino da arquitetura e consolidou suas propostas em um currículo ideal que tem como núcleo o ensino do tema. Pode-se observar que é mantido de forma paralela ao longo do curso a prática de projeto sustentável e o conhecimento histórico da arquitetura. A Figura 3 apresenta a estrutura curricular proposta. 


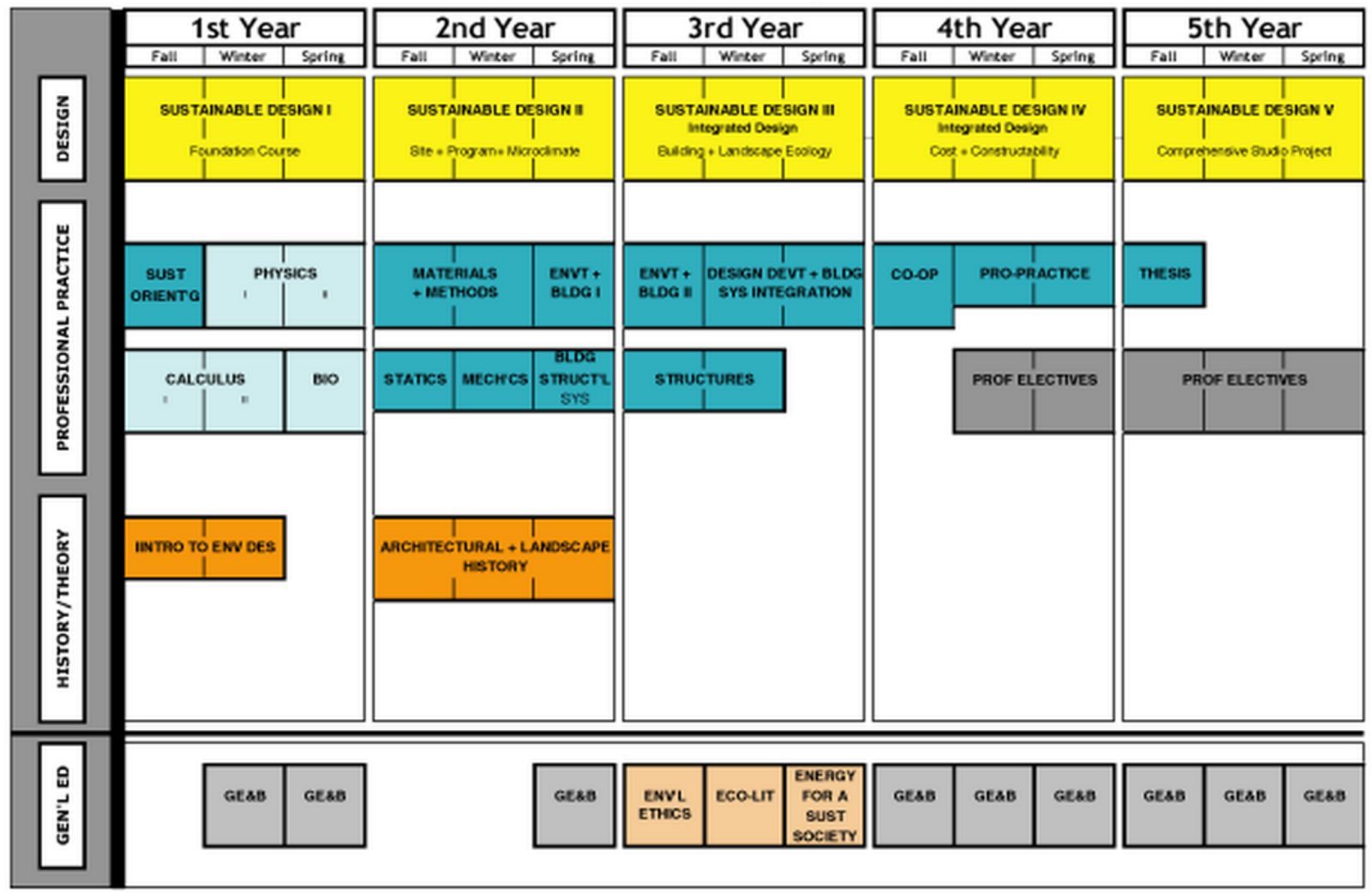

Figura 3: Um bacharelado idealizado em Arquitetura Ecológica (Fonte: SEDE, 2012,

$$
\text { p.01). }
$$

Com relação ao currículo proposto, pode-se observar que a maioria das disciplinas está relacionada à temática da sustentabilidade. São elas:

\section{Projeto Sustentável I: Curso fundamental;}

2.Orientação para a Sustentabilidade: Curso Preparatório;

3. Introdução às questões do Ambiente Construído;

4. Projeto Sustentável II: Sítio e projeto bioclimático;

5. Projeto Sustentável III: Projeto Integrado - Construção, paisagem e ecologia;

6. Projeto Sustentável IV: Projeto Integrado - Construção e Economia;

7. Projeto Sustentável V: Estúdio de Projeto Integral;

8. Experiência de Educação cooperativa;

9. Materiais e métodos de construção;

10. Desenvolvimento de projetos Integrados aos Sistemas de Construção;

11. Sistemas Ambientais;

12. Sistemas Estruturais;

13. História da Arquitetura e Urbanismo no projeto sustentável de Ambientes Construídos; 


\section{Disciplinas Optativas/Eletivas profissionalizantes;}

\section{Educação Geral à distância."}

Já na Europa, o Acordo de Bolonha assinado em 1999 contou com a adesão de quase todos os países europeus e tinha como objetivo principal a ideia da centralidade da Europa no fornecimento de serviços educativos. Desta forma, a declaração marca uma mudança em relação às políticas ligadas ao ensino superior dos países envolvidos e estabeleceu em comum um Espaço Europeu de Ensino Superior a partir do comprometimento dos países signatários em promover reformas dos seus sistemas de ensino (Lima et al, 2008).

Em termos de programa de ensino, quase todos os países europeus seguem estrutura proposta como parte de implementação do acordo de Bolonha. Logo, a maioria dos currículos é formado por três ciclos de qualificação no ensino superior.

- $1^{\text {o }}$ ciclo - três anos - título de bacharelado (intitulado "undergraduate", concentra a transmissão de conhecimentos gerais e aquisição das principais competências necessárias ao processo de projeto);

- $2^{\circ}$ ciclo - um ano e meio a dois anos - título de mestrado (investem na aplicação de know-how, especialização, e pesquisa);

- $\quad 3^{\text {o }}$ ciclo - três a cinco anos - título de doutorado (investem na aplicação de knowhow, especialização, e pesquisa em nível mais aprofundado).

De acordo com o EDUCATE (2012 d), uma abordagem global e verdadeiramente integrada para o ensino do projeto sustentável ainda é adotada de forma fragmentada em escolas de arquitetura europeias. Estes conteúdos são, por vezes, ministrados em matérias eletivas que não estão disponíveis no início do curso, ou como módulos de especialização oferecidos na graduação ou pós-graduação. Em alguns casos, a sustentabilidade é valorizada como um componente obrigatório da formação, mas geralmente, em fases mais adiantadas da graduação. Quando os conhecimentos e os conteúdos são efetivamente transmitidos, raramente estão integrados com a prática de projeto ou com outras disciplinas.

A pouca conscientização aliada à limitada formação de tutores neste domínio disciplinar mostra alguns dos atuais limites para a implementação do projeto sustentável de forma integrada nos cursos de arquitetura do mundo, e explica as razões por que a 
sustentabilidade é, muitas vezes, considerada como uma qualidade "adicional" adquirida por estudantes, ao invés de ser considerada como um ativo fundamental do currículo.

No entanto, de acordo com o EDUCATE (2012 d), as IES da Europa demonstram consciência da necessidade de incorporar a sustentabilidade em suas disposições educacionais, compartilham da noção de multi / inter / transdisciplinaridade e reconhecem a importância da abordagem da temática focada no projeto como elemento central. Logo, a temática em países europeus está em processo intenso de incorporação curricular e impactando como um modelo a ser seguido nos demais cursos de graduação.

Podemos destacar a Universidade de Nottingham, como uma universidade inteiramente dedicada ao tema da arquitetura sustentável, a começar pelos edifícios que proporcionam aos alunos a vivência e o estudo prático da arquitetura sustentável, com seus prédios concebidos com um grande número de inovações em materiais de construção, mecanismos de iluminação natural, acumulação de calor, tratamento acústico, geração de energia nas fachadas usando células fotovoltaicas, coleta e reuso de água, e pesquisa com outros recursos e técnicas, como levantado por Gonçalves e Duarte (2006).

Observe-se que o EDUCATE analisou, com foco na abordagem da sustentabilidade nos currículos, diversas escolas de Arquitetura e Urbanismo da Europa (dentre elas Universidade de Nottingham, citada acima). As análises realizadas pelo grupo foram amplas e servem como um ponto de partida para as análises realizadas nesta dissertação, acrescentando sugestões de boas práticas internacionais ao ensino da sustentabilidade nas escolas brasileiras, salvaguardadas as divergências no sistema de ensino.

Por fim, observa-se que a investigação quanto a melhor forma de ensinar a sustentabilidade nos cursos de Arquitetura e Urbanismo não se limita ao cenário acadêmico nacional, sendo também uma preocupação de cunho acadêmico internacional. Observa-se também que a sustentabilidade se apresentou como um tema de grande relevância no cenário internacional e suficientemente motivador para iniciar mudanças nas formas de ensino insatisfatórias. 


\subsection{PERSPECTIVA NO BRASIL}

Em crítica sobre o ensino da arquitetura, Lara (2008, p.01) afirma que "perguntar quais os conteúdos fundamentais para a formação do arquiteto hoje já seria uma forma de construir pontes entre o ensino e a prática de arquitetura”. Desta forma, tentamos a seguir identificar qual o papel do arquiteto na sociedade, por meio da análise da legislação e do entendimento de alguns autores, dando enfoque na abordagem da temática da sustentabilidade.

Deve-se ficar claro, primeiramente, que o papel do arquiteto não se restringe apenas ao desenvolvimento de projetos e que existem várias vertentes para a atuação deste profissional no mercado. No Brasil, a Lei Nº 12.378 (2010), regulamenta o exercício da profissão e lista as atribuições do arquiteto e urbanista:

"I- supervisão, coordenação, gestão e orientação técnica;

II- coleta de dados, estudo, planejamento, projeto e especificação;

III- estudo de viabilidade técnica e ambiental; (...)

VIII- treinamento, ensino, pesquisa e extensão universitária;

IX- desenvolvimento, análise, experimentação, ensaio, padronização, mensuração, controle de qualidade; (...)”

$\left(\right.$ LEI N $.12378,2010$, Art. $\left.^{\circ}\right)$

O exercício profissional do arquiteto e urbanista no Brasil é de habilitação única, ou seja, não há modalidades na profissão. Toda a legislação de regulamentação profissional (responsabilidade técnica e social) tem caráter nacional, podendo os arquitetos e urbanistas exercerem sua profissão em qualquer parte território nacional.

Destaca-se, ainda, no artigo $3^{\circ}$ da LEI $N^{\circ} .12 .378$ (2010), que os campos da atuação profissional para o exercício da Arquitetura e Urbanismo são definidos a partir das diretrizes curriculares nacionais que dispõem sobre a formação do profissional arquiteto e urbanista e caracterizam a unidade de atuação profissional.

Segundo as diretrizes curriculares vigentes (MEC,2010), o objetivo básico da educação superior em Arquitetura e Urbanismo no Brasil é: 
“(...) assegurar a formação de profissionais generalistas, capazes de compreender e traduzir as necessidades de indivíduos, grupos sociais e comunidade, com relação à concepção, à organização e à construção do espaço interior e exterior, abrangendo o urbanismo, a edificação, o paisagismo, bem como a conservação e a valorização do patrimônio construído, a proteção do equilíbrio do ambiente natural e a utilização racional dos recursos disponíveis".

(MEC, 2010)

As diretrizes curriculares apontam que o conteúdo curricular no ensino de Arquitetura e Urbanismo no Brasil deve manter o equilíbrio entre os aspectos teóricos e práticos, e definem também que o mesmo deve compreender, obrigatoriamente, três partes:

“- O Núcleo de Conhecimentos de Fundamentação: Estética e História das Artes; Estudos Sociais e Econômicos; Estudos Ambientais; Desenho e Meios de Representação e Expressão.

- O Núcleo de Conhecimentos Profissionais: Teoria e História da Arquitetura, do Urbanismo e do Paisagismo; Projeto de Arquitetura, de Urbanismo e de Paisagismo; Planejamento Urbano e Regional; Tecnologia da Construção; Sistemas Estruturais; Conforto Ambiental; Técnicas Retrospectivas; Informática Aplicada; Topografia.

- O Trabalho de Curso."

(MEC, 2010)

Para Kowaltovski (2006) a plena atuação do arquiteto situa-se na transversalidade de vários campos, tais como: qualidade do ambiente construído, conforto ambiental, psicologia ambiental, processo de projeto, informática aplicada e avaliações de projetos e obras em pós-ocupação.

Beatrice (2006), por sua vez, destaca sobre o papel do arquiteto, que é necessária a extensão do conceito de arquitetura bio-climática para o de arquitetura sustentável. Quanto a esse aspecto, seria complementar uma contrapartida social na cobrança de resultados pelo estabelecimento de legislação específica.

"Em sociedades cujo processo de sistematização de recursos naturais está mais aperfeiçoado é responsabilidade do arquiteto, quando da elaboração do projeto, demonstrar todos os impactos que a obra vai causar ao meio ambiente, na construção, no período de 
uso e até em sua desmobilização, este é o caminho natural de desenvolvimento da boa arquitetura e seu correto comprometimento com a sociedade".

(BEATRICE, 2006)

Analisando o enfoque dado à temática da sustentabilidade, ainda nas diretrizes curriculares, observa-se que a mesma foi abordada de forma intrínseca nos quatro princípios relativos ao desenvolvimento de condutas e atitudes com responsabilidade técnica e social:

"I - a qualidade de vida dos habitantes dos assentamentos humanos e a qualidade material do ambiente construído e sua durabilidade;

II - o uso da tecnologia em respeito às necessidades sociais, culturais, estéticas e econômicas das comunidades;

III - o equilíbrio ecológico e o desenvolvimento sustentável do ambiente natural e construído;

IV - a valorização e a preservação da arquitetura, do urbanismo e da paisagem como patrimônio e responsabilidade coletiva".

(MEC, 2010)

Também verifica-se dentre os quatro quesitos relativos ao perfil do profissional em formação, a "proteção do equilíbrio do ambiente natural e utilização racional dos recursos" (MEC, 2010).

Já dentre as competências e habilidades mínimas do profissional, destacam-se, dos treze itens abordados, os seguintes:

"II-a compreensão das questões que informam as ações de preservação da paisagem e de avaliação dos impactos no meio ambiente, com vistas ao equilíbrio ecológico e ao desenvolvimento sustentável;

III- as habilidades necessárias pra conceber projetos de arquitetura, urbanismo e paisagismo e para realizar construções, considerando fatores de custo, de durabilidade, de manutenção e de especificações, bem como os regulamentos legais, de modo a satisfazer as exigências culturais, econômicas, estéticas, técnicas, ambientais e de acessibilidade dos usuários;"

(MEC, 2010) 
Apesar das diretrizes curriculares não tratarem das práticas pedagógicas específicas para o ensino da temática da sustentabilidade, ela orienta que os projetos político pedagógicos dos cursos devem demonstrar claramente como o conjunto das atividades previstas no projeto garantirão o desenvolvimento das competências e habilidades esperadas (MEC, 2010).

O projeto político pedagógico de uma instituição/departamento é a reflexão e a expressão contínua das ideias sobre a educação superior, sobre a universidade e sua função social, sobre o curso, sobre o ensino, sobre a pesquisa e sua relação com o ensino, sobre a extensão e sua relação com o currículo e sobre a relação teoria e prática. Ele é a forma de se explicitar os objetivos de um curso e orientar as estratégias a serem utilizadas (Stocco, 2005).

Logo, as menções relacionadas à sustentabilidade nos documentos apresentados vem reforçar a importância da temática na atualidade e como a mesma é essencial e está diretamente relacionada à formação do profissional arquiteto e urbanista, tornando cada dia mais evidente sua importância.

A partir dos documentos existentes, fica claro que o ensino da graduação fica responsável por incutir os conhecimentos e habilidades devidas ao perfil do arquiteto e urbanista, independente da prática de ensino adotada, de forma a capacitá-lo para o desempenho profissional, seja na concepção de projetos arquitetônicos e urbanísticos ou na atuação com outras atribuições.

De acordo com Xavier (2011), apesar da produção científica brasileira sobre a sustentabilidade aplicada ao ambiente construído ser crescente e relevante, pouco abordava questões atinentes ao ensino até 2011 e focava-se mais aos âmbitos teóricos e práticos. A autora identificou uma lacuna no estado da arte no que tangia à abordagem da sustentabilidade em métodos de ensino e destacava que aos poucos esta vinha sendo preenchida com alguns raros trabalhos, que discutiam pioneiramente essa problemática.

Dourado e Amorim (2013, p.101) identificaram em análise do ensino que a temática da sustentabilidade nos cursos de arquitetura no Brasil acontece de forma diferenciada em cada currículo e com aprofundamento em diferentes enfoques. Ou seja, observou-se que em alguns cursos a abordagem se dá principalmente por meio de disciplinas específicas e, 
em outros, está inserida dentro de disciplinas de outras áreas, juntamente com outras temáticas.

Logo, o que pôde ser constatado é que o ensino da sustentabilidade nas escolas de Arquitetura e Urbanismo no Brasil ainda não possui um perfil definido, porém está ganhando espaço e é permeado por uma heterogeneidade de práticas pedagógicas com aprofundamentos em diferentes enfoques e proporções que se baseiam, sobretudo, no perfil dos professores e da escola cursada.

\subsection{A INTEGRAÇÃO ENTRE TEORIA E PRÁTICA}

Analisando ainda o perfil do ensino da sustentabilidade nas escolas de Arquitetura e Urbanismo no Brasil, observa-se como uma das principais características deste ensino que as disciplinas da cadeia de Conforto Ambiental assumiram, por muito tempo, a quase totalidade dos conteúdos relacionados à sustentabilidade, sendo que as demais disciplinas se mantinham, geralmente, indiferentes à temática.

O ensino de Conforto Ambiental tem status de "matéria profissional" desde a portaria n 1.770 (MEC, 1994). Nele está compreendido o estudo das condições térmicas, acústicas, lumínicas, energéticas e os fenômenos físicos a elas associados, como condicionantes da forma e da organização do espaço. Logo, verifica-se por meio dos temas abrangidos, a estreita relação com a temática da sustentabilidade.

Em análise sobre o ensino do Conforto Ambiental realizada por Vianna (2001), há mais de uma década, já identificava-se como uma das maiores deficiências encontradas no ensino, a falta de integração dos conteúdos teóricos com as disciplinas práticas, disciplinas de projeto. Da mesma forma, tem-se discutido a necessidade de abordagem da sustentabilidade nas disciplinas de projeto, com o intuito de maior apreensão do conteúdo e direcionando ao desenvolvimento de projetos mais sustentáveis.

Para Gonçalves e Duarte (2006), com base em toda a complexidade que compõe um projeto arquitetônico, também não há um modelo único para a produção de uma arquitetura sustentável. E, por mais que sejam estabelecidos requisitos e critérios, não existe um método universal para a elaboração do projeto. 
Verifica-se, atualmente, que na maioria das escolas de Arquitetura e Urbanismo os conteúdos teóricos da sustentabilidade vêm sendo ensinados de modo dissociado das disciplinas de projeto. Logo, considera-se um ensino diferenciado os casos em que ocorre algum método de integração.

"No caso do projeto arquitetônico, é imprescindível que o ensino incorpore as demandas cada vez maiores do ponto de vista da sustentabilidade, incluindo aspectos de conforto e qualidade ambiental. Para isto, a integração das disciplinas e o uso dos instrumentos e ferramentas disponíveis devem ser cuidadosamente preparados e constantemente ajustados aos novos objetivos $e$ requerimentos colocados".

(AMORIM et al., 2008, p.10)

As diretrizes curriculares do curso de Arquitetura e Urbanismo de 2006 (MEC, 2006) já enfatizavam, no art. $3^{\circ}$, a importância da interação, integração e da interpenetrabilidade entre as disciplinas curriculares e entre a teoria e a prática.

Sobre a integração entre teoria e prática no ensino da sustentabilidade nos cursos de Arquitetura e Urbanismo, verifica-se que a maioria dos autores afirma que ações voltadas à sustentabilidade devem ser pensadas, simultaneamente, à concepção de projeto, e não posteriormente como um acessório, pois, nesse caso, os resultados seriam minimizados. Defende-se, ainda, que se a temática da sustentabilidade for incorporada desde cedo ao processo de projeto esta será transmitida de forma espontânea à prática profissional.

Os autores Degani e Cardoso (2002) relatam que a partir da identificação de aspectos e impactos ambientais das atividades desenvolvidas ao longo do ciclo de vida dos edifícios, quando um projeto é analisado sob uma perspectiva de produto global, torna-se possível verificar oportunidades de influências positivas em termos arquitetônicos. As definições dessa primeira fase acarretarão nas consequências das fases seguintes.

Logo, para fins de uma obra de arquitetura ou urbanismo sustentável, são muito importantes as etapas de projeto para o resultado final. O projeto direciona desde as definições preliminares, a execução, o uso, a manutenção, até mesmo o reaproveitamento ou descarte da obra.

Como exemplo, Ceotto (2008) aponta que o maior gasto para operação de um edifício é proveniente do consumo de energias (eletricidades, gás, diesel) e de água potável. É importante destacar o dado de que $80 \%$ do custo e impacto na utilização de energia e água 
de uma edificação são provenientes do uso e operação, ou seja, após a entrega do produto para o usuário, conforme ilustrado na Figura 4 a seguir.

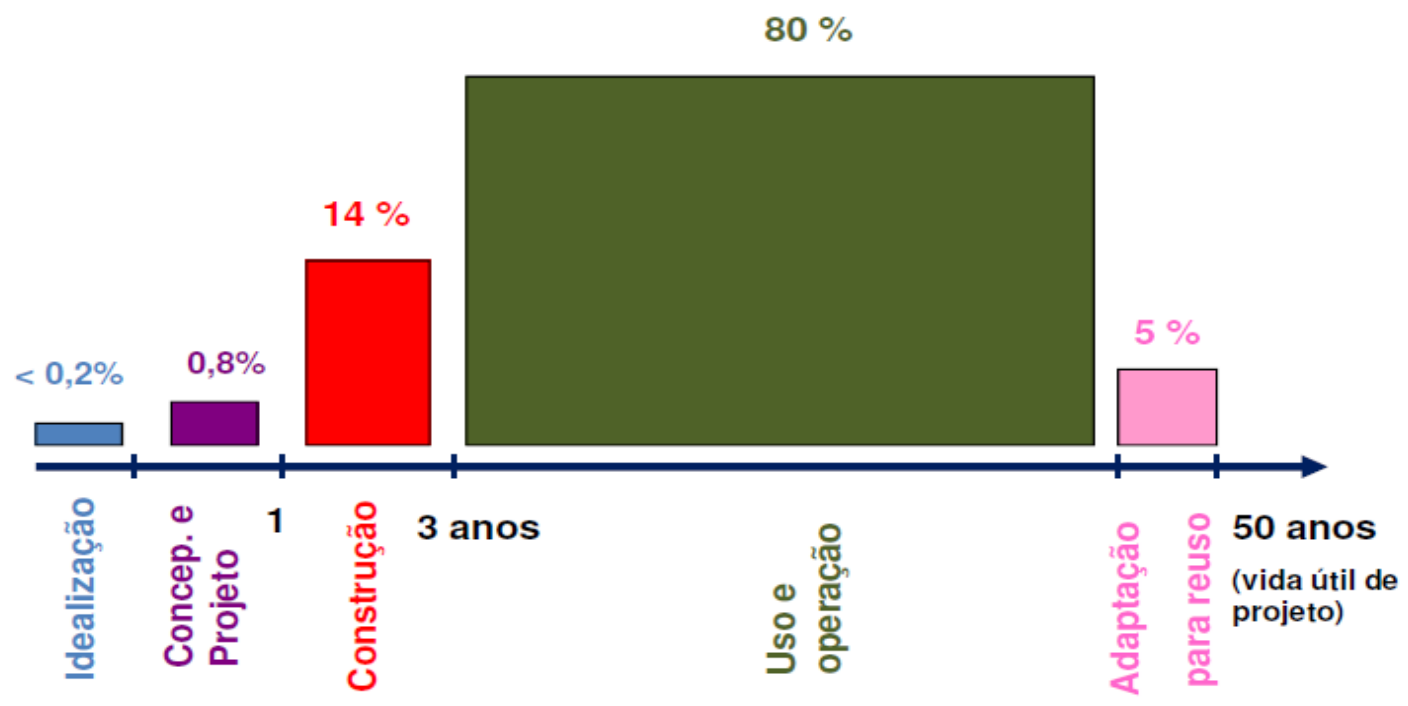

Figura 4: Custo total de um edifício comercial em 50 anos- vida útil de projeto (CEOTTO, 2008)

Segundo Ceotto (2008) de $80 \%$ a $100 \%$ desses impactos são definidos durante a idealização e concepção de projeto (etapas de projeto). O gráfico contido na Figura 5 a seguir ilustra como essas etapas são fundamentais para o adequado andamento e finalização das etapas seguintes.

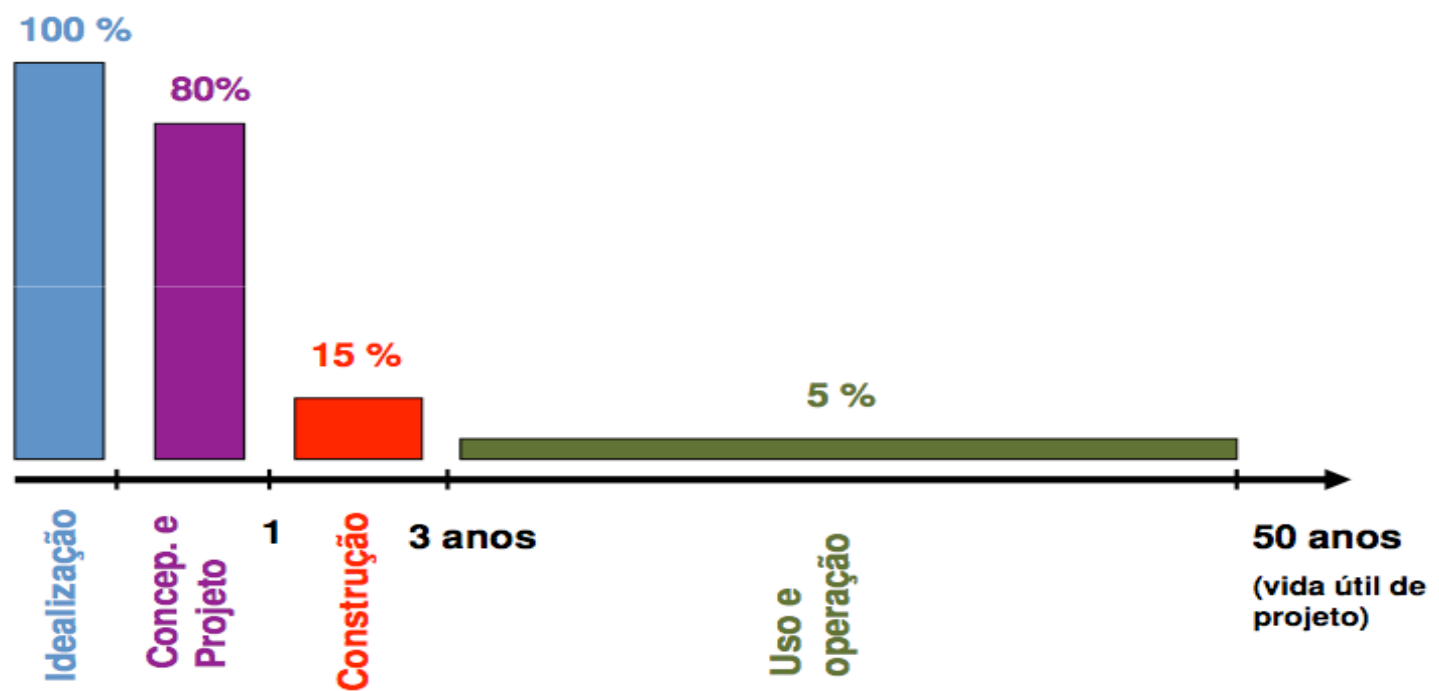

Figura 5: Possibilidade de interferência no custo total de um edifício em 50 anos (CEOTTO, 2008) 
Considerando-se os dados apresentados acima, explica-se melhor porque no contexto da sustentabilidade na Arquitetura e Urbanismo, dimensão ambiental, existe uma ênfase maior nas áreas de conforto, materiais e conservação de energia e recursos naturais. Ou seja, estas áreas concentram as maiores possibilidades de contribuição direta do arquiteto e urbanista com a sustentabilidade, pois são as áreas mais intimamente relacionadas aos maiores impactos identificados nos espaços urbanos. Como reflexo disto, tanto a dimensão ambiental quanto as áreas citadas também têm sido as mais exploradas pelo mercado, em pesquisas e pelo ensino.

Para Keeler e Burke (2009, p.22), o objetivo básico da sustentabilidade deve ser estabelecido já na idealização do projeto, o que resulta em metas significativas que permitem avaliar as opções e o progresso alcançados. Ao invés de prescrever soluções específicas, esse objetivo deve estipular metas mensuráveis para o desempenho da edificação.

Com relação às decisões de projeto, Norman Foster (2003, pg.2) destaca que, ao mesmo tempo em que sua equipe de projeto explora as mais recentes tecnologias para promover o conforto ambiental e a sustentabilidade, também busca inspiração para soluções de projeto em tradições esquecidas, como o uso da ventilação natural, ou soluções para refletir a luz natural em um espaço interior, por exemplo.

Para Sobreira (2009), a essência da sustentabilidade está nas soluções passivas (ao invés da dependência de novas tecnologias); na flexibilidade do projeto; na utilização de técnicas construtivas adaptadas à cultura local; na adequação ao entorno urbano; na utilização de materiais locais.

Portanto, para a concepção de obras sustentáveis, torna-se necessário, desde as etapas de projeto: a adoção de partidos arquitetônicos mais racionais e adaptados ao clima local, ou seja implantação e orientação da edificação de forma adequada, adotando soluções de ventilação, proteção solar e iluminação natural compatíveis com clima e relevo do terreno; o emprego de materiais de construção próprios da região, que atendam ao conforto da edificação, menos prejudiciais ao meio ambiente e de alta durabilidade; o incentivo à utilização de tecnologias menos impactantes ao meio ambiente e que possibilitem a obtenção de conforto; a eficiência energética, economia e reuso de água e de materiais; e 
direcionamento à reciclagem de resíduos; dentre outras ações que visem o atendimento da sustentabilidade das obras e entorno.

Sobre a integração com outras disciplinas, o Guidelines on Education Policy for Sustainable Built Environments (UNEP, 2010) destaca a relevância da participação em projetos sustentáveis de outros cursos da área do ambiente construído, das ciências naturais, ou mesmo das ciências sociais, incluindo as atividades de ensino e pesquisa, constituindo um projeto integrado. A iniciativa garante a compreensão holística da sustentabilidade e evidencia o caráter interdisciplinar e multidisciplinar do tema.

Segundo Andrade et al (2013) pode-se listar como pontos positivos da integração entre disciplinas no ensino da graduação a afinação do senso crítico dos estudantes para lidar com diferentes dimensões nas decisões de projeto, não privilegiando um tema em detrimento de outros, e a cristalização de conhecimentos especializados na experiência de projeto, mais duradoura e palpável.

Segundo o EDUCATE (2011) as metodologias pedagógicas devem se mover para fomentar o pensamento crítico e holístico, a aprendizagem ao longo da vida e fazendo multi, intra-, trans-, e interdisciplinares conexões sistêmicas entre domínios cognitivos aparentemente díspares.

Como conclusão, pode-se dizer que a sustentabilidade pede por mudanças no modelo de ensino atual, a fim de abordá-la de forma mais eficaz. Isto significa que a mudança deve ocorrer tanto nos planos de ensino e currículos atuais quanto nos projetos político pedagógicos dos cursos.

\subsection{AVALIAÇÃO CURRICULAR: O PROJETO EDUCATE}

Como já citado, uma das importantes iniciativas internacionais que vêm impactando os currículos e métodos de ensino de diversas universidades europeias são as provenientes do EDUCATE - Environmental Design in University Curricula and Architectural Training in Europe. O EDUCATE (2012 a) é um grupo formado por pesquisadores de universidades do Reino Unido, Bélgica, Alemanha, Itália, Espanha e Hungria, com inserção frequente de novos países, com o objetivo principal de inserir o projeto sustentável como prioridade na formação de arquitetos. 
De acordo com o EDUCATE (2012), seria errado supor que os educadores apresentam uma única interpretação da agenda de sustentabilidade e seu impacto sobre o ensino e a aprendizagem. E isto não surpreende dado que mesmo o conceito central tem suscitado várias centenas de definições, e iniciou esforços múltiplos voltados a métodos de ensino e normas nacionais e internacionais. Tem, no entanto, sido discutido que há valor em explorar a evolução dos currículos e respostas pedagógicas no esforço para interrogar, interpretar e integrar os mais representativos conceitos na sustentabilidade.

Considerando que as análises curriculares desenvolvidas nesta dissertação de mestrado foram em grande parte baseadas no método desenvolvido pelo EDUCATE (2011), torna-se necessário evidenciar quatro ações prioritárias definidas pelo grupo para o alcance da sustentabilidade ambiental na Arquitetura e Urbanismo e que foram tomados como referência nas análises realizadas nos cursos participantes do projeto. O EDUCATE aponta que devem ser consideradas na concepção, construção e operação de edificações, bem como na definição dos conteúdos programáticos das escolas de arquitetura, as seguintes prioridades para alcance da sustentabilidade ambiental:

1. Melhorar a qualidade de vida: melhorar o conforto interno e externo (térmico, visual, acústico e qualidade do ar), saúde e bem-estar, ao mesmo tempo, controlando a relação entre os espaços públicos e privados.

2. Diminuir demanda e o consumo de energia: minimizar a demanda de energia durante a construção e operação para refrigeração, aquecimento, ventilação, iluminação e equipamentos, diminuindo também o consumo de energia no transporte, incorporado nos produtos; sempre que possível, promover a utilização de fontes renováveis de energia.

3. Otimizar a utilização de materiais e outros recursos: aproveitar as propriedades e fontes de cada material, observando a disponibilidade de recursos, dando preferência ao uso de materiais renováveis; reciclagem e reutilização de produtos; redução do consumo de água; reaproveitamento de água, etc.

4. Minimização de resíduos: reduzir os resíduos de construção e demolição através de estratégias de projeto adequadas para desmontagem; minimizar o desperdício doméstico; fornecer infraestrutura para a reciclagem e triagem; etc. 
Logo, torna-se também importante para uma estruturação mais objetiva e analítica das informações coletadas, verificar os conteúdos constantes no Quadro 3 que delimitam os temas abrangidos pela sustentabilidade ambiental nos currículos de Arquitetura e Urbanismo. Os temas relacionados, foram organizados em campos, categorias e grupos, sendo que, de acordo com o EDUCATE (2011), o conteúdo de cada grupo ainda pode ser desmembrado em uma nova série de temas. Por exemplo, Iluminação Natural poderia ainda ser desmembrada em Geometria Solar, Lentes prismáticas, etc.

A seguir, serão descritas algumas etapas da metodologia utilizada pelo EDUCATE para análise curricular que serviram como referência para as análises desenvolvidas nesta dissertação de mestrado.

A primeira etapa do trabalho do EDUCATE consistiu na análise e consolidação do estado da arte da sustentabilidade nos currículos do ensino superior em Arquitetura e Urbanismo de diversas partes do mundo, principalmente da Europa. Tal etapa tinha dentre seus principais objetivos consolidar um panorama internacional em termos da abordagem da sustentabilidade no ensino acadêmico da atualidade. Desta forma, de cada currículo foram levantados e analisadas 10 informações relevantes para a classificação e compreensão do mesmo:

- Nome, duração e título emitido pelo curso.

- Órgão responsável pelo reconhecimento do curso e por regulamentar a atuação profissional.

- Objetivos educacionais

- Breve descrição do curso

- Estrutura curricular do curso

- Resultados esperados

- Projeto sustentável na estrutura curricular

- Integração do projeto sustentável com o ateliê de projetos

- Pontos fortes e oportunidades

- Resumo dos critérios para concessão de licença para atuação profissional

Esta etapa foi realizada através da análise das estruturas curriculares, ementas, métodos de ensino, critérios de avaliação, etc., nas instituições parceiras e também em outras organizações acadêmicas na Europa e fora dela, de modo a facilitar a sistematização 
do panorama do ensino atual e a melhor orientação para o desenvolvimento de uma estrutura curricular eficiente na incorporação da sustentabilidade ambiental na formação acadêmica do arquiteto (EDUCATE ,2012 d).

Para a realização deste levantamento também foi necessário levantar as publicações oficiais das instituições acadêmicas selecionadas (como sites, anuários, publicações pedagógicas, artigos em periódicos, conferências e trabalhos de alunos, etc.), além de um diagnóstico direto de acadêmicos da instituição através de entrevistas e questionários (EDUCATE, $2012 \mathrm{~d}$ ).

A etapa seguinte consistiu em analisar algumas das características do ensino de grande relevância na formação do arquiteto e urbanista com foco na sustentabilidade. Procurou-se identificar bons métodos de ensino a partir de currículos consolidados, com o objetivo de esclarecer os pontos fortes e oportunidades de integração de projeto sustentável nas diferentes metodologias pedagógicas e estruturas curriculares.

Dentre diversos fatores, a investigação tem sido baseada, principalmente, na análise da relação entre as diferentes áreas disciplinares que compõem um curso, de modo a enfatizar:

a) O nível de integração (se houver) entre disciplinas que abordam a sustentabilidade, com disciplinas de projeto em ateliê - conforme diagrama explicativo da Figura 6.

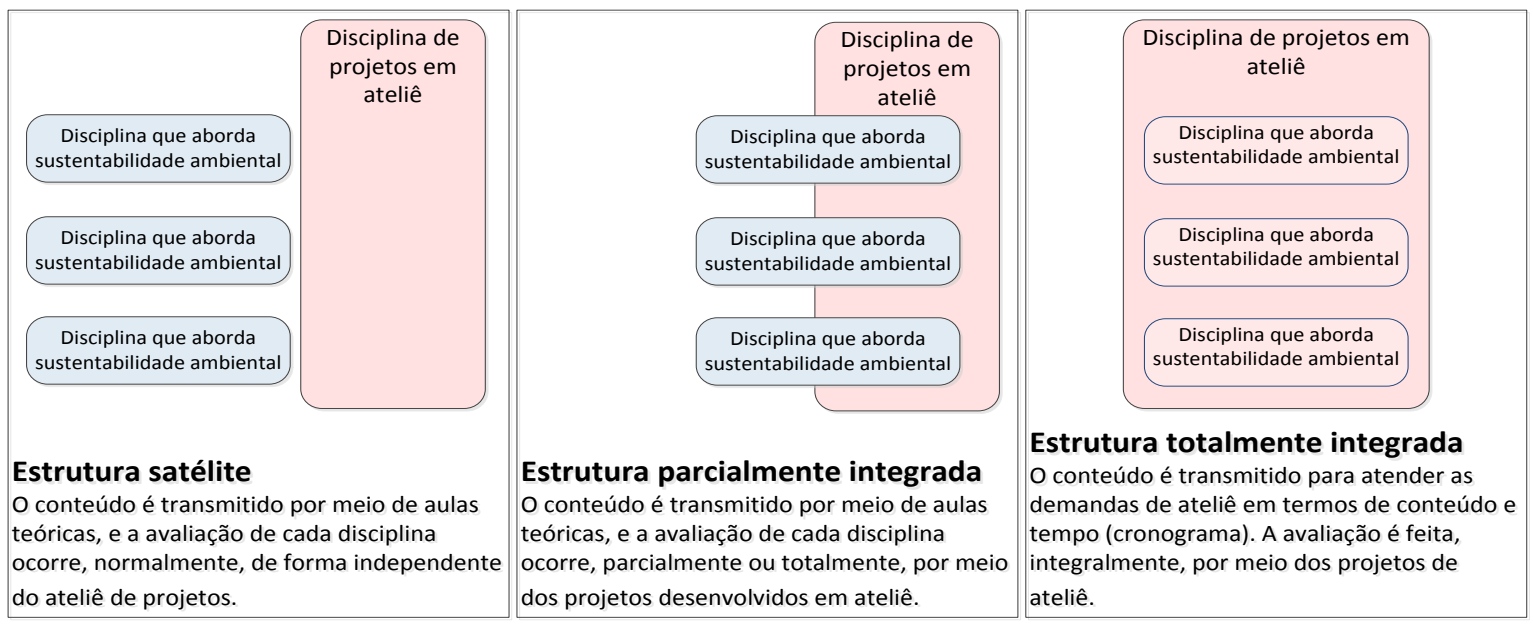

Figura 6: Exemplo de diagrama de análise do nível de integração entre disciplinas no currículo (Adaptado de EDUCATE, 2011) 
b) A visualização da carga horária atribuída a cada área disciplinar por período do curso - conforme gráfico contido na Figura 7.

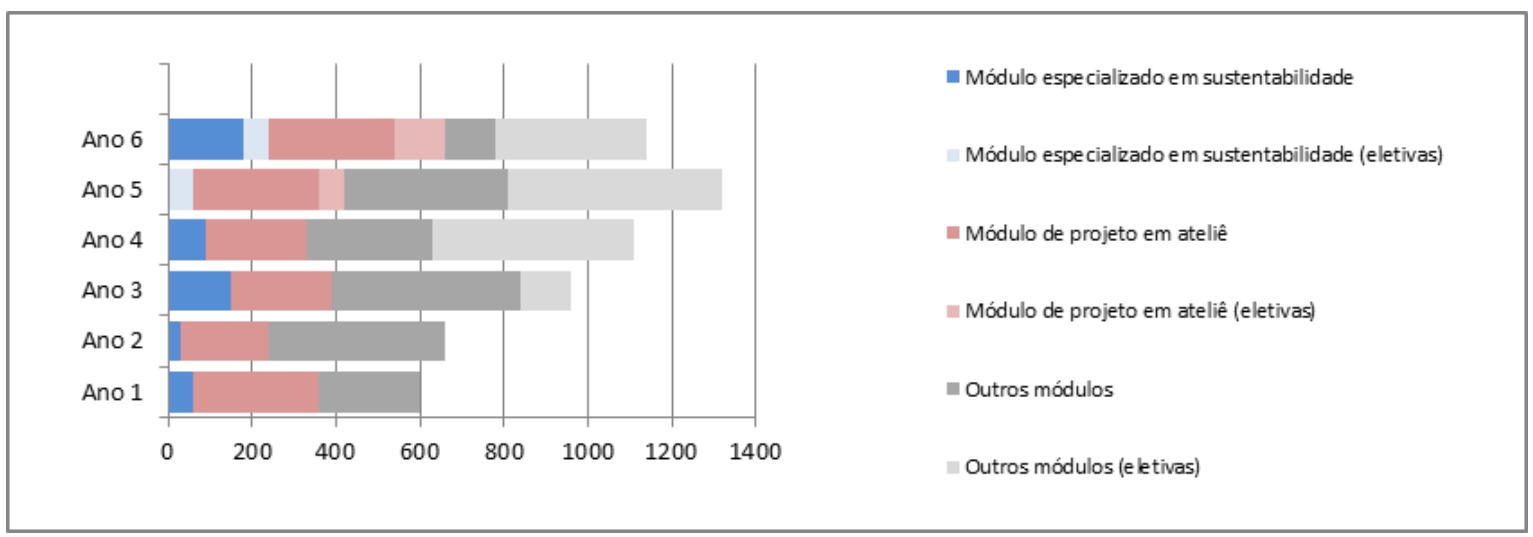

Figura 7: Exemplo de gráfico de horas-aula por tipo de disciplina e etapa do curso (Adaptado de EDUCATE, 2011)

Para a elaboração do diagrama, exemplificado na Figura 6, primeiramente identificaram-se as disciplinas especializadas (que abordam a sustentabilidade representadas pela cor azul); disciplinas de projeto em ateliê (que tratam do projeto arquitetônico, urbanístico ou planejamento urbano - representadas pela cor rosa); e outras disciplinas (que abordam os demais conteúdos - representadas pela cor cinza).

Posteriormente, foi investigado o nível de integração de cada disciplina especializada com as disciplinas de projeto em ateliê (práticas). Este aspecto, de acordo com o EDUCATE (2012 a), é de grande importância, pois trata da oportunidade de se colocar em prática e em concordância com outros conhecimentos, os conceitos absorvidos pelos alunos nas aulas teóricas das disciplinas especializadas, corroborando com a formação de um profissional que aplica na prática os conhecimentos em sustentabilidade.

Para a análise dessa integração entre disciplinas, consideram-se os seguintes aspectos (EDUCATE, 2012 a):

a) conteúdo: descreve-se sistematicamente o conteúdo apresentado nas disciplinas, onde informações específicas sobre os temas de sustentabilidade são fornecidos;

b) métodos de ensino: identificam-se sistematicamente métodos e ferramentas de ensino utilizadas como, por exemplo, palestras, trabalhos integrados com projetos, seminários, workshops, vídeo-aulas, etc; 
c) ferramentas pedagógicas: identificam-se técnicas didáticas e destacam-se métodos de aprendizagem baseada em problemas ou aprendizagem experimental que pode ser em laboratório físico (através de recursos como heliodon, céu artificial, visitas, etc) e/ou laboratório virtual (computação, ferramentas de simulação, softwares especializados e ferramentas de e-learning, etc);

d) avaliação: Identifica-se se a avaliação é feita por meio de prova (oral ou escrita), exercícios, trabalhos práticos de projeto na própria disciplina, ou trabalhos práticos integrados a outras disciplinas, de projeto ou de outros cursos, dentre outros.

Por fim, após a análise de todas as disciplinas, separadas por períodos, ano, ou fase (conforme a particularidade de cada escola), são elaborados, a partir do diagrama explicativo da Figura 6, diagramas curriculares para cada curso analisado.

O grupo EDUCATE (2012 d) analisou 62 (sessenta e dois) currículos de escolas de arquitetura de 26 (vinte e seis) países, onde conseguiu identificar tendências que apontam para cinco modelos paradigmáticos de estrutura curricular, tendo como foco da análise os níveis de integração entre disciplinas especializadas em sustentabilidade ambiental e projetos em ateliê.

A Figura 8 demonstra graficamente cada um dos cinco modelos paradigmáticos de estrutura curricular identificados, estando os mesmos detalhados, de forma sucinta, no Quadro 4.

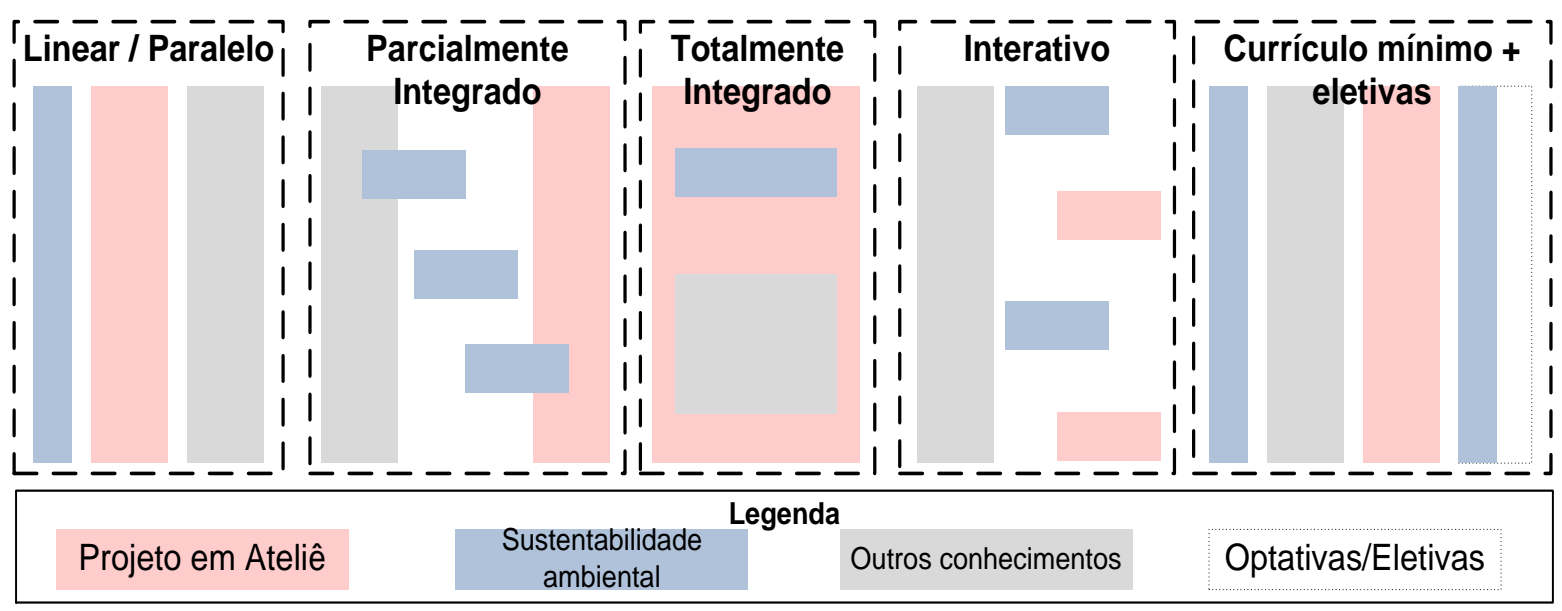

Figura 8: Modelos paradigmáticos das estruturas curriculares de ensino da Arquitetura e Urbanismo (adaptado de EDUCATE, 2012 a) 
Quadro 4: Descrição sucinta dos modelos paradigmáticos das estruturas curriculares de ensino da Arquitetura e Urbanismo (adaptado de EDUCATE, 2012 a) 


\begin{tabular}{|c|c|c|c|c|c|}
\hline & Linear/Paralelo & $\begin{array}{l}\text { Parcialmente } \\
\text { Integrado }\end{array}$ & $\begin{array}{c}\text { Totalmente } \\
\text { integrado }\end{array}$ & Interativo & $\begin{array}{c}\text { Currículo mínimo + } \\
\text { eletivas }\end{array}$ \\
\hline Conteúdo & $\begin{array}{l}\text { O conteúdo é } \\
\text { repassado de forma } \\
\text { independente em } \\
\text { cada disciplina. }\end{array}$ & $\begin{array}{l}\text { O conteúdo é } \\
\text { desenvolvido em } \\
\text { disciplinas } \\
\text { específicas, ou } \\
\text { parcialmente } \\
\text { integrado ao } \\
\text { conteúdo de outras } \\
\text { disciplinas. }\end{array}$ & $\begin{array}{l}\text { Neste modelo, o } \\
\text { conteúdo evolui a } \\
\text { partir das } \\
\text { necessidades } \\
\text { demandadas pelo } \\
\text { ateliê de projetos, } \\
\text { sendo este } \\
\text { concebido como um } \\
\text { espaço de trabalho } \\
\text { interdisciplinar. }\end{array}$ & $\begin{array}{l}\text { O conteúdo, ao } \\
\text { longo do currículo, } \\
\text { está estruturado em } \\
\text { fases cíclicas } \\
\text { interdependentes, } \\
\text { onde o tema } \\
\text { abordado em uma } \\
\text { disciplina é utilizado } \\
\text { em algum trabalho } \\
\text { prático de outra, que } \\
\text { demandará novos } \\
\text { conhecimentos. }\end{array}$ & $\begin{array}{l}\text { Este modelo é } \\
\text { caracterizado pela } \\
\text { oferta de grande } \\
\text { número de } \\
\text { disciplinas optativas } \\
\text { ou eletivas e um } \\
\text { currículo mínimo } \\
\text { padrão. O conteúdo } \\
\text { é desenvolvido de } \\
\text { forma independente } \\
\text { em cada disciplina. }\end{array}$ \\
\hline $\begin{array}{l}\text { Método de } \\
\text { ensino }\end{array}$ & $\begin{array}{l}\text { O conteúdo é } \\
\text { transmitido através } \\
\text { de aulas expositivas } \\
\text { ou palestras. }\end{array}$ & $\begin{array}{l}\text { O conteúdo é } \\
\text { transmitido através } \\
\text { de aulas expositivas } \\
\text { ou palestras. Os } \\
\text { temas das palestras } \\
\text { podem abordar a } \\
\text { temática associada a } \\
\text { outros } \\
\text { conhecimentos. }\end{array}$ & $\begin{array}{l}\text { O conhecimento é } \\
\text { transmitido por } \\
\text { palestras, aulas } \\
\text { práticas, monitoria } \\
\text { ou } \\
\text { acompanhamento } \\
\text { individual, para } \\
\text { atender as } \\
\text { demandas do ateliê } \\
\text { de projetos com } \\
\text { relação ao conteúdo } \\
\text { e tempo. }\end{array}$ & \begin{tabular}{|l|} 
O conteúdo é \\
transmitido através \\
de aulas expositivas, \\
palestras e aulas \\
práticas. Os \\
conteúdos \\
transmitidos em um \\
ciclo são usados para \\
adquirir as \\
competências do \\
seguinte e o \\
conhecimento é \\
aprofundado \\
progressivamente. \\
\end{tabular} & $\begin{array}{l}\text { O conteúdo é } \\
\text { transmitido através } \\
\text { de aulas expositivas } \\
\text { ou palestras. }\end{array}$ \\
\hline Avaliação & $\begin{array}{l}\text { A avaliação é feita } \\
\text { por meio de } \\
\text { exames/provas ou } \\
\text { trabalhos } \\
\text { acadêmicos } \\
\text { individuais em cada } \\
\text { disciplina }\end{array}$ & $\begin{array}{l}\text { A avaliação é feita } \\
\text { por meio de exames } \\
\text { específicos ou, às } \\
\text { vezes, em trabalhos } \\
\text { integrados à outras } \\
\text { disciplinas. }\end{array}$ & \begin{tabular}{|l|} 
A avaliação é feita \\
através de trabalhos \\
práticos, onde \\
agregam-se à \\
avaliação novos \\
conhecimentos/tem \\
as conforme a \\
evolução do curso. \\
\end{tabular} & $\begin{array}{l}\text { A avaliação é feita } \\
\text { por meio de exames } \\
\text { ou trabalhos práticos } \\
\text { específicos para cada } \\
\text { disciplina. }\end{array}$ & $\begin{array}{l}\text { A avaliação é feita } \\
\text { por meio de exames } \\
\text { ou trabalhos práticos } \\
\text { específicos para cada } \\
\text { disciplina. }\end{array}$ \\
\hline \begin{tabular}{|l} 
Outros \\
diferenciais
\end{tabular} & $\begin{array}{l}\text { Essa estrutura } \\
\text { propicia uma visão } \\
\text { clara e organizada do } \\
\text { programa de } \\
\text { estudos, } \\
\text { possibilitando o } \\
\text { acréscimo de } \\
\text { complexidade dos } \\
\text { temas ao longo do } \\
\text { curso. Contudo, a } \\
\text { falta de integração } \\
\text { faz com que os } \\
\text { conhecimentos } \\
\text { sejam percebidos em } \\
\text { separados do } \\
\text { projeto. }\end{array}$ & $\begin{array}{l}\text { Essa estrutura } \\
\text { permite, } \\
\text { parcialmente, a } \\
\text { prática dos } \\
\text { conhecimentos } \\
\text { especializados em } \\
\text { outras áreas, como } \\
\text { em projetos, além de } \\
\text { permitir estudos } \\
\text { aprofundados } \\
\text { específicos. O } \\
\text { modelo dá } \\
\text { oportunidade para } \\
\text { investigações em } \\
\text { diferentes áreas } \\
\text { disciplinares. }\end{array}$ & $\begin{array}{l}\text { A estrutura permite } \\
\text { a aplicação prática } \\
\text { dos conhecimentos, } \\
\text { mas deve ser } \\
\text { cuidadosamente } \\
\text { gerenciada e } \\
\text { acompanhada para } \\
\text { evitar repetições e } \\
\text { conflitos. A interação } \\
\text { de todo corpo } \\
\text { docente é essencial. } \\
\text { As diferentes áreas } \\
\text { disciplinares } \\
\text { convergem na } \\
\text { concepção dos } \\
\text { projetos. }\end{array}$ & $\begin{array}{l}\text { Há uma clara } \\
\text { interdependência } \\
\text { entre as disciplinas } \\
\text { especializadas e as } \\
\text { disciplinas de } \\
\text { projeto, propiciando } \\
\text { o aproveitamento de } \\
\text { conhecimentos e a } \\
\text { evolução da } \\
\text { complexidade } \\
\text { durante o curso. }\end{array}$ & $\begin{array}{l}\text { O curso se } \\
\text { caracteriza por um } \\
\text { elevado número de } \\
\text { disciplinas de livre } \\
\text { escolha. A natureza } \\
\text { multi-disciplinar } \\
\text { permite a reflexão } \\
\text { do aluno sob } \\
\text { diferentes pontos de } \\
\text { vista. A estrutura } \\
\text { também permite a } \\
\text { especialização } \\
\text { conforme as } \\
\text { afinidades do aluno. }\end{array}$ \\
\hline $\begin{array}{l}\text { Exemplos } \\
\text { de } \\
\text { currículos }\end{array}$ & $\begin{array}{l}\text { Universidade de São } \\
\text { Paulo- USP (Brasil) }\end{array}$ & $\begin{array}{l}\text { Technische } \\
\text { Universitat } \\
\text { Muenchen } \\
\text { (Alemanha) e } \\
\text { Politécnico de Milão } \\
\text { (Itália) }\end{array}$ & $\begin{array}{l}\text { Universidad de A } \\
\text { Coruna (Espanha) }\end{array}$ & $\begin{array}{l}\text { Universite } \\
\text { Catholique de } \\
\text { Louvain (Bélgica) }\end{array}$ & $\begin{array}{l}\text { University of Delft } \\
\text { (NL), University of } \\
\text { California - Berkeley } \\
\text { (EUA) Ecole } \\
\text { Polytechnique } \\
\text { Federal de Lausanne } \\
\text { (CH) }\end{array}$ \\
\hline
\end{tabular}


Como pode ser evidenciado no Quadro 4, cada um dos cinco modelos paradigmáticos de estrutura curricular possui particularidades. Lembramos que, a partir da identificação dos modelos acima, o EDUCATE pôde propor estratégias voltadas ao aprimoramento do ensino da sustentabilidade para cada realidade, e estas estratégias são descritas no Criteria for Professional Qualification (EDUCATE ,2012 a).

O EDUCATE (2012 a) entende que os currículos das universidades podem e devem manter suas diferenças, contribuindo para a evolução das práticas pedagógicas na arquitetura. Contudo, ele procura nortear as adequações que sejam identificadas como potencializadoras do ensino. Logo, as propostas apresentadas pelo grupo não deverão ser consideradas como substitutas para as atuais estruturas de ensino, mas podem orientar melhorias:

De forma genérica, as ações sugeridas pelo EDUCATE são as seguintes:

\section{Desenvolver conexões entre aulas teóricas e prática em ateliê de projeto}

As conexões para uma abordagem multi/inter/transdisciplinar do projeto, bem como para fomentar trabalho em equipe e comunicação, podem ser promovidas por palestras e projetos sustentáveis, possibilitando uma ligação direta entre princípios teóricos e suas aplicações práticas. A pedagogia pode incorporar seminários e workshops diretamente relacionados com estratégias ambientais. Estudos de caso, visitas a canteiros de obras e palestras dadas por profissionais convidados podem conciliar os vários domínios disciplinares do currículo.

\section{Promover uma abordagem baseada em pesquisa analítica e holística para o} projeto

Além da intuição e criatividade, o projeto e a construção do ambiente também devem ser fundamentados em metodologia sistemática e holística. A influência de cada opção de projeto deve ser medida em relação ao meio ambiente em geral e bem-estar dos usuários. Uma abordagem analítica e baseada em pesquisas deve ser propiciada aos estudantes ao longo do ensino. Os alunos deverão ser capazes de apreciar criticamente dados, avaliar argumentos, fazer julgamentos, elaborar e verificar hipóteses e formular perguntas apropriadas dentro de seus projetos. 
3. Aumentar a competência em sustentabilidade nas várias fases do conteúdo programático

Os princípios da sustentabilidade não devem ser apenas vistos como uma "especialização", separada e com conteúdos transmitidos de forma independente, mas devem ser parte integrante do currículo como uma inspiração eficaz para todo processo de projeto. Esta abordagem pedagógica deve avançar para a integração das disciplinas especializadas com o ateliê de projetos, onde o conhecimento teórico fornece um suporte para o desenvolvimento do projeto prático.

\section{Promover a posição central do ateliê de projeto em todo o currículo}

A estreita relação entre palestras e ateliê de projeto deve incentivar o pensamento crítico e criativo, iniciando uma série de projetos que evolui ao longo do currículo devidamente organizado. Os alunos devem ser incentivados a desenvolver um nível significativo de habilidades, onde as noções são sintetizadas dentro do projeto, fórum natural para exploração criativa e aplicações do conhecimento. A posição central do ateliê de projetos poderia dar a oportunidade de coordenar a competência adquirida e desenvolver uma visão holística.

\section{Promover a aprendizagem centrada no estudante (incluindo o uso de} ferramentas computacionais)

A colaboração, o foco na resolução de problemas ou na aprendizagem experimental é parte importante para a educação em sustentabilidade. Neste contexto, informação, tecnologias de comunicação e e-learning oferecem oportunidades significativas para motivar os alunos através de trocas interativas com tutores e colegas, colaboração entre especialistas de áreas distintas (fundamental para um projeto integrado) e proporcionar acesso a material didático e troca de informações. Ambientes virtuais de projeto e ferramentas como o BIM (Modelagem de Informações Construtivas) podem expandir os limites da aprendizagem para além da instituição e desenvolver habilidades para trabalho em equipe, apoiando o debate e comunicação. 
Para o EDUCATE (2012 a) qualquer investigação sobre como o projeto sustentável pode ser incorporado, integrado e transferido aos currículos do ensino superior entre os países europeus e não europeus precisa considerar a formação em discussão, as diretrizes curriculares vigentes, benchmarking ${ }^{2}$ sobre o assunto, critérios de validação do curso e especificidades locais. Toda a contextualização educacional e benchmarking do assunto, contudo, não se destinam à especificação de um currículo detalhado, eles devem permitir a flexibilidade e inovação curricular e estimular a discussão acadêmica sobre os conteúdos programáticos novos e existentes dentro do contexto geral.

O EDUCATE acredita que há a possibilidade de uma pluralidade de abordagens que podem ser adotadas no projeto de arquitetura sustentável, tornando difícil formular uma estrutura "ideal" de currículo. Portanto, o grupo acredita que esta resposta deve vir de metodologias pedagógicas específicas já aplicadas, direcionadas aos resultados da aprendizagem.

Algumas das estratégias orientadas pelo EDUCATE já estão sendo implementadas em cursos de arquitetura de universidades europeias ${ }^{3}$. Estas estratégias englobam ações de caráter diverso, baseado em cada modelo de estrutura curricular identificado, e se desenvolvem com foco em vários aspectos do ensino, ou seja, ora no currículo, ora em atividades complementares, ora pelo uso de novas ferramentas, dentre outros. Contudo, as ações que vêm sendo desenvolvidas têm apresentado resultados considerados positivos pelos professores e alunos participantes desse projeto. Estes estão detalhados no relatório Results of Course and Curriculum Development (EDUCATE, 2012c). Neste documento são evidenciados resultados através de trabalhos dos alunos, pesquisas em desenvolvimento, depoimentos e relatórios de especialistas e professores dos cursos.

\footnotetext{
${ }^{2}$ Benchmarking: É o processo contínuo e sistemático que permite a comparação das performances das organizações e respectivas funções ou processos face ao que é considerado "o melhor nível", visando não apenas a equiparação dos níveis de performance mas também a sua superação.

${ }^{3}$ University of Nottingham, (Reino Unido); Architectural Association School of Architecture (Reino Unido); Catholic University of Louvain (Bélgica); Technical University of Munich (Alemanha); University of Rome La Sapienza (Itália); Budapest University of Technology and Economics, (Hungria), dentre outras.
} 


\section{MÉTODO}

O presente capítulo apresenta o método desenvolvido para alcance dos objetivos geral e específicos traçados para este trabalho Inicialmente, apresenta o método de identificação dos cursos de Arquitetura e Urbanismo que apresentaram os melhores resultados no ensino da sustentabilidade por meio de eventos voltados ao tema e, posteriormente, apresenta o método de levantamento de dados dos cursos selecionados, definição dos critérios de análise e explica como se deu a sistematização das informações coletadas.

Logo, para alcançar o objetivo geral deste trabalho de fornecer subsídios para o ensino da sustentabilidade nos cursos de Arquitetura e Urbanismo no Brasil, a partir dos projetos político pedagógicos, currículos e planos de ensino, procederam-se quatro etapas conforme ilustra o fluxograma da Figura 9, a seguir: 


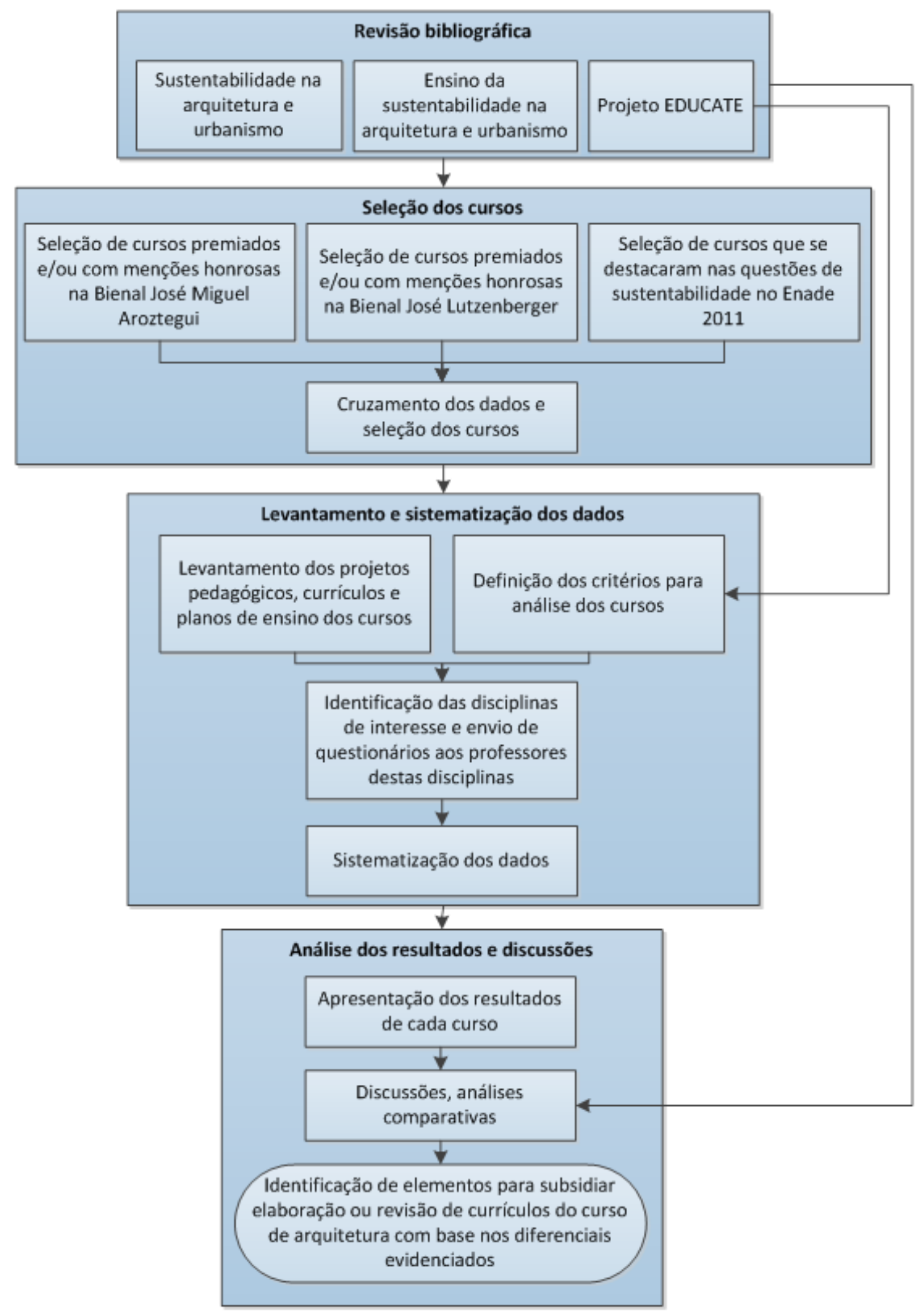

Figura 9: Metodologia adotada no trabalho 
Na primeira etapa, já apresentada nos Capítulos 2 e 3 desta dissertação de mestrado, procedeu-se uma revisão bibliográfica que auxiliou numa melhor compreensão sobre a amplitude, delimitações e importância da temática da sustentabilidade na Arquitetura e Urbanismo, na elucidação sobre o ensino dessa temática para arquitetos e urbanistas ao longo dos anos, além de um panorama sobre o estado da arte do ensino, considerando escolas de arquitetura de diversos países. A revisão bibliográfica auxiliou, também, na orientação da metodologia de análise desenvolvida, pois esta foi baseada inicialmente no trabalho desenvolvido pelo grupo EDUCATE, que analisou currículos de escolas de arquitetura de vários países com foco na abordagem da sustentabilidade.

Na segunda etapa, para a seleção dos cursos brasileiros que seriam analisados, foram selecionados os cursos de Arquitetura e Urbanismo que apresentaram os melhores resultados considerando a temática da sustentabilidade. Para a seleção, foram consideradas Instituições que se destacaram no: Enade; Bienal José Miguel Aroztegui e; Bienal de Sustentabilidade José Lutzenberger. Ao final do levantamento e análise dos eventos citados, foram selecionadas cinco (5) cursos de Arquitetura e Urbanismo nacionais. O procedimento está melhor detalhado na seção 5.1 desta dissertação de mestrado.

$\mathrm{Na}$ terceira etapa, para análise específica dos cinco (5) cursos selecionados, foram definidos, a partir da revisão bibliográfica realizada, os critérios de análise mais apropriados para verificação do ensino da sustentabilidade. $\mathrm{Na}$ sequência, foram levantados os projetos político pedagógicos dos cursos (currículos, estruturas curriculares), planos de ensino (ementas, objetivos, conteúdos, métodos, avaliação) e enviados questionários aos professores das disciplinas de interesse para levantamento dos dados necessários à análise. Após recebimento, iniciou-se trabalho de sistematização para possibilitar a análise das informações. Este procedimento é detalhado na seção 5.2 desta dissertação de mestrado.

$\mathrm{Na}$ quarta e última etapa, apresentaram-se os resultados das diversas análises que foram realizadas a partir dos dados levantados e através do cruzamento comparativo dos cursos, o que tornou possível identificar alguns diferenciais no ensino da sustentabilidade nos cursos brasileiros analisados que podem ser utilizados como subsídios para este ensino. Este procedimento está descrito no Capítulo 5. 


\subsection{SELEÇÃO DOS CURSOS}

Considerando que existiam 183 cursos de Arquitetura e Urbanismo no Brasil em 2011 (INEP, 2011), é razoável supor que tínhamos também uma grande diversidade no ensino ofertado. Logo, considerando que o objetivo deste trabalho é propor subsídios para o ensino da sustentabilidade, o caminho escolhido foi identificar diferenciais curriculares que possam ter influenciado em resultados positivos no ensino desta temática alcançado por alguns dos cursos de Arquitetura e Urbanismo do Brasil.

Portanto, para a seleção dos cursos que se destacaram no ensino da sustentabilidade, foram escolhidas as duas bienais de maior importância no contex to nacional com relação à sustentabilidade, Bienal José Miguel Aroztegui e Bienal de Sustentabilidade José Lutzenberger; e também verificado o desempenho dos alunos de Arquitetura e Urbanismo por meio do Enade 2011, considerando as questões da prova voltadas à sustentabilidade. Explica-se que o Enade do ano de 2011 foi escolhido como referência por apresentar os resultados mais recentes de provas de Arquitetura e Urbanismo já finalizados.

O critério utilizado para a seleção dos cursos foi a seleção das escolas de Arquitetura e Urbanismo que ficaram melhor colocadas, concomitantemente, em pelo menos dois dos três eventos considerados. Dessa forma, considerou-se que nesta seleção encontram-se os cursos cujos alunos teriam apreendido melhor os conteúdos englobados pela temática da sustentabilidade, visto que, tanto se verifica o domínio teórico dos conteúdos pelos alunos, através de algumas questões do Enade 2011, como a capacidade de aplicação dos conhecimentos sobre sustentabilidade na prática projetual, através dos projetos apresentados nas bienais escolhidas.

Desta forma, a seguir relacionam-se as principais considerações que levaram à escolha dos eventos citados como referência para a seleção dos cursos.

\subsubsection{Bienal José Miguel Aroztegui}

A Bienal José Miguel Aroztegui- Concurso Estudantil Latino-Americano de Arquitetura Bioclimática é promovida pelo Grupo de Conforto e Eficiência Energética da ANTAC e acontece sempre nos anos ímpares, desde 1999. O objetivo da Bienal é "promover e incentivar a incorporação das técnicas bioclimáticas na construção do habitat humano, visando otimizar sua qualidade ambiental e sua eficiência energética por meio do 
uso privilegiado de recursos naturais renováveis" (BIENAL JOSÉ MIGUEL AROZTEGUI, 1999).

Podem participar estudantes de qualquer curso de graduação relacionado ao ambiente construído e oferecido por instituição latino-americana.

Segundo a Bienal José Miguel Aroztegui (1999) a arquitetura bioclimática é aquela em que a qualidade ambiental e a eficiência energética são obtidas por meio do aproveitamento racional dos recursos da natureza, de modo a contribuir com o equilíbrio do ecossistema no qual está inserida, sendo que suas principais características são:

a) Adequação do espaço construído ao meio climático e às necessidades humanas.

b) Racionalização do consumo de energia.

c) Conforto ambiental proporcionado pelo uso otimizado de recursos renováveis.

Sobre o evento Bienal José Miguel Aroztegui, observam-se as seguintes características:

- abrangência (concurso aberto à participação de todos os cursos brasileiras, com participação inclusive de outros países - é concurso opcional e por isso depende do interesse e iniciativa da escola/alunos para a participação e direcionamento dos trabalhos).

- imparcialidade (é um concurso com participação de vários países, que já vem acontecendo há alguns anos e com supervisão da ANTAC, por isso acredita-se na sua seriedade).

- confiabilidade (Os estudantes enviam projetos arquitetônicos e /ou urbanísticos sem qualquer referência que permita identificar a autoria).

- especialização (é julgado por 3 profissionais distintos e possui áreas temáticas bem definidas para o julgamento, o que diminui o subjetivismo inerente à avaliação de projetos).

- temporalidade (não tem a característica de ser aplicado ao final do curso, porém é aplicado em um momento em que o aluno já é capaz de desenvolver o projeto definindo suas características mais fundamentais, no grau do produto exigido pelo concurso). 
- temática (aborda especificamente do tema em discussão neste trabalho, o que ainda possibilita a análise mais profunda voltada à capacidade de aplicação de aspectos da temática na prática projetual.)

Por tais características, a Bienal José Miguel Aroztegui foi escolhida como um dos instrumentos para verificação do aprendizado da sustentabilidade por alunos de cursos de Arquitetura e Urbanismo no Brasil.

O levantamento dos cursos de Arquitetura e Urbanismo brasileiros com maior número de trabalhos selecionados nas edições da Bienal Miguel Aroztegui, dentre trabalhos premiados, menções honrosas e trabalhos selecionados para a mostra itinerante será apresentado na Tabela 3, seção 5.1 desta dissertação de mestrado.

\subsubsection{Bienal de Sustentabilidade José Lutzenberger}

De acordo com a ANTAC (2012) a Bienal de Sustentabilidade José Lutzenberger tem como objetivo promover e incentivar a incorporação de produtos, processos e técnicas sustentáveis na produção do Ambiente Construído.

Podem concorrer, individualmente, ou em equipes, estudantes de qualquer escola de graduação e pós-graduação, ofertado por instituições latino-americanas de ensino superior, e profissionais de qualquer formação. A critério de cada escola, os projetos podem ser desenvolvidos no âmbito de disciplinas específicas, ou como atividade extracurricular.

O evento demonstra que, atualmente, a questão da sustentabilidade extrapola a dimensão ambiental, apresentando como princípios norteadores as dimensões: econômica, social, geográfica ou espacial, cultural e ecológica.

De acordo com ELECS (2011) os critérios e etapas de julgamento devem considerar os seguintes critérios:

" Grau de contribuição para o avanço da Sustentabilidade, através de Projetos, Produtos e Processos para um Ambiente Construído mais Sustentável;

- Criatividade das soluções;

- Originalidade;

- Adequação de custos; 
- Adequação ao contexto; $e$

• Qualidade de apresentação."

(ELECS, 2011, p.01)

Sobre a Bienal José Lutzenberger, observam-se as seguintes características:

- abrangência (concurso aberto à participação de todos os cursos brasileiros, com participação inclusive de outros países - porém é opcional e por isso depende do interesse e iniciativa da escola/alunos para a participação e direcionamento dos trabalhos).

- imparcialidade (é um concurso aberto a estudantes e profissionais de qualquer formação que já realizou 3 edições sob supervisão da ANTAC / ELECS, por isso acreditase na sua seriedade).

- confiabilidade (Os estudantes enviam projetos sem qualquer referência que permita identificar a autoria).

- especialização (é julgado por 3 profissionais distintos, inclusive multidisciplinares, e possui critérios de julgamentos bem focados nos aspectos da sustentabilidade, o que diminui o subjetivismo inerente à avaliação dos projetos).

- temporalidade (não tem a característica de ser aplicado ao final do curso, porém é aplicado em um momento em que o aluno já é capaz de desenvolver o projeto definindo suas características mais fundamentais, no grau do produto exigido pelo concurso).

- temática (aborda especificamente do tema em discussão neste trabalho, o que ainda possibilita a análise mais profunda voltada à capacidade de aplicação de aspectos da temática na prática projetual).

Por tais características, a Bienal de Sustentabilidade José Lutzenberger foi escolhida como um dos instrumentos para verificação do aprendizado da sustentabilidade por alunos de cursos de Arquitetura e Urbanismo no Brasil.

O levantamento dos cursos de Arquitetura e Urbanismo brasileiros com maior número de trabalhos selecionados nas edições da Bienal de Sustentabilidade José Lutzenberger, dentre trabalhos premiados, menções honrosas e trabalhos selecionados para a mostra itinerante será apresentado na Tabela 4, seção 5.1 desta dissertação de mestrado. 


\subsubsection{Enade}

O Exame Nacional de Desempenho dos Estudantes (Enade) é um dos procedimentos de avaliação do ensino superior no Brasil. Ele é realizado pelo Instituto Nacional de Estudos e Pesquisas Educacionais Anísio Teixeira (INEP), autarquia do governo brasileiro. Este exame é componente curricular obrigatório e aplicado trienalmente a todos os cursos de graduação do país, para os alunos ingressantes e concluintes do curso.

O Enade é voltado à avaliação das Instituições e também à avaliação dos cursos oferecidos. Para a avaliação dos cursos o exame busca identificar as condições de ensino oferecidas aos estudantes, em especial as relativas ao perfil do corpo docente, às instalações físicas e à organização didático-pedagógica e aferir o conhecimentos dos alunos. (INEP, 2011b).

Segundo o INEP (2011b), o exame tem como objetivos aferir o rendimento dos alunos no processo de aprendizagem com relação aos conteúdos programáticos constantes nas diretrizes curriculares, suas habilidades de ajustamento à evolução dos conhecimentos e competências para compreender temas exteriores ao âmbito específico da profissão.

Os instrumentos de avaliação do Enade são a prova presencial, questionários aplicados via internet e visitas in loco por comissões de especialistas.

São objetivos da avaliação de conhecimento dos alunos:

“- Contribuir para a avaliação dos cursos de graduação por meio da verificação das competências, habilidades e conhecimentos desenvolvidos pelos estudantes em sua formação, em consonância com características do perfil profissional da área;

- Aferir o desempenho dos estudantes no que se refere ao uso, síntese e integração de conhecimentos adquiridos ao longo do curso;

- Possibilitar aos cursos o acompanhamento dos resultados de suas ações pedagógicas;

- Avaliar comparativamente a formação oferecida pelas IES aos estudantes das respectivas áreas avaliadas."

(INEP, 2011a, p.01) 
Destaca-se que as informações geradas a partir do Enade são usadas por diversos públicos, dentre eles: Instituições de Ensino Superior -IES (dirigentes, coordenadores e estudantes), que podem usar as informações para analisar questões pedagógicas e reorientá-las, como é o caso deste trabalho.

O Enade é desenvolvido com o apoio técnico de comissões assessoras compostas por especialistas de notório saber, integrantes de IES públicas e privadas - da área específica e da formação geral (buscando contemplar as diversas regiões do país). Essas comissões são responsáveis pela determinação dos conteúdos a serem avaliados, bem como, pela elaboração de questões envolvendo situações-problema e estudos de casos.

Sobre o Enade, observam-se as seguintes características:

- abrangência (é obrigatório a todos os concluintes regulares dos cursos de Arquitetura e Urbanismo do Brasil).

- imparcialidade (é um procedimento de avaliação desenvolvido pelo governo federal com objetivo claro de caracterizar o ensino oferecido no país).

- confiabilidade (as provas de conhecimentos são presenciais, sem consulta e vigiadas, sendo aplicadas e avaliadas por instituições que com capacidade técnica comprovada).

- especialização (provas elaboradas e avaliadas por especialistas de notório saber, integrantes de IES públicas e privadas de todas as regiões do país).

- temporalidade (é aplicado ao final do curso de graduação, o que o torna mais fiel quanto à avaliação do rendimento dos alunos).

- temática (aborda o tema em discussão ao longo da prova - o que pôde ser verificado em análise prévia para essa dissertação em desenvolvimento).

Por tais características e por haver sido desenvolvido com o objetivo de aferir o rendimento dos alunos dos cursos em relação aos conteúdos programáticos, suas habilidades e competências, julgou-se que o Enade 2011 é uma ótima ferramenta para visualizar o aprendizado dos alunos na vida acadêmica. 
Por meio de conversas informais com professores que trabalharam na elaboração da prova do Enade descobriu-se que todos os anos um tema é definido para ser mais intensamente abordado nas provas. Coincidentemente, no ano de 2011 a temática escolhida foi a sustentabilidade, o que contribuiu para que conseguíssemos um resultado mais rico com relação a este tema em nossas análises. No exame aplicado no ano de 2011, 7 questões objetivas abordaram diretamente a temática, representando $25 \%$ da prova específica (7/27), bem como, todas as 3 questões discursivas específicas da prova (3/3).

No ano de 2011 todos os estudantes concluintes dos cursos analisados deveriam ser inscritos pela respectiva IES e realizar o exame, pois neste ano não houve processo de amostragem. A prova presencial foi composta por 10 questões de formação geral (sendo 2 discursivas) e 30 questões de componente específico (sendo 3 discursivas).

Destaca-se que os dados do Enade 2011 contemplam os resultados da prova de mais de nove mil (9.000) alunos de cursos de Arquitetura e Urbanismo do Brasil - já descartadas as provas dos alunos que não entraram na contabilidade do Conceito Enade por alguma inconsistência, problema na prova ou cadastro - de cento e oitenta e uma (181) escolas de Arquitetura e Urbanismo brasileiras que participaram deste evento.

Tal fato permite considerar a prova do Enade 2011 como a fonte de dados de maior abrangência sobre a verificação dos conhecimentos em sustentabilidade, pois o evento tem como meta principal avaliar todos os formandos de todos os cursos de Arquitetura e Urbanismo do Brasil, no ano de sua aplicação.

Destaca-se que o Enade possui um programa bastante amplo e, por isso, propicia diversos produtos, dentre eles: Conceito Enade, Relatório da IES, Relatório-síntese da área, Relatório de curso, variáveis de insumo (infraestrutura, programa, recursos didáticos, perfil do corpo docente), dados para censo, dentre outros. No entanto, esses produtos não foram considerados neste trabalho por terem sido trabalhados com objetivos diversos do mesmo, sendo utilizados apenas os microdados fornecidos pelo Enade, ou seja, as planilhas com os dados coletados pelo exame de forma decomposta, detalhada, separadas por curso e por questão da prova.

Desta forma, foram utilizados os microdados do Enade para o desenvolvimento de uma nova análise do ensino considerando somente as questões de componente específico voltadas aos conhecimentos da sustentabilidade, o que gerou novos resultados $\mathrm{e}$ 
qualificação diversa e independente da encontrada pelo Enade "geral". Esta nova análise, desenvolvida para servir de referência na pesquisa desenvolvida nesta dissertação, foi denominada "Enade-sustentabilidade".

\subsubsection{1 "Enade-sustentabilidade"}

Para que os dados coletados pelo Enade 2011 refletissem, de fato, o desempenho dos alunos nas questões que abordaram a temática da sustentabilidade, foram necessárias algumas adequações e o recálculo das notas, buscando dois objetivos:

1. Obter uma nota que considerasse somente as questões que abordaram os temas englobados pela sustentabilidade;

2. Considerar apenas as notas dos cursos de Arquitetura e Urbanismo que tiveram uma participação representativa de seus alunos no exame.

O primeiro objetivo visa filtrar a prova buscando uma nova avaliação que considere apenas as questões que abordaram a temática da sustentabilidade. Já o segundo objetivo visa retirar da análise aqueles cursos em que um número muito reduzido de alunos realizou a prova, não caracterizando, portanto, uma amostra representativa.

É válido lembrar que intenção deste trabalho não é a de questionar os resultados apresentados pelo Enade, mas de utilizar o amplo banco de dados produzido pelo exame para coletar e tratar os dados necessários para a análise desenvolvida.

Considerando o exposto, o tratamento de dados do Enade 2011 seguiu as seguintes etapas:

\section{a) Seleção das questões da prova de Arquitetura e Urbanismo que abordaram o tema da sustentabilidade:}

Nesta etapa, todas as questões da prova de arquitetura do Enade 2011 foram analisadas buscando identificar quais delas abordaram a sustentabilidade ambiental. A análise foi delimitada pela identificação de itens listados no Quadro 3, referência de sustentabilidade ambiental definida para as análises desenvolvidas nesta dissertação de mestrado.

O resultado desta avaliação apontou que as questões objetivas de número 15, 17, 19, $23,26,32$ e 33 , assim como todas as três questões discursivas específicas da prova (3, 4 e 
5) abordaram claramente pelo menos uma das temáticas da sustentabilidade ambiental elencadas no quadro citado. Contudo, as questões de número 26 e 33 foram anuladas pelo concurso. Logo, restaram as demais questões para análise que estão transcritas junto aos respectivos gabaritos e padrões de respostas, no Anexo 01 desta dissertação.

\section{b) Cálculo da nota "Enade-sustentabilidade"}

Selecionadas as questões que abordavam a temática da sustentabilidade, foi calculada a nota denominada "Enade-sustentabilidade" utilizando a mesma metodologia de cálculo do "Conceito Enade", primeiramente, para a nota de cada aluno e, posteriormente, para a nota de cada escola. Contudo, foram necessárias algumas adaptações.

A metodologia de cálculo do Conceito Enade, que consta no Anexo 02 - Cálculo do Conceito Enade (INEP, 2008), considera, além das questões de conhecimento específico de cada curso, questões de conhecimentos gerais. Porém, as questões de conhecimentos gerais não foram levadas em consideração no cálculo do "Enade-Sustentabilidade", visto que o foco deste trabalho é a avaliação exclusiva do ensino da sustentabilidade nos cursos de arquitetura e não dos demais conhecimentos. Desta forma, a nota final dos alunos e de cada curso, que originalmente considerariam um peso de 0,25 para conhecimentos gerais e 0,75 para conhecimentos específicos, conforme consta na Equação 11 do Anexo 02 (INEP, 2008), passou a considerar um peso igual a 0 (zero) para conhecimentos gerais e 1 (um) para conhecimentos específicos em sustentabilidade na arquitetura.

Outra adequação que se tornou necessária foi com relação ao ajuste nos pesos entre as questões discursivas e objetivas, pois filtrando somente as questões que abordaram a temática da sustentabilidade para este trabalho, as questões discursivas permaneceram em mesmo número em relação à prova geral, mas houve uma redução significativa no número de questões objetivas (de 27 para 5).

No cálculo original, a prova discursiva representaria $15 \%$ da nota final, enquanto as objetivas, $85 \%$. Como a prova geral de arquitetura contou com 3 (três) questões discursivas e 27 (vinte e sete) questões objetivas, já excluídas as questões que foram invalidadas ou desconsideradas no gabarito final, significa dizer que cada questão discursiva representava $5 \%$ da nota final ( $15 \%$ dividido por 3 ), e que cada questão objetiva representava $3,15 \%$ da nota final (85\% dividido por 27). Observa-se que o peso relativo das questões discursivas é maior que os das questões objetivas (uma questão discursiva vale 59\% mais que uma 
objetiva: $\frac{5 \%-3,15 \%}{3,15 \%}=59 \%$ ), e a intenção do ajuste aqui empregado foi justamente manter tal proporção.

Através de uma distribuição ponderada dos pesos para as 3 questões discursivas e para as 5 questões objetivas consideradas na nota do "Enade-Sustentabilidade", chegou-se aos pesos de $48,8 \%$ para a prova discursiva e $51,2 \%$ para a prova objetiva. Nesta proporção, a diferença relativa entre cada questão discursiva e cada questão objetiva continua sendo de $59 \%$, conforme demonstram os dados da Tabela 1 a seguir.

Tabela 1: Ajustes nos pesos entre questões objetivas e subjetivas do Enade para o "Enade-

Sustentabilidade"

\begin{tabular}{|l|c|c|c|c|}
\hline & objetivas & subjetivas & $\begin{array}{c}\text { diferença entre os pesos } \\
\text { das questões subjetivas } \\
\text { e objetivas }\end{array}$ & $\begin{array}{c}\text { diferença relativa entre } \\
\text { os pesos das questões } \\
\text { subjetivas e objetivas }\end{array}$ \\
\hline $\begin{array}{l}\text { Número de questoes } \\
\text { consdieradas na prova do ENADE }\end{array}$ & 27 & 3 & & \\
\hline $\begin{array}{l}\text { Peso das provas no ENADE "geral" } \\
\text { Peso por questão no ENADE } \\
\text { "geral" }\end{array}$ & $85,0 \%$ & $15,0 \%$ & & $59 \%$ \\
\hline $\begin{array}{l}\text { Número de questões } \\
\text { consideradas no ENADE- } \\
\text { SUSTENTABILIDADE }\end{array}$ & 5 & 3 & & \\
\hline $\begin{array}{l}\text { Peso ajustado das provas para o } \\
\text { ENADE-SUSTENTABILIDADE }\end{array}$ & $51,2 \%$ & $48,8 \%$ & & \\
\hline $\begin{array}{l}\text { Peso por questão para o ENADE- } \\
\text { SUSTENTABILIDADE }\end{array}$ & $10,2 \%$ & $16,3 \%$ & 0,0185 & \\
\hline
\end{tabular}

Após este devido ajuste, prosseguiu-se com a aplicação da metodologia de cálculo do Enade, conforme as equações contidas no Anexo 02 desta dissertação, para alcance da nota do "Enade-Sustentabilidade", que consiste resumidamente em:

- Para cada aluno, soma dos acertos de cada uma das cinco questões objetivas, valendo 20 pontos cada, de forma que a nota final da prova objetiva varie entre 0 e 100 ;

- média das avaliações das três questões discursivas, variando de 0 a 100 , para determinação na nota final da prova discursiva; 
- cálculo da nota final "Enade-sustentabilidade" do aluno, considerando os pesos de $51,2 \%$ para a nota da prova objetiva e $48,8 \%$ para a prova discursiva;

- cálculo da média das notas dos alunos de um mesmo curso:

- cálculo da média das notas dos cursos;

- cálculo do desvio padrão entre as notas dos cursos;

- cálculo do afastamento padronizado de cada nota dos cursos, para ajuste da nota na escala de 0 a 5 ;

- cálculo das notas padronizadas do "Enade-sustentabilidade" para cada curso, variando de 0 a 5 ;

- ajuste das notas padronizadas, considerando os respectivos afastamentos, de forma a adequar os valores outliers - valores muito discrepantes dos demais da amostra - para adequação à escala de 0 a 5 ;

- atribuição dos conceitos conforme as notas finais padronizadas de cada curso e a escala adotada pelo Enade (Tabela 2).

Tabela 2: Conceitos adotados pelo Enade conforme as notas finais dos cursos

\begin{tabular}{|c|c|}
\hline Conceito Enade & Notas finais $(N C)$ \\
\hline 1 & 0,0 a 0,94 \\
2 & 0,95 a 1,94 \\
3 & 1,95 a 2,94 \\
4 & 2,95 a 3,94 \\
5 & 3,95 a 5,0 \\
\hline
\end{tabular}

As notas finais de cada escola para o "Enade-Sustentabilidade", encontram-se no Apêndice 01 desta dissertação, juntamente com alguns dos dados que as compõem.

\section{c) Análise da representatividade das avaliações e filtro da amostra}

Conforme informado anteriormente, foi necessário filtrar os resultados da amostra de maneira que fossem selecionados os cursos cuja representatividade dos alunos que fizeram o exame possibilitasse confiabilidade estatística. $\mathrm{O}$ fato se deu pela observância de que 
alguns cursos inscreveram um pequeno número de alunos para realizar o exame. As duas primeiras colocadas no "Enade-Sustentabilidade", por exemplo, contaram com apenas 3 (três) e 5 (cinco) alunos em suas respectivas amostras, evidenciando uma confiabilidade muito baixa da avaliação para que esta possa ser representativa para a escola. Somando-se a isto, há dados do censo da educação superior que indicam que as turmas dos cursos citados seriam formadas por mais de 60 (sessenta) alunos, cada.

Considerando o exposto, foi calculado um ponto de corte para cada escola, denominado “amostra mínima”. A amostra mínima é um número mínimo de alunos para que a nota seja considerada como estatisticamente representativa no "EnadeSustentabilidade", calculada conforme a equação de amostragem em populações finitas a seguir:

Equação 01 - Equação de Amostragem de Populações Finitas (TRIOLA, 1999)

$$
n=\frac{\sigma^{2} \cdot p \cdot q \cdot N}{e^{2} \cdot(N-1)+\sigma^{2} \cdot p \cdot q}
$$

Onde:

- $n=$ Tamanho da amostra.

- $\sigma^{2}=$ Nível de confiança escolhido, expresso em número de desvios-padrão.

- $\quad p=$ Percentagem com a qual o fenômeno se verifica.

- $\mathrm{q}=$ Percentagem complementar $(100-\mathrm{p})$.

- $\quad N=$ Tamanho da população.

- $e^{2}=$ Erro máximo permitido.

Para fins deste trabalho, buscando ser conservador na seleção, ou seja, só desconsiderar da amostra os cursos que apresentem discrepâncias realmente grandes entre o número de alunos ingressantes por ano e o número de alunos que fizeram a prova do Enade, adotou-se um nível de confiança de $80 \%$ (ou 1,282 desvios padrão). Isso significa que estima-se com $80 \%$ de certeza de que o valor da amostra mínima é correto. Para 
estimativas conservadoras, os valores de " $p$ " e " $q$ " são 0,5 e o erro máximo permitido é de $10 \%$.

Já para o valor do tamanho da "população" de cada curso (“ $N$ "), ou seja, o número de alunos nas turmas de arquitetura aptos a realizar o exame do Enade, foi utilizada uma estimativa com base no número de alunos ingressantes no curso de cada IES no ano de 2007. Porém, seria demasiado rígido considerar que todos os alunos que ingressaram no curso estariam aptos a se formarem e realizarem o exame no ano de 2011. Dessa forma, adotou-se como população de cada curso o número de alunos ingressantes no curso em 2007, subtraído de um percentual de evasão ao longo do curso.

Para os valores de evasão, por sua vez, adotou-se dados do estudo "A evasão no ensino superior brasileiro" (Filho; et. al, 2007), que apontam que o índice médio de evasão em cursos públicos é de $12 \%$ e em cursos particulares, de $26 \%$. Os percentuais foram então aplicados e subtraídos ao número de alunos ingressantes nos cursos de arquitetura em 2007, conforme dados do "Censo da Educação Superior-2007” (INEP, 2013). Os resultados, para cada IES, estão presentes na tabela constante no Anexo 02.

A título de exemplo, consideremos dois casos, do primeiro e terceiro cursos colocados no cálculo do "Enade-sustentabilidade": "Universidade Paulista - UNIP de Santana de Parnaíba-SP" e "Universidade Federal do Rio Grande do Norte - UFRN - Natal-RN", respectivamente. A Universidade Paulista - UNIP, de Santana de Parnaíba-SP, seria a primeira colocada no "Enade-sustentabilidade", com nota final padronizada igual à 5, o que significa um conceito também igual a 5. Porém, conforme dados do Censo da Educação Superior-2007 (INEP, 2013), 63 (sessenta e três) alunos ingressaram na instituição no ano de 2007. Considerando uma evasão média de $26 \%$, teríamos em torno de 47 (quarenta e sete) alunos aptos a realizar o exame do Enade em 2011. Ao aplicarmos a Equação 01 exposta anteriormente para cálculo de uma amostra mínima aceitável para representar os resultados do curso da IES, considerando a população " $N$ " igual a 47, chegamos ao valor de $n=22$. Ou seja, no mínimo 22 (vinte e dois) alunos deveriam realizar a prova para que possamos considerar que o resultado do "Enade-sustentabilidade" refletiu o resultado do curso com um nível de confiança de $80 \%$. Observa-se, porém, conforme os dados do Enade, que apenas 3 (três) alunos do curso realizaram o exame, impossibilitando a qualificação dela como um curso que se destaca no âmbito do ensino da sustentabilidade 
no curso de Arquitetura e Urbanismo. Os três alunos que realizaram a prova, porém, foram exemplares na matéria.

A Universidade Federal do Rio Grande do Norte - UFRN, por sua vez, também se posicionando com conceito 5 no "Enade-sustentabilidade", teria 40 (quarenta) alunos ingressando em 2007. Aplicando-se o índice de evasão (12\% para IES públicas), resulta-se em 35 (trinta e cinco) alunos aptos a realizar o exame do Enade. Ao se calcular a mostra mínima com base na Equação 01, sendo " $N$ " igual a 35, temos $n=19$. Logo, seria necessário uma amostra mínima de 19 alunos para que a nota do curso fosse considerada representativa para o curso. Conforme dados do Enade, 22 (vinte e dois) alunos realizaram o exame. Portanto, curso permanece na amostra com destaque entre as demais no ensino da sustentabilidade no curso de Arquitetura e Urbanismo.

O levantamento dos cursos de Arquitetura e Urbanismo brasileiros que apresentaram os maiores conceitos no "Enade-sustentabilidade" será apresentado na Tabela 5, seção 5.1; e os cursos selecionados para análise serão apresentados no capítulo de resultados, Tabela 6, seção 5.1 desta dissertação de mestrado.

\subsection{LEVANTAMENTO E SISTEMATIZAÇÃO DOS DADOS}

Após a seleção dos cinco (5) cursos de Arquitetura e Urbanismo a serem analisados, partiu-se para as etapas de definição dos critérios de análise, levantamento de dados do ensino e sistematização dos dados.

\subsubsection{Critérios de análise}

A partir da revisão bibliográfica desta dissertação foram identificadas as seguintes informações de interesse para a análise do ensino da sustentabilidade nos cursos de Arquitetura e Urbanismo selecionados:

- Quais disciplinas do curso que abordam a sustentabilidade;

- métodos de ensino mais utilizados;

- critérios de avaliação mais utilizados; 
- verificação da integração das disciplinas especializadas com a prática de projeto ou com outras disciplinas;

- classificação do currículo analisado em um dos cinco modelos paradigmáticos identificados pelo EDUCATE;

- carga horária destinada à temática;

- período de inserção da temática no currículo;

- relato das experimentações didáticas

Sobre a definição de sustentabilidade para efeito das análises realizadas nesta dissertação de mestrado, mesmo reconhecendo toda sua amplitude e complexidade conforme destacado na Seção 2.1 da revisão bibliográfica, optou-se por considerar os mesmos conteúdos delimitados pelo grupo EDUCATE em suas análises, conforme apresentado no Quadro 3, Seção 2.1. Desta forma, procurou-se reduzir as possibilidades de conflitos em qualquer comparação que se tornasse interessante entre as novas análises com relação àquelas já desenvolvidas pelo EDUCATE.

\subsubsection{Levantamento de dados}

Após a seleção dos cinco cursos de Arquitetura e Urbanismo a serem analisados, partiu-se para o levantamento de dados do ensino ofertado. Primeiramente, foi levantada a seguinte documentação (ver Figura 10):

- projetos político pedagógicos dos cursos (incluindo currículos)

-planos de ensino (incluindo ementas, objetivos, conteúdos, métodos de ensino e critérios de avaliação).

Esses documentos foram escolhidos porque, oficialmente, eles fazem parte do planejamento do ensino na graduação e devem apresentar o resumo das principais características do ensino ofertado, bem como, grande parte das informações de interesse para a análise do ensino da sustentabilidade nos cursos de Arquitetura e Urbanismo no Brasil. 


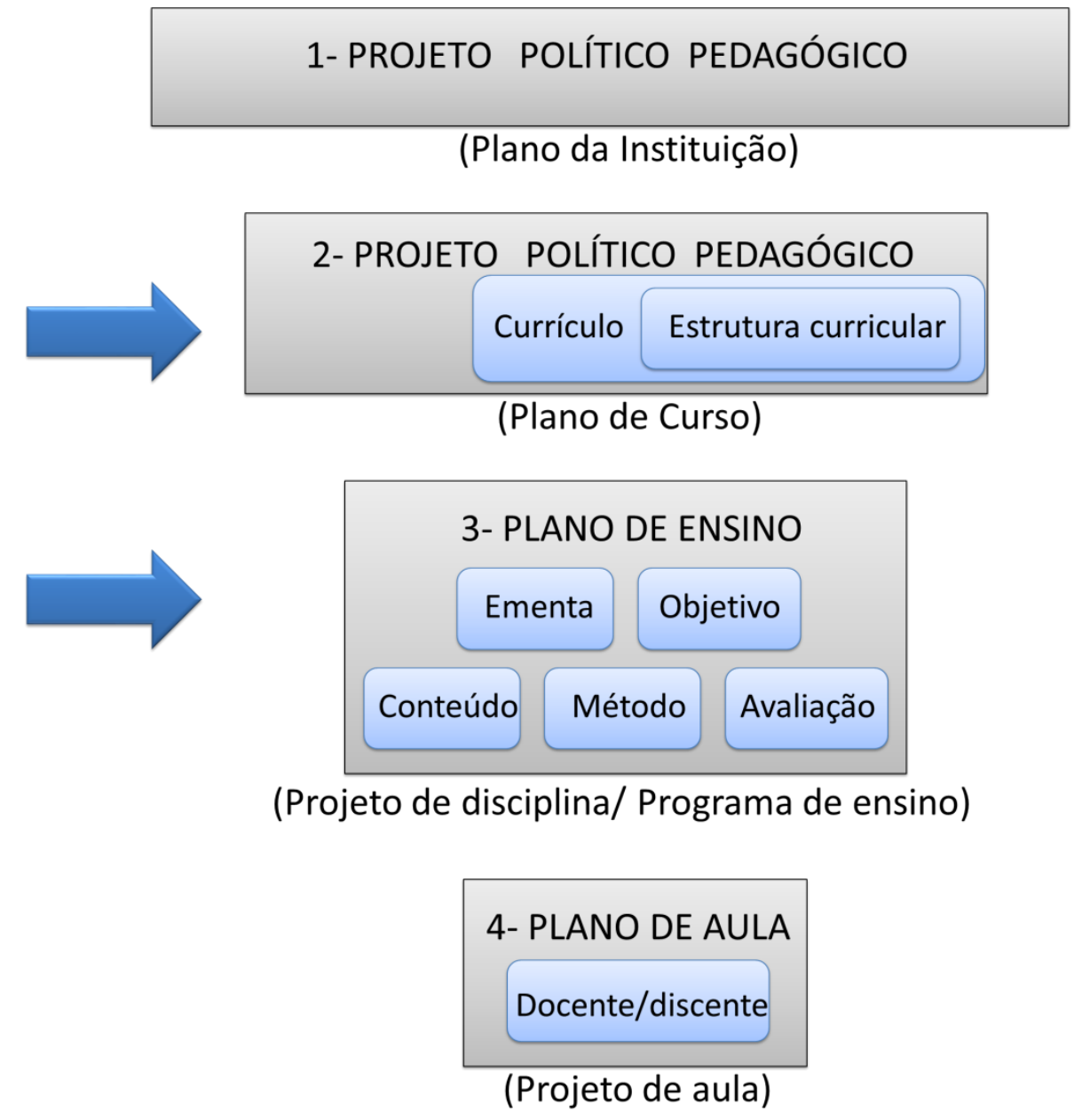

Figura 10: Estrutura do Planejamento do Ensino na Graduação

O projeto político pedagógico de uma instituição/departamento é a reflexão e a expressão contínua das ideias sobre a educação superior, sobre a universidade e sua função social, sobre o curso, sobre o ensino, sobre a pesquisa e sua relação com o ensino, sobre a extensão e sua relação com o currículo e sobre a relação teoria e prática. Ele é a forma de se explicitar os objetivos de um curso e orientar as estratégias a serem utilizadas (Stocco, 2005). De acordo com a Lei de Diretrizes e Bases -LDB, $\mathrm{n}^{\circ}$ 9.394/96, o projeto político pedagógico deve conter:

- perfil do profissional a ser formado;

- objetivos gerais e específicos do curso;

- descrição do currículo pleno oferecido, com ementário das disciplinas/atividades (o currículo deve explicitar a adequação da organização pedagógica ao perfil profissional definido); 
- bibliografia básica;

- número de vagas iniciais e turno de funcionamento;

- relação dos docentes e especificação da composição por níveis ( $n^{\circ}$ e \% de doutores, mestres, etc);

- acervo da biblioteca (livros e periódicos especializados)

- apresentação das instalações, equipamentos, laboratórios (no caso de reconhecimento, pode ser citado apenas as alterações e/ou ampliações feitas nas estruturas).

Já os planos de ensino das disciplinas são um roteiro organizado das unidades didáticas para um bimestre, semestre, ano ou, embora não seja recomendado que se mantenha estanque, até para períodos maiores. Esse plano deve conter: ementa da disciplina, justificativa da disciplina em relação aos objetivos gerais da escola e do curso, objetivos gerais, objetivos específicos, conteúdo, desenvolvimento metodológico (métodos e técnicas pedagógicas específicas da disciplina), recursos tecnológicos, formas de avaliação e referencial teórico (livros, documentos, sites etc).

Por conterem visões amplas, tanto dos cursos como das disciplinas, estes dois documentos foram escolhidos como a primeira fonte das informações necessárias para análise do ensino nos cursos selecionados.

O segundo passo, por meio da análise dos planos de ensino ou ementas da totalidade das disciplinas ofertadas nos cursos selecionados, foi identificar as disciplinas que fizeram referência a algum dos conteúdos abordados pela sustentabilidade (constantes no Quadro 3) e também as que fizeram referência a conteúdos afins. Foram então pré-classificadas estas disciplinas como "disciplinas de interesse".

O terceiro passo foi levantar os contatos de e-mail dos professores das "disciplinas de interesse" e elaborar questionários para coleta de informações via correio eletrônico e complementação das informações disponíveis em documentação. Os questionários foram elaborados a partir das informações de interesse elencados no capítulo 3.

O envio do questionário via correio eletrônico apresenta facilidades como: agilidade na obtenção de dados; alcance de pessoas de diversos lugares sem deslocamento; facilidade de tabular dados; alcance de grupos específicos de forma mais ágil; facilidade para o 
entrevistado responder; maior tempo para o participante responder; possibilidade de colher dados com um maior número de pessoas, dentre outras (CESAR, 2012). Logo, foram definidas quais as questões de maior importância para a análise para que o questionário não se tornasse muito longo e objetivando um maior número de respondentes; e que o questionário apresentasse questões objetivas, tanto quanto possível, para facilitar a sistematização das informações coletadas.

Desta forma, foram selecionadas, dentre as informações de interesse, quais seriam as mais importantes e adequadas a serem obtidas por meio do questionário. As informações escolhidas foram:

1- confirmação da abordagem da sustentabilidade de forma direta/ indireta/ ou nenhuma;

2- integração entre teoria e prática (verificar se disciplinas especializadas tem parte prática, com aplicação dos conteúdos em projeto);

3- relatar as experimentações didáticas (verificação dos métodos de ensino e critérios de avaliação utilizados nas disciplinas).

Logo, o questionário foi elaborado contendo quatro questões objetivas acrescidas de espaços opcionais para uma resposta mais explicativa, se houvesse disponibilidade do professor em complementar a informação solicitada. $\mathrm{O}$ resultado pode ser observado no quadro contido na Figura 11 abaixo:

\begin{tabular}{|l|}
\hline Nome do Professor: \\
\hline Nome da Disciplina: \\
\hline Período/Ano/Fase da Disciplina: \\
\hline \\
\hline $\begin{array}{l}\text { 1- Sobre a abordagem da sustentabilidade no conteúdo programático da disciplina. } \\
\text { Classifique a forma de abordagem desta temática (se houver dúvida, verificar } \\
\text { ANEXO ao final do questionário): }\end{array}$ \\
\hline$\quad$ direta (clara, frequente) \\
\hline indireta (eventualmente, ou associada a outras temáticas muito importantes) \\
\hline
\end{tabular}


nenhuma (muito raramente)

Obs.: Se marcou o último item, seu questionário pode ser finalizado aqui.

2-Indique se os conteúdos da disciplina (incluindo os conteúdos de sustentabilidade) acontecem de forma integrada com projeto, e qual a qualidade da integração:

(Obs.: Responda apenas se a disciplina em análise não é uma disciplina específica de projeto em ateliê)

independente (não existem atividades práticas em ateliê de projetos)

parcialmente integrada (parte das atividades da própria disciplina consiste na prática de projeto)

integrada (grande parte das atividades são realizadas em ateliê de projetos)

integrada com uma disciplina de projeto (existe a parceria com alguma disciplina

de projeto para que os conteúdos específicos da disciplina (incluindo

sustentabilidade) sejam repassados no tempo adequado e correspondente às

demandas da disciplina de ateliê de projetos). Qual?

integrada com outra disciplina que não seja em ateliê de projetos. Qual?

- Se há integração, por favor, explique melhor:

\section{3- Quais os métodos de ensino utilizados na disciplina em questão:}

aulas teóricas

Leituras

Seminários

Debates

Pesquisa

palestras de convidados

Exercícios

visitas de campo / levantamento de campo

laboratório físico

laboratório virtual

estudos de caso

situação- problema

Projeto

apresentação das etapas do projeto para os demais colegas e professores (painel de assessoramento)

outros:

- Se puder ser mais específico:

4- Quais os critérios de avaliação utilizados na disciplina em questão:

prova (oral ou escrita)

Exercícios

trabalho escrito/ relatórios

apresentação de seminário

projeto desenvolvido (técnica / criatividade)

representação/ apresentação do projeto 


\begin{tabular}{|l|l|} 
& Maquete \\
\hline & participação/ evolução do aluno \\
\hline $\begin{array}{l}\text { apresentação das etapas do projeto para os demais colegas e professores (painel de } \\
\text { assessoramento) }\end{array}$ \\
\hline outros: \\
\hline - Se puder ser mais específico: \\
\hline
\end{tabular}

Figura 11: Questionário sobre o ensino da sustentabilidade enviado aos professores das "disciplinas de interesse"

As quatro questões definidas para compor o questionário se justificam pelos seguintes motivos:

Questão 01 - Identificar se a "disciplina de interesse" abordava a temática da sustentabilidade. Se abordasse, como se dava a abordagem em profundidade pelo ponto de vista do próprio professor da disciplina, que possui uma clareza maior do que está sendo ensinado. Tal questão permitiu saber se a disciplina teria sua parcela de contribuição no ensino da sustentabilidade e se deveria ser analisada mais profundamente quanto às suas características.

Questão 02 - Considerando a pesquisa bibliográfica apresentada nesta dissertação e as análises desenvolvidas pelo EDUCATE, verificou-se a importância de identificar a integração dos conteúdos da sustentabilidade com a aplicação prática em projeto, pois constatou-se a sua importância no ensino. Contudo, as disciplinas de projeto que abordaram a sustentabilidade, já propiciam esta integração e foram excluídas desta questão. Somando-se a isso, foi disponibilizado um espaço para tratar de qualquer observação sobre a integração que o professor achasse importante destacar sobre o ensino.

Questão 03 - Identificar os métodos de ensino utilizados pelos cursos, pois este pode ser um diferencial importante na qualidade do ensino ofertado. Logo, a partir dos temas mais recorrentes nos planos de ensino levantados, foram elencados itens que possibilitariam aos professores indicar os métodos de ensino utilizados no curso de forma objetiva. Somando-se a isso, foi disponibilizado um espaço para tratar de qualquer método adicional que não estivesse listado na questão. 
Questão 04 - Identificar os critérios de avaliação utilizados pelos cursos, pois este pode ser um diferencial importante na qualidade do ensino ofertado. Logo, a partir dos temas mais recorrentes nos planos de ensino levantados, foram elencados itens que possibilitariam aos professores indicar os critérios de avalição utilizados no curso de forma objetiva. Somando-se a isso, foi disponibilizado um espaço para tratar de qualquer método adicional que não estivesse listado na questão.

Destaca-se que, juntamente com o questionário, foi enviado em anexo no e-mail o Quadro 3 com a delimitação dos conteúdos abrangidos pela sustentabilidade ambiental para efeitos da análise realizada. Este quadro poderia ser acessado pelos entrevistados que tivessem dúvida quanto à inclusão no tema de alguma temática específica.

Por fim, de posse dos dados coletados, partiu-se para a sistematização dos mesmos.

\subsubsection{Sistematização dos dados}

Em resumo, o levantamento de dados dos cursos selecionados partiu de informações documentais. Na sequência, houve uma pré-seleção das disciplinas de interesse e inserção das informações coletadas em planilhas. Depois foram enviados os questionários para os professores das disciplinas de interesse e, então, complementadas as informações já coletadas.

Logo, nos casos das disciplinas em que não houveram respostas aos questionários enviados, as informações sobre as mesmas foram retiradas da documentação levantada. Já as disciplinas que não houveram respostas aos questionários e que não foram encontradas informações em documentação, foram consideradas como se não abordassem a sustentabilidade. Ao final, chegou-se ao levantamento apresentado nesta dissertação de mestrado.

Os dados levantados foram organizados em planilhas resumo com as seguintes informações:

- nome da disciplina, código;

- créditos, carga horária;

- período em que é ofertada;

- se obrigatória ou eletiva; 
- se disciplina especializada / de projeto em ateliê / ou outras;

- módulo-tema (classificação das disciplinas por grupo temático -ver Apêndice 02);

- se a abordagem da sustentabilidade se dá de forma direta/ indireta/ ou nenhuma;

- se a disciplina é integrada com alguma disciplina de projeto;

- se a disciplina transmite os conteúdos de forma integrada/ parcialmente integrada/ ou nenhuma integração com a prática projetual na própria disciplina;

- resumo do conteúdo;

- métodos de ensino (sistematização das informações em itens pré-estabelecidos e listados no questionário);

- critérios de avaliação (sistematização das informações em itens préestabelecidos e listados no questionário).

Logo, a partir das planilhas organizadas com as informações coletadas sobre cada curso, foram desenvolvidos, como primeiro produto de análise, diagramas sobre a integração entre disciplinas que abordam a sustentabilidade com a prática projetual para cada currículo. Este diagrama, baseado no modelo de diagrama desenvolvido pelo grupo EDUCATE (apresentado na Figura 6), foi uma forma compreensível e didática encontrada para representar a integração dos conteúdos teóricos da sustentabilidade com a prática projetual na análise das "disciplinas de interesse".

Para a sistematização do diagrama, primeiramente, as disciplinas analisadas foram classificadas por grupo temático denominado "módulo-tema", conforme Apêndice 02. Procedeu-se a esta classificação para facilitar a visualização do tema principal tratado em cada disciplina, já que a denominação das disciplinas varia de curso para curso, e no intuito de auxiliar a identificação da área disciplinar a que cada disciplina pertence. Logo, no diagrama não consta o nome da disciplina, e sim, o nome do módulo-tema correspondente. Desta forma, destaca-se que diferentes disciplinas, de um mesmo período, podem ser agrupadas em um mesmo módulo-tema, se tratarem do mesmo tema.

Na sequência, as disciplinas foram classificadas conforme três áreas disciplinares: 
1. Disciplinas especializadas - disciplinas que abordam a sustentabilidade (representadas pela cor azul);

2. Disciplinas de projetos em ateliê - incluem disciplinas de projeto arquitetônico, urbanístico e de planejamento urbano (representadas pela cor rosa);

3. Outras disciplinas - disciplinas que abordam outros conteúdos (representadas pela cor cinza).

Foram então desenhados os diagramas de cursos brasileiros contendo todas as disciplinas obrigatórias e também de disciplinas eletivas que abordam a sustentabilidade. Ficou definida a apresentação no diagrama apenas as disciplinas eletivas que correspondem ao mínimo que deve ser cursado para a conclusão do curso ou do semestre, conforme a regra de cada curso analisado (quando não há indicação de qual semestre devem ser cursadas as eletivas, estas foram distribuídas de maneira uniforme nos últimos períodos). Para maior clareza, especificou-se o mínimo de eletivas por escrito no rodapé de cada período do diagrama. A representação do tipo de disciplina (se obrigatória ou eletiva) se deu pela definição da linha que contorna cada célula.

Os diagramas desenvolvidos para esta dissertação de mestrado, contudo, incluíram identificação do tipo de abordagem da sustentabilidade (se abordagem nas disciplinas acontece de forma direta ou indireta), o que representou a primeira evolução à análise desenvolvida pelo EDUCATE. A representação do nível de abordagem (se direta ou indireta) se deu por meio da distinção de cores.

Logo, a representação das informações coletadas pode ser melhor compreendida pela descrição abaixo e também pela Figura 12:

- Azul escuro = Especializada com abordagem direta da sustentabilidade

- Azul claro = Especializada com abordagem indireta da sustentabilidade

- Rosa escuro $=$ Disciplina de projeto em ateliê com abordagem direta da sustentabilidade

- Rosa claro = Disciplina de projeto em ateliê com abordagem indireta ou sem abordagem da sustentabilidade 
- $\quad$ Cinza $=$ outras

- Linha contínua: Disciplina obrigatória

- Linha picotada: Disciplina eletiva

\begin{tabular}{|c|c|c|}
\hline & Obrigatórias & Eletivas/Optativas \\
\hline $\begin{array}{l}\text { Módulo Especializado com abordagem } \\
\text { direta de sustentabilidade }\end{array}$ & $\mathrm{x}$ & $\mathrm{x}$ \\
\hline $\begin{array}{l}\text { Módulo Especializado com abordagem } \\
\text { indireta de sustentabilidade }\end{array}$ & $\mathrm{x}$ & $\mathrm{x}$ \\
\hline $\begin{array}{l}\text { Módulo de projeto/ateliê com } \\
\text { abordagem direta de sustentabilidade }\end{array}$ & $\mathrm{x}$ & $x$ \\
\hline $\begin{array}{l}\text { Módulo de projeto/ateliê com } \\
\text { abordagem indireta ou sem abordagem } \\
\text { de sustentabilidade }\end{array}$ & $\mathbf{x}$ & $\mathrm{x}$ \\
\hline Outros Módulos/Disciplinas & $\mathbf{x}$ & $x$ \\
\hline
\end{tabular}

Figura 12: Legenda do diagrama de análise da integração das disciplinas nos currículos

Além das definições já citadas, foram acrescentados aos diagramas desenvolvidos nesta dissertação a carga horária correspondente a cada disciplina, além do número de créditos que já vinha sendo apresentado. Isto porque, no caso das análises comparativas entendeu-se que a comparação de carga horária seria mais exata devido à grande variação que existe no cálculo dos créditos em cada curso.

Definidas a forma de representação das informações acima, passou-se à representação da integração de cada disciplina especializada com atividades práticas de projeto. Por meio da Questão 02 do questionário e da documentação levantada foi possível identificar variação na forma de integração entre conteúdos teóricos da sustentabilidade e atividades práticas em projeto. Logo, a representação da integração no diagrama foi baseada inicialmente no modelo de diagrama exemplificado na Figura 6, Seção 3.5, conforme descrição abaixo:

1. Sem integração - a célula que representa a disciplina especializada não toca a área de projeto. 
2. Parcialmente integrada - a célula da disciplina especializada perpassa a área de projeto.

3. Integrada - a célula da disciplina especializada está contida na área de projeto.

Como uma segunda evolução à análise do EDUCATE, decidiu-se analisar todas as disciplinas que abordassem a temática da sustentabilidade no currículo, incluindo disciplinas de projeto. Tal análise foi desenvolvida devido ao entendimento, apresentado na revisão bibliográfica, de que a abordagem da sustentabilidade nas demais disciplinas, além das especializadas e principalmente nas disciplinas de projeto, contribui diretamente para o melhor aprendizado da temática pelos alunos. Desta forma, no caso das disciplinas de projeto, não coube análise de integração, pois constituem-se basicamente de atividades de projeto. Porém, foram representados na cor rosa escuro as disciplinas que indicaram abordagem direta sobre sustentabilidade e as demais foram representadas na cor rosa claro.

Acompanhando a metodologia desenvolvida pelo EDUCATE, após a elaboração dos diagramas, passou-se a um segundo produto de análise, o gráfico da carga horária das disciplinas obrigatórias classificadas por tipo, por período. Neste produto, as disciplinas mantiveram a mesma classificação por área disciplinar definida para o diagrama e foi reapresentada a carga horária das disciplinas obrigatórias em gráficos tipo barra para cada período letivo do curso.

Por fim, esclarecemos que as duas modificações realizadas no diagrama e gráfico citados podem ser classificadas como informações adicionais aos modelos desenvolvidos pelo EDUCATE. Desta forma, as novas análises não divergem das análises já desenvolvidas pelo grupo EDUCATE, se desejarmos obter os dados correspondentes às análises originais, é necessário apenas ignorar alguns tons de cores nos diagramas e gráficos. Tal alinhamento foi importante para poder contribuir com novas análises para o banco de dados que já vinha sendo desenvolvido pelo grupo.

Posteriormente, foram comparados diferentes aspectos dos currículos analisados entre os cursos, com o objetivo de evidenciar as principais diferenças e características.

Por fim, as análises realizadas para cada curso são apresentadas no capítulo seguinte. 


\section{RESULTADOS E DISCUSSÕES}

Este capítulo apresenta o cruzamento de dados para a seleção dos cursos que mais se destacaram no ensino da sustentabilidade considerando os eventos analisados. $\mathrm{Na}$ sequência, são apresentados as análises desenvolvidas a partir dos projetos político pedagógicos, currículos e planos de ensino de cada um dos cursos selecionados e comparativamente entre os mesmos. Por fim, discute sobre as principais características identificadas nos currículos analisados e apresenta subsídios para a abordagem da sustentabilidade no ensino da graduação em Arquitetura e Urbanismo.

\subsection{SELEÇÃO DOS CURSOS}

Com o objetivo de delimitar uma amostra com os cursos que se mais se destacaram no ensino da sustentabilidade, para fim do desenvolvimento das análises propostas nesta dissertação de mestrado, levantaram-se, primeiramente, os cursos de Arquitetura e Urbanismo brasileiros com maior número de trabalhos selecionados (dentre trabalhos premiados, menções honrosas e trabalhos selecionados para a mostra itinerante) nas edições da Bienal Miguel Aroztegui, e da Bienal de Sustentabilidade José Lutzenberger.

O resultado da Bienal Miguel Aroztegui pode ser observado na Tabela 3 a seguir, onde apresentam-se os cursos relacionando-os ao número de trabalhos selecionados nas 7 edições da bienal, em ordem decrescente, e destacando as que se apresentaram acima da média das demais (acima de 3 prêmios):

Tabela 3: Cursos que se destacaram na Bienal Miguel Aroztegui

\begin{tabular}{|l|r|r|}
\hline \multicolumn{3}{|c|}{ BIENAL MIGUEL AROZTEGUI (1999-2011) - 7 edições } \\
\hline Cursos brasileiros de Arquitetura e Urbanismo & Número de prêmios & \multicolumn{1}{|c|}{ Edição da bienal } \\
\hline USP & 7 & $1999,2005,2007,2009$ \\
\hline UFSC & 5 & $2001,2003,2007,2011$ \\
\hline UFRN & 4 & 2009,2011 \\
\hline UFU & 4 & todos 2009 \\
\hline UnB & 4 & $2005,2007,2009$ \\
\hline UFBA & 4 & $2001,2005,2009$ \\
\hline UFV & 3 & 2001,2011 \\
\hline UFC & 3 & todos 1999 \\
\hline UFRJ & 2 & 2001,2011 \\
\hline UEP, UEL, UFF, Unifor, UNIVALI & 1 & 2011 \\
\hline UFAL, UFPE, UFPR, UFPI & 1 & $2007,2007,2007,2005$ \\
\hline UNESP, UFRGS & 1 & 1999 \\
\hline TOTAL & $\mathbf{4 7}$ & \\
\hline
\end{tabular}


O resultado da Bienal de Sustentabilidade José Lutzenberger pode ser observado na Tabela 4 a seguir, onde apresentam-se os cursos relacionando-os ao número de trabalhos selecionados nas 3 edições da bienal, em ordem decrescente, e destacando as que se apresentaram acima da média das demais (acima de 1 prêmio):

Tabela 4: Cursos que se destacaram na Bienal José Lutzenberger

\begin{tabular}{|l|r|r|}
\hline \multicolumn{3}{|c|}{ BIENAL JOSÉ LUTZENBERGER (2007-2011) - 3 edições } \\
\hline $\begin{array}{c}\text { Cursos brasileiros de } \\
\text { Arquitetura e Urbanismo }\end{array}$ & $\begin{array}{c}\text { Número de } \\
\text { prêmios }\end{array}$ & \multicolumn{1}{c|}{ ediçao da bienal } \\
\hline UCS & 3 & 2007,2009 \\
\hline UFRGS & 2 & 2009,2011 \\
\hline UFJF & 2 & 2011 \\
\hline UPF & 1 & 2011 \\
\hline Inst. Metod. Izabela Hendrix & 1 & 2009 \\
\hline UCPE, UEL & 1 & 2007 \\
\hline TOTAL & 11 & \\
\hline
\end{tabular}

$\mathrm{Na}$ Tabela 5 a seguir, estão elencados os cursos que se destacaram no "Enadesustentabilidade" com conceito 5 (cinco), juntamente com a posição final no ranking, demonstrando os cursos que foram excluídos no filtro de amostragem mínima, conforme previamente detalhado na seção 4.1.3.1 desta dissertação de mestrado. Os resultados apresentados dos demais cursos na análise denominada "Enade-sustentabilidade" encontram-se no Apêndice 01.

Tabela 5: Cursos que se destacaram no "Enade-sustentabilidade"

\begin{tabular}{|c|c|c|c|}
\hline Instituição de ensino & $\begin{array}{c}\text { Nota final do } \\
\text { ENADE- } \\
\text { SUSTENTA- } \\
\text { BILIDADE (0-5) }\end{array}$ & $\begin{array}{l}\text { Conceito } \\
\text { ENADE- } \\
\text { SUSTENTA- } \\
\text { BILIDADE }\end{array}$ & $\begin{array}{c}\text { Posição } \\
\text { final }\end{array}$ \\
\hline 322_ UNIVERSIDADE PAULISTA_SANTANA DE PARNAÍBA & 5,00 & 5 & Excluída \\
\hline 322_UNIVERSIDADE PAULISTA_SOROCABA & 4,90 & 5 & Excluída \\
\hline 570_ UNIVERSIDADE FEDERAL DO RIO GRANDE DO NORTE_NATAL & 4,69 & 5 & 1 \\
\hline 1351_INSTITUTO SUPERIOR TUPY - IST_JOINVILLE & 4,64 & 5 & 2 \\
\hline 581_ UNIVERSIDADE FEDERAL DO RIO GRANDE DO SUL_PORTO ALEGRE & 4,57 & 5 & 3 \\
\hline 322_UNIVERSIDADE PAULISTA_BRASÍLIA & 4,55 & 5 & Excluída \\
\hline 56_UNIVERSIDADE ESTADUAL PAULISTA JÚLIO DE MESQUITA FILHO_BAURU & 4,40 & 5 & 4 \\
\hline 583_UNIVERSIDADE FEDERAL DO CEARÁ_FORTALEZA & 4,34 & 5 & 5 \\
\hline 1120_INSTITUTO FEDERAL DE EDUCAÇÃO, CIÊNCIA E TECNOLOGIA FLUMINENS & 4,15 & 5 & 6 \\
\hline 1041_CENTRO UNIVERSITÁRIO UNIVATES_LAJEADO & 4,04 & 5 & 7 \\
\hline 673_CENTRO UNIVERSITÁRIO DA GRANDE DOURADOS_DOURADOS & 4,00 & 5 & Excluída \\
\hline 449_UNIVERSIDADE LUTERANA DO BRASIL_TORRES & 3,99 & 5 & Excluída \\
\hline 322_UNIVERSIDADE PAULISTA_SÃO PAULO & 3,99 & 5 & Excluída \\
\hline 17_UNIVERSIDADE FEDERAL DE UBERLÂNDIA_UBERLÂNDIA & 3,98 & 5 & 8 \\
\hline 9_UNIVERSIDADE ESTADUAL DE LONDRINA_LONDRINA & 3,96 & 5 & 9 \\
\hline
\end{tabular}


Desta forma, considerando os três eventos anteriormente detalhados, foram selecionados para análise na presente dissertação os cursos de Arquitetura e Urbanismo que se destacaram em pelo menos dois dos três eventos, concomitantemente, visando reafirmar o destaque destes cursos no ensino da sustentabilidade em mais de um evento.

Logo, na Tabela 6 estão listados os cursos em ordem alfabética e, destacados em azul, os cursos selecionados.

Tabela 6: Cruzamento de dados para seleção dos cursos a serem analisados.

\begin{tabular}{|c|c|c|c|}
\hline Cursos brasileiros de arquitetura e urbanismo (ordem alfabética) & \begin{tabular}{|c} 
ENADE- \\
SUSTENTABILIDA \\
DE 2011
\end{tabular} & $\begin{array}{c}\text { BIENAL JOSÉ } \\
\text { LUTZENBERGE } \\
\text { R (2007-2011) }\end{array}$ & $\begin{array}{c}\text { BIENAL MIGUEL } \\
\text { AROZTEGUI } \\
\text { (1999-2011) }\end{array}$ \\
\hline CENTRO UNIVERSITÁRIO UNIVATES - UNIVATES & $\mathbf{X}$ & & \\
\hline INSTITUTO FEDERAL DE EDUCAÇÃO, CIÊNCIA E TECNOLOGIA FLUMINENSE - IFF & $\mathbf{X}$ & & \\
\hline INSTITUTO SUPERIOR TUPY - IST & $\mathbf{X}$ & & \\
\hline UNIVERSIDADE DE BRASÍLIA & & & $\mathbf{X}$ \\
\hline UNIVERSIDADE DE CAXIAS DO SUL - UCS & & $\mathbf{X}$ & \\
\hline UNIVERSIDADE DE SÃO PAULO - USP & & & $\mathbf{X}$ \\
\hline UNIVERSIDADE ESTADUAL DE LONDRINA - UEL & $\mathbf{X}$ & & \\
\hline UNIVERSIDADE ESTADUAL PAULISTA JÚLIO DE MESQUITA FILHO - UNESP & $\mathbf{X}$ & & \\
\hline UNIVERSIDADE FEDERAL DA BAHIA & & & $\mathbf{X}$ \\
\hline UNIVERSIDADE FEDERAL DE JUIZ DE FORA - UFJF & & $\mathbf{X}$ & \\
\hline UNIVERSIDADE FEDERAL DE SANTA CATARINA - UFSC & & & $\mathbf{X}$ \\
\hline UNIVERSIDADE FEDERAL DE UBERLÂNDIA - UFU & $\mathbf{X}$ & & $\mathbf{X}$ \\
\hline UNIVERSIDADE FEDERAL DO CEARÁ - UFC & $\mathbf{X}$ & & \\
\hline UNIVERSIDADE FEDERAL DO RIO GRANDE DO NORTE - UFRN & $\mathbf{X}$ & & $\mathbf{X}$ \\
\hline UNIVERSIDADE FEDERAL DO RIO GRANDE DO SUL - UFRGS & $\mathbf{X}$ & $\mathbf{X}$ & \\
\hline
\end{tabular}

O levantamento realizado e o cruzamento de dados identificaram como cursos que se destacaram no ensino da sustentabilidade os cursos: Universidade Federal de Uberlândia (UFU); Universidade Federal do Rio Grande do Norte (UFRN); e Universidade Federal do Rio Grande do Sul (UFRGS).

Por fim, buscando agregar um número maior de cursos na análise, dentro da capacidade de desenvolvimento do presente trabalho, foram selecionados, adicionalmente, os cursos de Arquitetura e Urbanismo: da USP, pelo fato da pré-existência de alguns dados sobre o mesmo considerando que o curso já havia sido analisado pelo EDUCATE cuja metodologia serve de base para análise na presente dissertação; e da UnB, pois a presente dissertação de mestrado está sendo desenvolvida no âmbito do Programa de Pós Graduação da FAU/UnB e existe o interesse na análise do presente ensino, o que poderá auxiliar em propostas futuras para a melhoria do currículo vigente. 


\subsection{RESULTADOS}

Foram analisados quatro cursos de Arquitetura e Urbanismo, são eles: UFRN, UFRGS, USP e UnB. O curso da UFU não pode ser analisado por motivos expostos no Capítulo 6.

A princípio, relembra-se, para melhor compreensão da análise, que os cursos da UFRN e UFRGS apresentaram os melhores resultados nos eventos analisados, logo, acredita-se que tenham conseguido ofertar um bom ensino com relação à sustentabilidade. O curso da USP, por sua vez, é considerado uma referência nacional e já foi, anteriormente, analisado pelo EDUCATE. Já o curso da UnB foi escolhido por ser da mesma universidade para a qual esta dissertação foi desenvolvida e, desta forma, identificamos que a análise deste ensino poderia contribuir numa futura revisão do ensino da temática neste curso, além da facilidade de acesso aos dados. Feitas estas considerações, passa-se às análises desenvolvidas.

Para as análises realizadas definiu-se que seria interessante responder, sobre os cursos analisados, às mesmas 10 informações que foram respondidas em cada analise realizada pelo grupo EDUCATE, conforme listado na seção 3.5 desta dissertação de mestrado. Desta forma, entende-se que estas análises podem ser complementares ao trabalho do EDUCATE.

Logo, apresentam-se a seguir as informações coletadas e análises desenvolvidas sobre cursos brasileiros organizadas de forma a atender às mesmas 10 levantadas pelo EDUCATE em suas análises. Primeiramente, serão apresentadas as informações que de quatro itens que são comuns aos cursos analisados e, posteriormente, serão apresentadas as informações referentes aos demais itens, por serem diferenciadas em cada curso.

\section{- Nome, duração e título emitido pelo curso}

- Curso de Arquitetura e Urbanismo

- Duração: 5 anos (10 semestres)

- Titulação: Arquiteto e Urbanista (Bacharel) 
- Órgão responsável pelo reconhecimento do curso e por regulamentar a atuação profissional

- Reconhecimento: Ministério da Educação -MEC.

- Regulamentação profissional: Conselho de Arquitetura e Urbanismo (CAU/BR)

- Resultados esperados (descrever a conscientização, conhecimento e habilidades que são esperadas dos estudantes após a conclusão bem sucedida do curso de graduação)

Segundo o MEC (2010) o curso de Arquitetura e Urbanismo deve assegurar a formação de profissionais generalistas, capazes de compreender e traduzir as necessidades de indivíduos, grupos sociais e comunidade, com relação à concepção, à organização e à construção do espaço interior e exterior, abrangendo o urbanismo, a edificação, o paisagismo, bem como a conservação e a valorização do patrimônio construído, a proteção do equilíbrio do ambiente natural e a utilização racional dos recursos disponíveis.

- Resumo dos critérios para a concessão de licença para atuação profissional (descrever como a avaliação dos currículos está relacionada com os requisitos para regulamentação profissional no país de origem)

A licença para atuação profissional é concedida por meio de cadastro junto ao Conselho de Arquitetura e Urbanismo do Brasil (CAU/BR), sendo que este órgão concede licença ao graduado em curso reconhecido pelo MEC. O MEC, por sua vez, procura verificar se o currículo atende às diretrizes curriculares vigentes para reconhecimento do curso.

\subsubsection{Curso de Arquitetura e Urbanismo da UFRN}

5.2.1.1 Objetivos educacionais (destacar os objetivos do curso de graduação de acordo com a estruturação dos objetivos educacionais e profissionais do curso em dada instituição)

Segundo o projeto político pedagógico da Faculdade de Arquitetura e Urbanismo da UFRN (FAU/UFRN, 2005) o curso tem como objetivos específicos habilitar os estudantes a contribuir para a melhoria da qualidade de vida nos assentamentos humanos; manter o equilíbrio ecológico e desenvolvimento sustentável do ambiente natural e construído; 
promover a valorização da arquitetura e do urbanismo como patrimônio e responsabilidade de todos; usar os recursos tecnológicos de modo responsável e coerente com as necessidades sociais, culturais, ambientais e estéticas das comunidades.

\subsubsection{Breve descrição do curso (enfatizar a organização do curso, os objetivos} pedagógicos a serem alcançados e as diferentes opções disponíveis aos alunos)

De acordo com o projeto político pedagógico da FAU/UFRN (2005), o curso de graduação da FAU-UFRN é estruturado por cinco as áreas de estudo:

A Área de Representação e Linguagem tem como objetivo estimular a criatividade do aluno e desenvolver uma linguagem adequada, dando subsídio para as demais áreas, de acordo com as suas especificidades.

A Área de Projeto contribui para a formação de um profissional crítico, capaz de interferir no ambiente construído através de soluções criativas, social e ambientalmente adequadas ao contexto no qual estiverem inseridas e que demonstrem domínio de métodos e técnicas de projetação, bem como a integração de saberes de outras áreas.

A Área de Estudos Urbanos e Regionais atua no espaço físico-territorial e transmite ao estudante noções básicas da relação entre o território e o espaço social, buscando contribuir para a sua formação crítico-analítica. Envolve desde noções básicas do desenho das pequenas aglomerações urbanas e rurais até a problemática da degradação do meio natural e do ambiente construído, assim como os grandes desafios da sociedade pós-moderna.

A Área de História e Teoria da Arquitetura e do Urbanismo busca apreender os conceitos que nortearam a concepção arquitetônica e urbanística nos diversos períodos da história e sua produção, relacionando os condicionantes técnicos, ambientais, sociais e econômicos.

A Área de Tecnologia subsidia, de forma gradual e integrada, as demais áreas do curso, através da instrumentalização dos alunos mediante conceitos e aplicação de recursos tecnológicos, visando o equilíbrio entre o projeto e a execução. Ela compreende disciplinas como Estrutura, Instalações, Conforto Ambiental e Topografia.

Segundo Araújo et al (1999) no período de 1987 a 1989, foram identificados na FAU/UFRN problemas como: grandes índices de reprovação em disciplinas das áreas de 
física e matemática e também relativos à desarticulação entre as áreas de conhecimento (comuns a outros cursos de Arquitetura e Urbanismo do país). Logo, verificou-se a necessidade de modificação profunda em nível curricular e se optou pela integração vertical e horizontal das disciplinas.

De acordo com o projeto político pedagógico da FAU/UFRN (2005), o currículo da UFRN é diferenciado da maioria dos currículos dos cursos de Arquitetura e Urbanismo no Brasil. Os trabalhos integrados se tornam possíveis pela organização dos conteúdos com enfoques definidos, que permitem estabelecer uma série de princípios e tópicos de estudos em concordância.

Logo, considerando a integração horizontal, a cada semestre, procura-se integrar as diversas disciplinas e atividades complementares (quando pertinentes) segundo um enfoque temático que norteia o aprendizado. Os enfoques temáticos foram previamente definidos da seguinte forma:

- primeiro semestre: forma

- segundo semestre: forma, função e sociedade;

- terceiro: projeto e construção do (objeto a definir);

- quarto: o homem e a natureza;

- quinto: o (objeto a definir) e a cidade;

- sexto: o (objeto a definir);

- sétimo: o patrimônio;

- oitavo: complexidade;

- nono: demandas sociais, e

- décimo semestre: trabalho final de graduação com tema livre.

Considerando a integração vertical, os conteúdos dos diversos períodos obedecem a uma sequência lógica e complementar, intensificando sua complexidade a cada semestre. Para tanto, o estudante deve sintetizar o conhecimento acumulado a cada momento do curso.

A estrutura curricular dá ênfase na relação de co e pré-requisitos entre as diferentes disciplinas que compõem a estrutura curricular, (aspecto essencial para o bom desempenho do princípio da integração, tanto do período como do curso como um todo); 
Destaca-se, contudo, que uma característica importante deste currículo é a falta de flexibilidade, pois os alunos devem cursar as disciplinas que trabalham conteúdos comuns de forma simultânea e, caso haja uma reprovação, o aluno ainda pode ser impossibilitado de avançar o semestre, devido ao grande número de pré-requisitos vinculados.

\subsubsection{Estrutura curricular do curso}

De acordo com o projeto político pedagógico de FAU/UFRN (2005), o currículo A-5 (vigente no período da análise) possui carga horária mínima para a conclusão do curso de 4.050 horas-aula, sendo 300 h.a. (7,5\%) provenientes das disciplinas eletivas, 600 h.a. de atividades complementares (15\%- inclui TFG) e as demais 3150 h.a. (77,7\%) de disciplinas obrigatórias (ver Tabela 7).

Tabela 7: Carga horária mínima exigida no curso da UFRN

\begin{tabular}{|l|r|}
\hline & Carga horária \\
\hline Obrigatórias & 3150 \\
\hline Eletivas & 300 \\
\hline $\begin{array}{l}\text { Atividades complementares (inclui } \\
\text { o TFG) }\end{array}$ & 600 \\
\hline Total Mínimo & $\mathbf{4 0 5 0}$ \\
\hline
\end{tabular}

A estrutura curricular do curso de Arquitetura e Urbanismo da FAU-UFRN está no Anexo 03 desta dissertação de mestrado.

5.2.1.4 Sustentabilidade ambiental na estrutura curricular (ilustrar em detalhes as disciplinas que incidem sobre temas de sustentabilidade ambiental (listados no Quadro 3), em cada ano de evolução do curso de graduação, incluindo a descrição do conteúdo, método de ensino e critérios de avaliação

A Tabela com os detalhes da abordagem da sustentabilidade ambiental no currículo da UFRN consta no Apêndice 03 desta dissertação.

5.2.1.5 Integração da temática da sustentabilidade com o ateliê de projetos (visualizar em um gráfico simplificado a estrutura a do curso (disciplinas e créditos), indicando o nível de integração dos conteúdos especializados ensinados com aplicações em ateliê de projetos, baseando-se no modelo de diagrama desenvolvido pelo EDUCATE 


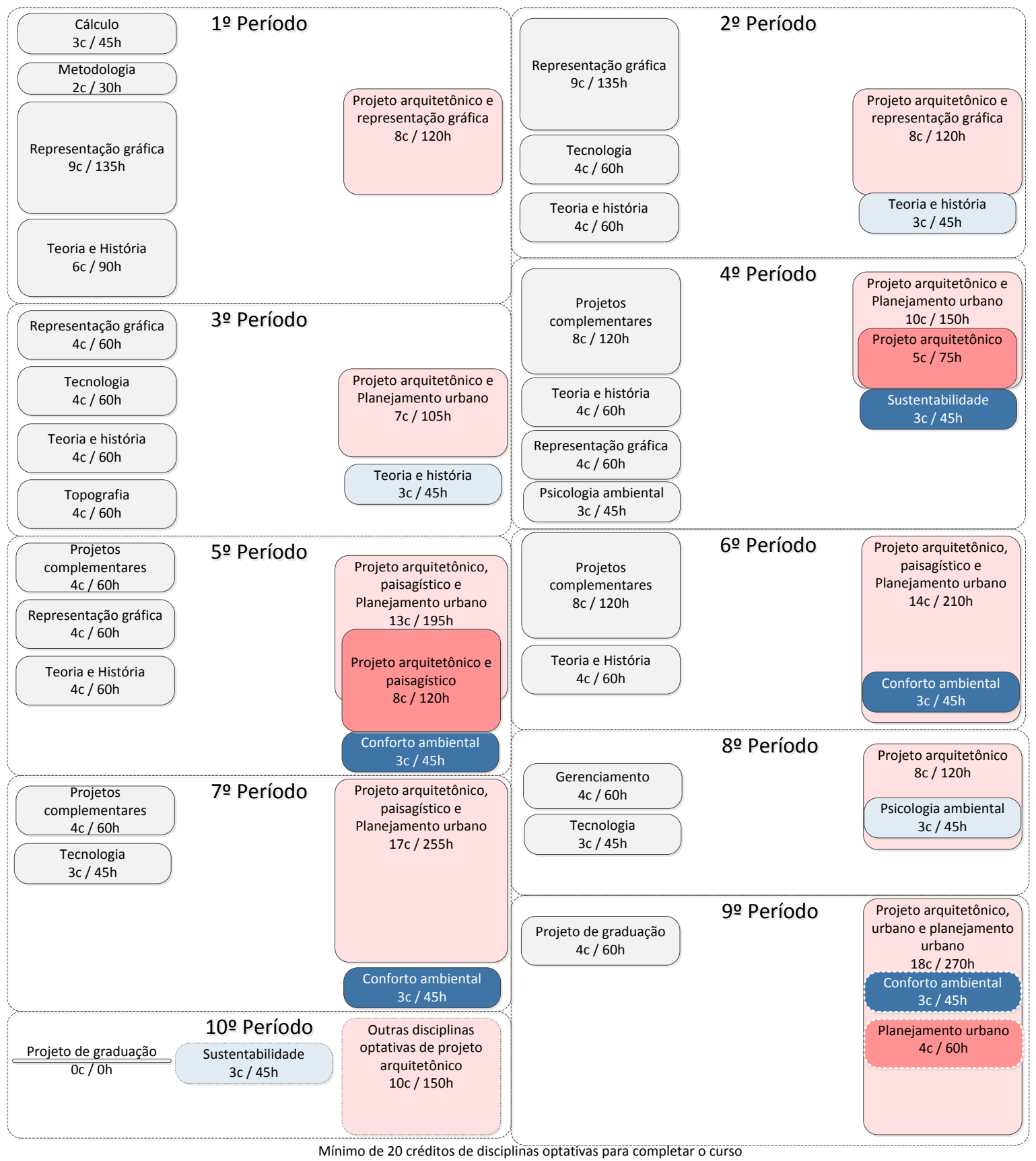

\begin{tabular}{|l|c|c|}
\hline \multicolumn{3}{|c|}{ Legenda } \\
\hline $\begin{array}{l}\text { Módulo Especializado com abordagem } \\
\text { direta de sustentabilidade }\end{array}$ & Obrigatórias & Eletivas/Optativas \\
\hline $\begin{array}{l}\text { Módulo Especializado com abordagem } \\
\text { indireta de sustentabilidade }\end{array}$ & $\mathrm{x}$ & $\mathrm{x}$ \\
\hline $\begin{array}{l}\text { Módulo de projeto/ateliê com } \\
\text { abordagem direta de sustentabilidade }\end{array}$ & $\mathrm{x}$ & $\mathrm{x}$ \\
\hline $\begin{array}{l}\text { Módulo de projeto/ateliê com } \\
\text { abordagem indireta ou sem abordagem } \\
\text { de sustentabilidade }\end{array}$ & $\mathrm{x}$ & $\mathrm{x}$ \\
\hline Outros Módulos/Disciplinas & $\mathrm{x}$ & $\mathrm{x}$ \\
\hline
\end{tabular}

Figura 13: Diagrama da integração entre as disciplinas especializadas e a prática de projeto no currículo do curso da UFRN 
Observa-se no diagrama acima que as disciplinas especializadas em sustentabilidade estão, quase na sua totalidade, integradas às atividades práticas de projeto em ateliê, pois todas as células que as representam estão sempre contidas na área disciplinar de projeto. Destaca-se também que algumas disciplinas de projeto apresentaram cor rosa escura por tratarem diretamente da temática da sustentabilidade.

Logo, pode-se apreender do diagrama que no curso da UFRN a temática da sustentabilidade é trabalhada em muitas atividades práticas de projeto, reflexo claro do trabalho de integração horizontal e vertical realizado entre as disciplinas do curso.

A seguir, no gráfico contido na Figura 14, apresenta-se a análise da carga horária do curso, baseados no currículo A-5, vigente até 2011.

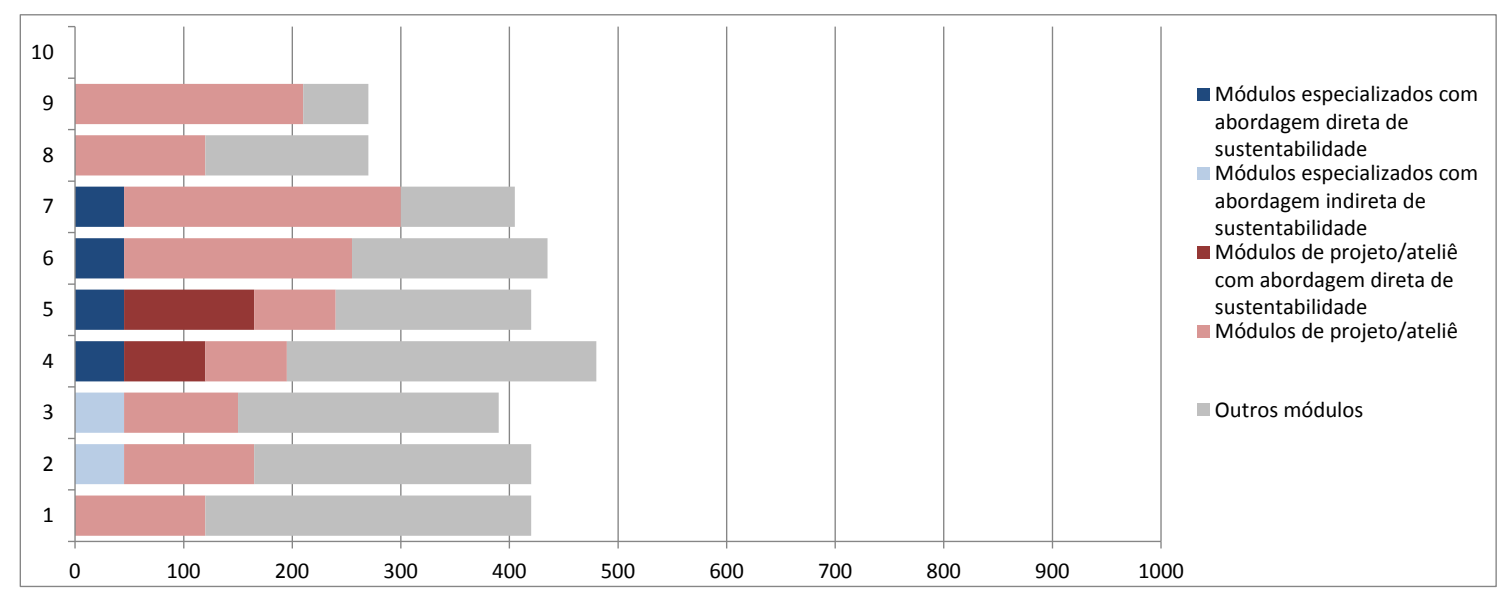

Figura 14: Carga horária da UFRN das disciplinas obrigatórias por tipo e período, em horas-aula

A partir do gráfico podemos chegar às seguintes observações sobre o currículo:

- do primeiro ao terceiro período do curso a abordagem da sustentabilidade ambiental acontece apenas de forma indireta.

- do quarto período até o sétimo, a temática começa a ser trabalhada de forma direta e também passa a ser abordada diretamente em algumas disciplinas de projeto/ateliê.

- Foi identificada a disponibilidade de apenas 3 disciplinas eletivas voltadas à temática da sustentabilidade, de acordo com documentação disponível sobre o período de análise. Entende-se que esta pequena oferta está relacionada à pouca flexibilidade que o curso oferece até o oitavo período, restando principalmente o nono e décimo períodos para cursar as disciplinas eletivas. 
- a partir do oitavo período não identifica-se mais abordagem da sustentabilidade em disciplinas obrigatórias, acontecendo apenas de forma indireta em projeto. Contudo, é possível que o estudante continue trabalhando a temática dentro das disciplinas eletivas (especializadas e de projeto) e dos trabalhos finais de graduação de forma cada vez mais completa, devido à integração vertical.

Logo, observa-se que no curso da UFRN, a integração entre as disciplinas de forma horizontal e vertical estimula uma visão mais generalista e holística do aluno sobre a temática, o que pode ter levado o curso apresentar resultado positivo com relação ao ensino da sustentabilidade.

\subsubsection{Pontos fortes e oportunidades}

Reflete-se no currículo da UFRN alguns princípios considerados fundamentais pelo projeto político pedagógico da FAU/UFRN para a formação do arquiteto-urbanista, como a integração vertical e horizontal das disciplinas obrigatórias do curso e o caráter generalista e interdisciplinar da formação profisssional em nível de graduação.

A integração, metodologia utilizada nas cinco áreas de conhecimento, otimiza a formação de um profissional com caráter generalista, criativo e dotado de visão crítica; fortalece um comprometimento com questões de ordem social, ambiental e econômica, intrínsecas à produção do edifício e do planejamento urbano e regional. Esse aspecto metodológico reforça a percepção, em termos de importância, da proteção do equilíbrio natural e também da utilização racional dos recursos disponíveis.

Importante destacar que uma das principais características da experiência da integração é que esta depende do esforço conjunto dos docentes no sentido da compatibilização do conhecimento a ser repassado e de mostrar aos estudantes o quão abrangente e globalizante é a visão do arquiteto.

Desta forma a UFRN põe em prática uma das orientações do Guidelines on Education Policy for Sustainable Built Environments (UNEP, 2010) que é de promover métodos de ensino para refletir o caráter holístico da educação para sustentabilidade e destacar os fatores interdependentes da arquitetura com o meio ambiente. 


\subsubsection{Curso de Arquitetura e Urbanismo da UFRGS}

\subsubsection{Objetivos educacionais}

Segundo a UFRGS (2013), o curso de Arquitetura e Urbanismo desta universidade tem por objetivo a formação de profissionais aptos a organizar o ambiente físico em correspondência às necessidades sociais e condicionamentos do ambiente natural e construído. Esta atividade, que envolve a produção de edificações isoladas ou em conjunto, bem como a organização do espaço urbano, em qualquer escala ou dimensão, implica na elaboração de estudos, projetos e planos, com os respectivos detalhamentos e execução.

\subsubsection{Breve descrição do curso}

As disciplinas do curso se subdividem em três áreas de interesse: Arquitetura, Tecnológicas e Urbanismo.

No currículo da UFRGS as disciplinas eletivas e atividades complementares tem uma participação muito pequena no currículo mínimo, o que indica que o perfil dos profissionais formados tende a ser semelhante, ou seja, o currículo é pouco flexível o que dificulta ao aluno focar nas disciplinas de maior interesse.

\subsubsection{Estrutura curricular do curso}

Considerando o currículo vigente no período analisado, foi verificado que a carga horária mínima para a conclusão do curso corresponde a 4.500 horas-aula. Da carga horária total, 150 h.a. (3,4\%) são provenientes das disciplinas eletivas, 90 h.a. (2\%) de atividades complementares e as demais 4.260 h.a. (94,6\%) de disciplinas obrigatórias (ver Tabela 8).

Tabela 8: Carga horária mínima exigida no curso da UFRGS

\begin{tabular}{|l|r|r|}
\hline & Créditos & Carga horária \\
\hline Obrigatórias & 260 & 4260 \\
\hline Eletivas & 10 & 150 \\
\hline Atividades complementares & 6 & 90 \\
\hline Total Geral & $\mathbf{2 7 6}$ & $\mathbf{4 5 0 0}$ \\
\hline
\end{tabular}

A estrutura curricular do curso de Arquitetura e Urbanismo da FAU-UFRGS está no Anexo 04 desta dissertação de mestrado. 
5.2.2.4 Sustentabilidade ambiental na estrutura curricular, em cada ano de evolução do curso de graduação, incluindo a descrição do conteúdo, método de ensino e critérios de avaliação.

A Tabela com os detalhes da abordagem da sustentabilidade ambiental no currículo da UFRGS consta no Apêndice 04 desta dissertação.

5.2.2.5 Integração da temática da sustentabilidade com o ateliê de projetos, indicando o nível de integração dos conteúdos técnicos ensinados com aplicações em ateliê de projetos 


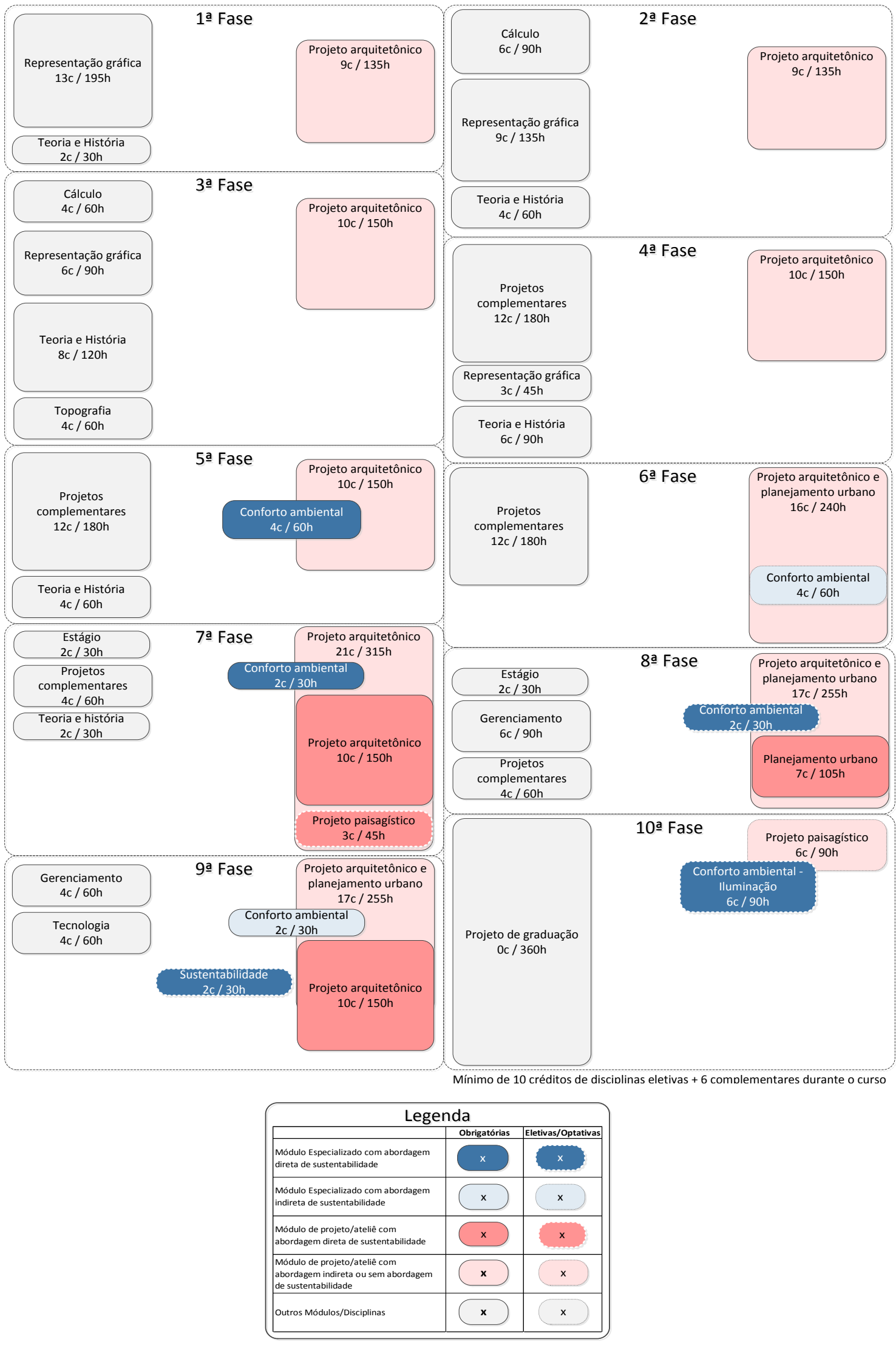

Figura 15: Diagrama representativo da integração entre as disciplinas especializadas e a prática de projeto no currículo do curso da UFRGS 
Observa-se no diagrama acima que as disciplinas especializadas em sustentabilidade estão, em sua maioria, parcialmente integradas às atividades práticas de projeto em ateliê. E algumas disciplinas de projeto apresentaram cor rosa escuro por tratarem diretamente da temática da sustentabilidade.

Logo, pode-se apreender do diagrama que no curso da UFRGS a temática da sustentabilidade é trabalhada em atividades práticas de projeto.

A seguir, no gráfico contido na Figura 16 apresenta-se a análise da carga horária do curso, baseados no currículo vigente até 2011.

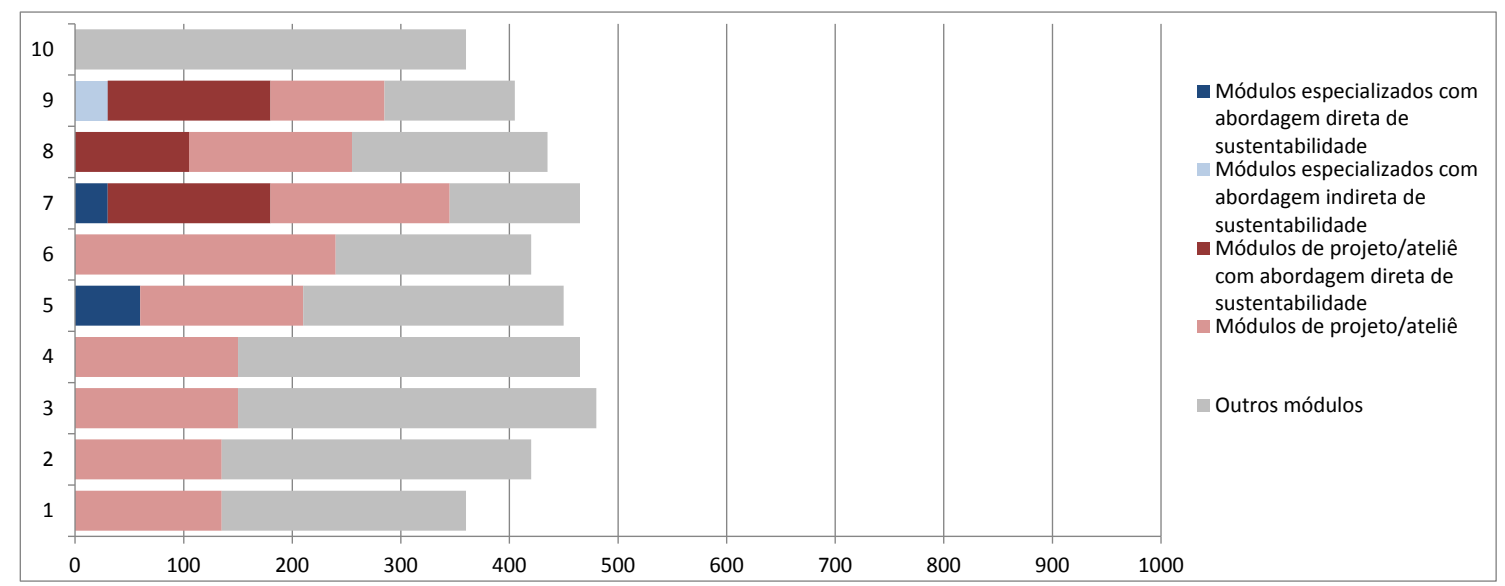

Figura 16: Carga horária da UFRGS das disciplinas obrigatórias por tipo e período, em horas-aula

A partir do gráfico acima podemos tirar as seguintes conclusões sobre o currículo:

- só a partir do quinto período a abordagem da sustentabilidade ambiental foi identificada. Este é o curso analisado que começa a abordar a temática mais tardiamente.

- do quinto ao nono período vemos que a temática começa a ser trabalhada aos poucos, o que vai se intensificando a partir do sétimo período quando conseguimos identificar disciplinas de projeto que passam a tratar da temática de forma direta e com uma carga horária mais razoável.

- Foram identificadas 7 disciplinas eletivas voltadas à temática da sustentabilidade, de acordo com documentação disponível. Contudo, as disciplinas eletivas têm uma participação muito pequena no currículo mínimo da UFRGS $(3,4 \%)$, sendo realizadas sempre em baixas quantidades por cada aluno. 
No currículo, como um todo, observa-se que a carga horária voltada à sustentabilidade em disciplinas especializadas é muito pequena. Logo, conclui-se que os principais conhecimentos referentes à temática da sustentabilidade estejam sendo adquiridos em disciplinas de projeto.

\subsubsection{Pontos fortes e oportunidades}

Aparentemente, um dos diferenciais do curso da UFRGS é a metodologia de ensino utilizada em disciplinas de projeto, pois a oferta de disciplinas especializadas no curso é muito pequena para responder sozinha pelos bons resultados alcançados pelo curso. Segundo Zanin e Cruz (2009) a principal experimentação no ensino da sustentabilidade identificada curso da UFRGS vem sendo aplicada desde 2005 na Disciplina de Projeto Arquitetônico VII, disciplina vigente no período analisado. Na disciplina citada realizamse, sistematicamente, ciclos de palestras, visitas técnicas, oficinas, pesquisas, assessoria com especialistas, contatos com os pretensos usuários. E, a cada semestre, são selecionados convidados especiais que virão a colaborar no sentido de permitir aos estudantes compreender o que estão sendo solicitados na disciplina e a riqueza que poderia resultar de sua dedicação.

Nesta disciplina, em todos os semestres busca-se realizar uma parceria, verbal ou conveniada, com um pretenso cliente real. A escolha do cliente prima pela diversidade de temas ou parcerias. Ao final do semestre é promovido um evento para a escolha e premiação dos melhores projetos. O cliente real também confere ao exercício um caráter de profissionalismo, uma vez que um dos projetos desenvolvidos na disciplina poderá ser construído quando o estudante estiver graduado e registrado junto ao conselho de classe. Um cliente real conduz os professores a estarem constantemente se atualizando. Também buscou-se realizar exercícios que pudessem atender comunidades menos favorecidas, oportunizando aos estudantes e à própria universidade, um retorno à sociedade. Desta forma, coloca-se em prática uma das estratégias apontadas pelo Guidelines on Education Policy for Sustainable Built Environments (UNEP, 2010), de reforçar o envolvimento com a comunidade buscando estudos de caso e aplicações reais fora da universidade.

Outro diferencial nesta disciplina é que os estudantes não são apenas espectadores, mas também tornam-se instrutores de seus colegas, ao receberem a tarefa de pesquisar e transferir informações ao restante da turma, pois em todos os semestres é criado um grupo 
on-line, onde são anexadas as pesquisas desenvolvidas, o relato das palestras, arquivos cedidos pelo cliente, informações relevantes sobre fornecedores, para a elaboração dos projetos, entre outros. O objetivo principal do grupo é ser mais uma ferramenta para exercitar a cooperação, no lugar da competição.

Quando foi realizado levantamento sobre o ensino da sustentabilidade na FAU/UFRGS também foi identificado que frequentemente os alunos apresentam seus trabalhos de forma pública para professores e colegas, configurando o chamado Painel de Assessoramento ou Painel Expositivo, critério de avaliação usual na UFRGS. Essas apresentações também representam um diferencial, pois servem como momento de crítica, dando condições de um melhor direcionamento das propostas, e oportuniza aos estudantes o treinamento da exposição oral em público, por meio da apresentação de suas pesquisas e projetos em desenvolvimento.

\subsubsection{Curso de Arquitetura e Urbanismo da USP}

\subsubsection{Objetivos educacionais}

Segundo o projeto político pedagógico da FAU/USP (2010) o curso tem por missão formar profissionais arquitetos e urbanistas aptos a responder pelas demandas mais complexas da sociedade em relação a matérias de interesse público e ambiental que requeiram habilidades específicas na formulação de planos e projetos de desenvolvimento, conservação ou restauro dos espaços construídos e dos sistemas urbanos e ambientais.

\subsubsection{Breve descrição do curso}

O curso de graduação da FAU-USP é ministrado por três departamentos que compõem a faculdade. Nos departamentos, as disciplinas obrigatórias e eletivas estão distribuídas da seguinte forma:

1-Departamento de Projeto (AUP) - Possui carga didática que envolve prioritariamente a transmissão de conhecimentos diretamente ligados à criação e desenvolvimento de projetos de edifícios, em todas suas escalas de inserção, no ambiente, de projetos e planos urbanos e regionais, projetos e planos paisagísticos e de projetos de programação visual, desenho industrial e desenho urbano. O Departamento é responsável por $57 \%$ da carga didática do curso. 
2-Departamento de História da Arquitetura e Estética do Projeto (AUH) -Tem como ponto de partida a relação entre o contexto social (econômico, político, cultural e ideológico) e sua relação na atividade do arquiteto e urbanista, desenvolvendo e apresentando conceitos de história da arquitetura e do urbanismo, associados à estética, à arte e à técnica.

3-Departamento de Tecnologia da Arquitetura (AUT) - É responsável pela parte mais essencialmente tecnológica da formação profissional referida às questões da construção do espaço edificado, sob os aspectos da tecnologia construtiva, do conforto ambiental, e das metodologias de avaliação e planejamento das edificações e da urbanização.

Um diferencial na estrutura curricular da FAU-USP é que as disciplinas eletivas de projeto são ofertadas com prioridade para alunos do $8^{\circ}$ e $9^{\circ}$ semestres. Tal organização possibilita que cada aluno possa desenvolver um perfil profissional mais especializado em determinado tema no momento conclusão do curso, ou seja, as últimas disciplinas podem ser direcionadas pelo interesse individual dos alunos e também voltadas ao tema do trabalho final escolhido por cada um. Desta forma, o curso se caracteriza por oferecer um pouco mais de flexibilidade no ensino com uma grande oferta de disciplinas eletivas.

\subsubsection{Estrutura curricular do curso}

Observa-se, na tabela abaixo, que a carga horária mínima do curso corresponde a 5.880 horas-aula, sendo 600 h.a. $(10,2 \%)$ provenientes das disciplinas eletivas e as demais $5280(89,8 \%)$ de disciplinas obrigatórias (ver Tabela 9).

Tabela 9: Créditos e carga horária necessários para a conclusão do curso de Arquitetura e Urbanismo na USP

\begin{tabular}{|l|l|r|}
\hline & Créditos & \multicolumn{2}{|l|}{ Carga horária } \\
\hline Obrigatórias & 312 & 5280 \\
\hline Eletivas & & 600 \\
\hline Total Geral & & $\mathbf{5 8 8 0}$ \\
\hline
\end{tabular}

A estrutura curricular do curso de Arquitetura e Urbanismo da FAU-USP está no Anexo 05 desta dissertação de mestrado. 
5.2.3.4 Sustentabilidade ambiental na estrutura curricular, em cada ano de evolução do curso de graduação, incluindo a descrição do conteúdo, método de ensino e critérios de avaliação

A Tabela com os detalhes da abordagem da sustentabilidade ambiental no currículo da USP consta no Apêndice 05 desta dissertação.

5.2.3.5 Integração da temática da sustentabilidade com o ateliê de projetos, indicando o nível de integração dos conteúdos técnicos ensinados com aplicações em projetos 


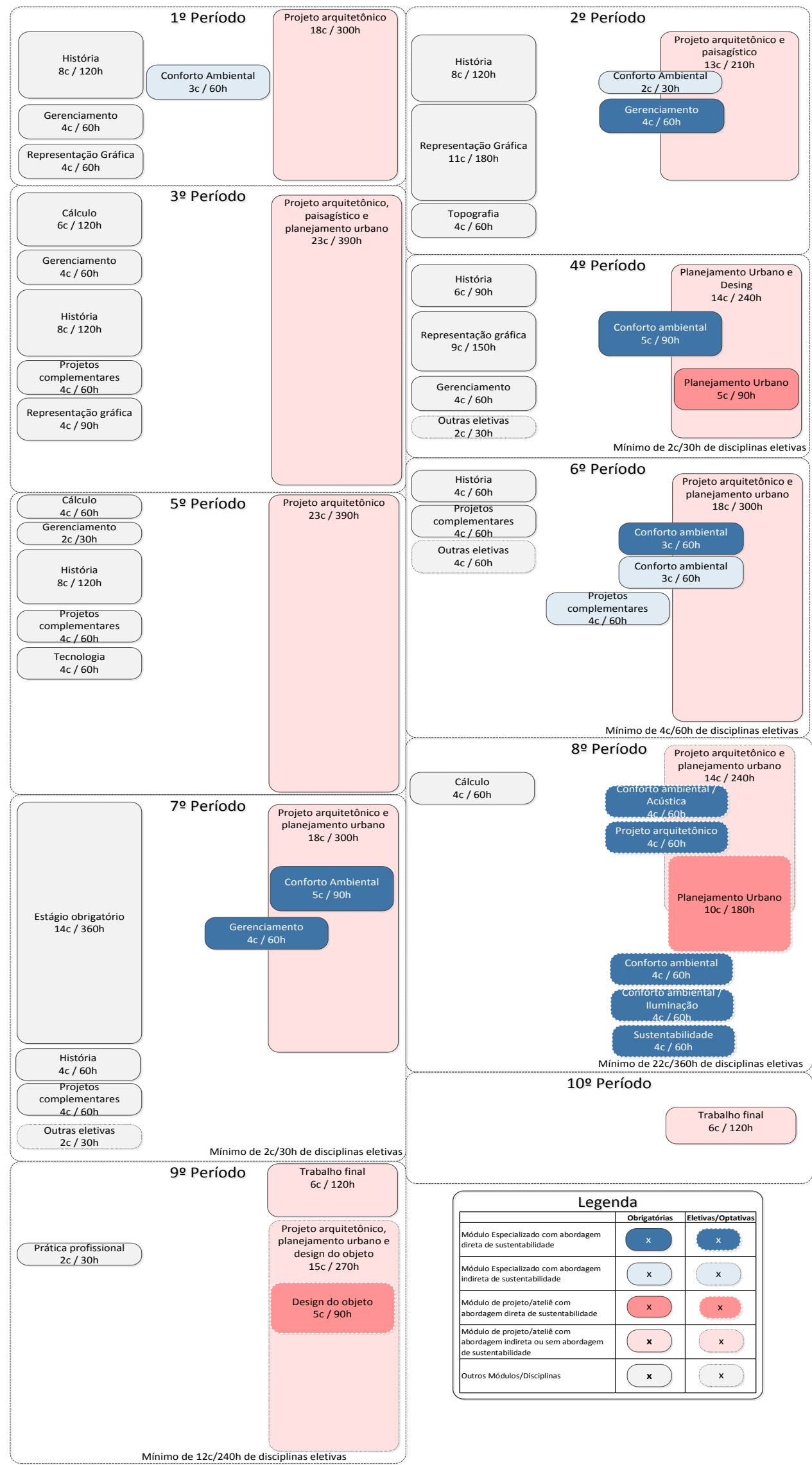

Figura 17: Diagrama representativo da integração entre as disciplinas especializadas e a prática de projeto no currículo do curso da USP 
Observa-se no diagrama acima que as disciplinas especializadas em sustentabilidade estão, em sua maioria, parcialmente integradas com as atividades práticas de projeto em ateliê. Observando-se as disciplinas de projeto, apenas uma obrigatória tratou diretamente da temática.

Em análise anterior publicada pelo EDUCATE (2012 d), que considerou apenas as disciplinas especializadas de Conforto Ambiental, o currículo foi classificado como Satélite/Linear, pois não foi identificada integração relevante destas disciplinas com a prática de projeto. Porém, observando-se o currículo vigente em 2011 e analisando todas as disciplinas que abordaram a temática da sustentabilidade incluindo as disciplinas de projeto, podemos observar que há integração parcial com a prática de projeto.

Logo, pode-se apreender do diagrama que no curso da USP existem algumas formas de integração da sustentabilidade com atividades práticas de projeto.

A seguir, no gráfico da Figura 18, apresenta-se a análise da carga horária do curso, baseados no currículo vigente até 2011.

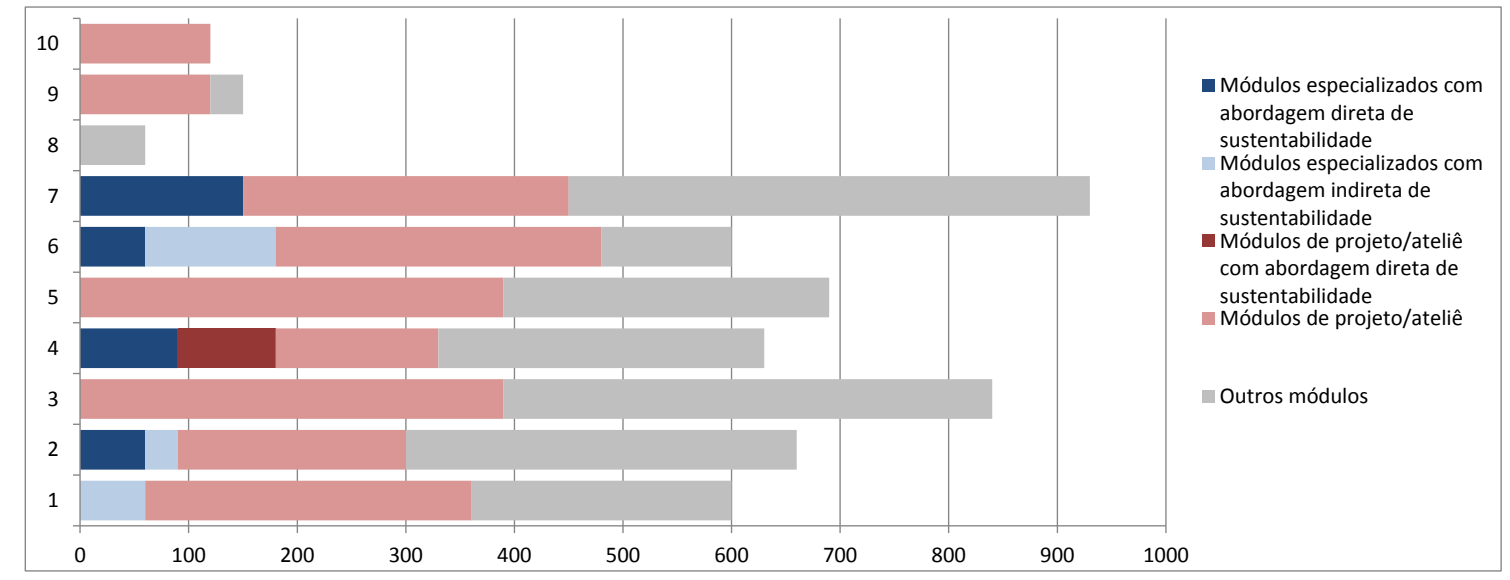

Figura 18: Carga horária da USP das disciplinas obrigatórias por tipo e período, em horasaula

A partir do gráfico acima, podemos retirar as seguintes conclusões sobre o currículo:

- desde o início do curso aborda-se a sustentabilidade, de forma direta e indireta. 
- do quarto ao sétimo período observa-se uma intensificação na abordagem da sustentabilidade. Há a ampliação na quantidade de horas-aula dedicadas à temática e a abordagem passa a acontecer, predominantemente, de forma direta.

- observa-se a existência de apenas uma disciplina de projeto/ateliê abordando diretamente a sustentabilidade ambiental, mas existem algumas eletivas com este perfil.

- do oitavo período ao fim do curso não observa-se mais a presença da temática nas disciplinas obrigatórias. Contudo, nesse período ampliam-se as possibilidades para o aluno estar se aprimorando na temática por meio de disciplinas eletivas, já que desde 2004 foi ampliada a oferta de disciplinas eletivas no curso visando suprir a demanda de maior especialização em alguns temas.

- Logo, foram identificadas 11 disciplinas eletivas voltadas à temática da sustentabilidade de acordo com documentação disponível no período da análise. É característica do curso ofertar estas disciplinas com prioridade aos alunos do oitavo e nono semestres, pois partiu-se do princípio de que temas específicos poderiam ser melhor aprofundados quando os alunos já assimilaram bem os conceitos iniciais.

\subsubsection{Pontos fortes e oportunidades}

Segundo o projeto político pedagógico da FAU/USP, o curso de Arquitetura e Urbanismo da USP possui currículo de graduação que abrange conteúdos inovadores de ciências sociais aplicadas, de tecnologia e de prática de projeto não contemplados nos currículos mínimos oficiais e na maioria dos cursos existentes. Na área de tecnologia, por exemplo, os conteúdos são vinculados a disciplinas da Escola Politécnica e ao Instituto de Matemática e Estatística, o que possibilita uma maior integração extra departamental.

Professores da USP, Gonçalves e Duarte (2006) identificaram que no cenário comum de compartimentação das disciplinas relacionadas ao projeto, surge a necessidade de uma disciplina obrigatória de ateliê integrando todas as áreas do projeto. Logo, a disciplina de Conforto Ambiental Integrado 6 (especializada) foi desenvolvida para resolver as questões de conforto ambiental e sustentabilidade em desenvolvimento junto com disciplina de projeto. Destaca-se que foram desenvolvidos nessa disciplina os quatro trabalhos da FAUUSP classificados na Bienal Miguel Aroztegui -2005. 
Neste sentido, os autores qualificaram como positivas experiências realizadas na FAUUSP com a participação de professores de Conforto Ambiental em exercícios de projeto em ateliê. Segundo Gonçalves e Duarte (2006) o trânsito dos professores entre as disciplinas é um dos caminhos para que as questões de conforto e energia sejam incorporadas de uma maneira espontânea no projeto e que não sejam encaradas meramente como uma especialidade ou adendo a ser considerado ou não.

Juntamente com a elaboração de uma base conceitual sólida, os exercícios de projeto foram enriquecidos técnica e cientificamente por uma série de estudos analíticos. Muitos deles foram baseados em simulações computacionais, a fim de testar a veracidade das soluções propostas para o conforto ambiental e a consequente eficiência energética.

Outra oportunidade se apresentou nos trabalhos finais de graduação dos estudantes envolvidos com trabalhos no LABAUT (Laboratório de Conforto Ambiental e Eficiência Energética). Estes assumiram a tarefa de pensar uma arquitetura inovadora tomando o conforto ambiental e a eficiência energética como prioridade.

Na USP destaca-se também boa carga horária destinada a atividades complementares, dentre elas, os Trabalhos Monitorados e Estágio Obrigatório, cuja carga horária mínima deve ser de 360 h.a.

\subsubsection{Curso de Arquitetura e Urbanismo da UnB}

\subsubsection{Objetivos educacionais}

Segundo o projeto político pedagógico da UnB, cabe ao ensino de graduação estabelecer a relação entre os conhecimentos produzidos na universidade e as demandas do mundo do trabalho, desde os primeiros períodos curriculares, desenvolvendo práticas pedagógicas e atividades acadêmicas que contribuam para a consolidação da formação profissional do egresso.

A FAU/UnB tem como finalidade o desenvolvimento, a transmissão e a difusão da cultura, da ciência e da tecnologia da área da Arquitetura e Urbanismo, colocando-os a serviço da sociedade, respeitando os direitos humanos e visando à preservação do ambiente natural e cultural (FAU/UNB, 2008). 
Os cursos devem buscar a interdisciplinaridade e a flexibilidade dos currículos, formando profissionais aptos para trabalhar com a diversidade. Nesse sentido, deve-se fortalecer a política de mobilidade estudantil com outras Instituições de Ensino Superior (IES) no país e a política de intercâmbio estudantil com instituições de ensino no exterior.

A FAU UNB deve responder às expectativas geradas a partir de sua condição específica e singular. Seu campo de ação é o da responsabilidade social e da luta por um espaço qualificado, não podendo se restringir a apenas ao local, ao distrital ou ao regional. Trata-se de uma escola de importância nacional e internacional, que tem Brasília primordialmente - como centro de reflexão e projeção.Ficam assim definidas três matrizes de desenho curricular:

- A da formação do gestor público

- A da formação do artista comprometido

- A da formação do cidadão consciente da necessidade de utilização racional dos recursos disponíveis

\subsubsection{Breve descrição do curso}

A Faculdade de Arquitetura e Urbanismo possui os seguintes Departamentos didáticos:

- Departamento de Projeto e de Expressão e Representação em Arquitetura e Urbanismo;

- Departamento de Teoria e História em Arquitetura e Urbanismo;

- Departamento de Tecnologia em Arquitetura e Urbanismo.

Para a integralização curricular estão previstas:

-disciplinas obrigatórias

-disciplinas obrigatórias seletivas e optativas - aquelas que o aluno deverá escolher para cursar uma dentre as disciplinas constantes em cada cadeia de seletividade, a saber: de expressão e representação; projeto; teoria e história e tecnologia. Logo, as demais disciplinas constantes em cada cadeia serão consideradas optativas. (para efeito das análises nesta dissertação de mestrado, ambas foram consideradas como disciplinas eletivas) 
-disciplinas de módulo livre - quaisquer outras disciplinas oferecidas pela UnB. O limite máximo de integralização das disciplinas de módulo livre é de 360 horas-aula. Monitorias entram nesta modalidade.

- atividades complementares - atividades realizadas fora do âmbito da sala de aula que a Comissão de Graduação da FAU considere pertinentes para integralização curricular, como cursos, estágios, participação em congressos. A atividade deve ser passível de comprovação e ter explícita sua carga horária. Analisadas caso a caso.

\subsubsection{Estrutura curricular do curso}

A partir do currículo vigente na FAU-UnB em 2008 a carga horária mínima do curso corresponde a 4.110 horas-aula, sendo 780 h.a (19\%) provenientes das disciplinas eletivas (obrigatórias seletivas e optativas) e as demais 3330 (81\%) de disciplinas obrigatórias (ver Tabela 10).

Tabela 10: Créditos e carga horária mínima exigida no curso da UnB

\begin{tabular}{|l|r|r|}
\hline & \multicolumn{1}{|c|}{ Créditos } & \multicolumn{1}{c|}{ Carga horária } \\
\hline Obrigatórias & 222 & 3330 \\
\hline $\begin{array}{l}\text { Eletivas (Obrigatórias seletivas + } \\
\text { optativas/ módulo livre/ atividades } \\
\text { complementares) }\end{array}$ & & \\
\hline Total Geral & $18+34$ & $270+510$ \\
\hline
\end{tabular}

A estrutura curricular do curso de Arquitetura e Urbanismo da FAU-UnB está no Anexo 06 desta dissertação de mestrado.

5.2.4.4 Sustentabilidade ambiental na estrutura curricular, em cada ano de evolução do curso de graduação, incluindo a descrição do conteúdo, método de ensino e critérios de avaliação

A Tabela com os detalhes da abordagem da sustentabilidade ambiental no currículo da UNB consta no Apêndice 06 desta dissertação.

5.2.4.5 Integração da temática da sustentabilidade com o ateliê de projetos, indicando o nível de integração dos conteúdos técnicos ensinados com aplicações em projetos 


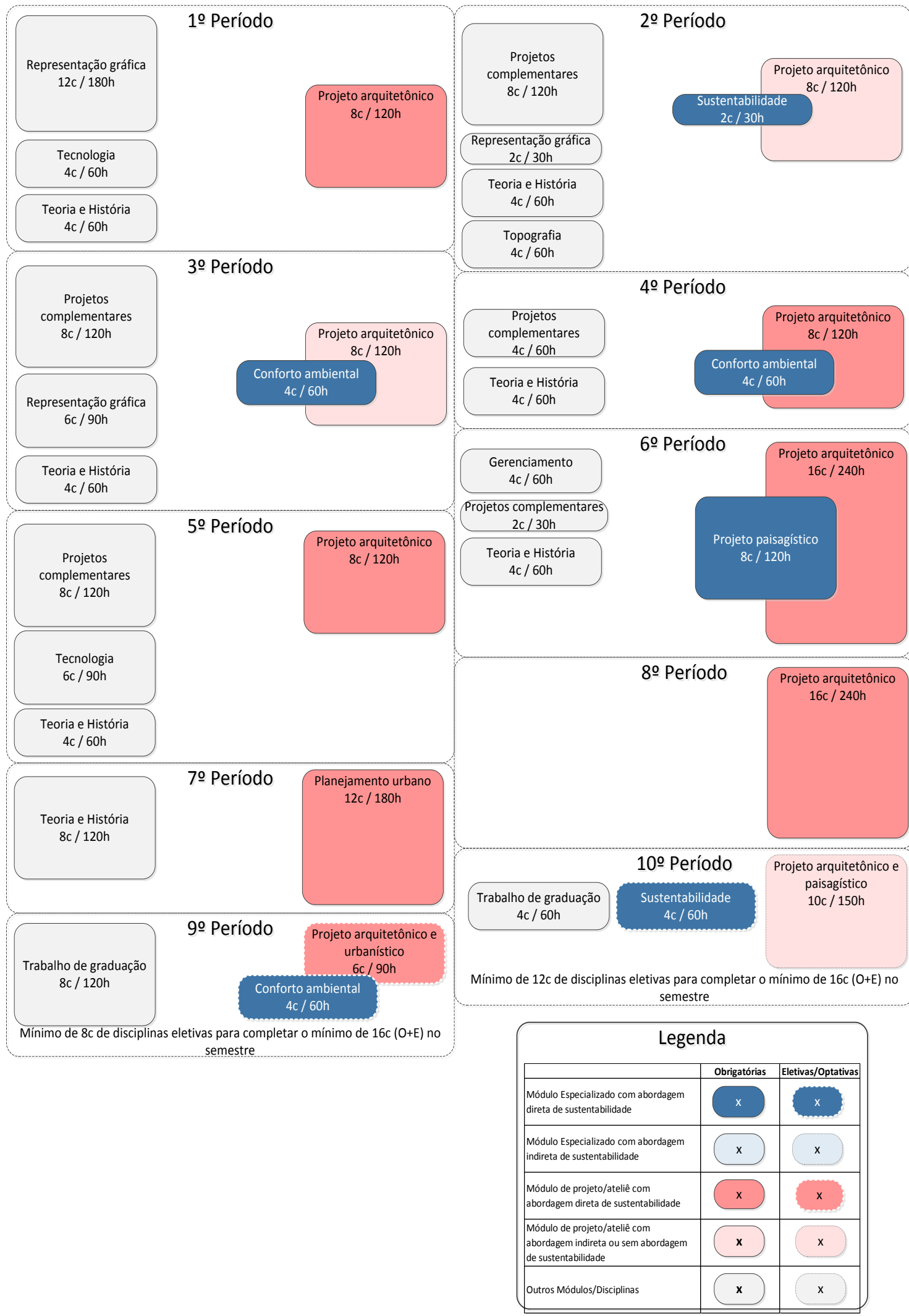

Figura 19: Diagrama representativo da integração entre as disciplinas especializadas e a prática de projeto no currículo do curso da UnB 
Observa-se no diagrama acima que as disciplinas especializadas em sustentabilidade estão, em sua maioria, parcialmente integradas às atividades práticas de projeto em ateliê. Além disso, destaca-se que a grande maioria das disciplinas de projeto tratam diretamente da sustentabilidade em seus conteúdos.

Logo, pode-se apreender do diagrama que no curso da UnB a integração das disciplinas especializadas com atividades práticas de projeto é frequente.

A seguir, no gráfico da Figura 20, apresenta-se a análise da carga horária do curso, baseados no currículo vigente até 2011.

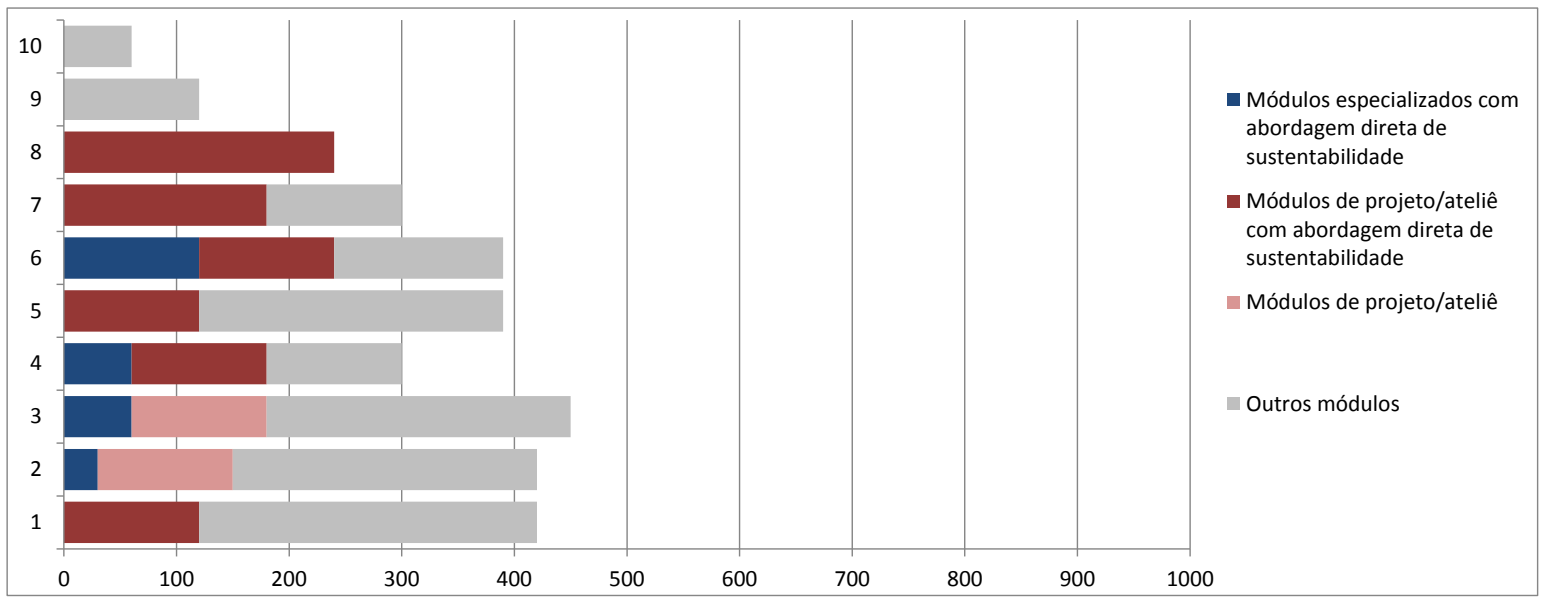

Figura 20: Carga horária da UnB das disciplinas obrigatórias por tipo e período, em horasaula

A partir do gráfico acima podemos retirar as seguintes conclusões sobre o currículo:

- desde o início do curso a sustentabilidade é abordada e de forma direta.

- do quarto período ao sexto, observa-se uma ampliação na abordagem da temática.

- a partir do sétimo verifica-se a intensificação da abordagem direta do tema em disciplinas de projeto, corroborando com a ideia de que ao final do curso a temática tem chance de ser melhor trabalhada em projeto.

Observa-se no currículo da UnB que as abordagens ao tema aconteceram sempre de forma direta, além da existência de poucas disciplinas de projeto em que não se abordou a sustentabilidade de forma direta. Tal observação indica uma grande importância da temática dentro do currículo deste curso. 
$\mathrm{Na}$ UnB, a regra é fazer no mínimo 16 créditos por semestre, somando obrigatórias e eletivas. Contudo, até o oitavo semestre, a quantidade de créditos das obrigatórias é sempre maior que 16. Logo, há mais chances dos alunos pegarem as eletivas no nono e décimo períodos. No nono ele necessita pegar no mínimo 8c de eletivas e no décimo 12c. Logo, o mínimo para concluir o curso seriam 300 horas-aula de eletivas, sendo a oferta de disciplinas eletivas que abordam a sustentabilidade igual a 360 h.a. Foram identificadas 5 disciplinas eletivas voltadas à temática da sustentabilidade, de acordo com documentação disponível no período da análise.

\subsubsection{Pontos fortes e oportunidades}

No "Seminário Pacto Coletivo: O Ensino da Arquitetura e Urbanismo na UnB", ocorrido em 2010, ficaram identificados como alguns dos principais pontos do ensino levantados pelo coletivo da FAU (FARIA, 2010):

- necessidade de flexibilização da estrutura curricular;

- flexibilização dos pré-requisitos em disciplinas, sobretudo nas disciplinas obrigatórias seletivas;

- pensar a redução da carga horária das atividades letivas, justificada na ampliação da formação sem que isso signifique a ampliação da carga horária;

- a (re)aproximação com outras áreas de formação, como o desenho industrial

Logo, apesar da flexibilidade e da integração extra departamental serem algumas das principais prerrogativas do ensino no curso da UnB (FAU/UNB,), o que se verifica é a dificuldade de propiciá-los devido a vários aspectos limitadores do currículo.

O primeiro aspecto é o grande número de pré-requisitos para as disciplinas, incluindo as obrigatórias seletivas que deveriam ser as mais flexíveis juntamente com as optativas. Outro aspecto é a baixa carga horária destinada a módulo livre, atividades complementares e eletivas, pois todas estas atividades somadas só correspondem a 12\% da carga horária total, sendo que módulo livre é fundamental para a promoção de uma integração extra departamental. 
Destaca-se que a revisão destas duas condições se apresentam como duas oportunidades de evolução no ensino que agregariam resultado ao ensino da sustentabilidade.

Identificaram-se no curso da UnB duas experiências de integração entre disciplinas visando a melhor inserção da sustentabilidade em projetos arquitetônicos e urbanísticos.

A primeira experiência ocorreu em 2006 com a criação da disciplina optativa intitulada Projeto Ambiental Integrado (P.A.I.). As aulas presenciais desenvolveram-se concomitantemente à disciplina de Projeto de Arquitetura 5 (obrigatória do quinto período) objetivando a integração, durante o desenvolvimento do projeto, dos conceitos apresentados na disciplina P.A.I. (disciplina especializada).

Segundo Amorim et al (2008) em questionário de avaliação aplicado aos alunos da disciplina P.A.I., verificou-se como aspectos positivos o aprimoramento nos projetos das relações entre: edifício/luz natural; tratamento fachadas/luz natural; forma urbana/conforto térmico; aspectos da ventilação; forma urbana/ luz natural. Foram utilizados instrumentos de projeto como software Ecotect, Carta Solar, software SolAr e Carta Bioclimática. Quanto à fase de projeto que recebeu maior contribuição devido à integração das disciplinas, os alunos em sua maioria apontaram o Anteprojeto (72\%) e Estudo Preliminar $(67 \%)$.

Ao final foi verificado o aumento do interesse dos alunos na temática e o consequente aumento da qualidade dos projetos apresentados em termos ambientais. Ressalta-se que da turma do primeiro semestre de 2007, 3 projetos foram selecionados e enviados à Bienal Miguel Aroztegui, sendo que 2 foram selecionados para a mostra Itinerante.

$\mathrm{Na}$ experiência de Andrade et al (2013) foi aplicada metodologia de projeto de integração aos projetos urbanísticos desenvolvidos por estudantes do $4^{\circ}$ semestre da FAU/UNB com a integração transversal das disciplinas de Projeto de Urbanismo 1, Conforto térmico, Infraestrutura e Projeto de Paisagismo 1.

Detectou-se como a mais rica contribuição da integração a sensibilidade desenvolvida pelos alunos para perceber os recursos ambientais disponíveis, permitindo que o desenho urbano gerado seja capaz de potencializar o bom desempenho do microclima local. 
Nas duas experiências de ensino realizadas, apesar de uma série de aspectos positivos, houve dificuldade de todos os alunos estarem simultaneamente matriculados em todas as disciplinas envolvidas no processo, o que gerou um problema de integração entre as disciplinas, principalmente se uma grande parcela de alunos não está matriculada na disciplina em que se desenvolvem os projetos arquitetônicos ou urbanísticos.

Logo, a transversalidade entre as disciplinas tem muito a evoluir, mas a motivação para a integração é que o conteúdo da sustentabilidade é transdisciplinar, o que torna imprescindível uma conexão maior entre as disciplinas e entre os professores para promover uma educação voltada à busca de projetos mais sustentáveis.

\subsubsection{Análise comparativa dos quatro cursos analisados}

Após serem realizadas análises individuais sobre o ensino da sustentabilidade em cada curso selecionado, foram também realizadas análises comparativas entre os quatro cursos focando as informações de interesse o ensino da sustentabilidade, dentre elas:

- carga horária destinada à temática da sustentabilidade;

- integração entre as disciplinas especializadas e a prática de projeto;

- período de inserção da temática no currículo;

- métodos de ensino mais utilizados nos cursos analisados;

- critérios de avaliação mais utilizados nos cursos analisados.

É importante destacar que nas análises desta dissertação de mestrado não existiu a intenção de criticar qualquer curso, pelo contrário, apontar os potenciais e diferenciais dos mesmos para que sejam modelos para cursos em elaboração ou etapa de revisão, diferenciais estes, que só foram possíveis a identificação através das análises e comparações.

A primeira análise comparativa entre os cursos refere-se à carga horária. Foram consideradas como foco principal da análise as disciplinas especializadas, conforme método do EDUCATE. As disciplinas de projeto também foram identificadas nesta análise, porém estão todas agrupadas, independentemente se abordam ou não a 
sustentabilidade. Considerou-se a carga horária por tipo de disciplina para cada curso analisado (especializada, projeto/ateliê, outra), conforme pode ser verificado na Tabela 11 a seguir:

Tabela 11: Carga horária por tipo de disciplina e curso

\begin{tabular}{|r|r|r|r|r|r|}
\hline & \multicolumn{1}{|c|}{ Tipo } & UFRN & UFRGS & \multicolumn{1}{c|}{ USP } & \multicolumn{1}{c|}{ UNB } \\
\hline \multirow{4}{*}{ Obrigatórias } & Especializada & 270 & 120 & 570 & 270 \\
\cline { 2 - 6 } & Projeto/ateliê & 1485 & 1785 & 2370 & 1140 \\
\cline { 2 - 6 } & Outra & 1755 & 2355 & 2340 & 1680 \\
\cline { 2 - 6 } & Total das obrigatórias & $\mathbf{3 5 1 0}$ & $\mathbf{4 2 6 0}$ & $\mathbf{5 2 8 0}$ & $\mathbf{3 0 9 0}$ \\
\hline & Especializada Eletiva & 90 & 210 & 300 & 120 \\
\hline
\end{tabular}

Considerando a Tabela 11 acima, observa-se que o curso da USP possui a maior carga horária em disciplinas especializadas na temática da sustentabilidade (570 h.a.) e o curso da UFRGS possui a menor carga horária (120 h. a.), inferior à metade das cargas horárias da UnB e UFRN (270 h.a), como pode ser melhor visualizado na Figura 21.

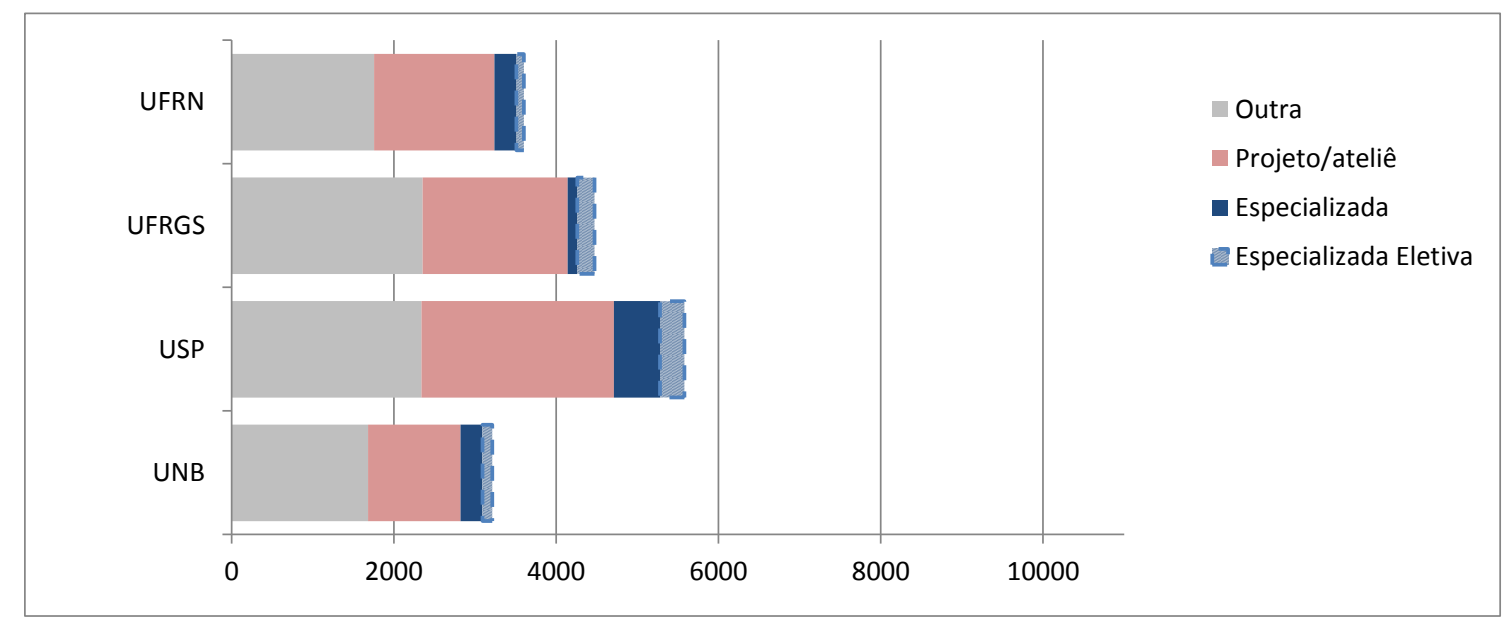

Figura 21: Carga horária das disciplinas especializadas (obrigatórias e eletivas), por tipo, por curso

Com relação às disciplinas especializadas eletivas, foi identificado, em quase todos os cursos, um quantitativo razoável de oferta das mesmas, correspondente a mais de $50 \%$ da carga horária das especializadas obrigatórias. A UFRN foi a única que apresentou porcentagem inferior por possuir apenas 3 disciplinas eletivas com abordagem da sustentabilidade. A USP possui 11 disciplinas especializadas eletivas ofertadas, a maior quantidade dentre os cursos. 
A segunda análise comparativa entre os cursos também refere-se à carga horária, porém nesta análise foram consideradas todas as disciplinas que abordaram a temática da sustentabilidade (de qualquer tipo, inclusive disciplinas de projeto). A análise também incluiu a identificação das disciplinas que abordaram a sustentabilidade de forma direta (forma clara e frequente) e indireta (eventual, ou associada a outras temáticas importantes). Desta forma, estão incluídas duas análises adicionais às realizadas pelo EDUCATE, representando uma evolução à metodologia original, conforme detalhado na Seção 3.5. Logo, foi analisada a carga horária dos cursos por abordagem da sustentabilidade.

Tabela 12: Carga horária por abordagem da sustentabilidade (inclui todas disciplinas que abordam a temática), por curso

\begin{tabular}{|l|l|r|r|r|r|}
\hline \multicolumn{2}{|c|}{ Abordagem da sustentabilidade } & UFRN & UFRGS & USP & UNB \\
\hline \multirow{2}{*}{$\begin{array}{l}\text { Disciplinas } \\
\text { Obrigatórias }\end{array}$} & $\begin{array}{l}\text { Com abordagem direta sobre } \\
\text { sustentabilidade }\end{array}$ & 375 & 495 & 450 & 1170 \\
\cline { 2 - 6 } & $\begin{array}{l}\text { Com abordagem indireta } \\
\text { sobre sustentabilidade }\end{array}$ & 855 & 1410 & 600 & 240 \\
\cline { 2 - 6 } & $\begin{array}{l}\text { Total de disciplinas } \\
\text { obrigatórias com abordagem }\end{array}$ & 1230 & 1905 & 1050 & 1410 \\
\hline \multirow{2}{*}{$\begin{array}{l}\text { Disciplinas } \\
\text { Eletivas }\end{array}$} & $\begin{array}{l}\text { Com abordagem direta sobre } \\
\text { sustentabilidade }\end{array}$ & 105 & 195 & 570 & 270 \\
\cline { 2 - 6 } & $\begin{array}{l}\text { Com abordagem indireta } \\
\text { sobre sustentabilidade }\end{array}$ & 45 & 150 & 270 & 90 \\
\cline { 2 - 6 } & $\begin{array}{l}\text { Total de disciplinas } \\
\text { obrigatórias com abordagem }\end{array}$ & 150 & 345 & 840 & 360 \\
\hline $\begin{array}{l}\text { Total da Obrigatórias e Eletivas com } \\
\text { abordagem sobre sustentabilidade (direta } \\
\text { ou indireta) }\end{array}$ & 1380 & $\mathbf{2 2 5 0}$ & $\mathbf{1 8 9 0}$ & $\mathbf{1 7 7 0}$ \\
\hline
\end{tabular}

Considerando a Tabela 12 acima, observa-se que o curso da USP é o que apresenta menor carga horária quando analisadas todas as disciplinas obrigatórias voltadas à temática da sustentabilidade, com abordagem direta e indireta (1050 h.a.), mesmo sendo o curso com a maior carga horária total.

O curso da UFRGS é o que apresenta maior carga horária total voltada à temática (1905 h.a), como pode ser visualizado no gráfico contido na Figura 22 a seguir, gerado a partir da Tabela 12. 


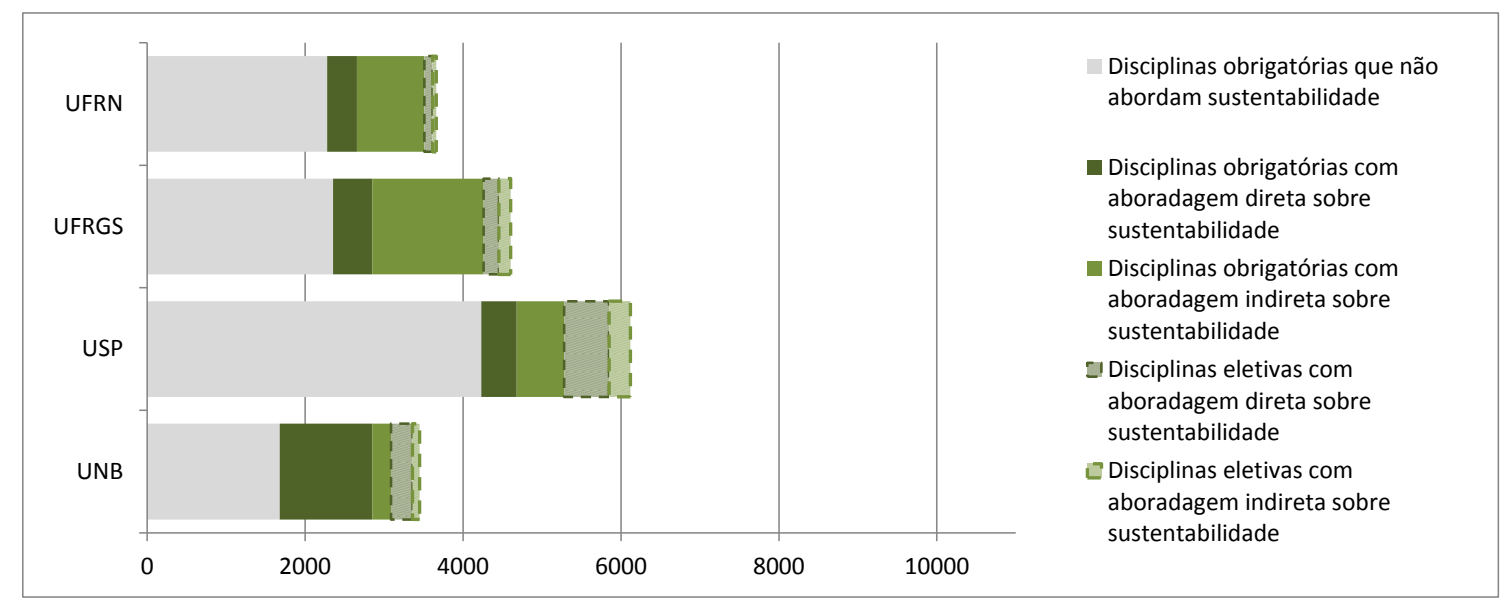

Figura 22: Carga horária das disciplinas por tipo de abordagem da sustentabilidade (inclui todas disciplinas que abordam a temática), por curso

No gráfico acima, a UnB também se destaca pelo fato de que a maioria das disciplinas que abordam a temática da sustentabilidade foram classificadas com abordagem direta da temática (1.440 h.a.), conforme observado anteriormente em análise individual do curso (Seção 5.2.4).

Quanto à USP, reforça-se o que foi levantado na análise individual do curso (Seção 5.2.3), que há uma grande oferta de disciplinas eletivas voltadas à temática da sustentabilidade, tanto especializadas quanto de projeto, o que amplia as possibilidades de abordagem da temática e se justifica pelas características de um curso mais flexível.

Comparando a Figura 21 com a Figura 22 observa-se o quão mais significativa se apresentou a abordagem da sustentabilidade no currículo quando consideramos, além das disciplinas especializadas, todas as disciplinas que abordam a temática da sustentabilidade (incluindo as de projeto). Como observado na revisão bibliográfica, a interdisciplinaridade do tema permite que ele seja trabalhado em diversas áreas disciplinares e a integração com atividades práticas de projeto são essências para a melhor apreensão dos conteúdos, desta forma, entende-se que a segunda análise ficou mais representativa do ensino ofertado.

Dando continuidade à comparação entre as duas análises, foi observado que a USP apresentou a maior carga horária de disciplinas especializadas, contudo a menor carga horária ao consideramos todas as disciplinas que abordam a sustentabilidade. Em contraposição, a UFRGS possui a menor carga horária de disciplinas especializadas e, ao mesmo tempo, a maior carga horária dedicada à temática da sustentabilidade ao 
consideramos todas as disciplinas que abordam a sustentabilidade. Ou seja, na UFRGS trata-se a temática da sustentabilidade com uma maior frequência em disciplinas não especializadas (incluindo projeto em ateliê).

Também pudemos levantar, a partir das análises realizadas que, considerando todas as disciplinas obrigatórias e também as eletivas que abordaram a sustentabilidade de forma direta ou indireta (ou seja a abordagem total da sustentabilidade no currículo) identificamos que, com relação à carga horária total de cada curso, a UFRN abordou a temática em $41 \%$ das disciplinas do currículo, a UFRGS em 51\%, a USP em 32\%, e a UnB em 49\%. Logo, acredita-se que esta é uma referência importante já que números apresentados propiciaram bons resultados no ensino.

A terceira análise comparativa foi gerada a partir das informações dos diagramas sobre a integração das disciplinas especializadas com a prática em projeto, desenvolvidos para cada curso analisado e apresentados na Figura 23. A análise tem como objetivo classificar os cursos de acordo com os modelos paradigmáticos de currículo listados pelo EDUCATE na Seção 3.5 .

Logo, foram desenvolvidos gráficos tipo pizza para cada curso apresentando em percentual os vários tipos de integração das disciplinas especializadas com atividades de projeto ao longo do curso (nenhuma, parcial ou total), conforme visto na Figura 23. 


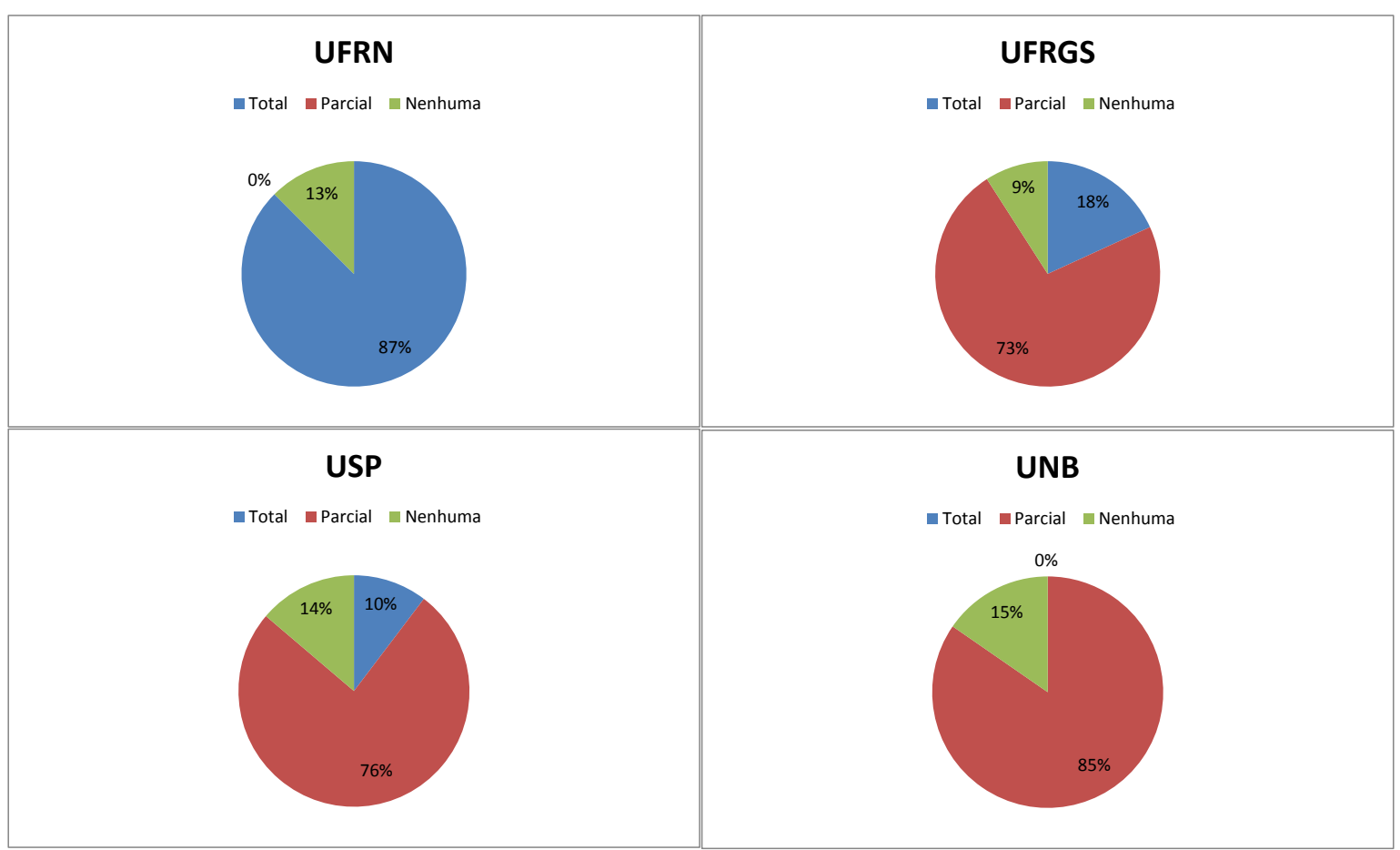

Figura 23: Nível de integração entre as disciplinas especializadas e projeto em ateliê, em

porcentagem de horas-aula

Apreende-se da Figura 23 que o curso da UFRN é o que apresenta a maior integração entre as disciplinas especializadas e atividades de projeto, estando $87 \%$ delas integradas totalmente com disciplinas de projeto. Este curso se caracteriza, principalmente, pela integração horizontal de grande parte das disciplinas em cada semestre do curso, além de possuir também a integração vertical, que corresponde ao aumento da complexidade dos temas ao longo do curso. Diante de tal constatação e de acordo com modelos definidos pelo EDUCATE, entende-se que o currículo em questão se classifica como modelo Totalmente Integrado.

O curso da UFRGS, por sua vez, apresentou que $18 \%$ das disciplinas especializadas estão totalmente integradas com ateliê de projetos e $73 \%$ estão parcialmente integradas. A integração dos conteúdos teóricos com a prática de projeto, no curso da UFRGS, se dá de forma independente em cada disciplina, ou seja, na maioria dos casos os alunos são convidados a desenvolver trabalhos práticos no domínio da própria disciplina especializada. Diante de tal constatação, entende-se que o currículo em questão se classifica como Parcialmente Integrado. 
O curso da USP apresentou, predominantemente, $76 \%$ das disciplinas especializadas com integração parcial com o projeto em ateliê e $10 \%$ com integração total. Da mesma forma, o curso da UnB apresenta também a predominância da integração parcial, com $85 \%$ das disciplinas nesta situação e nenhuma disciplina com integração total.

Em análise realizada pelo grupo EDUCATE, em 2011, o currículo da USP foi classificado como Linear/Paralelo. Contudo, naquela análise foram consideradas apenas as disciplinas de Conforto Ambiental do currículo (6 disciplinas). Nesta nova análise, consideraram-se oito disciplinas a mais do que a análise anterior (14 disciplinas), incluindo disciplinas de outras cadeias disciplinares voltadas à temática e disciplinas de projeto. Logo, concluiu-se que há integração com projeto em várias das disciplinas especializadas. Portanto, entende-se que os currículos da UFRGS, UnB e USP, a partir desta nova análise, se classificam como Parcialmente Integrados.

Logo, observa-se nos quatro cursos analisados que a maioria das disciplinas especializadas apresentou integração com a prática de projeto, seja ela de forma parcial ou total. Apenas 15\% ou menos das disciplinas especializadas destes cursos são aplicadas sem nenhuma integração com a prática de projeto.

Com relação ao período de inserção da temática da sustentabilidade no currículo dos cursos analisados, identificou-se que na USP e UnB as primeiras disciplinas que abordam a temática estão presentes desde o primeiro semestre, na UFRN desde o quarto semestre e na UFRGS desde o quinto semestre.

Outro aspecto que também pode ser comparado dentre os cursos utilizados, com possibilidade de impacto no ensino e aproveitamento do ensino da sustentabilidade, são os métodos de ensino e critérios de avaliação utilizados nas disciplinas especializadas e de projeto.

A Tabela 13 e o gráfico contido na Figura 24 a seguir apresentam os dados da recorrência dos métodos de ensino nas disciplinas especializadas dos cursos analisados, conforme respostas dos questionários enviados aos respectivos professores. 
Tabela 13: Recorrência de métodos de ensino nas disciplinas especializadas

\begin{tabular}{|l|r|r|r|r|}
\hline \multirow{2}{*}{$\begin{array}{l}\text { Método de ensino nas disciplinas } \\
\text { especializadas }\end{array}$} & \multicolumn{4}{|c|}{$\begin{array}{l}\text { Percentual de ocorrência do método de } \\
\text { ensino nas disciplinas especializadas }\end{array}$} \\
\cline { 2 - 5 } & UFRN & UFRGS & \multicolumn{1}{|c|}{ USP } & \multicolumn{1}{c|}{ UNB } \\
\hline Aulas teóricas & $100 \%$ & $100 \%$ & $100 \%$ & $100 \%$ \\
\hline Projeto & $50 \%$ & $100 \%$ & $71 \%$ & $43 \%$ \\
\hline Visitas de campo / levantamento de campo & $38 \%$ & $57 \%$ & $71 \%$ & $57 \%$ \\
\hline Exercícios & $50 \%$ & $71 \%$ & $57 \%$ & $29 \%$ \\
\hline Estudos de caso & $50 \%$ & $71 \%$ & $14 \%$ & $29 \%$ \\
\hline Pesquisa & $38 \%$ & $57 \%$ & $7 \%$ & $57 \%$ \\
\hline Seminários & $38 \%$ & $14 \%$ & $79 \%$ & $29 \%$ \\
\hline Debates & $38 \%$ & $71 \%$ & $14 \%$ & $29 \%$ \\
\hline Situação-problema & $38 \%$ & $29 \%$ & $29 \%$ & $29 \%$ \\
\hline Palestras de convidados & $38 \%$ & $43 \%$ & $29 \%$ & $0 \%$ \\
\hline Leitura & $25 \%$ & $29 \%$ & $7 \%$ & $43 \%$ \\
\hline Laboratório físico & $13 \%$ & $43 \%$ & $29 \%$ & $14 \%$ \\
\hline Laboratório virtual & $38 \%$ & $14 \%$ & $14 \%$ & $0 \%$ \\
\hline Painel de assessoramento & $0 \%$ & $57 \%$ & $0 \%$ & $0 \%$ \\
\hline
\end{tabular}

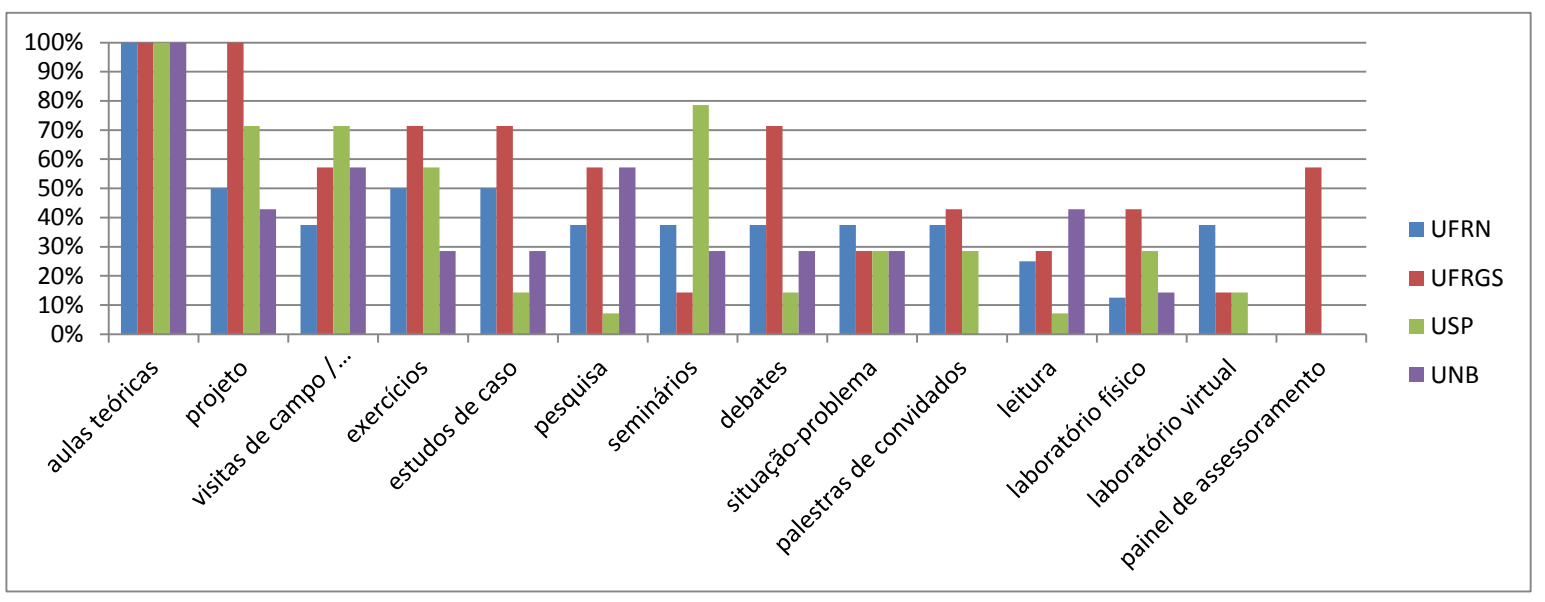

Figura 24: Recorrência de métodos de ensino nas disciplinas especializadas

Observa-se, na análise acima, que além das aulas teóricas (100\%), o projeto, visitas de campo, exercícios e estudos de caso, foram os métodos de ensino mais recorrentes nas disciplinas especializadas nos quatro cursos analisados.

Em contrapartida, o laboratório físico e o virtual foram alguns dos métodos menos utilizados. Contudo, na UFRGS o laboratório físico teve uma boa presença nas disciplinas especializadas (43\%) e o laboratório virtual na UFRN (38\%). 
Observa-se ainda que na USP utiliza-se mais o método de seminários do que os demais cursos (79\%). Na UFRGS, por sua vez, utiliza-se mais do método de projetos e do painel de assessoramento (apresentação das etapas do projeto para professores e colegas) em comparação com os demais cursos.

No que tange aos métodos utilizados nas disciplinas de projeto, observa-se o exposto na Tabela 14 e Figura 25 a seguir.

Tabela 14: Recorrência de métodos de ensino nas disciplinas de projeto

\begin{tabular}{|l|r|r|r|r|}
\hline \multirow{2}{*}{$\begin{array}{l}\text { Método de ensino nas disciplinas de } \\
\text { projeto }\end{array}$} & \multicolumn{4}{|c|}{$\begin{array}{r}\text { Percentual de ocorrência do método de } \\
\text { ensino nas disciplinas de projeto }\end{array}$} \\
\cline { 2 - 5 } & UFRN & UFRGS & \multicolumn{1}{c|}{ USP } & \multicolumn{1}{c|}{ UNB } \\
\hline Aulas teóricas & $100 \%$ & $100 \%$ & $100 \%$ & $100 \%$ \\
\hline Projeto & $100 \%$ & $100 \%$ & $100 \%$ & $100 \%$ \\
\hline Seminários & $31 \%$ & $29 \%$ & $100 \%$ & $77 \%$ \\
\hline Visitas de campo / levantamento de campo & $54 \%$ & $53 \%$ & $64 \%$ & $62 \%$ \\
\hline Exercícios & $38 \%$ & $59 \%$ & $36 \%$ & $38 \%$ \\
\hline Pesquisa & $31 \%$ & $47 \%$ & $36 \%$ & $46 \%$ \\
\hline Estudos de caso & $31 \%$ & $29 \%$ & $36 \%$ & $38 \%$ \\
\hline Palestras de convidados & $8 \%$ & $41 \%$ & $14 \%$ & $69 \%$ \\
\hline Leitura & $31 \%$ & $29 \%$ & $21 \%$ & $31 \%$ \\
\hline Debates & $23 \%$ & $12 \%$ & $36 \%$ & $31 \%$ \\
\hline Situação-problema & $31 \%$ & $18 \%$ & $21 \%$ & $8 \%$ \\
\hline Painel de assessoramento & $0 \%$ & $59 \%$ & $0 \%$ & $0 \%$ \\
\hline Laboratório físico & $8 \%$ & $0 \%$ & $21 \%$ & $23 \%$ \\
\hline Laboratório virtual & $0 \%$ & $0 \%$ & $7 \%$ & $15 \%$ \\
\hline APO & $8 \%$ & $0 \%$ & $0 \%$ & $0 \%$ \\
\hline
\end{tabular}

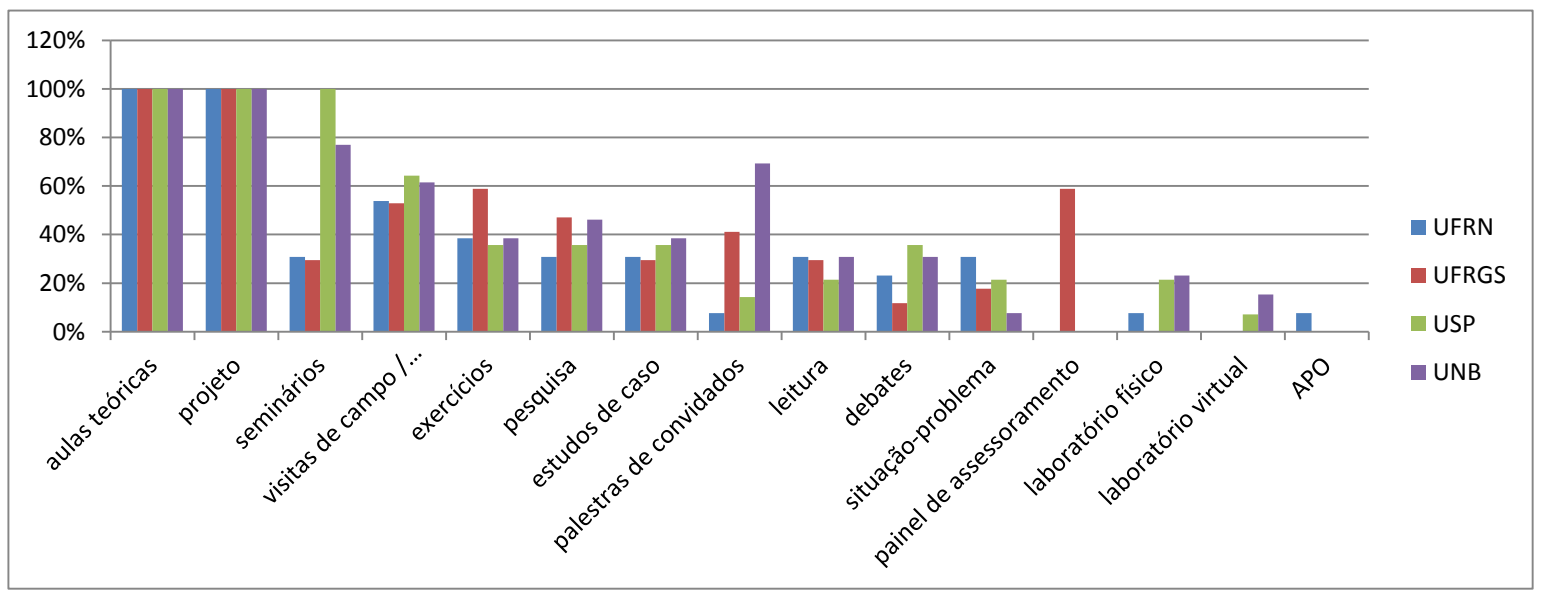

Figura 25: Recorrência de métodos de ensino nas disciplinas de projeto 
Observa-se, na análise acima, que os métodos de ensino mais utilizados nas disciplinas de projeto, além das aulas teóricas (100\%) são: seminários, visitas de campo e exercícios.Em contrapartida, assim como nas disciplinas especializadas, o laboratório físico e o virtual foram alguns dos métodos menos utilizados.

Destaca-se que na USP, nas disciplinas de projeto, também utiliza-se muito de seminários, em comparação com os demais cursos. Na UFRGS, por sua vez, destaca-se o uso do painel de assessoramento como método de ensino.

No que tange aos critérios de avaliação, a Tabela 15 e a Figura 26 a seguir demonstram as recorrências das principais técnicas conforme os dados dos questionários para as disciplinas especializadas.

Tabela 15: Recorrência de critérios de avaliação nas disciplinas especializadas

\begin{tabular}{|c|c|c|c|c|}
\hline \multirow[b]{2}{*}{ Critérios de avaliação nas disciplinas especializadas } & \multicolumn{4}{|c|}{$\begin{array}{l}\text { Percentual de ocorrência do } \\
\text { critério de avaliação nas } \\
\text { disciplinas especializadas }\end{array}$} \\
\hline & UFRN & UFRGS & USP & UNB \\
\hline Trabalho escrito/relatórios & $75 \%$ & $57 \%$ & $57 \%$ & $57 \%$ \\
\hline Exercícios & $75 \%$ & $57 \%$ & $43 \%$ & $57 \%$ \\
\hline Projeto desenvolvido (técnica/ criatividade) & $25 \%$ & $86 \%$ & $43 \%$ & $57 \%$ \\
\hline Prova (oral ou escrita) & $25 \%$ & $71 \%$ & $21 \%$ & $14 \%$ \\
\hline Representação/apresentação do projeto & $38 \%$ & $57 \%$ & $0 \%$ & $14 \%$ \\
\hline Participação/ evolução do aluno & $0 \%$ & $71 \%$ & $7 \%$ & $29 \%$ \\
\hline Apresentação de seminário & $38 \%$ & $14 \%$ & $43 \%$ & $0 \%$ \\
\hline Maquete & $13 \%$ & $0 \%$ & $0 \%$ & $29 \%$ \\
\hline $\begin{array}{l}\text { Apresentação das etapas do projeto para os demais colegas e } \\
\text { professores (painel de assessoramento) }\end{array}$ & $0 \%$ & $29 \%$ & $0 \%$ & $0 \%$ \\
\hline Outros & $0 \%$ & $0 \%$ & $7 \%$ & $0 \%$ \\
\hline
\end{tabular}

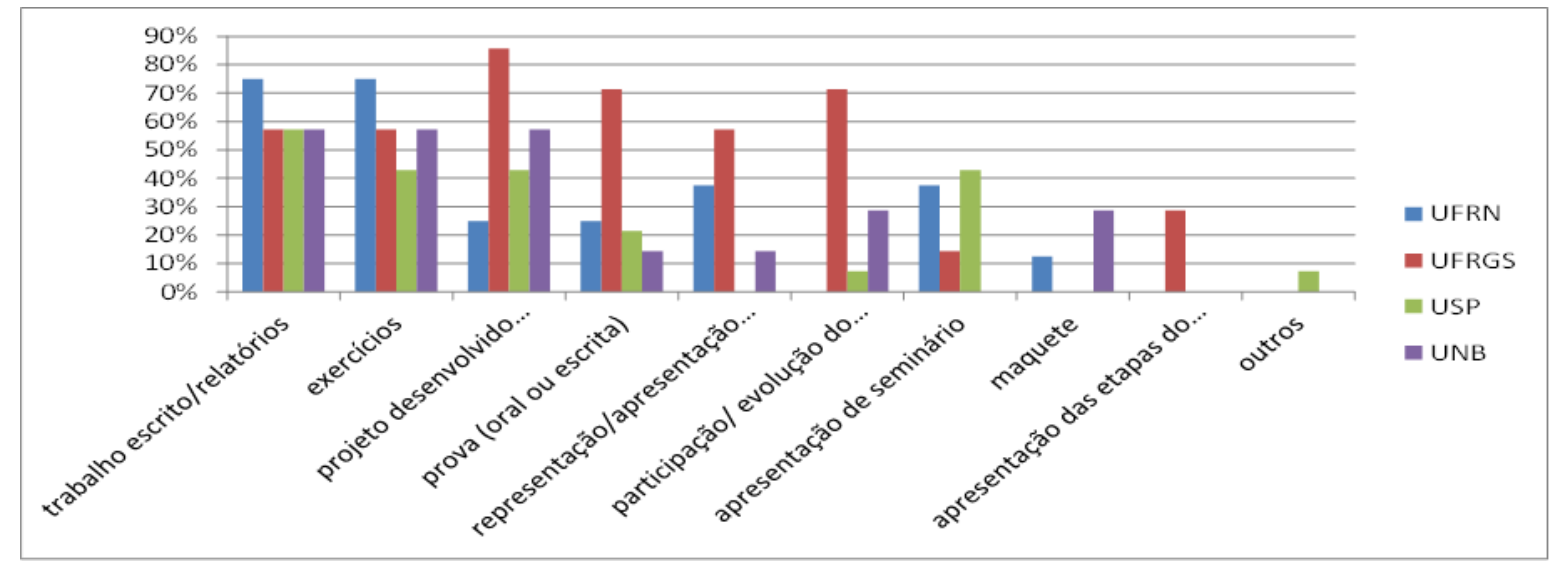

Figura 26: Recorrência de critérios de avaliação nas disciplinas especializadas 
Observa-se, na análise acima, que os critérios de avaliação mais utilizados nas disciplinas especializadas foram trabalho escrito/ relatórios, exercícios e projeto desenvolvido.

Em contrapartida, a maquete e o painel de assessoramento foram os critérios de avaliação menos utilizados.

Destaca-se que a UFRGS se diferencia pela grande utilização, como critério de avaliação, da prova (oral ou escrita) e da participação/ evolução do aluno, além do painel de assessoramento.

No que tange aos métodos utilizados nas disciplinas de projeto, observa-se a configuração exposta na Tabela 16 e Figura 27 a seguir.

Tabela 16: Recorrência de critérios de avaliação nas disciplinas de projeto

\begin{tabular}{|l|r|r|r|r|}
\hline \multirow{2}{*}{ Critérios de avaliação nas disciplinas de projeto } & \multicolumn{3}{|c|}{$\begin{array}{c}\text { Percentual de ocorrência do } \\
\text { critério de avaliação nas } \\
\text { disciplinas de projeto }\end{array}$} \\
\cline { 2 - 5 } & UFRN & UFRGS & \multicolumn{1}{|c|}{ USP } & UNB \\
\hline Projeto desenvolvido (técnica/ criatividade) & $31 \%$ & $82 \%$ & $93 \%$ & $69 \%$ \\
\hline Apresentação de seminário & $31 \%$ & $41 \%$ & $64 \%$ & $77 \%$ \\
\hline Participação/ evolução do aluno & $31 \%$ & $82 \%$ & $36 \%$ & $38 \%$ \\
\hline Representação/apresentação do projeto & $23 \%$ & $76 \%$ & $29 \%$ & $54 \%$ \\
\hline Maquete & $23 \%$ & $47 \%$ & $29 \%$ & $62 \%$ \\
\hline Exercícios & $38 \%$ & $29 \%$ & $43 \%$ & $46 \%$ \\
\hline Trabalho escrito/relatórios & $38 \%$ & $35 \%$ & $21 \%$ & $23 \%$ \\
\hline Apresentação das etapas do projeto para os demais colegas e & & & & \\
professores (painel de assessoramento) & $0 \%$ & $0 \%$ & $0 \%$ & $38 \%$ \\
\hline Prova (oral ou escrita) & $0 \%$ & $18 \%$ & $0 \%$ & $8 \%$ \\
\hline Outros & $0 \%$ & $0 \%$ & $0 \%$ & $0 \%$ \\
\hline
\end{tabular}




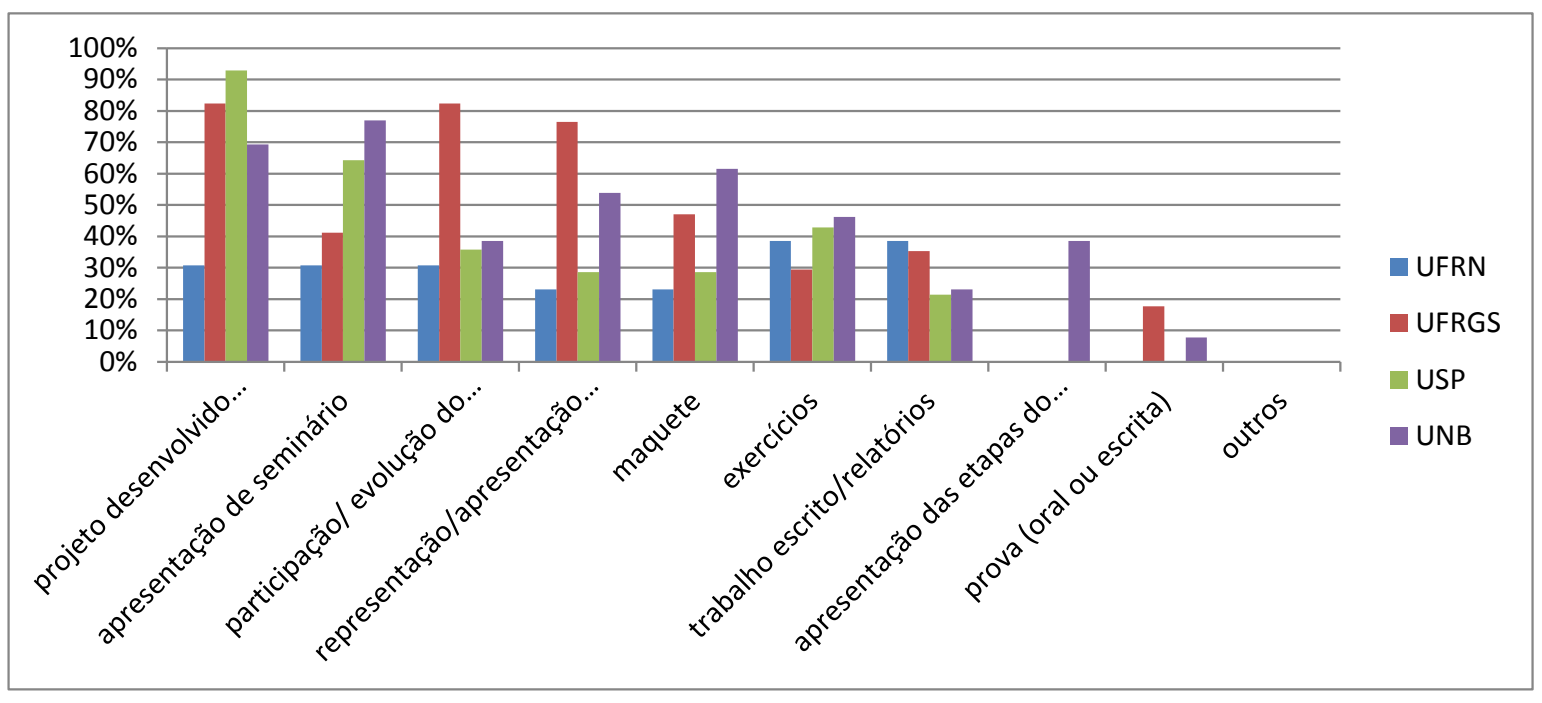

Figura 27: Recorrência de critérios de avaliação nas disciplinas de projeto

Observa-se, na análise acima, que os critérios de avaliação mais utilizados nas disciplinas de projeto foram projeto desenvolvido, apresentação de seminário e participação/ evolução do aluno.

Em contrapartida, o trabalho escrito/relatórios, a prova (oral ou escrita) e o painel de assessoramento foram os critérios de avaliação menos utilizados.

A UFRGS se diferencia pela grande utilização, como critério de avaliação, da participação/ evolução do aluno e do painel de assessoramento.

\subsection{DISCUSSÕES}

A primeira discussão refere-se à classificação dos cursos analisados de acordo com os modelos paradigmáticos estabelecidos pelo EDUCATE (2012 a), apresentados na Seção 3.5. A partir deles é prudente observar as orientações do grupo para o aprimoramento do ensino da sustentabilidade conforme o modelo do currículo, sendo que o foco pode ser diferenciado em cada ação conforme as carências dos currículos.

Nos cursos analisados nesta dissertação foi identificado que o currículo da UFRN se enquadra no modelo Totalmente Integrado e os demais cursos, UFRGS, USP E UnB se enquadram no modelo Parcialmente Integrado. 
Para ambos os casos, Totalmente Integrado e Parcialmente Integrado, as recomendações específicas para desenvolvimento dos currículos em nível de graduação são as constantes no Quadro 5 a seguir. Explicamos que, observando que as recomendações para aprimoramento dos currículos dos dois modelos encontrados são praticamente as mesmas, todas foram consolidadas em um mesmo corpo de texto e esclarecemos que as recomendações diferenciadas entre os dois modelos encontrados só seriam perceptíveis num estágio mais avançado do ensino (nível de doutorado).

Quadro 5: Propostas para aprimoramento dos currículos conforme o EDUCATE (2012a) adaptado

\begin{tabular}{|c|c|c|c|c|}
\hline $\begin{array}{c}\text { MODELO } \\
\text { PARADIGMÁTICO }\end{array}$ & \multicolumn{4}{|c|}{ RECOMENDAÇÕES PARA APRIMORAMENTO DOS CURRÍCULOS } \\
\hline 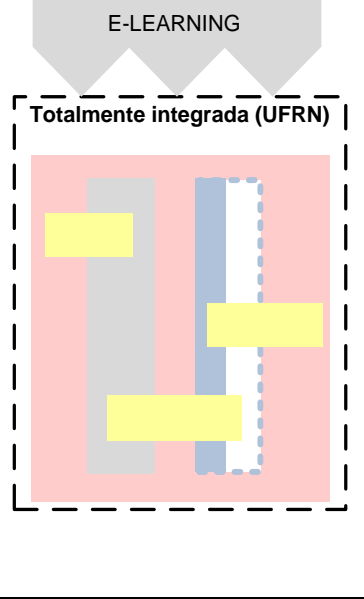 & \multicolumn{4}{|c|}{$\begin{array}{l}\text { Nestes dois modelos de currículo (Parcialmente Integrado e } \\
\text { Totalmente Integrado), como já há integração entre as disciplinas } \\
\text { teóricas com o projeto em ateliê, pode-se assumir que a aplicação dos } \\
\text { conceitos de sustentabilidade estão sendo trabalhados na prática. } \\
\text { Porém, é importante destacar que conteúdos trabalhados de forma } \\
\text { específica permitem também o aprofundamento da matéria devido à } \\
\text { dedicação e atenção exclusiva sobre o assunto, diferente da aplicação } \\
\text { em projeto onde o aluno está convivendo com diferentes variáveis e } \\
\text { focos diversos. A partir do momento em que o aluno aplica seus } \\
\text { conhecimentos e ao mesmo tempo consegue refletir e questionar o } \\
\text { tema em diferentes pontos de vista, pode-se se dizer que há uma visão } \\
\text { holística. } \\
\text { Considerando isto, a recomendação é que o foco de desenvolvimento } \\
\text { dos currículos seja a inserção de seminários e workshops com o } \\
\text { aprofundamento dos temas relacionados à sustentabilidade, onde } \\
\text { questionamentos poderiam ser levantados e novos tópicos } \\
\text { introduzidos, permitindo o desenvolvimento da abordagem holística } \\
\text { para a sustentabilidade e aumentando ainda mais a integração entre } \\
\text { as áreas. Certos seminários podem ser obrigatórios, enquanto outros, } \\
\text { optativos, para aprofundar mais o conhecimento junto à alunos com } \\
\text { interesse maior e habilidades na temática específica. } \\
\text { O uso de ferramentas de e-learning (ensino/acompanhamento à } \\
\text { distância) é recomendado com o objetivo de aumentar o acesso ao } \\
\text { conhecimento aprofundado sobre sustentabilidade ambiental conforme } \\
\text { a demanda e o tempo de cada aluno, facilitando a dissolução de } \\
\text { dúvidas e problemas durante os trabalhos práticos ou fora do ambiente } \\
\text { da Universidade. }\end{array}$} \\
\hline \multicolumn{5}{|c|}{ Legenda } \\
\hline Aielle & & Sustentabilidade ambiental & thecimentos & letivas \\
\hline
\end{tabular}

Conforme informado anteriormente as alterações curriculares propostas pelo EDUCATE estão sendo implementadas e monitoradas em várias universidades europeias e 
apontam resultados positivos, conforme descrito no relatório Results of Course and Curriculum Development (EDUCATE, 2012c). Logo, entende-se que é relevante considerar as recomendações do grupo em revisões de currículos brasileiros.

Outra discussão interessante envolve as análises dos quatro cursos com relação à carga horária voltada à temática da sustentabilidade apresentadas na Seção 5.2.5. Estas análises evidenciaram que existem diferentes formas de se abordar a temática da sustentabilidade nos cursos de Arquitetura e Urbanismo, tanto em disciplinas especializadas quanto em disciplinas de projetos ou outras de forma complementar a outras temáticas. Observando os currículos analisados nota-se que é significativamente maior a carga horária de todas as disciplinas que abordam a sustentabilidade (de forma direta ou indireta) se comparadas à carga horária apenas em disciplinas especializadas, conforme Figura 28.

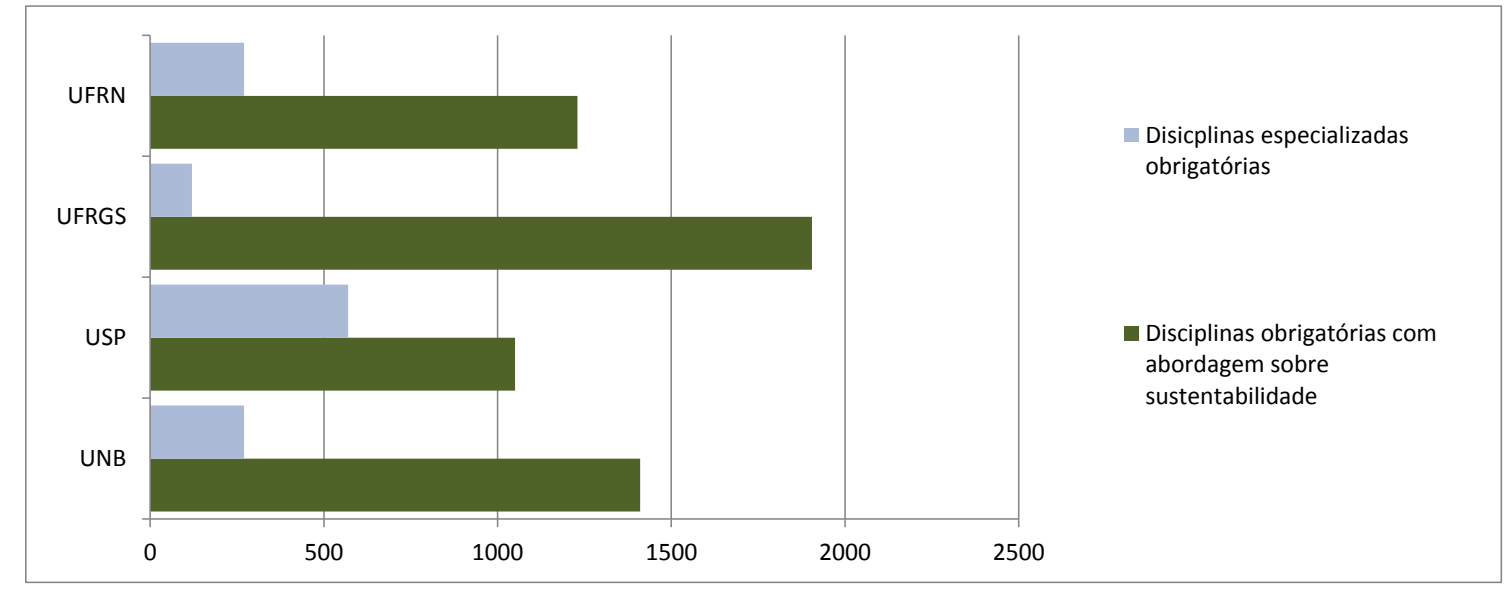

Figura 28: Carga horária das disciplinas especializadas obrigatórias x carga horária das disciplinas obrigatórias com abordagem sobre a sustentabilidade (de projeto e especializadas)

Além disso, a partir das demais análises constantes nesta dissertação de mestrado e considerando todas as disciplinas obrigatórias e também as eletivas que abordaram a sustentabilidade de forma direta ou indireta (ou seja a abordagem total da sustentabilidade no currículo) podemos identificar também que o currículo da UFRN possui a menor carga horária (1.380 h.a.) e a UFRGS a maior carga horária (2.250 h.a.). Contudo, a UFRN segue o modelo de currículo Totalmente Integrado, o que propicia a integração total entre os conhecimentos teóricos e a prática em ateliê. Já a UFRGS segue o modelo Parcialmente Integrado, possui a menor carga horária em disciplinas especializadas na temática, mas possui uma grande carga horária em outras disciplinas (incluído ateliê de projeto) que 
abordam a temática de forma complementar envolvendo a comunidade, clientes reais, dentre outros. Desta forma, percebe-se que a abordagem da temática em disciplinas não especializadas é uma outra forma de trabalhar a temática que também possibilita o alcance de bons resultados no ensino.

Também pudemos levantar, considerando ainda a abordagem total da sustentabilidade no currículo, que, com relação à carga horária total de cada curso, a UFRN abordou a temática em $41 \%$ das disciplinas do currículo, a UFRGS em 51\%, a USP em 32\%, e a UnB em 49\%. Logo, acredita-se que 30\% da carga horária total do curso de abordagem da temática de forma direta ou indireta, seja em disciplinas especializadas, de projeto ou outras, se apresentam como uma referência relevante já que os cursos apresentados alcançaram bons resultados no ensino.

Considerando as observações acima, podemos afirmar que a qualidade do ensino ofertado depende de uma série de fatores que se somam para produzir o resultado final e estes fatores possuem diversas variáveis inclusive dentro do próprio currículo. Na revisão bibliográfica e análises realizadas nesta dissertação de mestrado foi observado que os projetos político pedagógicos, currículos e planos de ensino podem influenciar nos resultados do ensino. Podemos constatar que os dois cursos que mais se destacaram nos eventos levantados (Bienais e "Enade-Sustentabilidade") - UFRN e UFRGS - possuem em seus currículos características bem diferentes, de maior e menor carga horária voltada ao tema, contudo, por suas metodologias diferenciadas ambos conseguiram alcançar resultados similares.

Com relação ao período de inserção da temática da sustentabilidade no currículo dos cursos analisados, o curso da UFRGS foi o que inseriu a temática mais tardiamente, no quinto semestre. Logo, entendemos que a inserção neste período acadêmico, que poderia ser considerada tardia por alguns autores, pode não ser a ideal, porém não foi tardia suficiente para prejudicar a qualidade do ensino ofertado, já que UFRGS foi selecionada como um dos cursos de destaque neste ensino.

Com relação à oferta de disciplinas especializadas eletivas, mensurando em carga horária, foi verificado que esta não foi inferior a $50 \%$ das disciplinas especializadas obrigatórias em nenhum dos cursos analisados. Logo, consideramos que esta seria uma boa referência já que os cursos analisados foram escolhidos pelos bons resultados alcançados. 
Também é relevante observar que nos quatro cursos analisados há integração da grande maioria das disciplinas especializadas com a prática de projeto, seja ela de forma parcial ou total. Apenas $15 \%$ ou menos das disciplinas especializadas destes cursos são aplicadas sem nenhuma integração com a prática de projeto.

Uma última discussão que deve ser levantada se refere ao crescimento da temática da sustentabilidade dentro dos currículos dos cursos de Arquitetura e Urbanismo nos últimos anos. No ano de 2006, Villela (2007) levantou por meio de pesquisa aplicada que ainda existiam arquitetos que não sabiam o significado do conceito de sustentabilidade. A autora aponta que grande maioria das pessoas pesquisadas disseram que achavam necessária alguma mudança no sistema de ensino de arquitetura, por considerar essencial a abordagem deste tema. Dentre os entrevistados, vários consideraram de grande importância que o tema fosse inserido na grade curricular em todas as disciplinas e não como uma disciplina isolada. Villela ainda relata que pouco mais da metade dos pesquisados afirmou que o tema sustentabilidade foi abordado em uma ou duas disciplinas e/ou palestras e seminários durante o ensino, e quase metade dos entrevistados respondeu que foi pouca ou superficial a abordagem da sustentabilidade na graduação.

Também, no início do desenvolvimento da presente dissertação, foi considerada a escolha do evento Ópera Prima como referência para a seleção dos cursos com os melhores resultados no ensino da sustentabilidade. Contudo, concluiu-se que não era possível avaliar a sustentabilidade por meio deste concurso, pois dos cinco projetos premiados, que tem suas pranchas em memoriais disponibilizados na página do evento, identificou-se que apenas dois tinham alguma relação com sustentabilidade, e mesmo assim, aspectos não muito relevantes. Logo, o concurso Ópera Prima, que é um concurso de grande repercussão e que avalia trabalhos finais de graduação, se apresenta como uma pequena amostra do ensino atual e transpareceu que a temática ainda está sendo pouco considerada.

Entende-se, contudo, que o retrato atual esteja diferente do evidenciado por Vilella, apesar de ainda estar distante do esperado. A revisão bibliográfica apresentada nesta dissertação demonstrou um crescimento da abordagem da sustentabilidade de forma mais clara e objetiva nos cursos de Arquitetura e Urbanismo nos últimos anos pois foram reescritas as diretrizes curriculares em 2010 enfatizando a importância da temática; foram publicados nacional e internacionalmente diagnósticos, trabalhos e regulamentos que deram maior destaque ao ensino da sustentabilidade na graduação em Arquitetura e 
Urbanismo (UNEP (2002 e 2010), EDUCATE (2011 - 2012), MPOG (2010 e 2014), MEC (2007 e 2010), SEDE (2012), UIA/UNESCO (1996); e as análises apresentadas na seção anterior também demonstraram os altos índices de abordagem da temática nos cursos analisados.

É claro que não podemos extrapolar as características curriculares dos cursos analisados e considerá-los estado da arte do ensino da sustentabilidade nos cursos de Arquitetura e Urbanismo no Brasil. Contudo, os cursos analisados apresentam boa abordagem do tema e pode-se perceber que as características curriculares identificadas são contributivas para a aprendizagem e podem ser utilizadas como subsídios para o desenvolvimento dos currículos de outas instituições.

De outra forma, se tomarmos como base, por exemplo, a avaliação do "Enadesustentabilidade" trabalhada nesta dissertação, temos uma amostra representativa do ensino do tema nos cursos do Brasil, assim como os respectivos desempenhos. A UFRN e a UFRGS apresentaram conceito 5 na avaliação, o que as coloca no seleto grupo de 9 (nove) cursos com desempenho semelhante. Porém, este grupo representa somente $6 \%$ do total de cursos validados (excluídos os que não possuem amostra representativa de alunos conforme o critério apresentado na Seção 4.1.3.1).

Conforme pode ser observado na Tabela 17 a seguir, apenas $40 \%$ dos cursos apresentam desempenho equivalente ao conceito 5 ou 4, enquanto os outros $60 \%$ apresentaram conceito 3 ou inferior (excluídos os 30 cursos que não tiveram amostra representativa de alunos na avaliação), o que indica que, no geral, ainda há muito o que se desenvolver nos cursos de arquitetura quanto ao ensino da sustentabilidade.

Tabela 17: Número de cursos por conceito no "Enade-Sustentabilidade"

\begin{tabular}{|c|c|c|}
$\begin{array}{c}\text { Conceito no ENADE- } \\
\text { Sustentabilidade }\end{array}$ & No de IES & \% acumulado \\
\hline $\mathbf{5}$ & 9 & $6 \%$ \\
\hline 4 & $\mathbf{5 2}$ & $40 \%$ \\
\hline $\mathbf{3}$ & $\mathbf{5 9}$ & $79 \%$ \\
\hline $\mathbf{2}$ & $\mathbf{3 0}$ & $99 \%$ \\
\hline $\mathbf{1}$ & 2 & $100 \%$ \\
\hline Total & 152 & \\
\hline
\end{tabular}


Com base na revisão bibliográfica e nas análises realizadas, de forma sistematizada, podemos apontar os seguintes caminhos que podem contribuir para a potencialização do ensino da sustentabilidade nos cursos de Arquitetura e Urbanismo no Brasil:

- Possibilitar a integração entre as disciplinas especializadas e atividades práticas de projeto (de forma parcial ou total);

- Destinar pelo menos $30 \%$ da carga horária total do curso a disciplinas que abordem a temática da sustentabilidade de forma direta ou indireta, ou seja, independendo que sejam disciplinas especializadas, de projeto ou outras;

- Ofertar disciplinas especializadas eletivas para possibilitar uma maior especialização na temática aos interessados, preferencialmente $50 \%$ ou mais de carga horária extra com relação às disciplinas especializadas obrigatórias;

- Abordar o tema de forma contínua ao longo de todo o curso, a fim de demonstrar que pensar a sustentabilidade é inerente ao projeto de arquitetura devendo acontecer de forma simultânea e, preferencialmente, desde o início do curso.

É importante destacar que nas análises desta dissertação de mestrado não existiu a intenção de criticar qualquer curso, pelo contrário, apontar os potenciais e diferenciais dos mesmos para que sejam modelos para cursos em elaboração ou etapa de revisão, diferenciais estes, que só foram possíveis a identificação através das análises e comparações. 


\section{CONSIDERAÇÕES FINAIS}

O presente capítulo apresenta as principais conclusões e as considerações finais do trabalho, incluindo, limitações para o desenvolvimento do mesmo e sugestões para trabalhos futuros. Destaca-se que a presente dissertação buscou aprofundar em discussões referentes ao ensino da sustentabilidade nos cursos de Arquitetura e Urbanismo com ênfase na dimensão ambiental.

Através de revisão bibliográfica, levantamentos, análises e discussões expostas ao longo do texto apresentamos subsídios para auxiliar na elaboração e revisão de currículos e também colaboramos com a pesquisa sobre o ensino. Logo, contribuímos indiretamente com a promoção da sustentabilidade na Arquitetura e Urbanismo visto que a formação do arquiteto é determinante para a sua atuação profissional seja no âmbito do projeto arquitetônico e urbanístico; arquitetura paisagística; patrimônio histórico, cultural e artístico; planejamento urbano e regional; da topografia; da tecnologia; dos sistemas construtivos e estruturais; de instalações e equipamentos; do conforto ambiental; do meio ambiente; e do estudo e avaliação dos impactos ambientais; pois as diretrizes e conceitos da sustentabilidade na arquitetura aplicam-se a qualquer das práticas.

Uma das constatações desta dissertação foi que a investigação da melhor forma de ensinar a sustentabilidade nos cursos de Arquitetura e Urbanismo é uma preocupação de alcance internacional, conforme apresentado no capítulo 1 que evidencia a necessidade atual de aprimoramento deste ensino. Neste contexto, a revisão dos currículos de graduação para o aprimoramento do ensino no Brasil e no mundo é um tema que está em foco. O fato é comprovado quando observamos as diferentes recomendações de organismos nacionais e internacionais neste sentido, como UNEP (2002 e 2010), EDUCATE (2011 - 2012), MPOG (2010 e 2014), BRASIL-Governo Federal (2010), MEC (2007 e 2010), SEDE (2012), UIA/UNESCO (1996). Assim quando encontramos relatos e documentos de alguns anos atrás que evidenciam preocupação com a carência de tratar o tema nos currículos e comparamos com as análises realizadas nesta dissertação de mestrado fica demonstrado que os cursos vêm buscando diferentes formas de adaptar seus currículos e estruturas de ensino a esta realidade.

As legislações nacionais, apesar de estarem acontecendo de forma mais tardia com relação a países mais desenvolvidos, são um reforço na promoção da mudança do cenário 
da construção civil nacional, por meio de incentivos, capacitação e regulamentação estimulam a estruturação para uma nova forma de atuação dos arquitetos, mais voltada para ações no âmbito da sustentabilidade. Conforme apresentado no capítulo 2, verifica-se já a algum tempo que essa mudança de legislação voltada à atuação profissional vem gerando reflexos tanto na graduação quanto na pós-graduação, incluindo a atualização de profissionais já em pleno exercício.

Apesar de evidenciada e declarada a preocupação sobre a inclusão da sustentabilidade no conteúdo dos cursos de Arquitetura e Urbanismo por parte dos organismos nacionais e internacionais, não existe legislação voltada ao ensino que oriente de forma clara como deve se dar a abordagem da temática nos projetos pedagógicos e currículos dos cursos. Desta forma, ficou constatado que o ensino da sustentabilidade nos cursos de Arquitetura e Urbanismo no Brasil ainda não possui um perfil delineado. Este ensino é permeado por uma heterogeneidade de práticas pedagógicas com aprofundamentos em diferentes enfoques e proporções que se baseiam, sobretudo, no perfil dos professores e da escola cursada.

De fato, compreende-se em parte a postura do MEC de não detalhar demasiadamente os caminhos para a formatação dos currículos com relação à temática da sustentabilidade, pois não há um consenso entre os educadores para tal, além do quê, isto poderia engessar a criatividade e inovações em currículos brasileiros. Por outro lado, podem ser apresentadas recomendações gerais adaptáveis e aplicáveis em diferentes intensidades conforme especificidades de cada currículo, conforme subsídios identificados nesta dissertação de mestrado e apresentados ao final do capítulo 5:

- Possibilitar a integração entre as disciplinas especializadas e atividades práticas de projeto (de forma parcial ou total);

- Destinar pelo menos $30 \%$ da carga horária total do curso a disciplinas que abordem a temática da sustentabilidade de forma direta ou indireta, ou seja, independendo que sejam disciplinas especializadas, de projeto ou outras;

- Ofertar disciplinas especializadas eletivas para possibilitar uma maior especialização na temática aos interessados, preferencialmente $50 \%$ ou mais de carga horária extra com relação às disciplinas especializadas obrigatórias; 
- Abordar o tema de forma contínua ao longo de todo o curso, a fím de demonstrar que pensar a sustentabilidade é inerente ao projeto de arquitetura devendo acontecer de forma simultânea e, preferencialmente, desde o início do curso.

Com relação à integração entre disciplinas especializadas e atividades práticas de projeto, os quatro cursos analisados foram classificados de acordo com os modelos paradigmáticos identificados pelo EDUCATE. O currículo da UFRN se classifica no modelo Totalmente Integrado e os demais cursos, UFRGS, USP E UnB se classificam no modelo Parcialmente Integrado, conforme Figura 23.

Considerando as análises e revisão bibliográfica realizadas, acredita-se que os cursos nacionais que se encontram em constante atualização e revisão de currículos e projetos político pedagógicos, em sua maioria, devem se enquadrar no modelo Parcialmente Integrado, já que existe hoje uma tendência de reformular o ensino pensando nas várias possibilidades de integração entre teoria e prática de projeto, isto inclui não só a temática da sustentabilidade. Já o caso da UFRN aparenta ser uma excepcionalidade no contexto dos cursos nacionais, pois não foi identificada em bibliografia situação similar no país que tenha planejado uma integração curricular tão intensa, aparentando ser uma experiência pioneira no âmbito nacional. Acredita-se que os demais cursos do país, aqueles que pouco têm revisto seus currículos e projetos político pedagógicos, tenham permanecido com perfil mais próximo do Linear/Paralelo, já que a dificuldade de integração entre teoria e prática é uma deficiência que já vinha sendo identificada em bibliografia de longa data e, aparentemente, uma característica da maioria dos cursos nacionais.

Por meio da classificação dos quatro currículos analisados nos modelos paradigmáticos identificados pelo EDUCATE foi possível observar as orientações específicas do grupo para o aprimoramento do ensino que atendem de forma mais direcionada às especificidades de cada modelo paradigmático. Ou seja, com relação aos modelos Parcialmente Integrado e Totalmente Integrado, a orientação do EDUCATE, considerando que já foi identificada a integração entre teoria e prática, consiste principalmente em:

- Intensificar o aprofundamento dos conteúdos específicos, para o maior aprofundamento na matéria e suas especificidades; 
- Inserção de seminários e workshops na grade curricular, obrigatórios e eletivos, para dirimir dúvidas e possibilitar maior integração entre áreas de conhecimento;

- Implementar o uso de ferramentas e-learning (ensino/acompanhamento à distância), para ampliar o acesso aos conteúdos específicos conforme a demanda e tempo adequados e facilitando o acesso fora do ambiente da Universidade.

Desta forma, considerando os resultados encontrados além da revisão bibliográfica, conclui-se que a integração entre a teoria e a prática (esteja ela no domínio da disciplina ou envolvendo disciplinas distintas); a carga horária dedicada aos conteúdos (seja ela em disciplinas especializadas no tema ou em disciplinas já existentes que também abordam a temática); a oferta de disciplinas eletivas voltadas ao tema; e a presença da temática ao longo de todo curso e desde seu início, são alguns dos fatores identificados nesta dissertação que influenciam na qualidade do ensino ofertado.

Em outras palavras, é prudente concluir que não há um caminho único ou forma padronizada de abordar a sustentabilidade no ensino da Arquitetura e Urbanismo, mas há experiências de cursos brasileiros e do exterior apresentadas e discutidas nesta dissertação de mestrado que podem servir de subsídio para o ensino. Entende-se também que os quatro cursos analisados servem de referência no ensino da temática no Brasil e, por isso, podem servir de parâmetro, nos quesitos analisados, para cursos em formação ou reformulação do projeto político pedagógico, currículos e planos de ensino.

Destaca-se ainda que a decisão deste trabalho de ampliar a análise da abordagem da sustentabilidade das disciplinas especializadas para as demais disciplinas, inclusive de projeto (aprimorando o método do EDUCATE) foi providencial para algumas constatações, pois ficou demonstrado que a UFRGS, por exemplo, alcança resultado de destaque no ensino com pouca carga horária de disciplinas especializadas e estabelecendo, predominantemente, integração parcial com a prática de projeto. Isso se explica pelo fato de possuir uma grande carga horária em outras disciplinas (incluído ateliê de projeto) que abordam a temática de forma complementar, envolvendo a comunidade, clientes reais, o método do painel de assessoramento, dentre outros. Desta forma, conclui-se que a abordagem da temática em disciplinas não especializadas é também muito relevante para os bons resultados alcançados no ensino. 
Por fim, as razões que influenciam os resultados da aprendizagem da sustentabilidade na arquitetura podem ser inúmeras. Não foi intenção do presente trabalho inferir que somente o modelo de currículo ou a forma de abordagem do tema seriam fatores determinantes para os resultados, mas sim, explorar as potencialidades que os ajustes nestes elementos podem corroborar para o alcance deste objetivo. Logo, não podemos deixar de apontar que inúmeras variáveis podem interferir no aprendizado, inclusive em maior intensidade e independente da estrutura curricular, tais como:

- A preparação/qualificação do corpo docente;

- As especialidades do corpo docente e das Coordenações dos cursos, que podem nortear rumos para o ensino em determinadas vertentes em detrimento de outras;

- A presença de laboratórios e outros espaços de trabalho prático complementares que podem estimular a visão holística do estudante sobre a sustentabilidade;

- O próprio edifício e campi da Universidade, que tal como apontado na $\mathrm{s}$ revisões bibliográficas, servem de instrumento modelo de aprendizado constante ao estudante;

- Os trabalhos de pesquisa e desenvolvimento durante o curso, assim como projetos de iniciação científica que abordam o tema;

- A forma e padrão de ingresso da universidade, que pode modelar o perfil desejável do estudante para os objetivos da instituição;

- Os interesses individuais de cada aluno, que podem ser estimulados de diferentes formas ao longo do curso, conforme a área de atuação desejável e conciliar com os interesses da instituição;

- As tendências apontadas pelo mercado de trabalho e a atuação profissional que chegam ao ambiente da universidade; 
- A existência e a qualidade de cursos de pós-graduação nas próprias instituições com linhas de pesquisa sobre o tema, o que pode aproximar mais o estudante da graduação ao assunto e estimular a continuidade do estudo;

- Aspectos regionais de onde o curso está instalado, pois os cuidados da sociedade com os recursos naturais, por exemplo, podem influenciar consideravelmente no papel da instituição e, consequentemente, no seu ensino; $\mathrm{e}$

- Toda a bagagem prévia dos estudantes sobre a sustentabilidade proveniente de aspectos culturais e educacionais. Daí, a importância de se trabalhar o tema desde a educação fundamental, tal como orienta as diretrizes curriculares do MEC.

Logo, as variáveis apresentadas acima também podem levar a diferenciais nos resultados do ensino que subsidiem o aprimoramento do mesmo em cursos de Arquitetura e Urbanismo.

Por fim, conclui-se que o trabalho em questão alcançou os objetivos propostos e fornece subsídios para orientar discussões, trabalhos e estudos referentes ao ensino da sustentabilidade nos cursos de Arquitetura e Urbanismo.

\subsection{LIMITAÇÕES DA PESQUISA}

No início do desenvolvimento da presente dissertação, foi considerada a escolha do evento Ópera Prima como referência para a seleção dos cursos com os melhores resultados no ensino da sustentabilidade. Contudo, concluiu-se que não era possível avaliar a sustentabilidade por meio deste concurso, pois dos cinco projetos premiados, que tem suas pranchas em memoriais disponibilizados na página do evento, identificou-se que apenas dois deles tinham alguma relação com sustentabilidade, e mesmo assim, aspectos não muito relevantes.

Durante a etapa de levantamento de dados, uma das dificuldades encontradas foi encontrar os documentos necessários e também o recebimento dos dados de forma mais detalhada, para facilitar a tabulação dos mesmos. A falta de padronização dos termos 
usados em cada projeto político pedagógico dos cursos e a variedade na forma de organização dos mesmos, separação por áreas, contabilização de créditos, dentre outros, agregou muita complexidade às informações. Contudo, as informações coletadas foram destrinchadas tanto quanto possível e, infelizmente, análises mais precisas do que as apresentadas não puderam ser desenvolvidas.

Destacamos que as respostas aos questionários que foram enviados para os quatro cursos analisados tiveram um retorno razoável de 69\%- UFRN, 50\%- UFRGS, 62\%- USP e 75\%- UnB, com relação aos questionários voltados a disciplinas obrigatórias. Com relação às disciplinas eletivas o retorno foi muito baixo, destaca-se que variou entre $10 \%$ e $20 \%$, o que se deve à dificuldade de encontrar documentação sobre as mesmas e à maior instabilidade curricular destas disciplinas.

Com relação a incoerências encontradas nos dados coletados, destaca-se que algumas ementas disponibilizadas nos sites das universidades apresentaram incompatibilidades com relação aos questionários respondidos pelos professores. Nestes casos, conforme previamente definido no método, considerou-se válida a informação coletada em questionário. Com relação a incoerências específicas, destaca-se que, mesmo coletando os dados em sites oficiais, a UFRN e a UnB apresentaram divergências entre a carga horária mínima informada de forma objetiva e a carga horária mínima obtida a partir do somatório das disciplinas listadas nos currículos. Tal incompatibilidade foi atribuída à deficiência de algumas ementas ou a alterações curriculares que não foram devidamente registradas. Logo, tentou-se identificar essas inconsistências dentre as disciplinas de interesse analisadas, contudo, as incompatibilidades não foram identificadas. Logo, entende-se que, provavelmente, estas divergências se direcionam a outras áreas disciplinares. De todo modo, ressalta-se que essas incoerências são de pequena escala e não teriam peso de alterar as principais características identificadas nos currículos.

A maior limitação da pesquisa, contudo, consistiu na não obtenção das informações necessárias para realizar as análises do curso de Arquitetura e Urbanismo da UFU, um dos cinco cursos selecionados. Desde o início do levantamento de dados houve muita dificuldade de encontrar material sobre o curso disponibilizado na internet, verificados o site oficial e também outras possíveis fontes de informação. Posteriormente, insistindo na possibilidade de análise do mesmo, contatou-se via telefone a coordenação do curso. Contudo, era tão grande a demanda de informações quanto a dificuldade da secretaria do 
curso em repassá-las, pois, entendeu-se que as informações necessárias à análise não estavam disponíveis em meio digital e os funcionários não tinham condição de produzi-las para envio. Por fim, ao percebermos esta dificuldade, já não havia tempo hábil para iniciar a análise de outro curso.

Diante das limitações apresentadas, nota-se a importância de que os cursos mantenham seus projetos político pedagógicos, currículos e planos de ensino atualizados e com fácil disponibilidade, como solicita o Ministério da Educação. Também seria inmportante uma padronização na disponibilização dos dados dos cursos, seguindo uma mesma nomenclatura e tabelas com as mesmas informações, ou seja, que o MEC fornecesse os modelos para disponibilização das informações essenciais. Desta forma, as propostas para reformulação do ensino poderiam ser mais precisas e bem embasadas em números, mais análises do ensino ofertado poderiam ser desenvolvidas, em menor tempo, e teríamos um retrato do ensino ofertado no país mais preciso e constantemente atualizado.

\subsection{SUGESTÕES PARA TRABALHOS FUTUROS}

Entende-se que um dos pontos chave das análises realizadas neste trabalho foi a utilização da rica fonte de dados que é o Enade, com levantamento quase total do ensino ofertado no país. O Enade representa um ótimo recurso para análise de diversos aspectos do ensino no Brasil, no caso desta dissertação de mestrado exploramos o ensino da sustentabilidade, contudo, outros aspectos do ensino podem ser extraídos dos dados coletados no exame.

Neste sentido, é importante deixar como sugestões para trabalhos futuros que outros cursos também sejam avaliados. O método adotado na presente dissertação para a seleção dos cursos com destaque no ensino da sustentabilidade, neste trabalho intitulado "EnadeSustentabilidade", pode ser o balizador para coleta dados de novos cursos. Ou seja, seguindo o mesmo método de análise, podem ser realizadas comparações das análises já realizadas com as novas; podem ser realizadas comparações no perfil do ensino ao longo dos anos, passados e vindouros; e pode-se realizar análise dos cursos que não se destacaram no ensino da sustentabilidade para possibilitar a comparação e identificação das maiores deficiências e possíveis fontes de divergências na qualidade do ensino ofertado. 
Fica também a sugestão, para análises futuras, de analisar o curso da Universidade Federal de Uberlândia - UFU, que conforme demonstrado, foi selecionado para análise pelo seu destaque no ensino do tema, porém não conseguimos os dados necessários para análise. Além disso, cabe a análise do desempenho dos alunos na aplicação dos conhecimentos teóricos em prática em projetos por meio do concurso Ópera Prima ou outro, o que não foi possível realizar neste trabalho.

Destaca-se também que a classificação dos quatro currículos analisados nos modelos paradigmáticos identificados pelo EDUCATE e os dados levantados sobre o ensino em cada curso podem ser utilizados na ampliação do banco de dados do grupo EDUCATE que já possui um amplo levantamento do ensino da sustentabilidade em cursos de vários países, principalmente da Europa. Desta forma, pretende-se organizar as análises desenvolvidas e demais dados levantados sobre o ensino e encaminhá-los para apreciação do grupo e possível disponibilização dos dados em site de ampla divulgação voltado à área da sustentabilidade, contribuindo com a continuidade do trabalho iniciado pelo EDUCATE.

Complementamos também que as demais variáveis do ensino citadas neste capítulo também poderiam embasar trabalhos futuros nesta linha de pesquisa, podendo resultar em subsídios complementares para aprimoramento do ensino da sustentabilidade na Arquitetura e Urbanismo no Brasil. 


\section{REFERÊNCIAS BIBLIOGRÁFICAS}

AIA and NACo. Local Leaders in Sustainability Green Building Incentive Trends. The American Institute of Architects (AIA) e National Association of Counties (NACo), 2012;

AMORIM, Cláudia; CINTRA, Jônio; LIMA, Paulo Castilho; BRENDOLAN, Renata; CLÍMACO, Rosana Stockler Campos, LIMA, Thais Borges Sanches. Projeto Ambiental Integrado: Os Desafios do Ensino de Arquitetura. XII ENTAC, 2008;

ANDRADE, Liza Maria Sousa de; LIRA, Flaviana; RIBAS, Otto Toledo; SANT`ANA, Daniel; SILVA, Caio Frederico; MEDEIROS, José Marcelo. Método de Ensino para projetos de urbanismo mais sustentáveis: resultado da integração horizontal das disciplinas de projeto de urbanismo, paisagismo, infraestrutura e conforto térmico da FAUUnB. Brasília: XII ENCAC e VIII ENLACAC, 2013;

ANTAC - Associação Nacional de Tecnologia do Ambiente Construído. Bienal Sustentável José Lutzenberger (Disponível em: http://www.antac.org.br/grupos/desenvolvimento-sustentavel - acesso em 03/09/12) 2012;

ARAÚJO, V.M.D; DANTAS, E.M.; ARAÚJO, J.B. O Ensino Integrado de Conforto Ambiental no Curso de Arquitetura e Urbanismo da UFRN: Relato de experiências. ENCAC, 1999;

ASSOCIAÇÃO BRASILEIRA DE NORMAS TÉCNICAS- ABNT. NBR 15.575: Desempenho de Edificações Habitacionais - Atividades técnicas. Rio de Janeiro, 2013;

AVEZUM, André Luís. Arquitetura ecológica e tecnologia no século XX: base para o projeto arquitetônico sustentável. Dissertação (Mestrado de Arquitetura e Urbanismo) Universidade de São Paulo- USP. São Paulo: 2007;

BAFFI, Maria Adelia Teixeira. Projeto Pedagógico: um estudo introdutório. Pedagogia em Foco.Petrópolis: 2002. Disponível em: <http://www.pedagogiaemfoco.pro.br/gppp03.htm>. Acesso em: 01/11/2012;

BEATRICE, Claudionor. O Ensino de projeto de arquitetura face à ética ambientalista. (Disponível em: www.pucpr.br/eventos/educere/educere2006/anaisEvento/docs/CI-305-TC.pdf. Acesso em 31/07/12) PUCPR: VI EDUCERE, 2006;

BIENAL, Miguel Aroztegui. Concurso Estudantil Latino-Americano de Arquitetura Bioclimática (Disponível em: http://www.arq.ufsc.br/bienal/vibienal.aspx - acesso em: agosto 2012), 1999;

Associação Nacional de Tecnologia do Ambiente Construído - ANTAC

(Disponível em: http://www.antac.org.br/grupos/conforto-ambiental-e-eficienciaenergetica - acesso em: agosto 2012), 2011; 
BISSOLI, M. Recomendações para a sustentabilidade da habitação de interesse social: uma abordagem ao Conjunto Residencial Barreiros, Vitória (ES). Dissertação (Mestrado em Engenharia Civil) - Programa de Pós Graduação em Engenharia Civil, Universidade Federal do Espírito Santo. Vitória: 2007;

BLUMENSCHEIN, Raquel Naves. A Sustentabilidade na Cadeia Produtiva da Indústria da Construção. Tese ( Doutorado) Universidade de Brasília- Centro de Desenvolvimento Sustentável. Brasília: 2004;

BRASIL. Ministério de Minas e Energia. Plano Nacional de Eficiência Energética (Disponível em: http://www.mme.gov.br/mme/galerias/arquivos/noticias/2010/PNEf__Premissas_e_Dir._Basicas.pdf. acesso em: maio de 2011). Brasília: 2010 a;

Instituto Nacional de Metrologia, Normalização e Qualidade Industrial (INMETRO). Requisitos Técnicos da Qualidade para o Nível de Eficiência Energética de Edifícios Comerciais, de Serviços e Públicos. Portaria $\mathrm{n}^{\circ} 372$. (Disponível em: www.inmetro.gov.br/legislacao/rtac/pdf/RTAC001599.pdf. acesso em: mar. 2011) Rio de Janeiro: 2010 b;

Instituto Nacional de Metrologia, Normalização e Qualidade Industrial (INMETRO). Regulamento Técnico da Qualidade para o Nível de Eficiência Energética de Edificações Residenciais. Portaria $\mathrm{n}^{\circ} 449$. (Disponível em: http://www.inmetro.gov.br/legislacao/rtac/pdf/RTAC001627.pdf- acesso em março de 2011) Rio de Janeiro: 2010 c;

BRASIL. LEI No. 10.295. Dispõe sobre a Política Nacional de Conservação de Energia. 17 out 2001 ;

BRASIL. LEI No. 12.378. Regulamenta o exercício da profissão de arquiteto e urbanista. $31 \mathrm{dez} 2010$;

BRUNDTLAND, Gro Harlem. Our common future: The World Commission on Environment and Development. Oxford: Oxford University, 1987;

CEOTTO, L. H. A sustentabilidade como valor estratégico para a Tishman Speyer. In: Encontro Internacional de Sustentabilidade na Construção, org. Centro de Tecnologia de Edificações.São Paulo: 2008;

CESAR, Deborah Adriana Tonini Martini. O uso dos questionários online como apoio para as pesquisas acadêmicas discentes no Ensino Superior. 2012;

CIB/UNEP. Agenda 21 for Sustainable Construction in Developing Countries - First discussion document.The International Council for Research and Innovationin Building and Construction , 2002;

CORBELLA, O. D.; YANNAS, S. Em busca de uma arquitetura sustentável para os trópicos: conforto ambiental. Rio de Janeiro: Revan, 2003; 
DEGANI, Clarice Menezes; CARDOSO, Francisco Ferreira. A sustentabilidade ao longo do ciclo de vida do edifício: a importância do projeto arquitetônico. In: NUTAU 2002 (Disponível em: www.docentes.pcc.usp.br/cardoso/nutau -acesso em: 26/ago/ 2006), 2002;

DERNBACH, J. C.; TYRRELL, M. Federal Energy Efficiency and Conservation Laws. Law of clean energy: efficiency and renewables. Widener Law School Legal Studies Research, Paper No. 10-30, 2010;

DOURADO, Brenda Milhomem; AMORIM, Cláudia Naves David. O ensino da sustentabilidade em cursos de Arquitetura e Urbanismo no Brasil. In: XII Encontro Nacional de Conforto no Ambiente Construído- ENCAC. Brasília: 2013;

DUARTE, Denise Helena Silva; Mülfarth, Roberta Kronka; GONÇALVES, Joana Carla Soares. Sustentabilidade Ambiental Urbana no Ensino de Graduaçao: Proposta do Departamento de Tecnologia da FAUUSP. In: IX Encontro Nacional e V Latino Americano de Conforto no Ambiente Construído- ENCAC ,2007;

DUMKE, E. M. S. A Avaliação do desempenho térmico em sistemas construtivos da vila tecnológica de Curitiba como subsídio para a escolha de tecnologias apropriadas em habitação de interesse social. Dissertação de mestrado em Tecnologia, Centro Federal de Educação Tecnológica do Paraná. Curitiba, 2002;

DUSI, Raul Luís de Melo. Estudo sobre Programas de Educação Ambiental no Brasil e a Questão da Sustentabilidade Ambiental. Tese (Doutorado em Ecologia) Universidade de Brasília. Brasília:2006;

EDUCATE - :Environmental Design in University Curricula and Architectural Training in Europe. Framework for Curriculum Development (Disponível em: <www.educatesustainability.eu> acesso em 03/07/2012), 2011;

Criteria for Professional Qualification - White Paper. (Disponível em: <www.educate-sustainability.eu> acesso em 03/07/2012), 2012 a;

Results Summary - Education for Sustainable Environmental. (Disponível em: <www.educate-sustainability.eu> acesso em 03/07/2012), 2012 b;

Results of Course and Curriculum Development. (Disponível em: <www.educate-sustainability.eu> acesso em 03/07/2012), 2012 c;

State of the Art Academic Curricula. (Disponível em: <www.educatesustainability.eu> acesso em 03/07/2012), 2012 d;

EDWARDS, Brian. Guia básico para a sustentabilidade. Barcelona: Gustavo Gili, 2008;

ELECS - Encontro Latino-americano sobre Edificações e Comunidades Sustentáveis Bienal José Lutzenberger 2011 (Disponível em: http://www.elecs2011.com.br/portugues/bienal_elecs2011.pdf - acesso em : 03/09/12), 2011; 
EUROPEAN COMMISSION. Site (Disponível em : http://ec.europa.eu/energy/en/topics/energy-efficiency/energy-efficiency-directive - acesso $\underline{05 / 01 / 15}), 2015$

FARIA, Rodrigo dos Santos. O ensino da Arquitetura e do Urbanismo na FAU-UnB: uma (contínua) construção pela diversidade de olhares. Brasília, 2010;

FAU. Estrutura Curricular da FAU-USP 2012 (Disponível em: http://www.fau.usp.br/cursos/graduacao/arq_urbanismo - acesso em: 20/11/12), 2012;

Plano de ensino das disciplinas da FAU-USP (Disponível em: https://uspdigital.usp.br/jupiterweb/obterDisciplina - acesso em: 01/12/12), 2011;

Projeto Político Pedagógico da FAU-USP, 2010;

FERREIRA, Aurélio Buarque de Holanda. Dicionário Aurélio Básico da Língua Portuguesa. J.E.M.M. Editores; 1988;

FILHO, R. L. L. S.; MOTUJENAS, P. R.; HIPÓLITO, O.; LOBO, M. B. C. M. (2007). A evasão no ensino superior brasileiro. Instituto Lobo para o Desenvolvimento da Educação, da Ciência e da Tecnologia. Cadernos de Pesquisa, v. 37, n. 132, set./dez. 2007;

FLORENÇANO, José Carlos Simões; ABUD, Maria José Milharezi. Histórico das Profissões de Engenheiro, Arquiteto e Agrônomo no Brasil. Revista Ciências Exatas, vol. 5-8. Taubaté: 2002;

FOSTER, Norman. Architecture and Sustainability. (Disponível em: www.fosterandpartners.com/content/essays/Architecture\%20and\%20Sustainability.pdf acesso em: 20/ 07/12), 2003;

GONÇALVES, Joana Carla Soares; DUARTE, Denise Helena Silva. Arquitetura Sustentável : uma integração entre ambiente, projeto e tecnologia em experiências de pesquisa, prática e ensino.In: Ambiente Construído, Porto Alegre, v. 6, n. 4, p. 51-81 out./dez. 2006;

INEP- Instituto Nacional de Estudos e Pesquisas Educacionais Anísio Teixeira. Microdados Enade Arquitetura 2011- (Disponível em: http://portal.inep.gov.br/basicalevantamentos-microdados2011- acesso em 30/08/2012), 2011;

Enade 2011- Seminário parte 1. (Disponível em: http://portal.inep.gov.br/seminarios-Enade - acesso em 30/08/2012 ), 2011a;

. Manual Enade 2011 (Disponível em: http://portal.inep.gov.br/manual-doEnade - acesso em 30/08/2012 ), 2011b;

http://portal.inep.gov.br), 2013

Censo da Educação Superior - 2007 (Disponível em: 
INMETRO. Site (Disponível em: http://www2.inmetro.gov.br/pbe/historico.php - acesso em 01/12/2014) 2014;

INTERNACIONAL LIVING BUILDING INSTITUTE. Living Building Challenge 2.0. (Disponível em: www.ilbi.org - acesso em 30/ 10 /12,), 2010;

KEELER, Marian; BURKE, Bill. Fundamentos de Projeto de Edificações sustentáveis. Tradução Alexandre Salvaterra. Porto Alegre: Bookman , 2009;

KOWALTOVSKI, D.C.C.K; CELANI, M.G.C; MOREIRA, D.C.; PINA, S.A.M.G.; RUSCHEL.R.C; SILVA, V.G.; LABAKI, L.C.; PETRECHE, J.R.D. Reflexão sobre metodologias de projeto arquitetônico. Revista Ambiente Construído, vol.6, n. ${ }^{\circ}$ 2, 2006;

LAMBERTS, R.; TRIANA, M. A.; FOSSATI M.; BATISTA, J. O. Sustentabilidade nas Edificações: contexto internacional e algumas referências brasileiras na área. Florianópolis: Universidade Federal de Santa Catarina (UFSC), 2008;

LARA, Fernando. Entrevista. Revista aU, (Disponível em:www.revistaau.com.br/arquitetura-urbanismo/174/fato-opniao-a-arquitetura-estariamelhor-sem-as-escolas-101158-1.asp - acesso em: 08/08/12), 2008;

LEITE, C. Ensino de arquitetura: O Brasil perdeu o rumo? Revista aU, 13 (Disponível em: www.revistaau.com.br/arquitetura- urbanismo/203/conversas-latino-americanascharlas- latinoamericanas-ensino-de-arquitetura-o-brasil-208856-1.asp - acesso em: 08 /08/ 2012) Ed.203, março de 2011;

LIDDLE, H.; HALLIDAY, S. How an ethical dimension can transform design in practice. Inproceedings The 2005 World SustainableBuilding Conference, 2005;

LIMA, Licínio C. ; AZEVEDO, Mário Luiz N. de ; CATANI, Afrânio M. O Processo de Bolonha: A avaliação da educação superior e algumas considerações sobre a Universidade Nova. ( Disponível em: http://ape.unesp.br/pdi/execucao/artigos/avaliacao /a02v13n1.pdf) . Sorocaba: 2008;

LOVELOCK, James E. Gaia: A new look at life on Earth. Oxford : Oxford University Press, 1979;

MAZRIA, Edward. It's the Architecture, Stupid! - Who really holds the key to the global thermostat? The answer might surprise you. Solar Today, May/June, 2003;

MCCORMICK, John. Rumo ao Paraíso: a história do movimento ambientalista tradução de Marco Antônio Esteves da Rocha e Renato Aguiar. Rio de Janeiro: RelumeDurnarã, 1992;

MCKEOWN R. Education for Sustainable Development Toolkit. Version 2. Energy, Environment and Resources Center University of Tennessee, 2002;

MEC. Portaria no 1.770. Brasília: 21 de dezembro de 1994. Ministério da Educação,1994; 
.Resolução no 6, de 02 de fevereiro de 2002, do Ministério da Educação, 2006;

.Resolução no 2, de 17 de junho de 2010, do Ministério da Educação,2010;

.Resolução no 2, de 18 de junho de 2007, do Ministério da Educação,2007;

MPOG - Ministério do Planejamento, Orçamento e Gestão. Instrução Normativa No 01/10 - para a sustentabilidade de obras públicas. Brasília: 19 de janeiro de 2010;

MPOG - Ministério do Planejamento, Orçamento e Gestão. Instrução Normativa $\mathbf{N}^{\mathbf{0}}$ 02/14 - para Eficiência Energética. Brasília: 04 de junho de 2014;

NETO, J. M. R. Tecnologia do Ambiente Construído e Sustentabilidade - Plano de Ensino. Faculdades Integradas da UPIS. Brasília, DF, 2010;

ÓPERA PRIMA. Concurso de Trabalhos Finais de Graduação em Arquitetura e Urbanismo. (Disponível em: http://pt.scribd.com/doc/94973420/Regulamento-OperaPrima-2011 - acesso em 10/08/2012), 2011;

PASEVI, Alessandra; FREITAS, Denise de. A problemática socioambiental na formação do arquiteto: perspectivas e desafios apontados por um estudo do currículo de um curso de Arquitetura e Urbanismo. São Paulo, RISCO 7 -Revista de pesquisa em Arquitetura e Urbanismo- EESC USP, 2008;

PEREIRA, Bruno Capanema. Inserção de critérios de sustentabilidade à fase de concepção de projetos arquitetônicos: subsídios para uma ferramenta. Dissertação de Mestrado, UnB, 2010;

PERRONE, Rafael Antônio Cunha; VARGAS, Heliana Comin. Fundamentos de Projeto: Arquitetura e Urbanismo. São Paulo: Editora da Universidade de São Paulo, 2014;

PROCEL. Site. (Disponível em: wwweletrobras.com/procel - acesso em 01/08/2012), 2012;

ROWE, D. Education for a Sustainable Future. Science. vol 317. PolicyForum. (Disponível em: <www.sciencemag.org> acesso em 25/08/2012), 2007;

SACHS, Ignacy. Estratégias de transição para o século XXI: desenvolvimento e meio ambiente. São Paulo: Ed. Nobel, 1993;

SATTLER, Miguel Aloysio. Ecoconstruções. In: BUSTOS ROMERO, Marta Adriana (org.). Reabilitação Ambiental Sustentável Arquitetônica e Urbanística. Brasília: FAU/UnB, 2009;

SEDE - Sustainable Environmental Design Education. Site. (Disponível em: < www.calpoly.edu/ sede/home.html> acesso em 25/08/ 2012) 2012;

SEGAWA, Hugo. Clave de Sol: notas sobre a história do conforto ambiental. Revista Ambiente Construído -ANTAC, 2003; 
SCHWARTZMAN, Simon. Funções e Metodologias de avaliação do Ensino Superior. Documento de trabalho do Núcleo de Pesquisas sobre Ensino Superior (NUPES), 1989;

SILVA, Vanessa Gomes da; SILVA, Maristela Gomes da; AGOPYAN, Vahan. Avaliação do Desempenho Ambiental de Edifícios : Estágio Atual e Perspectivas para Desenvolvimento no Brasil. Revista Ambiente Costruído, 2003;

SOBREIRA, Fabiano. Concursos de arquitetura e sustentabilidade: entre a retórica e a prática - o enfoque ambiental nos concursos realizados no Brasil e no Canadá entre 2000 e 2007. (Disponível em:http://fabianosobreira.files.wordpress.com/2009/07/concursos-esustentabilidade-fabianosobreira-projetar2009.pdf - acesso em 15/06/12) , 2008;

. Arquitetura e Sustentabilidade : os riscos da onda verde - reflexões sobre a

retórica ambiental nos concursos de arquitetura. (Disponível em: http://fabianosobreira.files. wordpress.com/2009/07/arquitetura-os-riscos-da-onda-verdefabianosobreira-19cba-recife.pdf - acesso em 15/06/12) , 2009;

STOCCO, Josete Alzira Passamani. Projeto Político Pedagógico: Conscientização ou Imposição? Dissertação de Mestrado .Passo Fundo: UPF, 2005;

SUSTAINABLE ENERGY ASSOCIATES. Site. (Disponível em: http://www.sustainableenergyassc.com. (2010) -acesso em 05/01/2015), 2015;

TRIOLA, Mário F. Introdução à Estatística. $7^{\text {a }}$ edição. Rio de Janeiro: LTC, 1999;

UFRN. Projeto Pedagógico da Faculdade de Arquitetura e Urbanismo da Universidade Federal do Rio Grande do Norte. FAU/UFRN, 2005;

Site.

(Disponível

em:

www.sigaa.ufrn.br/sigaa/link/public/curso/curriculo/510278490, acesso em: 05/01/2013), 2013;

UFRS. Site. (Disponível em: www.ufrgs.br/comgrad-arq, acesso em: 05/01/2013) , 2013;

UIA/UNESCO. Charter for Architectural Education. U.I.A. WORK PROGRAMME 'EDUCATION' / UNESCO. (Disponível em: www.unesco.org/most/uiachart.htm - acesso em 22/08/2012), 1996;

UnB. Site. (Disponível em: www.unb.br/fau - acesso em:12/06/2013) , 2013;

UNCED - Conferência das Nações Unidas para o Meio Ambiente e o Desenvolvimento. Agenda 21. 1992;

UNEP- United Nations Environment Program. Guidelines on Education Policy for Sustainable Built Environments. (Disponível em: http://www.unep.org/resourceefficiency/Publications/Publication/tabid/444/language/enUS/Default.aspx?BookID=4182, acesso em: 22/08/12), 2010; 
USP. Projeto Pedagógico da Faculdade de Arquitetura e Urbanismo da Universidade de São Paulo. PPP- FAU/USP, 2010;

Site. (Disponível em: www.fau.usp.br/cursos/graduacao/arq_urbanismo, acesso em: 25/03/2013), 2013;

VASCONCELOS, Ricardo L; PIRRÓ, Lúcia ; NUDEL, Marcelo. A importância da inserção dos conceitos de sustentabilidade no currículo das Escolas de Arquitetura no Brasil para a formação das novas gerações de arquitetos.In:ENTAC (XI Encontro Nacional de Tecnologia do Ambiente Construído), 2006;

VELOSO, Maisa. Entrevista. Revista aU, Ed.174 de setembro (Disponível em: www.au.pini.com.br/arquitetura-urbanismo/174/artigo101158-1.aspx), 2008;

VIANNA, Nelson Solano. Análise Crítica do Ensino de Conforto Ambiental nas Escolas de Arquitetura. In: ENCAC 2001. VI Encontro Nacional de Conforto no Ambiente Construído e III Encontro Latino-Americano de Conforto no Ambiente Construído. São Pedro - SP: 2001;

VILLELA, Dianna Santiago. A sustentabilidade na formação atual do arquiteto e urbanista. Dissertação de mestrado. UFMG, 2007;

WINES, James. Green architecture. Köln: Benedikt Taschen Verlag GmbH, 2000;

XAVIER, Sílvia Pedroso. A temática da sustentabilidade no ensino de graduação em Arquitetura e Urbanismo: estudo de caso das experiências de três instituições públicas. Curitiba: Dissertação de Mestrado, UFPR ,2011;

WACKERNAGEL, M; Rees, W. Our Ecological Footprint: Reducing Human Impact on the Earth. Philadelphia, PA: New SocietyPublishers, 1996.

WWF. Relatório Planeta Vivo 2010: biodiversidade, biocapacidade e desenvolvimento. 2010 ;

ZANIN, Nauíra Zanardo; CRUZ, Júlio Henrique Pinto. A sustentabilidade no ensino de arquitetura na Faculdade de Arquitetura/ UFRGS. Encontro Latino-Americano de sobre Edificações e Comunidades Sustentáveis-ELECS. Recife, 2009. 
ANEXOS 
ANEXO 1: QUESTÕES SELECIONADAS DA PROVA DE ARQUITETURA- ENADE 2011 QUE ABORDARAM A SUSTENTABILIDADE COM OS RESPECTIVOS GABARITOS E PADRÃO DE RESPOSTA (INEP, 2011).

Questões objetivas: 15, 17, 19, 23 e 32

Questões discursivas: 3,4 e 5

QUESTÕES OBJETIVAS:

ENUNCIADOS E GABARITO DAS QUESTÕES OBJETIVAS DE MÚLTIPLA ESCOLHA

QUESTÃO 15- B

\section{QUESTÃO 15}

Uma das vantagens do uso de sistemas informatizados no processo de projeto em arquitetura é a possibilidade de simulação, com vistas à avaliação do desempenho das edificações. Uma simulação que procure avaliar uma edificação em termos de desempenho térmico deverá levar em conta, entre outros fatores, a delimitação de zonas térmicas, o padrão de ocupação, os materiais de vedação e revestimento, a orientação solar das fachadas e o sistema de ar-condicionado utilizado.

Nesse contexto, avalie as afirmações a seguir.

I. Os ambientes de uso distinto não podem ser agrupados na mesma zona térmica, mesmo com ganhos térmicos equivalentes.

II. O peso dado a cada um dos fatores independe das necessidades de avaliação.

III. Na delimitação das zonas térmicas, os limites não precisam ser necessariamente físicos.

IV. O nivel de detalhamento da modelagem tridimensional para avaliação do desempenho térmico é o mesmo para a avaliação da iluminação natural.

É correto apenas o que se afirma em
A 1.
B III.
C I e II.
D II e IV.
E III e IV.

\section{QUESTÃO 17- B}




\section{QUESTÃO 17}

Uma vertiginosa dinâmica é inerente à própria natureza das atividades desenvolvidas no edifício hospitalar. Grandes mudanças na área médica e o avanço tecnológico, seja nas técnicas terapêuticas seja na própria construção do edifício hospitalar e na sua manutenção, têm pressionado mudanças na forma de conceber hospitais. Eles devem ser capazes de ser cada vez mais rapidamente adaptados e adaptáveis, tanto no que diz respeito à alteração de uso, à introdução de novas instalações e equipamentos, quanto a mudanças espaciais seja de adaptação ou de expansão.

BRASIL. Ministério da Saúde. Secretaria de Assistência à Saúde. Série Saúde e Tecnologia (Textos de Apoio à Programação Física de Estabelecimentos Assistenciais de Saúde) Sistemas Construtivos na Programação Arquitetônica de Edifícios de Saúde. Brasília, 1995, p.31 (com adaptações).

Considerando as características das edificações hospitalares apresentadas no texto, avalie as afirmações a seguir.

I. Os edifícios hospitalares compactos facilitam as modificações construtivas e funcionais ao longo do tempo.

II. A padronização estrutural e construtiva de edifícios hospitalares facilita a adaptação desses edifícios a novas funções.

III. O lançamento estrutural de um edifício hospitalar deve obedecer a organização espacial proposta pelo primeiro programa funcional.

IV. A autonomia da estrutura, da vedação e das instalações, nos edifícios hospitalares, facilita a incorporação de avanços tecnológicos da área médica.

É correto apenas o que se afirma em

A le ll.

B II e IV.

C III e IV.

D I, II e III.

E I, III e IV.

\section{QUESTÃO 19- E}




\section{QUESTÃO 19}

A figura a seguir ilustra um estudo preliminar de parcelamento do solo urbano idealizado para uma cidade localizada abaixo do Trópico de Capricórnio (zona temperada sul).

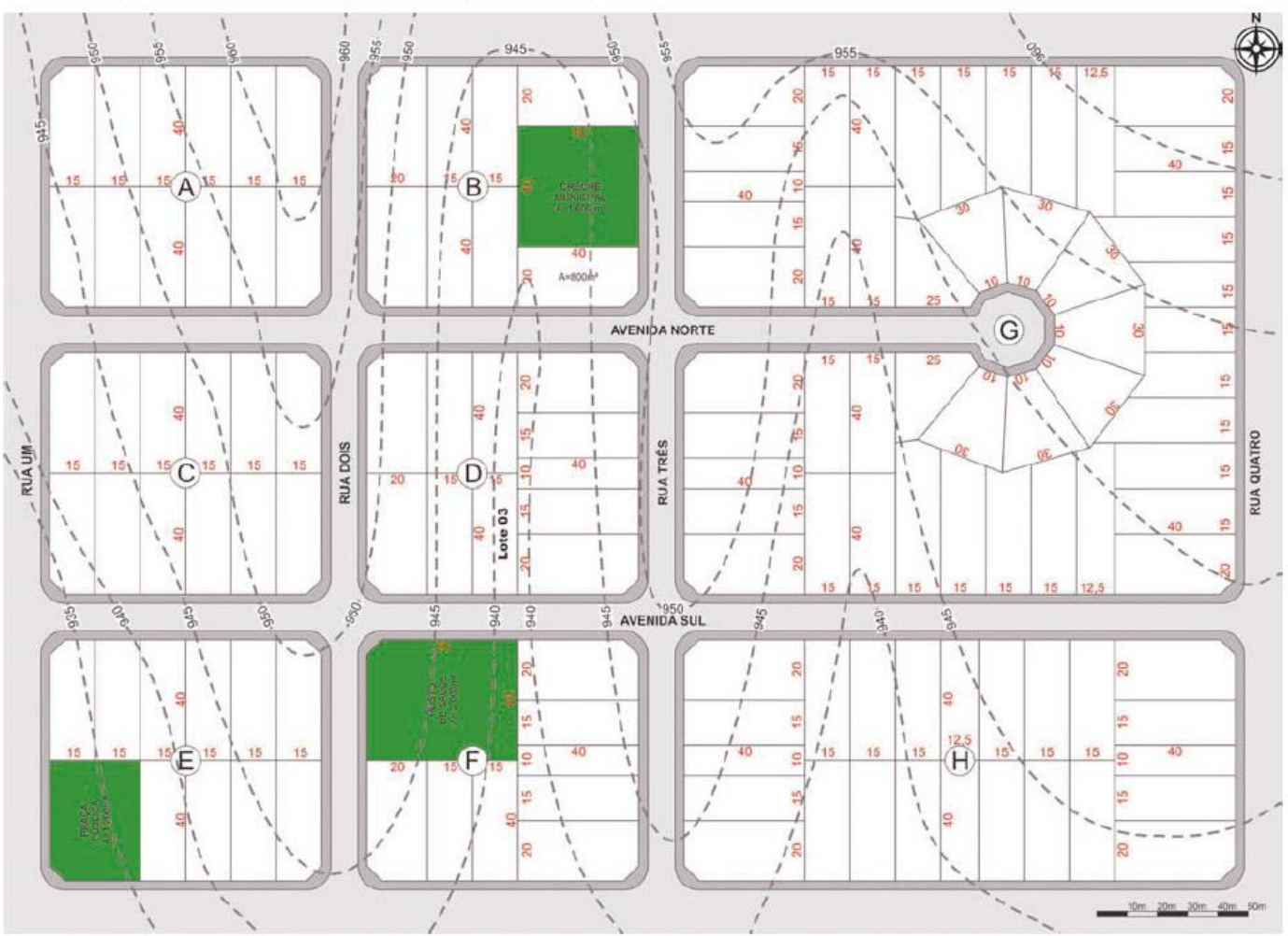

Com base na figura apresentada, avalie as afirmações que se seguem.

I. A quadra $G$ apresenta menor custo por hectare para o empreendedor, pois sua configuração reduz os gastos com os sistemas de infraestrutura.

II. A sobreposição das linhas de água com o sistema viário e o traçado ortogonal permite concluir que a retícula urbana resultante do projeto respeita a topografia do local.

III. A utilização de árvores de médio porte com raízes pivotantes nas faces norte e oeste das quadras e a implantação dos postes de iluminação nas faces sul e leste geram maior conforto para o pedestre durante o verão e menor conflito entre as infraestruturas.

IV. A lei n. ${ }^{\circ} 6766 / 79$ de parcelamento do solo após alterações impostas pela Lei $n .{ }^{\circ} 9785 / 99$ prevê que as áreas destinadas a sistemas de circulação, a implantação de equipamento urbano e comunitário, bem como a espaços livres de uso público, serão proporcionais à densidade de ocupação prevista.

É correto apenas o que se afirma em

A I ell.

B II e IV.

C III e IV.

D I, II e III.

E I, III e IV.

\section{QUESTÃO 23- E}




\section{QUESTÃO 23}

$\mathrm{Na}$ concepção do bioclimatismo aplicado ao desenho urbano, para cada região, existem princípios referentes à localização de um assentamento, ao tipo de traçado urbano e à morfologia do local (forma, vias, lotes e tamanho dos espaços construídos), que propiciam conforto térmico ambiental. Esses princípios são determinados em função

A da altitude do local.

B do sombreamento natural.

C das declividades existentes.

D da natureza dos materiais de revestimento.

E da orientação e direção dos ventos dominantes.

\section{QUESTÃO 32- B}




\section{QUESTÃO 32}

A cidade de Seul tem um rio chamado Cheoggyecheon, que havia se transformado em um esgoto, foi coberto por concreto nos anos 50 . O trecho recebeu uma via elevada de seis pistas e ali passou a circular um trânsito intenso. Hoje, o rio corre limpo e a céu aberto, cercado por um parque. O que aconteceu para tornar isso possível foi um grande projeto de demolição das autopistas e criação do parque, que dá passagem novamente ao leito natural do rio com suas águas já tratadas.
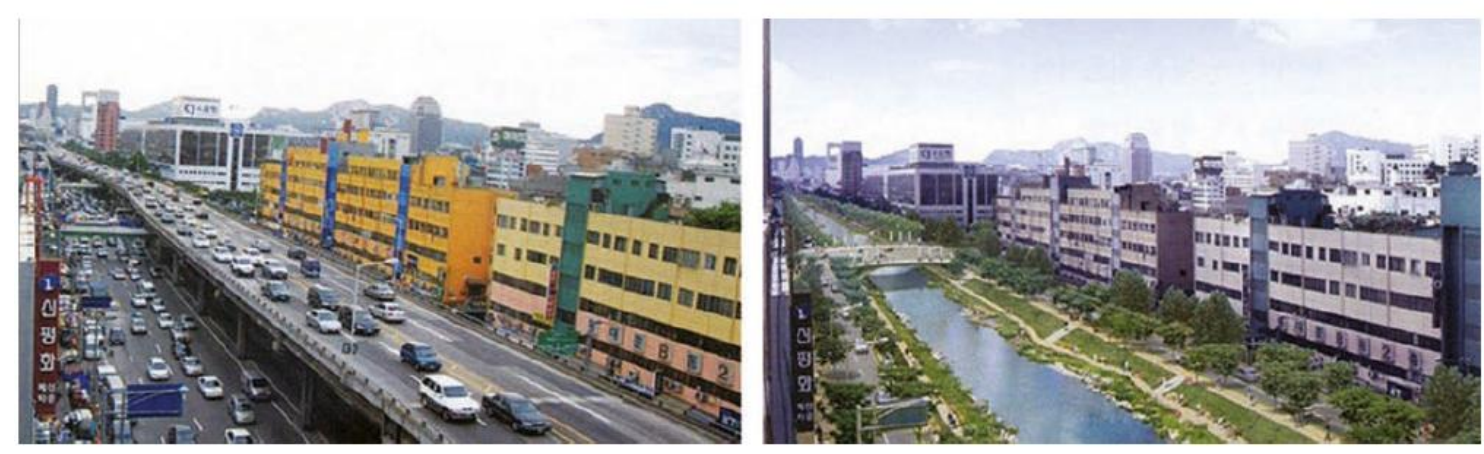

Disponivel em: <http://www.arquitetonico.ufsc.br/uma-impressionante-renovacao-urbana-em-seul> Acesso em: 30 set. 2011.

A partir do texto e das imagens apresentadas e considerando que os rios desempenham um importante papel na dinâmica urbana, avalie as afirmações a seguir.

I. A criação de vias expressas sobre rios possibilita uma maior mobilidade na cidade e maior integração viária com o entorno da via.

II. A presença de parques lineares nas margens de rios pode alterar o microclima local reduzindo a temperatura média ao redor do parque, se comparada com o restante da cidade.

III. Lagos artificiais criados em parques podem ser utilizados como bacias de detenção, que tem o objetivo de absorver o excedente de águas no período de pico das chuvas, escoando-as lentamente após o seu término.

IV. A retificação e canalização dos rios em áreas urbanas é o mecanismo mais eficiente para o combate às cheias, pois possibilita que a água escoe mais rapidamente da área com problemas de enchentes a um baixo custo.

É correto apenas o que se afirma em
A I e IV.
B II e III.
C III e IV.
(D) I, II e III.

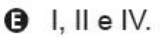

\section{QUESTÕES DISCURSIVAS:}

\section{QUESTÃO DISCURSIVA 3}


As estratégias de megaeventos esportivos da atualidade estão fortemente associadas a um desenvolvimento urbano com base no consumo, sendo esse orientado mais diretamente para diferentes formas de lazer, turismo, esporte e entretenimento. A cidade é então modelada para atender à demanda por serviços e equipamentos que possam servir como reprodutores das atividades que atraem distintas camadas de consumidores urbanos.

Disponivel em: <observatoriogeograficoamericalatina.org.mx>. Acesso em: 4 set. 2011.

Os megaeventos colocam processos importantes em movimento, envolvendo recursos significativos. Nesse sentido, trazem riscos e oportunidades para as cidades e países que os sediam. (...) É fundamental aproveitar a realização dos megaeventos evitando que tenham impactos negativos do ponto de vista ecológico e social, e, ao contrário, resultem em benefícios significativos, melhorando as condições de vida da população local.

Disponivel em: <www.riodetransportes.org.br>. Acesso em: 4 set. 2011.

Tendo as informações acima como referência inicial e considerando que algumas cidades brasileiras sediarão os eventos da Copa do Mundo de Futebol de 2014, redija um texto dissertativo que aborde, necessariamente, os seguintes aspectos:

a) impacto ambiental, positivo e negativo, gerado pelos megaeventos esportivos; (valor: 5,0 pontos)

b) impacto social, positivo e negativo, gerado pelos megaeventos esportivos. (valor: 5,0 pontos)

\section{PADRÃO DE RESPOSTA QUESTÃO DISCURSIVA 3}

Como aspecto geral considerar como adequadas e pertinentes as referências a requalificação urbana ou recuperação ou revitalização de áreas naturais (parques urbanos, margens de canais ou rios, e outros exemplos) e de áreas construídas (centros históricos, áreas degradadas, por exemplo).

Parte (a)

Espera-se que o estudante aborde como aspectos positivos os investimentos em infraestrutura urbana, tais como: saneamento básico; redes de transporte de baixo impacto ambiental. E, principalmente se refira a processos de requalificação urbana e revitalização de áreas naturais em obras voltadas para os megaeventos.

Espera-se que o estudante aborde como aspectos negativos o aumento significativo da produção de lixo; a degradação de áreas naturais e construídas, ambientalmente frágeis; congestionamento e poluições (sonora e emissão de gases) causados pelo aumento nos sistemas de transportes; e elevação do consumo energético.

Parte (b)

Espera-se que o estudante aborde como aspectos positivos: o aumento do numero de moradias; treinamento de mão de obra para a inserção no mercado de trabalho; implantação de programas de educação e conscientização ambiental e cultural; popularização do esporte como meio de inclusão social; mundialização da cultura brasileira;

Espera-se que o estudante aborde como aspectos negativos: desapropriações de áreas habitadas; especulação imobiliária; marginalização de comunidades; transferência geográfica de problemas sociais; e aumento do custo de vida, assim como uma visão crítica sobre a apropriação política do tema. 


\section{QUESTÃO DISCURSIVA 4}

\section{QUESTÃO DISCURSIVA 4}

Um dos aspectos sempre associados à arquitetura moderna é a busca de transparência, cujo objetivo principal é criar uma possibilidade maior de integração visual com o meio circundante. A obtenção de transparência implica alteração significativa das superfícies verticais das edificações, antes maciças e pouco vazadas, cada vez mais abertas e expostas a partir das primeiras décadas do século XX, com a consequente ampliação das superfícies envidraçadas.

O interesse pelo aumento da transparência, no sentido de permeabilidade visual, surgiu em países europeus de clima frio, resultando em que amplas superfícies envidraçadas constituíssem as faces dos prismas elementares que caracterizaram a arquitetura moderna nos seus primórdios. A partir do momento em que a busca da transparência começou a ser empreendida em climas tropicais e temperados, tornou-se clara a necessidade de considerar simultaneamente a proteção dos planos transparentes.

MAHFUZ, E. C. Tipo, projeto e método, construçäo interdisciplinar. Quatro partidos em debate 1960/2000. Porto Alegre: Marcavisual, 2011 . p. 41 (com adaptaçöes) Considerando as ideias apresentadas acima, redija um texto dissertativo acerca do seguinte tema:

A necessidade de proteção dos planos verticais na arquitetura brasileira.

Em seu texto, aborde os seguintes aspectos:

a) as peculiaridades das condições climático-geográficas brasileiras e a adoção de soluções internacionais; (valor: 3,0 pontos)

b) as alternativas para garantir a transparência e proteção dos planos verticais, adequadas à realidade brasileira; (valor: 4,0 pontos)

c) a importância da proteção dos planos verticais para o conforto ambiental e redução do consumo de energia nas edificações. (valor: 3,0 pontos)

\section{PADRÃO DE RESPOSTA QUESTÃO DISCURSIVA 4}

A) No Brasil, um país de dimensões continentais, com diferentes situações climáticas e geográficas, é fundamental adotar soluções locais e vernaculares. Portanto, em algumas situações, será inadequada a adoção de determinados modelos internacionais do ponto de vista apenas estético, que desconsiderem as condições climáticas brasileira.

B) as possíveis alternativas para a proteção de fachadas, citando brises móveis e fixos em fachadas onde esses recursos têm um bom desempenho, recuos, balanços e beirais que controlam a incidência solar, levando em conta o que o texto-base defende: transparência e proteção.Eventualmente poderiam ser citados exemplos de obras.

C) o impacto dessa proteção em termos de conforto térmico e lumínico para redução do consumo energético em climatização e iluminação artificiais. Considerar também que os programas computacionais possibilitam ao arquiteto prever esse impacto.

\section{QUESTÃO DISCURSIVA 5}


Os edifícios consomem $44 \%$ da energia elétrica no Brasil e $50 \%$ desse total têm consumo em edificações residenciais. A principal fonte de energia elétrica no Brasil são as hidrelétricas (95\%). Apesar de ser considerada uma energia limpa, necessita de altos investimentos financeiros em sua implantação, arrasam a fauna e flora de grandes superfícies, sem possibilidade de uso do potencial pleno em épocas de seca.

Considerando a participação percentual no consumo dos edifícios residenciais ( $22 \%$ do consumo total do país), a economia nesse setor pode ser representativa. Verificando o consumo final da região Sul, observa-se que os aspectos que mais influenciam nesse alto consumo são: os condicionadores de ar (32\%), o chuveiro elétrico (18\%) e a iluminação (8\%).

PICORAL, R.B. Arquitetura sustentável versus ganhos ambientais. In: Ferreira, M. S. et. al. (Org.) Arquitetura e urbanismo: posturas, tendências e reflexöes Porto Alegre: Livraria do Arquiteto, 2008. Volume II, p. 56

Considerando as idéias centrais desenvolvidas no texto acima, redija um texto dissertativo acerca do seguinte tema:

Arquitetura e consumo de energia.

Em seu texto, aborde os seguintes aspectos:
a) postura do arquiteto frente a esse cenário; (valor: 2,0 pontos)
b) diretrizes de projeto voltadas à economia de energia; (valor: 2,0 pontos)
c) alternativas para redução de consumo de energia em condicionamento térmico; (valor: 2,0 pontos)
d) alternativas para redução de consumo em aquecimento de água; (valor: 2,0 pontos)
e) alternativas para redução de consumo de energia em iluminação artificial. (valor: 2,0 pontos)

\section{PADRÃO DE RESPOSTA QUESTÃO DISCURSIVA 5}

Espera-se que o estudante

A) apresente uma postura crítica frente a este cenário; a importância do conhecimento técnico atualizado do arquiteto e urbanista para utilização de alternativas tecnológicas de redução do consumo energético.

B) discorra sobre o reflexo das decisões arquitetônicas no consumo de energia; o desenho deve considerar soluções que incorporem as novas tecnologias. Incorporação das alternativas concomitante à elaboração do projeto e não como adequação do projeto.

C), D) e E) apresente alternativas para redução do consumo energético em edificações especificamente em relação aos quesitos apresentados, abordando: orientação solar; ventilação natural; uso adequado de materiais de vedação e de revestimento; uso de telhados, beirais, brises ou fachadas e coberturas verdes; valorização do paisagismo considerando a vegetação local; alternativas para aquecimento e redução do consumo de água (painéis solares, aproveitamento da água da chuva, etc.); iluminação natural e artificial. 
ANEXO 2: CÁLCULO DO CONCEITO ENADE (INEP, 2008) 
Instituto Nacional de Estudos e Pesquisas Educacionais 'Anísio Teixeira' - INEP

Ministério da Educação - MEC

\section{Cálculo do Conceito ENADE}

Para descrever o cálculo do Conceito Enade, primeiramente é importante definir a unidade de observação de interesse. O Conceito Enade é calculado para cada curso ique é definido por uma instituição de ensino superior (IES) $k$, por um município $m$, por uma área de avaliação $j^{1}$. Segue um exemplo do que pode ser considerado um curso $i$ : o curso de Pedagogia, da Universidade Federal de Mato Grosso, oferecido no município de Cuiabá. As áreas de avaliação contempladas no Enade de 2010 estão descritas no Apêndice desta Nota Técnica.

A partir de 2008, o Conceito Enade passou a considerar em seu cômputo apenas o desempenho dos alunos concluintes. Assim, todos os cálculos descritos a seguir consideram apenas os alunos concluintes participantes do Enade.

O passo inicial para o cálculo do Conceito Enade de um curso $i$ é a obtenção do desempenho médio dos concluintes do curso $i$ na Formação Geral - $C_{i}^{F G}$ - e do desempenho médio dos concluintes do curso $i$ no Componente Específico - $C_{i}^{C E}$ :

$$
\begin{gathered}
C_{i}^{F G}=\frac{c_{1}^{F G}+c_{2}^{F G}+\ldots+c_{N}^{F G}}{N}=\frac{\sum_{n=1}^{N} c_{n}^{F G}}{N} \\
C_{i}^{C E}=\frac{c_{1}^{C E}+c_{2}^{C E}+\ldots+c_{N}^{C E}}{N}=\frac{\sum_{n=1}^{N} c_{n}^{C E}}{N}
\end{gathered}
$$

\footnotetext{
${ }^{1}$ Note que algumas destas áreas podem ter subáreas. Quando isso ocorre, a definição de curso também inclui esta desagregação. Assim, o curso $i$ é definido por uma IES $k$, um município $m$, uma área $j$ e uma subárea $h$.
} 
em que $c_{N}^{F G}$ e $c_{N}^{C E}$ são as notas do $\mathrm{N}$-ésimo aluno concluinte na Formação Geral e no Componente Específico; e $N$ é o número total de alunos concluintes do curso $i$ que compareceram à prova.

O segundo passo é a obtenção da média dos desempenhos médios dos concluintes obtidos para os cursos da área de avaliação $j$ na Formação Geral - $\bar{C}_{j}^{F G}$ - e da média dos desempenhos médios dos concluintes obtidos para os cursos da área de avaliação $j$ no Componente Específico - $\bar{C}_{j}^{C E}$ :

$$
\begin{aligned}
& \bar{C}_{j}^{F G}=\frac{C_{1}^{F G}+C_{2}^{F G}+\ldots+C_{K}^{F G}}{K}=\frac{\sum_{k=1}^{K} C_{k}^{F G}}{K} \\
& \bar{C}_{j}^{C E}=\frac{C_{1}^{C E}+C_{2}^{C E}+\ldots+C_{K}^{C E}}{K}=\frac{\sum_{k=1}^{K} C_{k}^{C E}}{K}
\end{aligned}
$$

em que $C_{K}^{F G}$ e $C_{K}^{C E}$ é o desempenho médio dos concluintes do K-ésimo curso e $K$ é o número total de cursos da área $j$.

E por fim, é necessário o cálculo do desvio-padrão dos desempenhos médios dos concluintes obtidos para os cursos da área de avaliação $j$ na Formação Geral - $D P_{j}^{F G}$ - e do desvio-padrão dos desempenhos médios dos concluintes obtidos para os cursos da área de avaliação $j$ no Componente Específico - $D P_{j}^{C E}$ :

$$
\begin{aligned}
& D P_{j}^{F G}=\sqrt{\frac{\left(C_{1}^{F G}-\bar{C}_{j}^{F G}\right)^{2}+\ldots+\left(C_{K}^{F G}-\bar{C}_{j}^{F G}\right)^{2}}{K-1}}=\sqrt{\frac{\sum_{k=1}^{K}\left(C_{i}^{F G}-\bar{C}_{j}^{F G}\right)^{2}}{K-1}} \\
& D P_{j}^{C E}=\sqrt{\frac{\left(C_{1}^{C E}-\bar{C}_{j}^{C E}\right)^{2}+\ldots+\left(C_{K}^{C E}-\bar{C}_{j}^{C E}\right)^{2}}{K-1}}=\sqrt{\frac{\sum_{k=1}^{K}\left(C_{i}^{C E}-\bar{C}_{j}^{C E}\right)^{2}}{K-1}}
\end{aligned}
$$


A partir da obtenção desses valores ${ }^{2}$ é possivel calcular dois termos: a nota padronizada dos concluintes na Formação Geral - $N_{F G}^{C}$ - e a nota padronizada dos concluintes no Componente Específico $-N_{C E}^{C}$. A Nota Enade do curso $i$ é a média ponderada desses dois termos: $N C=\left(0,25 \times N_{F G}^{C}\right)+\left(0,75 \times N_{C E}^{C}\right)$.

O cálculo desses termos para o curso $i$ tem como base um conceito bastante estabelecido da estatística, chamado afastamento padronizado (AP). Para obtenção do afastamento padronizado do curso $i$ na Formação Geral e no Componente Específico, subtrai-se do desempenho médio dos concluintes do curso $i$, a média dos desempenhos médios dos concluintes obtidos para os cursos da área de avaliação $j$, e divide-se o resultado dessa subtração pelo desvio padrão dos desempenhos médios dos concluintes obtidos para os cursos da área de avaliação $j$. As fórmulas são as seguintes:

$$
\begin{aligned}
& A P_{i}^{F G}=\frac{C_{i}^{F G}-\overline{C_{j}^{F G}}}{D P_{j}^{F G}} \\
& A P_{i}^{C E}=\frac{C_{i}^{C E}-\overline{C_{j}^{C E}}}{D P_{j}^{C E}}
\end{aligned}
$$

Após a padronização, para que todas as instituições tenham as notas de Formação Geral e de Conhecimento Específico variando de 0 a 5 , é feito o seguinte ajuste ${ }^{3:}$ soma-se ao afastamento padronizado de cada curso $i$ o valor absoluto do menor afastamento padronizado entre todos os cursos da área de avaliação $j$; em seguida, divide-se este resultado pela soma do maior afastamento padronizado com o módulo do menor. Finalmente, multiplica-se o resultado desse quociente por 5 . O cálculo da Nota Padronizada dos concluintes do curso $i$ em Formação Geral - $N_{F G}^{C}$ - e da Nota Padronizada dos concluintes do curso $i$ no Componente Específico - $N_{C E}^{C}$ - é expresso pelas fórmulas a seguir:

\footnotetext{
${ }^{2}$ Ver a observação número 1 colocada ao final deste texto acerca dos cálculos da média e desvio padrão por área, das medidas necessárias para a padronização.

${ }^{3}$ Os cursos que obtiveram valores de afastamento inferiores a $-3,0$ e superiores a 3,0 não foram utilizados como ponto inferior ou superior da fórmula, pelo fato de tais cursos terem desempenhos muito discrepantes dos demais da sua área de avaliação (conhecidos como outliers).
} 


$$
\begin{gathered}
N_{F G}^{C}=5 \times \frac{A P_{F G}^{C}+\mid A P_{F G}^{C} \text { inferior } \mid}{A P_{F G}^{C} \text { superior }+\mid A P_{F G}^{C} \text { inferior } \mid} \\
N_{C E}^{C}=5 \times \frac{A P_{C E}^{C}+\mid A P_{C E}^{C} \text { inferior } \mid}{A P_{C E}^{C} \text { superior }+\mid A P_{C E}^{C} \text { inferior } \mid}
\end{gathered}
$$

Os cursos com Afastamento Padronizado menor que -3,0 recebem Nota Padronizada igual a 0 (zero) e aqueles com Afastamento Padronizado maior que 3,0 recebem Nota Padronizada igual a 5 (cinco).

\section{Nota Enade}

A Nota Enade do curso $i$ é a média ponderada da nota padronizada dos concluintes na Formação Geral e no Componente Específico. A parte referente à Formação Geral contribui com $25 \%$ da nota final, enquanto a referente ao Componente Específico contribui com $75 \%$. A fórmula está descrita a seguir.

$$
N C=\left(0,75 \times N_{C E}^{C}\right)+\left(0,25 \times N_{F G}^{C}\right)
$$

\section{Observações:}

1. Para os cálculos das médias e desvios padrão de cada uma das notas de interesse (isto é, de concluintes na Formação Geral e no Componente Específico) para uma determinada área - que são os elementos necessários para a padronização - não foram incluídos os cursos que tiveram:

- nota média (na Formação Geral e/ou no Componente Específico) igual a zero. Este é o caso em que todos os alunos do curso $i$ obtêm nota zero nas provas. É importante destacar que os cálculos dos afastamentos padronizados de cada nota de cada curso são independentes. Dessa forma, um curso com média zero em uma determinada nota, por exemplo, na Formação Geral, é excluído do cálculo da média e do desvio-padrão no cômputo do afastamento padronizado da Formação Geral, e não necessariamente é excluído do cálculo da média e desvio padrão do Componente Específico, salvo o caso em que média desse curso na IES no Componente Específico também seja zero; e 
- apenas um participante concluinte fazendo as provas do ENADE. Como para estes cursos não se calcula o Conceito Enade, optou-se por excluí-los do cálculo.

2. A nota do curso obtida a partir da equação (11) é uma variável contínua no intervalo entre 0 e 5, por construção. Para a obtenção do Conceito Enade, a nota do curso foi arredondada em duas casas decimais conforme procedimento padrão. Por exemplo, caso $N C \geq 0,945, N C$ foi aproximado para 0,95 . Caso $N C<0,945, N C$ foi aproximado para 0,94 .

3. Não foram atribuídos conceitos de 1 a 5 para os seguintes casos:

- cursos com apenas um participante concluinte presente na prova do Enade. No caso em que há apenas um participante concluinte, não seria legalmente possível divulgar o Conceito Enade, visto que, na verdade, estaríamos divulgando a nota do aluno, algo não permitido.

- cursos que não contaram com nenhum aluno presente no Exame e, portanto, não é possível calcular um conceito nesses casos - estes cursos são excluídos, inclusive, da divulgação.

Os conceitos são assim distribuídos:

\begin{tabular}{|c|c|}
\hline Conceito Enade & Notas finais $(N C)$ \\
\hline 1 & 0,0 a 0,94 \\
2 & 0,95 a 1,94 \\
3 & 1,95 a 2,94 \\
4 & 2,95 a 3,94 \\
5 & 3,95 a 5,0 \\
\hline
\end{tabular}

Quadro 1: Distribuição dos conceitos 


\section{ANEXO 3: ESTRUTURA CURRICULAR DA FAU- UFRN}

\begin{tabular}{|c|c|c|c|c|}
\hline Período & COD & Nome & $\begin{array}{l}\text { Total } \\
\text { créditos }\end{array}$ & $\mathrm{CH}$ \\
\hline 10 & ARQ0511 & GEOMETRIA GRAFICA 01 & 6 & 90 \\
\hline $1 \underline{0}$ & ARQ0512 & DESENHO ARTISTICO 01 & 3 & 45 \\
\hline 10 & ARQ0513 & DESENHO DE ARQUITETURA 01 & 4 & 60 \\
\hline 10 & ARQ0514 & ESPACO E FORMA 01 & 4 & 60 \\
\hline 10 & ARQ0515 & METODOS E TECNICAS & 2 & 30 \\
\hline 1 은 & ARQ0516 & ESTETICA E HISTORIA DAS ARTES 01 & 6 & 90 \\
\hline 10 & EST0213 & ESTATISTICA APLICADA A ARQUITETURA E URBANISMO & 3 & 45 \\
\hline 20 & ARQ0521 & GEOMETRIA GRAFICA 02 & 6 & 90 \\
\hline 20 & ARQ0522 & DESENHO ARTISTICO 02 & 3 & 45 \\
\hline 20 & ARQ0523 & DESENHO DE ARQUITETURA 02 & 4 & 60 \\
\hline 20 & ARQ0524 & ESPAÇO E FORMA 02 & 4 & 60 \\
\hline 20 & - & $\begin{array}{l}\text { FUNDAMENTOS SOCIAIS DA ARQUITETURA E URBANISMO } \\
01\end{array}$ & 3 & 45 \\
\hline 20 & ARQ0526 & ESTETICA E HISTORIA DAS ARTES 02 & 4 & 60 \\
\hline 20 & ARQ0527 & TECNOLOGIA DA CONSTRUÇÃO 01 & 4 & 60 \\
\hline 30 & ARQ0531 & COMUNICACAO VISUAL & 4 & 60 \\
\hline 30 & ARQ0532 & PROJETO DE ARQUITETURA 01 & 4 & 60 \\
\hline 3은 & ARQ0525 & $\begin{array}{l}\text { FUNDAMENTOS SOCIAIS DA ARQUITETURA E URBANISMO } \\
02\end{array}$ & 3 & 45 \\
\hline 3응 & ARQ0533 & PLANEJAMENTO E PROJETO URB. E REGIONAL 01 & 3 & 45 \\
\hline 30 & ARQ0534 & HISTORIA E TEORIA DA ARQUITETURA E URB. 01 & 4 & 60 \\
\hline 30 & ARQ0535 & TOPOGRAFIA & 4 & 60 \\
\hline 30 & ARQ0536 & TECNOLOGIA DA CONSTRUCAO 02 & 4 & 60 \\
\hline 40 & ARQ0537 & FUNDAMENTOS DAS ESTRUTURAS 01 & 4 & 60 \\
\hline 40 & ARQ0541 & DESENHO AUXILIADO POR COMPUTADOR 01 & 4 & 60 \\
\hline 40 & ARQ0542 & PROJETO DE ARQUITETURA 02 & 5 & 75 \\
\hline 40 & ARQ0543 & PSICOLOGIA AMBIENTAL 01 & 3 & 45 \\
\hline 4 은 & ARQ0544 & PLANEJAMENTO E PROJETO URB. E REGIONAL 02 & 5 & 75 \\
\hline 40 & ARQ0545 & HISTORIA E TEORIA DA ARQUITETURA E URB. 02 & 4 & 60 \\
\hline 40 & ARQ0546 & FUNDAMENTOS AMBIENTAIS & 3 & 45 \\
\hline 40 & ARQ0547 & INSTALACOES 01 & 4 & 60 \\
\hline 50 & ARQ0548 & FUNDAMENTOS DAS ESTRUTURAS 02 & 4 & 60 \\
\hline 50 & ARQ0551 & DESENHO AUXILIADO POR COMPUTADOR 02 & 4 & 60 \\
\hline 5은 & ARQ0552 & PROJETO DE ARQUITETURA 03 & 5 & 75 \\
\hline 50 & ARQ0553 & PLANEJAMENTO DA PAISAGEM 01 & 3 & 45 \\
\hline 50 & ARQ0554 & PLANEJAMENTO E PROJETO URBANO E REGIONAL 03 & 5 & 75 \\
\hline 50 & ARQ0555 & HISTORIA E TEORIA DA ARQUITETURA E URBANISMO 03 & 4 & 60 \\
\hline 5은 & ARQ0556 & CONFORTO AMBIENTAL 01 & 3 & 45 \\
\hline 60 & ARQ0557 & ESTRUTURAS 01 & 4 & 60 \\
\hline 60 & ARQ0561 & PROJETO DE ARQUITETURA 04 & 5 & 75 \\
\hline 60 & ARQ0562 & PLANEJAMENTO DA PAISAGEM 02 & 3 & 45 \\
\hline 60 & ARQ0563 & PLANEJAMENTO E PROJETO URBANO E REGIONAL 04 & 6 & 90 \\
\hline
\end{tabular}




\begin{tabular}{|c|c|c|c|c|}
\hline Período & COD & Nome & $\begin{array}{l}\text { Total } \\
\text { créditos }\end{array}$ & $\mathrm{CH}$ \\
\hline 6은 & ARQ0564 & HISTORIA E TEORIA DA ARQUITETURA E URBANISMO 04 & 4 & 60 \\
\hline 60 & ARQ0565 & CONFORTO AMBIENTAL 02 & 3 & 45 \\
\hline 60 & ARQ0566 & INSTALACOES 02 & 4 & 60 \\
\hline 70 & ARQ0567 & ESTRUTURAS 02 & 4 & 60 \\
\hline 70 & ARQ0572 & PROJETO DE ARQUITETURA 05 & 6 & 90 \\
\hline 70 & ARQ0573 & PLANEJAMENTO DA PAISAGEM 03 & 3 & 45 \\
\hline 70 & ARQ0574 & PLANEJAMENTO E PROJETO URBANO E REGIONAL 05 & 8 & 120 \\
\hline 70 & ARQ0575 & PRESERVACAO E TECNICAS RETROSPECTIVAS & 3 & 45 \\
\hline 70 & ARQ0576 & CONFORTO AMBIENTAL 03 & 3 & 45 \\
\hline 80 & ARQ0581 & PROJETO DE ARQUITETURA 06 & 8 & 120 \\
\hline 80 & ARQ0582 & PSICOLOGIA AMBIENTAL 02 & 3 & 45 \\
\hline 80 & ARQ0583 & PRATICA PROFISSIONAL & 4 & 60 \\
\hline 80 & ARQ0584 & TECNOLOGIA DA CONSTRUCAO 03 & 3 & 45 \\
\hline 9음 & ARQ0253 & TÓPICOS ESPECIAIS EM PLANEJAMENTO AMBIENTAL & 4 & 60 \\
\hline 90 & ARQ0263 & TECNOLOGIAS ALTERNATIVAS DE CONFORTO AMBIENTAL & 3 & 45 \\
\hline 90 & ARQ0007 & INTRODUÇÃO AO TRABALHO FINAL DE GRADUAÇÃO & 4 & 60 \\
\hline 9o & ARQ0591 & ATELIER INTEGRADO DE ARQUITETURA E URBANISMO & 14 & 210 \\
\hline 10 은 & ARQ0008 & TFG & 0 & 0 \\
\hline 10 은 & ARQ0247 & BOTANICA APLICADA AO MEIO AMBIENTE & 3 & 45 \\
\hline Optativa & ARQ0225 & INFORMATIZACAO DO PROJETO ARQUITETONICO & 4 & 60 \\
\hline Optativa & ARQ0006 & $\begin{array}{l}\text { SISTEMAS DE INFORMAÇÃO GEOGRAFICA (SIG) APLICADOS } \\
\text { A ARQUITETURA E URBANISMO }\end{array}$ & 5 & 75 \\
\hline Optativa & ARQ0241 & ANTROPOMETRIA & 3 & 45 \\
\hline Optativa & ARQ0243 & MAQUETES E PROTOTIPOS & 3 & 45 \\
\hline Optativa & ARQ0242 & APRESENTACAO DE PROJETOS & 4 & 60 \\
\hline Optativa & ARQ0244 & MULTIMEIOS & 3 & 45 \\
\hline Optativa & ARQ0248 & AVALIAÇÃO EDIFÍCIOS & 0 & 60 \\
\hline Optativa & ARQ0245 & LINGUAGENS DA ARQUITETURA & 4 & 60 \\
\hline Optativa & ARQ0249 & INDUSTRIA DA CONSTRUCAO CIVIL & 4 & 60 \\
\hline Optativa & ARQ0252 & METODOLOGIA DO PROJETO ARQUITETONICO & 4 & 60 \\
\hline Optativa & ARQ0246 & ACESSIBILIDADE ARQUITETÔNICA & 4 & 60 \\
\hline Optativa & ARQ0250 & ARQUITETURA DE INTERIORES I & 4 & 60 \\
\hline Optativa & ARQ0251 & ARQUITETURA DE INTERIORES II & 4 & 60 \\
\hline Optativa & ARQ0254 & TÓPICOS ESPECIAIS DE POLÍTICA URBANÍSTICA & 4 & 60 \\
\hline Optativa & ARQ0255 & GESTAO MUNICIPAL E LEGISLACAO URBANISTICA & 4 & 60 \\
\hline Optativa & ARQ0258 & ARTE NO EXTREMO ORIENTE & 2 & 30 \\
\hline Optativa & ARQ0259 & TENDENCIAS ATUAIS NA ARQUITETURA & 2 & 30 \\
\hline Optativa & ARQ0260 & CULTURA BRASILEIRA & 3 & 45 \\
\hline Optativa & ARQ0261 & MORADA BRASILEIRA & 2 & 30 \\
\hline Optativa & ARQ0265 & $\begin{array}{l}\text { TÓPICOS ESPECIAIS EM HISTÓRIA DA ARQUITETURA E DO } \\
\text { URBANISMO }\end{array}$ & 3 & 45 \\
\hline Optativa & - & PRÁTICA DA CONSTRUÇÃO & 3 & 45 \\
\hline Optativa & ARQ0264 & FISICA APLICADA A ARQUITETURA & 4 & 60 \\
\hline Optativa & ARQ0268 & PESQUISA APLICADA A ARQUITETURA E URBANISMO & 3 & 45 \\
\hline
\end{tabular}




\begin{tabular}{|l|l|l|r|r|}
\hline Período & \multicolumn{1}{|c|}{ COD } & \multicolumn{1}{|c|}{ Nome } & \multicolumn{1}{c|}{$\begin{array}{c}\text { Total } \\
\text { créditos }\end{array}$} & \multicolumn{1}{c|}{ CH } \\
\hline Optativa & ARQ0269 & PESQUISA APLICADA A ARQUITETURA E URBANISMO 02 & 3 & 45 \\
\hline Optativa & - & SEMINÁRIO TEMÁTICO & 2 & 30 \\
\hline
\end{tabular}


ANEXO 4: ESTRUTURA CURRICULAR DA FAU- UFRGS

\begin{tabular}{|c|c|c|c|c|}
\hline $\begin{array}{c}\text { Etap } \\
\mathbf{a}\end{array}$ & Nome & \begin{tabular}{|c|} 
total \\
créditos
\end{tabular} & $\mathrm{CH}$ & O/E \\
\hline 1 & GEOMETRIA DESCRITIVA APLICADA À ARQUITETURA & 4 & 60 & Obrigatória \\
\hline 1 & HISTÓRIA DA ARQUITETURA E DA ARTE I & 2 & 30 & Obrigatória \\
\hline 1 & INTRODUÇÃO AO PROJETO ARQUITETÔNICO I & 9 & $\begin{array}{r}13 \\
5\end{array}$ & Obrigatória \\
\hline 1 & LINGUAGENS GRÁFICAS I & 3 & 45 & Obrigatória \\
\hline 1 & MAQUETES & 3 & 45 & Obrigatória \\
\hline 1 & TÉCNICAS DE REPRESENTAÇÃO ARQUITETÔNICA & 3 & 45 & Obrigatória \\
\hline 2 & CÁLCULO E GEOMETRIA ANALÍTICA PARA ARQUITETOS & 6 & 90 & Obrigatória \\
\hline 2 & DESENHO ARQUITETÔNICOI & 3 & 45 & Obrigatória \\
\hline 2 & HISTÓRIA DA ARQUITETURA E DA ARTE II & 2 & 30 & Obrigatória \\
\hline 2 & INFORMÁTICA APLICADA À ARQUITETURA I & 3 & 45 & Obrigatória \\
\hline 2 & INTRODUÇÃO AO PROJETO ARQUITETÔNICO II & 9 & $\begin{array}{r}13 \\
5\end{array}$ & Obrigatória \\
\hline 2 & LINGUAGENS GRÁFICAS II & 3 & 45 & Obrigatória \\
\hline 2 & PRÁTICAS SOCIAIS NA ARQUITETURA E NO URBANISMO & 2 & 30 & Obrigatória \\
\hline 3 & ARQUITETURA NO BRASIL & 4 & 60 & Obrigatória \\
\hline 3 & DESENHO ARQUITETÔNICO II & 3 & 45 & Obrigatória \\
\hline 3 & HISTÓRIA DA ARQUITETURA E DA ARTE III & 2 & 30 & Obrigatória \\
\hline 3 & INFORMÁTICA APLICADA À ARQUITETURA II & 3 & 45 & Obrigatória \\
\hline 3 & MECÂNICA PARA ARQUITETOS & 4 & 60 & Obrigatória \\
\hline 3 & PROJETO ARQUITETÔNICO I & 10 & $\begin{array}{r}15 \\
0\end{array}$ & Obrigatória \\
\hline 3 & TEORIA E ESTÉTICA DA ARQUITETURA I & 2 & 30 & Obrigatória \\
\hline 3 & TOPOGRAFIAI & 4 & 60 & Obrigatória \\
\hline 4 & DESENHO ARQUITETÔNICO III & 3 & 45 & Obrigatória \\
\hline 4 & EVOLUÇÃO URBANA & 6 & 90 & Obrigatória \\
\hline 4 & INSTALAÇÕES HIDRÁULICAS PREDIAIS A & 2 & 30 & Obrigatória \\
\hline 4 & INSTALAÇÕES HIDRÁULICAS PREDIAIS B & 2 & 30 & Obrigatória \\
\hline 4 & PROJETO ARQUITETÔNICO II & 10 & $\begin{array}{r}15 \\
0\end{array}$ & Obrigatória \\
\hline 4 & RESISTÊNCIA DOS MATERIAIS PARA ARQUITETOS & 4 & 60 & Obrigatória \\
\hline 4 & TÉCNICAS DE EDIFICAÇÃO A & 4 & 60 & Obrigatória \\
\hline 5 & ANÁLISE DOS SISTEMAS ESTRUTURAIS & 4 & 60 & Obrigatória \\
\hline 5 & ESTABILIDADE DAS EDIFICAÇÕES & 4 & 60 & Obrigatória \\
\hline 5 & HABITABILIDADE DAS EDIFICAÇÕES & 4 & 60 & Obrigatória \\
\hline 5 & PROJETO ARQUITETÔNICO III & 10 & $\begin{array}{r}15 \\
0\end{array}$ & Obrigatória \\
\hline 5 & TÉCNICAS DE EDIFICAÇÃO B & 4 & 60 & Obrigatória \\
\hline 5 & TEORIAS SOBRE O ESPAÇO URBANO & 4 & 60 & Obrigatória \\
\hline 6 & ESTRUTURAS DE AÇO E DE MADEIRA A & 4 & 60 & Obrigatória \\
\hline 6 & INSTALAÇÕES ELÉTRICAS PREDIAIS A & 4 & 60 & Obrigatória \\
\hline 6 & LUMINOTÉCNICA APLICADA À ARQUITETURA & 4 & 60 & Eletiva \\
\hline 6 & PROJETO ARQUITETÔNICO IV & 10 & 15 & Obrigatória \\
\hline
\end{tabular}




\begin{tabular}{|c|c|c|c|c|}
\hline $\begin{array}{c}\text { Etap } \\
\mathbf{a}\end{array}$ & Nome & $\begin{array}{c}\text { total } \\
\text { créditos }\end{array}$ & $\mathrm{CH}$ & O/E \\
\hline & & & 0 & \\
\hline 6 & TÉCNICAS DE EDIFICAÇÃO C & 4 & 60 & Obrigatória \\
\hline 6 & URBANISMO I & 6 & 90 & Obrigatória \\
\hline 7 & ACÚSTICA APLICADA & 2 & 30 & Obrigatória \\
\hline 7 & ESTÁGIO SUPERVISIONADO EM OBRA I & 2 & 30 & Obrigatória \\
\hline 7 & ESTRUTURA DE CONCRETO ARMADO A & 4 & 60 & Obrigatória \\
\hline 7 & MORFOLOGIA E INFRAESTRUTURA URBANA & 4 & 60 & Obrigatória \\
\hline 7 & PROJETO ARQUITETÔNICO V & 10 & $\begin{array}{r}15 \\
0 \\
\end{array}$ & Obrigatória \\
\hline 7 & TEORIA E ESTÉTICA DA ARQUITETURA II & 2 & 30 & Obrigatória \\
\hline 7 & URBANISMO II & 7 & $\begin{array}{r}10 \\
5\end{array}$ & Obrigatória \\
\hline 8 & ESTÁGIO SUPERVISIONADO EM OBRA II & 2 & 30 & Obrigatória \\
\hline 8 & ESTRUTURA DE CONCRETO ARMADO B & 4 & 60 & Obrigatória \\
\hline 8 & LEGISLAÇÃO E EXERCÍCIO PROFISSIONAL NA ARQUITETURA & 2 & 30 & Obrigatória \\
\hline 8 & PLANEJAMENTO E GESTÃO URBANA & 4 & 60 & Obrigatória \\
\hline 8 & PROJETO ARQUITETÔNICO VI & 10 & $\begin{array}{r}15 \\
0 \\
\end{array}$ & Obrigatória \\
\hline 8 & URBANISMO III & 7 & $\begin{array}{r}10 \\
5\end{array}$ & Obrigatória \\
\hline 9 & CLIMATIZAÇÃO ARTIFICIAL - ARQUITETURA & 2 & 30 & Obrigatória \\
\hline 9 & ECONOMIA DA CONSTRUÇÃO & 4 & 60 & Obrigatória \\
\hline 9 & PROJETO ARQUITETÔNICO VII & 10 & $\begin{array}{r}15 \\
0 \\
\end{array}$ & Obrigatória \\
\hline 9 & TÉCNICAS RETROSPECTIVAS & 4 & 60 & Obrigatória \\
\hline 9 & URBANISMO IV & 7 & $\begin{array}{r}10 \\
5\end{array}$ & Obrigatória \\
\hline 10 & $\begin{array}{l}\text { TRABALHO DE CONCLUSÃO DE CURSO DE ARQUITETURA E } \\
\text { URBANISMO }\end{array}$ & 0 & $\begin{array}{r}36 \\
0\end{array}$ & Obrigatória \\
\hline & ANÁLISE DE DADOS E MODELO URBANO & 4 & 60 & Eletiva \\
\hline & ARQUITETURA DE INTERIORES I & 6 & 90 & Eletiva \\
\hline & ARQUITETURA DE INTERIORES II & 6 & 90 & Eletiva \\
\hline & CIRCULAÇÃO E TRANSPORTES URBANOS & 4 & 60 & Eletiva \\
\hline & EDIFICAÇÃO INDUSTRIALIZADA & 2 & 30 & Eletiva \\
\hline & ESTRATÉGIAS GENERATIVAS DE PROJETO I & 2 & 30 & Eletiva \\
\hline & ESTRATÉGIAS GENERATIVAS DE PROJETO II & 4 & 60 & Eletiva \\
\hline & ESTRUTURAS DE EDIFÍCIOS & 4 & 60 & Eletiva \\
\hline & ESTUDO DA VEGETAÇÃO & 3 & 45 & Eletiva \\
\hline & ESTUDOS DE SOCIOLOGIA URBANA & 4 & 60 & Eletiva \\
\hline & EVOLUÇÃO URBANA NO BRASIL & 3 & 45 & Eletiva \\
\hline & FOTOGRAFIA APLICADA À ARQUITETURA & 6 & 90 & Eletiva \\
\hline & FOTOINTERPRETAÇÃO APLICADA AO URBANISMO & 4 & 60 & Eletiva \\
\hline & GERENCIAMENTO DA DRENAGEM URBANA & 4 & 60 & Eletiva \\
\hline & HABITABILIDADE B & 2 & 30 & Eletiva \\
\hline & INTRODUÇÃO À INFORMÁTICA & 4 & 60 & Eletiva \\
\hline
\end{tabular}




\begin{tabular}{|c|c|c|c|c|}
\hline $\begin{array}{c}\text { Etap } \\
\text { a }\end{array}$ & Nome & $\begin{array}{c}\text { total } \\
\text { créditos }\end{array}$ & $\mathrm{CH}$ & O/E \\
\hline & INTRODUÇÃO AO TRABALHO FINAL DE GRADUAÇÃO & 2 & 30 & Eletiva \\
\hline & INTRODUÇÃO ECOLOGIA & 2 & 30 & Eletiva \\
\hline & MOBILIÁRIO E COMUNICAÇÃO VISUAL URBANA & 2 & 30 & Eletiva \\
\hline & PAISAGISMO E MEIO AMBIENTE & 2 & 30 & Eletiva \\
\hline & PERCEPÇÃO AMBIENTAL E URBANISMO & 4 & 60 & Eletiva \\
\hline & PLANO DIRETOR - CONTEÚDO E TENDÊNCIAS & 2 & 30 & Eletiva \\
\hline & $\begin{array}{l}\text { TÓPICOS ESP EM LEGISL E EXERC PROFISSIONAL NA } \\
\text { ARQUITETURA I-C }\end{array}$ & 2 & 30 & Eletiva \\
\hline & TÓPICOS ESPECIAIS EM ARQUITETURA NO BRASIL - C & 2 & 30 & Eletiva \\
\hline & $\begin{array}{l}\text { TÓPICOS ESPECIAIS EM EXPRESSÃO E REPRESENTAÇÃO } \\
\text { GRÁFICA I-A }\end{array}$ & 6 & 90 & Eletiva \\
\hline & $\begin{array}{l}\text { TÓPICOS ESPECIAIS EM EXPRESSÃO E REPRESENTAÇÃO } \\
\text { GRÁFICA I-B }\end{array}$ & 4 & 60 & Eletiva \\
\hline & $\begin{array}{l}\text { TÓPICOS ESPECIAIS EM EXPRESSÃO E REPRESENTAÇÃO } \\
\text { GRÁFICA I-C }\end{array}$ & 2 & 30 & Eletiva \\
\hline & $\begin{array}{l}\text { TÓPICOS ESPECIAIS EM EXPRESSÃO E REPRESENTAÇÃO } \\
\text { GRÁFICA II - A }\end{array}$ & 6 & 90 & Eletiva \\
\hline & $\begin{array}{l}\text { TÓPICOS ESPECIAIS EM EXPRESSÃO E REPRESENTAÇÃO } \\
\text { GRÁFICA II-B } \\
\end{array}$ & 4 & 60 & Eletiva \\
\hline & $\begin{array}{l}\text { TÓPICOS ESPECIAIS EM EXPRESSÃO E REPRESENTAÇÃO } \\
\text { GRÁFICA II-C }\end{array}$ & 2 & 30 & Eletiva \\
\hline & $\begin{array}{l}\text { TÓPICOS ESPECIAIS EM EXPRESSÃO E REPRESENTAÇÃO } \\
\text { GRÁFICA III-A }\end{array}$ & 6 & 90 & Eletiva \\
\hline & $\begin{array}{l}\text { TÓPICOS ESPECIAIS EM EXPRESSÃO E REPRESENTAÇÃO } \\
\text { GRÁFICA III-B } \\
\end{array}$ & 4 & 60 & Eletiva \\
\hline & $\begin{array}{l}\text { TÓPICOS ESPECIAIS EM EXPRESSÃO E REPRESENTAÇÃO } \\
\text { GRÁFICA III-C }\end{array}$ & 2 & 30 & Eletiva \\
\hline & $\begin{array}{l}\text { TÓPICOS ESPECIAIS EM HISTÓRIA DA ARQUITETURA E DA } \\
\text { ARTE }\end{array}$ & 2 & 30 & Eletiva \\
\hline & $\begin{array}{l}\text { TÓPICOS ESPECIAIS EM HISTÓRIA DA ARQUITETURA E DA } \\
\text { ARTE II - B1 }\end{array}$ & 4 & 60 & Eletiva \\
\hline & $\begin{array}{l}\text { TÓPICOS ESPECIAIS EM HISTÓRIA DA ARQUITETURA E DA } \\
\text { ARTE II - B2 }\end{array}$ & 4 & 60 & Eletiva \\
\hline & $\begin{array}{l}\text { TÓPICOS ESPECIAIS EM INFORMÁTICA APLICADA À } \\
\text { ARQUITETURA I - A }\end{array}$ & 6 & 90 & Eletiva \\
\hline & $\begin{array}{l}\text { TÓPICOS ESPECIAIS EM INFORMÁTICA APLICADA À } \\
\text { ARQUITETURA I - B }\end{array}$ & 4 & 60 & Eletiva \\
\hline & $\begin{array}{l}\text { TÓPICOS ESPECIAIS EM INFORMÁTICA APLICADA À } \\
\text { ARQUITETURA I-C }\end{array}$ & 2 & 30 & Eletiva \\
\hline & $\begin{array}{l}\text { TÓPICOS ESPECIAIS EM INFORMÁTICA APLICADA À } \\
\text { ARQUITETURA II - A }\end{array}$ & 6 & 90 & Eletiva \\
\hline & $\begin{array}{l}\text { TÓPICOS ESPECIAIS EM INFORMÁTICA APLICADA À } \\
\text { ARQUITETURA II - B }\end{array}$ & 4 & 60 & Eletiva \\
\hline & $\begin{array}{l}\text { TÓPICOS ESPECIAIS EM INFORMÁTICA APLICADA À } \\
\text { ARQUITETURA II - C }\end{array}$ & 2 & 30 & Eletiva \\
\hline & $\begin{array}{l}\text { TÓPICOS ESPECIAIS EM INTRODUÇÃO AO PROJETO } \\
\text { ARQUITETÔNICO I-A }\end{array}$ & 6 & 90 & Eletiva \\
\hline & TÓPICOS ESPECIAIS EM INTRODUÇÃO AO PROJETO & 4 & 60 & Eletiva \\
\hline
\end{tabular}




\begin{tabular}{|c|c|c|c|c|}
\hline $\begin{array}{c}\text { Etap } \\
\text { a }\end{array}$ & Nome & $\begin{array}{l}\text { total } \\
\text { créditos }\end{array}$ & $\mathbf{C H}$ & O/E \\
\hline & ARQUITETÔNICO I - B & & & \\
\hline & $\begin{array}{l}\text { TÓPICOS ESPECIAIS EM INTRODUÇÃO AO PROJETO } \\
\text { ARQUITETÔNICO I - C }\end{array}$ & 2 & 30 & Eletiva \\
\hline & $\begin{array}{l}\text { TÓPICOS ESPECIAIS EM INTRODUÇÃO AO PROJETO } \\
\text { ARQUITETÔNICO II - A }\end{array}$ & 6 & 90 & Eletiva \\
\hline & $\begin{array}{l}\text { TÓPICOS ESPECIAIS EM INTRODUÇÃO AO PROJETO } \\
\text { ARQUITETÔNICO II - B }\end{array}$ & 4 & 60 & Eletiva \\
\hline & $\begin{array}{l}\text { TÓPICOS ESPECIAIS EM INTRODUÇÃO AO PROJETO } \\
\text { ARQUITETÔNICO II - C }\end{array}$ & 2 & 30 & Eletiva \\
\hline & TÓPICOS ESPECIAIS EM PROJETO ARQUITETÔNICO I-A & 6 & 90 & Eletiva \\
\hline & TÓPICOS ESPECIAIS EM PROJETO ARQUITETÔNICO I-B & 4 & 60 & Eletiva \\
\hline & TÓPICOS ESPECIAIS EM PROJETO ARQUITETÔNICO I-C & 2 & 30 & Eletiva \\
\hline & TÓPICOS ESPECIAIS EM PROJETO ARQUITETÔNICO II-A & 6 & 90 & Eletiva \\
\hline & TÓPICOS ESPECIAIS EM PROJETO ARQUITETÔNICO II-B & 4 & 60 & Eletiva \\
\hline & TÓPICOS ESPECIAIS EM PROJETO ARQUITETÔNICO II-C & 2 & 30 & Eletiva \\
\hline & TÓPICOS ESPECIAIS EM PROJETO ARQUITETÔNICO III-A & 6 & 90 & Eletiva \\
\hline & TÓPICOS ESPECIAIS EM PROJETO ARQUITETÔNICO III-B & 4 & 60 & Eletiva \\
\hline & TÓPICOS ESPECIAIS EM PROJETO ARQUITETÔNICO III-C & 2 & 30 & Eletiva \\
\hline & $\begin{array}{l}\text { TÓPICOS ESPECIAIS EM TEORIA E ESTÉTICA DA } \\
\text { ARQUITETURA }\end{array}$ & 2 & 30 & Eletiva \\
\hline & $\begin{array}{l}\text { TÓPICOS ESPECIAIS EM TEORIA E ESTÉTICA DA } \\
\text { ARQUITETURA I-C }\end{array}$ & 2 & 30 & Eletiva \\
\hline & $\begin{array}{l}\text { TÓPICOS ESPECIAIS EM TEORIAS SOBRE O ESPAÇO URBANO } \\
1-\mathrm{B}\end{array}$ & 4 & 60 & Eletiva \\
\hline & $\begin{array}{l}\text { TÓPICOS ESPECIAIS EM TEORIAS SOBRE O ESPAÇO URBANO } \\
1-\mathrm{C}\end{array}$ & 2 & 30 & Eletiva \\
\hline & TÓPICOS ESPECIAIS EM URBANISMO I-A & 6 & 90 & Eletiva \\
\hline & TÓPICOS ESPECIAIS EM URBANISMO I-B & 4 & 60 & Eletiva \\
\hline & TÓPICOS ESPECIAIS EM URBANISMO I-C & 2 & 30 & Eletiva \\
\hline & TÓPICOS ESPECIAIS EM URBANISMO II-A & 6 & 90 & Eletiva \\
\hline & TÓPICOS ESPECIAIS EM URBANISMO II-B & 4 & 60 & Eletiva \\
\hline & TÓPICOS ESPECIAIS EM URBANISMO II-C & 2 & 30 & Eletiva \\
\hline & TÓPICOS ESPECIAIS EM URBANISMO III-A & 6 & 90 & Eletiva \\
\hline & TÓPICOS ESPECIAIS EM URBANISMO III-B & 4 & 60 & Eletiva \\
\hline & TÓPICOS ESPECIAIS EM URBANISMO III-C & 2 & 30 & Eletiva \\
\hline
\end{tabular}




\section{ANEXO 5: ESTRUTURA CURRICULAR DA FAU- USP}

\begin{tabular}{|c|c|c|c|c|c|c|}
\hline COD & Nome & $\begin{array}{l}\text { Créd. } \\
\text { Aula (1= } \\
\text { 15h.a) }\end{array}$ & $\begin{array}{c}\text { Créd. } \\
\text { Trab (1 = } \\
\text { 30h.a.) }\end{array}$ & $\begin{array}{c}\text { Total } \\
\text { créditos }\end{array}$ & $\mathrm{CH}$ & O/E \\
\hline AUH0150 & História e Teorias da Arquitetura I & 4 & 0 & 4 & 60 & Obrigatória \\
\hline AUH0308 & História da Arte I & 4 & 0 & 4 & 60 & Obrigatória \\
\hline AUP0608 & Fundamentos de Projeto & 16 & 2 & 18 & 300 & Obrigatória \\
\hline AUT0182 & Construção do Edifício 1 & 4 & 0 & 4 & 60 & Obrigatória \\
\hline AUT0258 & Conforto Ambiental 1 - Fundamentos & 2 & 1 & 3 & 60 & Obrigatória \\
\hline AUT0510 & Geometria Aplicada à Produção Arquitetônica & 2 & 0 & 2 & 30 & Obrigatória \\
\hline PCC0201 & Geometria Descritiva & 2 & 0 & 2 & 30 & Obrigatória \\
\hline AUH0152 & História e Teorias da Arquitetura II & 4 & 0 & 4 & 60 & Obrigatória \\
\hline AUH0514 & $\begin{array}{l}\text { Fundamentos Sociais da Arquitetura e } \\
\text { Urbanismo I }\end{array}$ & 4 & 0 & 4 & 60 & Obrigatória \\
\hline AUP0146 & Arquitetura - Projeto I & 4 & 0 & 4 & 60 & Obrigatória \\
\hline AUP0332 & Comunicação Visual - Linguagens & 8 & 1 & 9 & 150 & Obrigatória \\
\hline AUP0650 & Arquitetura da Paisagem & 8 & 1 & 9 & 150 & Obrigatória \\
\hline AUT0184 & Construção do Edifício 2 & 4 & 0 & 4 & 60 & Obrigatória \\
\hline AUT0260 & Conforto Ambiental 2 - Ergonomia & 2 & 0 & 2 & 30 & Obrigatória \\
\hline AUT0512 & Desenho Arquitetônico & 2 & 0 & 2 & 30 & Obrigatória \\
\hline PTR0101 & Topografia & 4 & 0 & 4 & 60 & Obrigatória \\
\hline AUH0154 & História e Teorias da Arquitetura III & 4 & 0 & 4 & 60 & Obrigatória \\
\hline AUH0516 & $\begin{array}{l}\text { Fundamentos Sociais da Arquitetura e } \\
\text { Urbanismo II }\end{array}$ & 4 & 0 & 4 & 60 & Obrigatória \\
\hline AUP0148 & Arquitetura - Projeto II & 4 & 1 & 5 & 90 & Obrigatória \\
\hline AUP0266 & Planejamento Urbano I & 8 & 1 & 9 & 150 & Obrigatória \\
\hline AUP0652 & Planejamento da Paisagem & 8 & 1 & 9 & 150 & Obrigatória \\
\hline AUT0186 & Construção do Edifício 3 & 4 & 0 & 4 & 60 & Obrigatória \\
\hline AUT0514 & Computação Gráfica & 2 & 2 & 4 & 90 & Obrigatória \\
\hline MAT0141 & Cálculo & 4 & 2 & 6 & 120 & Obrigatória \\
\hline PHD0313 & Instalações e Equipamentos Hidráulicos I & 4 & 0 & 4 & 60 & Obrigatória \\
\hline AUH0131 & $\begin{array}{l}\text { Arquitetura do Renascimento - Itália, Portugal } \\
\text { e Espanha }\end{array}$ & 4 & 0 & 4 & 60 & Eletiva \\
\hline AUH0327 & Preceptivas Artísticas & 4 & 0 & 4 & 60 & Eletiva \\
\hline AUH0236 & Estudos de Urbanização I & 4 & 0 & 4 & 60 & Obrigatória \\
\hline AUH0310 & História da Arte II & 2 & 0 & 2 & 30 & Obrigatória \\
\hline AUP0268 & Planejamento Urbano II & 4 & 1 & 5 & 90 & Obrigatória \\
\hline AUP0334 & Comunicação Visual do Edifício e da Cidade & 8 & 1 & 9 & 150 & Obrigatória \\
\hline AUP0446 & Design do Objeto & 8 & 1 & 9 & 150 & Obrigatória \\
\hline AUT0188 & Construção do Edifício 4 & 4 & 0 & 4 & 60 & Obrigatória \\
\hline AUT0262 & Conforto Ambiental 3 - Iluminação & 4 & 1 & 5 & 90 & Obrigatória \\
\hline AUH0101 & $\begin{array}{l}\text { Arte e Arquitetura no Brasil nos Três } \\
\text { Primeiros Séculos }\end{array}$ & 2 & 0 & 2 & 30 & Eletiva \\
\hline AUH0109 & História da Arquitetura Contemporânea & 2 & 0 & 2 & 30 & Eletiva \\
\hline AUH0115 & Moradias Paulistas & 2 & 0 & 2 & 30 & Eletiva \\
\hline AUH0117 & Arte e Arquitetura No Brasil Nos Seculos XIX e & 4 & 0 & 4 & 60 & Eletiva \\
\hline
\end{tabular}




\begin{tabular}{|c|c|c|c|c|c|c|}
\hline COD & Nome & $\begin{array}{l}\text { Créd. } \\
\text { Aula (1= } \\
\text { 15h.a) }\end{array}$ & $\begin{array}{c}\text { Créd. } \\
\text { Trab (1 = } \\
\text { 30h.a.) }\end{array}$ & $\begin{array}{c}\text { Total } \\
\text { créditos }\end{array}$ & $\mathbf{C H}$ & O/E \\
\hline & $\mathrm{XX}$ & & & & & \\
\hline AUH0119 & História de Paisagem Brasileira & 2 & 0 & 2 & 30 & Eletiva \\
\hline AUH0121 & Estética do Projeto Arquitetônico & 2 & 0 & 2 & 30 & Eletiva \\
\hline AUH0125 & Arquitetos Paulistas & 4 & 0 & 4 & 60 & Eletiva \\
\hline AUH0221 & Assentamentos Urbanos Populares & 2 & 0 & 2 & 30 & Eletiva \\
\hline AUH0233 & A Praça Como Arquitetura & 2 & 0 & 2 & 30 & Eletiva \\
\hline AUH0313 & Arte e Vida Urbana & 2 & 0 & 2 & 30 & Eletiva \\
\hline AUH0401 & História da Técnica no Brasil & 2 & 0 & 2 & 30 & Eletiva \\
\hline AUH0405 & Evolução do Equipamento da Habitação & 2 & 0 & 2 & 30 & Eletiva \\
\hline AUH0505 & Habitação Popular Paulistana & 2 & 0 & 2 & 30 & Eletiva \\
\hline AUH0535 & Teoria da Renda da Terra & 2 & 0 & 2 & 30 & Eletiva \\
\hline AUH0238 & Estudos da Urbanização II & 4 & 0 & 4 & 60 & Obrigatória \\
\hline AUH0412 & $\begin{array}{l}\text { Técnicas Retrospectivas. Estudo e } \\
\text { Preservação dos Bens Culturais. } \\
\end{array}$ & 4 & 0 & 4 & 60 & Obrigatória \\
\hline AUP0150 & Arquitetura - Projeto III & 8 & 1 & 9 & 150 & Obrigatória \\
\hline AUP0270 & \begin{tabular}{|l|} 
Planejamento de Estruturas Urbanas e \\
Regionais - A Formação do Espaço Nacional
\end{tabular} & 4 & 1 & 5 & 90 & Obrigatória \\
\hline AUP0448 & Arquitetura e Indústria & 8 & 1 & 9 & 150 & Obrigatória \\
\hline AUT0190 & Construção do Edifício 5 & 2 & 0 & 2 & 30 & Obrigatória \\
\hline AUT0516 & Estatística Aplicada & 2 & 0 & 2 & 30 & Obrigatória \\
\hline PEF0522 & Mecânica dos Solos e Fundações & 4 & 0 & 4 & 60 & Obrigatória \\
\hline PEF2601 & Estruturas na Arquitetura I: Fundamentos & 4 & 0 & 4 & 60 & Obrigatória \\
\hline 1601103 & Cultura, Paisagem e Cidade & 2 & 0 & 2 & 30 & Eletiva \\
\hline AUH0227 & $\begin{array}{l}\text { Elementos para uma Teoria do Urbanismo. } \\
\text { aTratadistica da Cidade }\end{array}$ & 4 & 0 & 4 & 60 & Eletiva \\
\hline AUH0231 & Demografia e Urbanização & 4 & 0 & 4 & 60 & Eletiva \\
\hline AUH0241 & $\begin{array}{l}\text { Teoria, História e Instrumentos para a Crítica } \\
\text { e o Projeto Urbano }\end{array}$ & 4 & 2 & 6 & 120 & Eletiva \\
\hline AUH0321 & Contribuição à Análise da Forma & 4 & 0 & 4 & 60 & Eletiva \\
\hline AUH0323 & História da Arte no Brasil & 4 & 0 & 4 & 60 & Eletiva \\
\hline AUH0325 & Aspectos da Linguagem Contemporânea & 4 & 0 & 4 & 60 & Eletiva \\
\hline AUH0533 & $\begin{array}{l}\text { Fundamentos a Critica da Arquitetura e do } \\
\text { Urbanismo }\end{array}$ & 4 & 0 & 4 & 60 & Eletiva \\
\hline AUH0240 & História do Urbanismo Contemporâneo & 4 & 0 & 4 & 60 & Obrigatória \\
\hline AUP0152 & Arquitetura - Projeto IV & 8 & 1 & 9 & 150 & Obrigatória \\
\hline AUP0272 & Organização Urbana e Planejamento & 8 & 1 & 9 & 150 & Obrigatória \\
\hline AUT0192 & Infra-estrutura Urbana e Meio Ambiente & 4 & 0 & 4 & 60 & Obrigatória \\
\hline AUT0264 & Conforto Ambiental 4 - Térmica & 2 & 1 & 3 & 60 & Obrigatória \\
\hline AUT0266 & Conforto Ambiental 5 - Acústica & 2 & 1 & 3 & 60 & Obrigatória \\
\hline PEF2602 & $\begin{array}{l}\text { Estruturas na Arquitetura I I: Sistemas } \\
\text { Reticulados }\end{array}$ & 4 & 0 & 4 & 60 & Obrigatória \\
\hline AUH0235 & A Forma Plástica Urbana & 4 & 0 & 4 & 60 & Eletiva \\
\hline AUH0237 & Urbanização e Urbanismo no Brasil & 2 & 0 & 2 & 30 & Eletiva \\
\hline AUH0239 & Questões Gerais sobre Urbanização e & 4 & 0 & 4 & 60 & Eletiva \\
\hline
\end{tabular}




\begin{tabular}{|c|c|c|c|c|c|c|}
\hline COD & Nome & $\begin{array}{l}\text { Créd. } \\
\text { Aula (1= } \\
\text { 15h.a) }\end{array}$ & $\begin{array}{c}\text { Créd. } \\
\text { Trab (1 = } \\
\text { 30h.a.) }\end{array}$ & $\begin{array}{c}\text { Total } \\
\text { créditos }\end{array}$ & $\mathrm{CH}$ & O/E \\
\hline & Urbanismo & & & & & \\
\hline AUH0525 & Formas de Produção do Espaço Urbano & 4 & 0 & 4 & 60 & Eletiva \\
\hline AUH0539 & Historiografia Crítica e Projeto Social & 4 & 0 & 4 & 60 & Eletiva \\
\hline AUT0139 & $\begin{array}{l}\text { Razão e Ser das Manifestações Patológicas } \\
\text { Prediais }\end{array}$ & 4 & 1 & 5 & 90 & Eletiva \\
\hline 1601112 & Estágio Obrigatório Supervisionado & 4 & 10 & 14 & 360 & Obrigatória \\
\hline AUH0156 & História e Teorias da Arquitetura IV & 4 & 0 & 4 & 60 & Obrigatória \\
\hline AUP0154 & Arquitetura - Projeto V & 8 & 1 & 9 & 150 & Obrigatória \\
\hline AUP0274 & $\begin{array}{l}\text { Desenho Urbano e Projeto dos Espaços da } \\
\text { Cidade }\end{array}$ & 8 & 1 & 9 & 150 & Obrigatória \\
\hline AUT0268 & Conforto Ambiental 6-Integradas & 4 & 1 & 5 & 90 & Obrigatória \\
\hline AUT0518 & Projeto dos Custos & 4 & 0 & 4 & 60 & Obrigatória \\
\hline PEF2603 & $\begin{array}{l}\text { Estruturas na Arquitetura III: Sistemas } \\
\text { Reticulados e Laminares }\end{array}$ & 4 & 0 & 4 & 60 & Obrigatória \\
\hline 1601113 & Estágio Supervisionado: Transição & 2 & 3 & 5 & 120 & Eletiva \\
\hline AUH0127 & $\begin{array}{l}\text { Conservação e Restauração do Patrimônio } \\
\text { Arquitetônico }\end{array}$ & 4 & 0 & 4 & 60 & Eletiva \\
\hline AUH0229 & $\begin{array}{l}\text { Intervenção na Cidade Existente: Percursos } \\
\text { No Desenho Urbano }\end{array}$ & 4 & 0 & 4 & 60 & Eletiva \\
\hline AUH0329 & Arte Italiana do Renascimento e do Barroco & 4 & 0 & 4 & 60 & Eletiva \\
\hline PEF2604 & Estruturas na Arquitetura I V: Projeto & 4 & 0 & 4 & 60 & Obrigatória \\
\hline 1601115 & Atividades Complementares: Transição & 0 & 0 & 0 & 0 & Eletiva \\
\hline AUH0129 & $\begin{array}{l}\text { Arquitetura Moderna e Contemporânea no } \\
\text { Brasil }\end{array}$ & 4 & 0 & 4 & 60 & Eletiva \\
\hline AUP0171 & Arquitetura Projeto/OPTATIVA I & 4 & 1 & 5 & 90 & Eletiva \\
\hline AUP0177 & Projeto do Edifício e Dimensão Urbana I & 4 & 1 & 5 & 90 & Eletiva \\
\hline AUP0179 & Projetos Normativos I & 4 & 1 & 5 & 90 & Eletiva \\
\hline AUP0183 & A Estrutura no Projeto do Edifício & 4 & 1 & 5 & 90 & Eletiva \\
\hline AUP0185 & Reciclagem e Reforma de Edificação & 4 & 1 & 5 & 90 & Eletiva \\
\hline AUP0343 & Desenho Gráfico Experimental & 4 & 1 & 5 & 90 & Eletiva \\
\hline AUP0345 & Linguagem e Cor & 4 & 1 & 5 & 90 & Eletiva \\
\hline AUP0347 & Linguagem e Expressão & 4 & 1 & 5 & 90 & Eletiva \\
\hline AUP0349 & Linguagens Aplicadas ao Projeto & 4 & 1 & 5 & 90 & Eletiva \\
\hline AUP0351 & Linguagens Gráficas & 4 & 1 & 5 & 90 & Eletiva \\
\hline AUP0353 & O Espaço de Representação & 4 & 1 & 5 & 90 & Eletiva \\
\hline AUP0355 & Identidade Visual Gráfica & 4 & 1 & 5 & 90 & Eletiva \\
\hline AUP0357 & $\begin{array}{l}\text { Linguagens dos Sist. de Comunicação Visual } \\
\text { Aplicados à Arquitetura }\end{array}$ & 4 & 1 & 5 & 90 & Eletiva \\
\hline AUP0361 & $\begin{array}{l}\text { Linguagem dos Recursos de Reprodução } \\
\text { Gráfica }\end{array}$ & 4 & 1 & 5 & 90 & Eletiva \\
\hline AUP0363 & $\begin{array}{l}\text { Linguagens dos Sistemas de Comunicação } \\
\text { Visual Aplicados à Cidade }\end{array}$ & 4 & 1 & 5 & 90 & Eletiva \\
\hline AUP0365 & $\begin{array}{l}\text { Cidade em Movimento - Linguagens } \\
\text { Associadas ao Vídeo, Computador e Internet } \\
\text { na Comunicação Visual do Edifício e da }\end{array}$ & 4 & 1 & 5 & 90 & Eletiva \\
\hline
\end{tabular}




\begin{tabular}{|c|c|c|c|c|c|c|}
\hline COD & Nome & $\begin{array}{l}\text { Créd. } \\
\text { Aula (1= } \\
\text { 15h.a) }\end{array}$ & $\begin{array}{c}\text { Créd. } \\
\text { Trab (1 = } \\
\text { 30h.a.) }\end{array}$ & $\begin{array}{c}\text { Total } \\
\text { créditos }\end{array}$ & $\mathrm{CH}$ & O/E \\
\hline & Cidade & & & & & \\
\hline AUP0367 & $\begin{array}{l}\text { Modernidade Líquida: estratégias em design } \\
\text { visual }\end{array}$ & 4 & 1 & 5 & 90 & Eletiva \\
\hline AUP0369 & Poéticas da Deriva Urbana & 4 & 1 & 5 & 90 & Eletiva \\
\hline AUP0371 & $\begin{array}{l}\text { Design, Ambiente e Interfaces: Equipamentos } \\
\text { Urbanos e de Arquitetura Como Design de } \\
\text { Interface }\end{array}$ & 4 & 1 & 5 & 90 & Eletiva \\
\hline AUP0373 & Ateliê Livre & 4 & 1 & 5 & 90 & Eletiva \\
\hline AUP0449 & $\begin{array}{l}\text { Design Arquitetônico: Uma Experiência } \\
\text { Projetual }\end{array}$ & 4 & 1 & 5 & 90 & Eletiva \\
\hline AUP0451 & Produção e Consumo do Objeto Industrial & 4 & 1 & 5 & 90 & Eletiva \\
\hline AUP0457 & $\begin{array}{l}\text { Projeto de Sistemas de Objeto para o Edifício } \\
\text { e o Ambiente }\end{array}$ & 4 & 1 & 5 & 90 & Eletiva \\
\hline AUP0467 & $\begin{array}{l}\text { Desenho Industrial Aplicado ao Projeto de } \\
\text { Embarcações I }\end{array}$ & 4 & 1 & 5 & 90 & Eletiva \\
\hline AUP0471 & $\begin{array}{l}\text { Design da Revolução Industrial Mecânica à } \\
\text { Eletro-eletrônica }\end{array}$ & 4 & 1 & 5 & 90 & Eletiva \\
\hline AUP0473 & $\begin{array}{l}\text { Desenho de Equipamentos em Áreas de } \\
\text { Intervenção Urbana }\end{array}$ & 4 & 1 & 5 & 90 & Eletiva \\
\hline AUP0475 & Modelos Físicos para Desenho Industrial & 4 & 1 & 5 & 90 & Eletiva \\
\hline AUP0477 & Materiais, Processos e Formas & 4 & 1 & 5 & 90 & Eletiva \\
\hline AUP0515 & Gestão Ambiental Urbana & 4 & 1 & 5 & 90 & Eletiva \\
\hline AUP0517 & Novas Formas de Gestão Urbana & 4 & 1 & 5 & 90 & Eletiva \\
\hline AUP0523 & Informática e Planejamento Urbano & 4 & 1 & 5 & 90 & Eletiva \\
\hline AUP0547 & $\begin{array}{l}\text { Ambiente Construído e Desenvolvimento } \\
\text { Sustentável }\end{array}$ & 4 & 1 & 5 & 90 & Eletiva \\
\hline AUP0549 & $\begin{array}{l}\text { Áreas Comerciais: Planejamento e } \\
\text { Intervenção }\end{array}$ & 4 & 1 & 5 & 90 & Eletiva \\
\hline AUP0551 & $\begin{array}{l}\text { Urbanismo e a Cidade Moderna: Idéias, } \\
\text { Projetos e Realizações }\end{array}$ & 4 & 1 & 5 & 90 & Eletiva \\
\hline AUP0553 & Habitaçao para a População de Baixa Renda & 4 & 1 & 5 & 90 & Eletiva \\
\hline AUP0555 & Elementos de Planejamento de Transportes & 4 & 1 & 5 & 90 & Eletiva \\
\hline AUP0557 & Planejamento de Áreas Industriais & 4 & 1 & 5 & 90 & Eletiva \\
\hline AUP0559 & Planejamento Setorial e Orgnização Urbana & 4 & 1 & 5 & 90 & Eletiva \\
\hline AUP0561 & $\begin{array}{l}\text { Metodologia na Elaboraçao de Planos } \\
\text { Diretores Municipais }\end{array}$ & 4 & 1 & 5 & 90 & Eletiva \\
\hline AUP0563 & Estruturação do Espaço Urbano & 4 & 1 & 5 & 90 & Eletiva \\
\hline AUP0565 & Planejamento Urbano Estratégico & 4 & 1 & 5 & 90 & Eletiva \\
\hline AUP0567 & Renovação Urbana & 4 & 1 & 5 & 90 & Eletiva \\
\hline AUP0569 & Planejamento de Bairros & 4 & 1 & 5 & 90 & Eletiva \\
\hline AUP0571 & Os Saberes sobre a Cidade & 4 & 1 & 5 & 90 & Eletiva \\
\hline AUP0573 & Desenho Urbano: da Teoria ao Projeto & 4 & 1 & 5 & 90 & Eletiva \\
\hline AUP0661 & Paisagismo: Projeto de Plantação & 4 & 1 & 5 & 90 & Eletiva \\
\hline AUP0663 & Paisagismo: Praça & 4 & 1 & 5 & 90 & Eletiva \\
\hline AUP0665 & Arte e Projeto da Paisagem & 4 & 1 & 5 & 90 & Eletiva \\
\hline
\end{tabular}




\begin{tabular}{|c|c|c|c|c|c|c|}
\hline COD & Nome & $\begin{array}{l}\text { Créd. } \\
\text { Aula (1= } \\
\text { 15h.a) }\end{array}$ & $\begin{array}{c}\text { Créd. } \\
\text { Trab (1 = } \\
\text { 30h.a.) }\end{array}$ & $\begin{array}{c}\text { Total } \\
\text { créditos }\end{array}$ & $\mathrm{CH}$ & O/E \\
\hline AUT0131 & Técnicas Alternativas na Construção & 4 & 0 & 4 & 60 & Eletiva \\
\hline AUT0133 & $\begin{array}{l}\text { Terminais Aeroportuários de Passageiros: } \\
\text { Aspectos Programáticos }\end{array}$ & 4 & 0 & 4 & 60 & Eletiva \\
\hline AUT0135 & $\begin{array}{l}\text { Avaliação Pós-ocupação (apo) Como } \\
\text { Metodologia de Projeto }\end{array}$ & 4 & 0 & 4 & 60 & Eletiva \\
\hline AUT0211 & $\begin{array}{l}\text { Conforto Ambiental - Desempenho de } \\
\text { Componentes Construtivos }\end{array}$ & 4 & 0 & 4 & 60 & Eletiva \\
\hline AUT0213 & $\begin{array}{l}\text { O Projeto da lluminação no Exercício da } \\
\text { Arquitetura }\end{array}$ & 4 & 0 & 4 & 60 & Eletiva \\
\hline AUT0215 & $\begin{array}{l}\text { Ergonomia Aplicada ao Projeto e } \\
\text { Dimensionamento dos Espaços da Habitação. }\end{array}$ & 4 & 0 & 4 & 60 & Eletiva \\
\hline AUT0217 & $\begin{array}{l}\text { Ergonomia Aplicada ao Planejamento e } \\
\text { Projeto do Mobiliário Urbano. }\end{array}$ & 4 & 0 & 4 & 60 & Eletiva \\
\hline AUT0219 & $\begin{array}{l}\text { Ergonomia Aplicada ao Projeto e } \\
\text { Dimensionamento dos Espaços para } \\
\text { Comércio de Varejo. }\end{array}$ & 4 & 0 & 4 & 60 & Eletiva \\
\hline AUT0221 & $\begin{array}{l}\text { Arquitetura, Ambiente e Desenvolvimento } \\
\text { Sustentável }\end{array}$ & 4 & 0 & 4 & 60 & Eletiva \\
\hline AUT0223 & $\begin{array}{l}\text { Adequação dos Projetos de Edificações a Leis } \\
\text { e Normas Sobre Acústica }\end{array}$ & 4 & 0 & 4 & 60 & Eletiva \\
\hline AUT0571 & Desenho de Observação & 4 & 0 & 4 & 60 & Eletiva \\
\hline AUT0573 & O Espaço e Suas Representações & 4 & 0 & 4 & 60 & Eletiva \\
\hline AUT0575 & \begin{tabular}{|l|} 
Representações do Espaço Arquitetônico: \\
Práticas e Procedimentos Contemporâneos I
\end{tabular} & 4 & 0 & 4 & 60 & Eletiva \\
\hline AUT0577 & $\begin{array}{l}\text { Percepção e Organização Espacial Bi e } \\
\text { Tridimensional } \\
\end{array}$ & 4 & 0 & 4 & 60 & Eletiva \\
\hline AUT0579 & Acessibilidade e Segurança de Edificações & 4 & 0 & 4 & 60 & Eletiva \\
\hline AUT0581 & $\begin{array}{l}\text { O Mercado Imobiliário e a Intervenção } \\
\text { Pública }\end{array}$ & 4 & 0 & 4 & 60 & Eletiva \\
\hline PEF2605 & $\begin{array}{l}\text { Prática de Empreendimentos na Área de } \\
\text { Edificações }\end{array}$ & 2 & 2 & 4 & 90 & Eletiva \\
\hline 1601101 & Trabalho Final de Graduação I & 4 & 2 & 6 & 120 & Obrigatória \\
\hline AUT0520 & $\begin{array}{l}\text { Prática Profissional e Organização do } \\
\text { Trabalho } \\
\end{array}$ & 2 & 0 & 2 & 30 & Obrigatória \\
\hline AUP0173 & Arquitetura Projeto/OPTATIVA II & 4 & 1 & 5 & 90 & Eletiva \\
\hline AUP0459 & $\begin{array}{l}\text { Desenho de Elementos Construtivos - } \\
\text { Tradição Construtivos Brasileira } \\
\end{array}$ & 4 & 1 & 5 & 90 & Eletiva \\
\hline AUP0461 & Construção de Modelos Analógicos & 4 & 1 & 5 & 90 & Eletiva \\
\hline AUP0469 & $\begin{array}{l}\text { Desenho Industrial Aplicado ao Projeto de } \\
\text { Embarcações II }\end{array}$ & 4 & 1 & 5 & 90 & Eletiva \\
\hline AUP0479 & Design para a Sustentabilidade & 4 & 1 & 5 & 90 & Eletiva \\
\hline AUP0535 & Instrumentos de Planejamento & 4 & 1 & 5 & 90 & Eletiva \\
\hline AUP0539 & $\begin{array}{l}\text { Planejamento de Áreas Especiais: Favelas e } \\
\text { Cortiços }\end{array}$ & 4 & 1 & 5 & 90 & Eletiva \\
\hline AUP0545 & Habitação de Interesse Social & 4 & 1 & 5 & 90 & Eletiva \\
\hline AUP0651 & Desenho da Paisagem Urbana & 4 & 1 & 5 & 90 & Eletiva \\
\hline
\end{tabular}




\begin{tabular}{|c|c|c|c|c|c|c|}
\hline COD & Nome & $\begin{array}{l}\text { Créd. } \\
\text { Aula (1= } \\
\text { 15h.a) }\end{array}$ & \begin{tabular}{|c|} 
Créd. \\
Trab (1 = \\
30h.a.)
\end{tabular} & $\begin{array}{l}\text { Total } \\
\text { créditos }\end{array}$ & $\mathrm{CH}$ & O/E \\
\hline AUP0657 & Paisagismo: Sistemas de Espaços Livres & 4 & 1 & 5 & 90 & Eletiva \\
\hline AUP0659 & Paisagismo: Parque Urbano & 4 & 1 & 5 & 90 & Eletiva \\
\hline AUP0667 & Análise Paisagístico-ambiental & 4 & 1 & 5 & 90 & Eletiva \\
\hline AUP0669 & Gestão da Paisagem e do Ambiente & 4 & 1 & 5 & 90 & Eletiva \\
\hline AUT0557 & $\begin{array}{l}\text { Técnicas para Planejamento Urbano e } \\
\text { Regional }\end{array}$ & 4 & 0 & 4 & 60 & Eletiva \\
\hline AUT0559 & Metodologia de Planejamento Participativo & 4 & 0 & 4 & 60 & Eletiva \\
\hline AUT0563 & Recursos Gráficos Avançados na Computação & 4 & 0 & 4 & 60 & Eletiva \\
\hline AUT0583 & $\begin{array}{l}\text { Elementos Complementares ao Projeto } \\
\text { Gráfico do Edifício }\end{array}$ & 4 & 0 & 4 & 60 & Eletiva \\
\hline AUT0585 & Tecnologia da Cor & 4 & 0 & 4 & 60 & Eletiva \\
\hline PEF0606 & $\begin{array}{l}\text { Estruturas de Aço para Edifícios. Aspectos } \\
\text { Tecnológicos e de Concepção }\end{array}$ & 4 & 0 & 4 & 60 & Eletiva \\
\hline 1601102 & Trabalho Final de Graduação II & 4 & 2 & 6 & 120 & Obrigatória \\
\hline
\end{tabular}




\begin{tabular}{|c|c|c|c|c|c|c|}
\hline Período & Nome & $\begin{array}{l}\text { Créd. } \\
\text { Aula } \\
\text { teórica }\end{array}$ & $\begin{array}{c}\text { Créd. } \\
\text { Aula } \\
\text { prática }\end{array}$ & $\begin{array}{c}\text { Total } \\
\text { créditos } \\
\text { (teoria, } \\
\text { prática, } \\
\text { extensão } \\
\text { e estudo } \\
\text { pelo } \\
\text { aluno) } \\
\end{array}$ & CH & O/E \\
\hline Período 1 & INTRO ARQUITETURA E URBANISMO & 2 & 2 & 4 & 60 & Obrigatória \\
\hline Período 1 & PROJETO ARQUITETONICO 1 & 4 & 4 & 8 & 120 & Obrigatória \\
\hline Período 1 & DESENHO ARQUITETONICO & 0 & 4 & 4 & 60 & Obrigatória \\
\hline Período 1 & DESENHO E PLASTICA 1 & 0 & 4 & 4 & 60 & Obrigatória \\
\hline Período 1 & GEOMETRIA CONSTRUTIVA & 2 & 2 & 4 & 60 & Obrigatória \\
\hline Período 1 & INTROD TECNOL ARQUIT URBANISMO & 4 & 0 & 4 & 60 & Obrigatória \\
\hline Período 2 & TOPOGRAFIA & 1 & 3 & 4 & 60 & Obrigatória \\
\hline Período 2 & PROJETO ARQ LINGUA E EXPRESSÃO & 2 & 6 & 8 & 120 & Obrigatória \\
\hline Período 2 & EST AMBIENTAIS-BIOCLIMATISMO & 2 & 0 & 2 & 30 & Obrigatória \\
\hline Período 2 & SISTEMAS ESTRUT NA ARQUITETURA & 4 & 4 & 8 & 120 & Obrigatória \\
\hline Período 2 & HIST ARQUITETURA E DA ARTE 1 & 4 & 0 & 4 & 60 & Obrigatória \\
\hline Período 2 & MODEL TRID DIGITAL EM ARQUITET & 1 & 1 & 2 & 30 & Obrigatória \\
\hline Período 3 & PROJ ARQUITETURA - HABITAÇÃO & 2 & 6 & 8 & 120 & Obrigatória \\
\hline Período 3 & DESENHO E PLASTICA 2 & 0 & 4 & 4 & 60 & Obrigatória \\
\hline Período 3 & CONFORTO TERMICO AMBIENTAL & 2 & 2 & 4 & 60 & Obrigatória \\
\hline Período 3 & SIST ESTRUT EM CONCRETO ARMADO & 4 & 4 & 8 & 120 & Obrigatória \\
\hline Período 3 & HIST ARQUITETURA E DA ARTE 2 & 4 & 0 & 4 & 60 & Obrigatória \\
\hline Período 3 & MODEL DA INF DA CONSTRUÇÃO-BIM & 1 & 1 & 2 & 30 & Obrigatória \\
\hline Período 4 & PROJ DE ARQ DE GRANDES VAOS & 2 & 6 & 8 & 120 & Obrigatória \\
\hline Período 4 & SISTEMAS ESTRUTURAIS EM AÇO & 2 & 2 & 4 & 60 & Obrigatória \\
\hline Período 4 & ARQ E URB DA SOCIED INDUSTRIAL & 4 & 0 & 4 & 60 & Obrigatória \\
\hline Período 4 & CONFORTO SONORO & 2 & 0 & 2 & 30 & Obrigatória \\
\hline Período 4 & CONFORTO AMBIENTAL LUMINOSO & 2 & 0 & 2 & 30 & Obrigatória \\
\hline Período 5 & INSTALAÇÕES E EQUIPAMENTOS 1 & 2 & 2 & 4 & 60 & Obrigatória \\
\hline Período 5 & PROJ ARQUIT DE EDIF EM ALTURA & 2 & 6 & 8 & 120 & Obrigatória \\
\hline Período 5 & SIST ESTRUT EM MADEIRA & 2 & 2 & 4 & 60 & Obrigatória \\
\hline Período 5 & ARQ E URB BRASIL COL E IMPERIO & 4 & 0 & 4 & 60 & Obrigatória \\
\hline Período 5 & MATERIAIS DE CONSTRUÇÃO-TEORIA & 4 & 0 & 4 & 60 & Obrigatória \\
\hline Período 5 & MAT DE CONSTRUÇÃO -EXPERIMENT & 0 & 2 & 2 & 30 & Obrigatória \\
\hline Período 6 & TECNICAS DE CONSTRUCAO & 2 & 2 & 4 & 60 & Obrigatória \\
\hline Período 6 & PROJ DE ARQ DE FUNC COMPLEXAS & 2 & 6 & 8 & 120 & Obrigatória \\
\hline Período 6 & PROJETO PAISAGÍSTICO 1 & 2 & 6 & 8 & 120 & Obrigatória \\
\hline Período 6 & ARQ E URB BRASIL CONTEMPORANEO & 4 & 0 & 4 & 60 & Obrigatória \\
\hline Período 6 & INFRA-ESTRUTURA URBANA & 2 & 0 & 2 & 30 & Obrigatória \\
\hline Período 7 & PROJETO DE URBANISMO 1 & 2 & 6 & 8 & 120 & Obrigatória \\
\hline Período 7 & ARQ URB DA ATUALIDADE & 4 & 0 & 4 & 60 & Obrigatória \\
\hline Período 7 & PLANEJAMENTO URBANO & 2 & 2 & 4 & 60 & Obrigatória \\
\hline
\end{tabular}




\begin{tabular}{|c|c|c|c|c|c|c|}
\hline Período & Nome & $\begin{array}{c}\text { Créd. } \\
\text { Aula } \\
\text { teórica }\end{array}$ & $\begin{array}{l}\text { Créd. } \\
\text { Aula } \\
\text { prática }\end{array}$ & $\begin{array}{c}\text { Total } \\
\text { créditos } \\
\text { (teoria, } \\
\text { prática, } \\
\text { extensão } \\
\text { e estudo } \\
\text { pelo } \\
\text { aluno) } \\
\end{array}$ & $\mathrm{CH}$ & O/E \\
\hline Período 7 & ESTÉTICA E HISTÓRIA DA ARTE & 4 & 0 & 4 & 60 & Obrigatória \\
\hline Período 8 & PROJETO DE URBANISMO 2 & 2 & 6 & 8 & 120 & Obrigatória \\
\hline Período 8 & PROJ ARQ/URB- TÉCN RETROSP & 4 & 4 & 8 & 120 & Obrigatória \\
\hline Período 9 & ENSAIO TEOR HIST ARQ E URB & 4 & 0 & 4 & 60 & Obrigatória \\
\hline Período 9 & INTRO TRAB FINAL GRADUAÇÃO & 2 & 2 & 4 & 60 & Obrigatória \\
\hline $\begin{array}{l}\text { Período } \\
10\end{array}$ & TRAB FINAL GRAD ARQUIT E URBAN & 0 & 4 & 4 & 60 & Obrigatória \\
\hline Optativa & 155616 - AÇO E ARQUITETURA & 2 & 2 & 4 & 60 & Optativa \\
\hline Optativa & 145491 - ANALISE DA IMAGEM & 2 & 2 & 4 & 60 & Optativa \\
\hline Optativa & 135020 - ANTROPOLOGIA CULTURAL & 0 & 0 & 0 & 0 & Optativa \\
\hline Optativa & 135224 - ANTROPOLOGIA DA ARTE & 4 & 0 & 4 & 60 & Optativa \\
\hline Optativa & 125172 - APRENDIZAGEM NO ENSINO & 4 & 0 & 4 & 60 & Optativa \\
\hline Optativa & 154792 - ARQ E URB DA AMERICA LATINA & 4 & 0 & 4 & 60 & Optativa \\
\hline Optativa & 154962 - ARQUITETURA E ESTETICA & 2 & 2 & 4 & 60 & Optativa \\
\hline Optativa & 155454 - ARTE COMPARADA & 2 & 2 & 4 & 60 & Optativa \\
\hline Optativa & 155462 - ARTE E FILOSOFIA & 2 & 2 & 4 & 60 & Optativa \\
\hline Optativa & 155438 - ATELIE PRO ARQ URB SUSTENTÁVEL & 2 & 4 & 6 & 90 & Optativa \\
\hline Optativa & 185515 - AVAL POL GOVERNAM NO BRASIL & 4 & 0 & 4 & 60 & Optativa \\
\hline Optativa & 155501 - AVAL PÓS-OCUP DE ESP URB & 2 & 2 & 4 & 60 & Optativa \\
\hline Optativa & 123013 - BIOLOGIA GERAL & 0 & 4 & 4 & 60 & Optativa \\
\hline Optativa & 155446 - BRASÍLIA, EXP URB-PRÁT /TEORIA & 2 & 2 & 4 & 60 & Optativa \\
\hline Optativa & 153851 - CENOGRAFIA 1 & 2 & 2 & 4 & 60 & Optativa \\
\hline Optativa & 122408 - CIENCIAS DO AMBIENTE & 2 & 0 & 2 & 30 & Optativa \\
\hline Optativa & 155292 - COMP GRAF APL ARQ URBANISMO 1 & 2 & 2 & 4 & 60 & Optativa \\
\hline Optativa & 154954 - COMP GRAF APL ARQ URBANISMO 2 & 2 & 2 & 4 & 60 & Optativa \\
\hline Optativa & 154679 - CONF AMBIENTAL LUMIN E ACUSTI & 2 & 2 & 4 & 60 & Optativa \\
\hline Optativa & 155098 - CONFIGURACAO URBANA & 4 & 0 & 4 & 60 & Optativa \\
\hline Optativa & 139416 - CULTURA BRASILEIRA 1 & 4 & 0 & 4 & 60 & Optativa \\
\hline Optativa & 206253 - DESENHO DE ARQUITETURA & 1 & 1 & 2 & 30 & Optativa \\
\hline Optativa & 155365 - DESENHO E PLASTICA 3 & 0 & 4 & 4 & 60 & Optativa \\
\hline Optativa & 153133 - DESENHO GEOMETRICO & 2 & 4 & 6 & 90 & Optativa \\
\hline Optativa & 153141 - DESENHO PERSPECTIVO & 2 & 2 & 4 & 60 & Optativa \\
\hline Optativa & 162019 - DESENHO TECNICO & 0 & 4 & 4 & 60 & Optativa \\
\hline Optativa & 122114 - ECOLOGIA GERAL & 2 & 4 & 6 & 90 & Optativa \\
\hline Optativa & 132543 - ECONOMIA URBANA & 4 & 0 & 4 & 60 & Optativa \\
\hline Optativa & 153010 - ELEM LING ESTÉTICA HIST ARTE 2 & 4 & 0 & 4 & 60 & Optativa \\
\hline Optativa & 153001 - ELEN LING ESTÉTICA HIST ARTE 1 & 4 & 0 & 4 & 60 & Optativa \\
\hline Optativa & 155535 - ENSAIO EM TEC DA ARQ E URB & 4 & 0 & 4 & 60 & Optativa \\
\hline Optativa & 124664 - ERGONOMIA 1 & 4 & 2 & 6 & 90 & Optativa \\
\hline
\end{tabular}




\begin{tabular}{|c|c|c|c|c|c|c|}
\hline Período & Nome & $\begin{array}{l}\text { Créd. } \\
\text { Aula } \\
\text { teórica }\end{array}$ & $\begin{array}{c}\text { Créd. } \\
\text { Aula } \\
\text { prática }\end{array}$ & $\begin{array}{c}\text { Total } \\
\text { créditos } \\
\text { (teoria, } \\
\text { prática, } \\
\text { extensão } \\
\text { e estudo } \\
\text { pelo } \\
\text { aluno) } \\
\end{array}$ & $\mathrm{CH}$ & O/E \\
\hline Optativa & 154610 - ESPACO,EXPRESSAO E SIGNIFICADO & 2 & 2 & 4 & 60 & Optativa \\
\hline Optativa & 115011 - ESTATISTICA APLICADA & 4 & 2 & 6 & 90 & Optativa \\
\hline Optativa & 137545 - ESTETICA & 4 & 0 & 4 & 60 & Optativa \\
\hline Optativa & 155381 - ESTÉTICA DO ESPAÇO & 2 & 2 & 4 & 60 & Optativa \\
\hline Optativa & 145033 - ESTÉTICA E CULTURA DE MASSA & 4 & 0 & 4 & 60 & Optativa \\
\hline Optativa & 155560 - ESTRUT ARQUIT AMB CONSTRUÍDO & 4 & 0 & 4 & 60 & Optativa \\
\hline Optativa & 154385 - ESTRUTURAS ARQUITETONICAS 3 & 4 & 4 & 8 & 120 & Optativa \\
\hline Optativa & 154911 - ESTRUTURAS ESPECIAIS EM ARQUIT & 4 & 0 & 4 & 60 & Optativa \\
\hline Optativa & 155187 - ESTRUTURAS URBANAS & 2 & 2 & 4 & 60 & Optativa \\
\hline Optativa & 155373 - ESTUDOS ESP EM TECNOLOGIA & 2 & 2 & 4 & 60 & Optativa \\
\hline Optativa & 137413 - EVOL PENS FILOS E CIENTIFICO & 4 & 0 & 4 & 60 & Optativa \\
\hline Optativa & 137928 - FILOSOFIA DA ARTE & 4 & 0 & 4 & 60 & Optativa \\
\hline Optativa & 137626 - FILOSOFIA SOCIAL E POLITICA & 4 & 0 & 4 & 60 & Optativa \\
\hline Optativa & 118001 - FISICA 1 & 4 & 0 & 4 & 60 & Optativa \\
\hline Optativa & 118010 - FISICA 1 EXPERIMENTAL & 0 & 2 & 2 & 30 & Optativa \\
\hline Optativa & 132039 - FORMACAO ECONOMICA DO BRASIL & 4 & 0 & 4 & 60 & Optativa \\
\hline Optativa & 145319 - FOTOGRAFIA E ILUMINACAO 1 & 0 & 2 & 2 & 30 & Optativa \\
\hline Optativa & 138177 - FOTOINTERPRETACAO & 2 & 4 & 6 & 90 & Optativa \\
\hline Optativa & 205877 - FRANCÊS 1 & 4 & 0 & 4 & 60 & Optativa \\
\hline Optativa & 142000 - FRANCES INSTRUMENTAL 1 & 4 & 0 & 4 & 60 & Optativa \\
\hline Optativa & 142590 - FRANCES INSTRUMENTAL 2 & 2 & 2 & 4 & 60 & Optativa \\
\hline Optativa & 191311 - FUND DA ARTE NA EDUCACAO & 4 & 0 & 4 & 60 & Optativa \\
\hline Optativa & 153699 - FUND DA LINGUAGEM VISUAL & 2 & 4 & 6 & 90 & Optativa \\
\hline Optativa & 153681 - FUNDAMENTOS DE LINGUAGEM & 4 & 0 & 4 & 60 & Optativa \\
\hline Optativa & 138312 - GEOGRAFIA DO MEIO AMBIENTE & 2 & 2 & 4 & 60 & Optativa \\
\hline Optativa & 138266 - GEOGRAFIA HUMANA 1 & 2 & 2 & 4 & 60 & Optativa \\
\hline Optativa & 138282 - GEOGRAFIA HUMANA E ECONOMICA & 4 & 0 & 4 & 60 & Optativa \\
\hline Optativa & 138053 - GEOGRAFIA REGIONAL 1 & 4 & 0 & 4 & 60 & Optativa \\
\hline Optativa & 138193 - GEOGRAFIA URBANA 1 & 4 & 0 & 4 & 60 & Optativa \\
\hline Optativa & 112011 - GEOLOGIA GERAL & 2 & 4 & 6 & 90 & Optativa \\
\hline Optativa & 154822 - GEOMETRIA DA FORMA & 2 & 2 & 4 & 60 & Optativa \\
\hline Optativa & 162027 - GEOMETRIA DESCRITIVA & 4 & 0 & 4 & 60 & Optativa \\
\hline Optativa & 138258 - GEOMORFOLOGIA & 2 & 2 & 4 & 60 & Optativa \\
\hline Optativa & 163007 - GERENCIA DE PROJ EM ENGENHARIA & 1 & 3 & 4 & 60 & Optativa \\
\hline Optativa & 155527 - GESTÃO AMBIENTAL URBANA & 2 & 2 & 4 & 60 & Optativa \\
\hline Optativa & 139203 - HIST SOC E POL DO BRASIL & 4 & 0 & 4 & 60 & Optativa \\
\hline Optativa & 137791 - HISTORIA DA CIENCIA & 4 & 0 & 4 & 60 & Optativa \\
\hline Optativa & 132021 - HISTORIA ECONOMICA GERAL & 4 & 0 & 4 & 60 & Optativa \\
\hline Optativa & 139190 - HISTORIA SOCIAL E POL GERAL & 4 & 0 & 4 & 60 & Optativa \\
\hline
\end{tabular}




\begin{tabular}{|c|c|c|c|c|c|c|}
\hline Período & Nome & $\begin{array}{l}\text { Créd. } \\
\text { Aula } \\
\text { teórica }\end{array}$ & $\begin{array}{c}\text { Créd. } \\
\text { Aula } \\
\text { prática }\end{array}$ & $\begin{array}{c}\text { Total } \\
\text { créditos } \\
\text { (teoria, } \\
\text { prática, } \\
\text { extensão } \\
\text { e estudo } \\
\text { pelo } \\
\text { aluno) } \\
\end{array}$ & $\mathrm{CH}$ & O/E \\
\hline Optativa & 154211 - INDUSTRIALIZACAO DA CONSTRUCAO & 2 & 2 & 4 & 60 & Optativa \\
\hline Optativa & 145971 - INGLÊS INSTRUMENTAL 1 & 2 & 2 & 4 & 60 & Optativa \\
\hline Optativa & 142573 - INGLÊS INSTRUMENTAL 2 & 2 & 2 & 4 & 60 & Optativa \\
\hline Optativa & 155161 - INIC AO PROJETO PAISAGISTICO & 2 & 6 & 8 & 120 & Optativa \\
\hline Optativa & 199982 - INTRO A POL CIENT TECNOLOGICA & 4 & 0 & 4 & 60 & Optativa \\
\hline Optativa & 139033 - INTRO AO ESTUDO DA HISTORIA & 4 & 0 & 4 & 60 & Optativa \\
\hline Optativa & 145165 - INTRO AS HIST EM QUADRINHOS & 2 & 2 & 4 & 60 & Optativa \\
\hline Optativa & 185850 - INTROD POLITICAS PUBLICAS & 4 & 0 & 4 & 60 & Optativa \\
\hline Optativa & 155128 - INTROD PROJETO ARQUITETURA 1 & 4 & 8 & 12 & 180 & Optativa \\
\hline Optativa & 181013 - INTRODUCAO A ADMINISTRACAO & 4 & 0 & 4 & 60 & Optativa \\
\hline Optativa & 113093 - INTRODUCAO A ALGEBRA LINEAR & 4 & 0 & 4 & 60 & Optativa \\
\hline Optativa & 135011 - INTRODUÇÃO A ANTROPOLOGIA & 4 & 0 & 4 & 60 & Optativa \\
\hline Optativa & 113913 - INTRODUCAO A CIEN COMPUTACAO & 2 & 2 & 4 & 60 & Optativa \\
\hline Optativa & 185035 - INTRODUÇÃO A CIÊNCIA POLÍTICA & 4 & 0 & 4 & 60 & Optativa \\
\hline Optativa & 132012 - INTRODUÇÃO A ECONOMIA & 4 & 0 & 4 & 60 & Optativa \\
\hline Optativa & 191019 - INTRODUCAO A EDUCACAO & 4 & 0 & 4 & 60 & Optativa \\
\hline Optativa & 191299 - INTRODUCAO A EDUCACAO ESPECIAL & 2 & 2 & 4 & 60 & Optativa \\
\hline Optativa & 153061 - INTRODUCAO A ESCULTURA & 0 & 6 & 6 & 90 & Optativa \\
\hline Optativa & 137553 - INTRODUCAO A FILOSOFIA & 4 & 0 & 4 & 60 & Optativa \\
\hline Optativa & 145335 - INTRODUCAO A FOTOGRAFIA & 3 & 1 & 4 & 60 & Optativa \\
\hline Optativa & 156281 - INTRODUCAO A GRAVURA & 0 & 6 & 6 & 90 & Optativa \\
\hline Optativa & 156272 - INTRODUCAO A PINTURA & 0 & 6 & 6 & 90 & Optativa \\
\hline Optativa & 124010 - INTRODUÇÃO A PSICOLOGIA & 4 & 0 & 4 & 60 & Optativa \\
\hline Optativa & 134465 - INTRODUÇÃO A SOCIOLOGIA & 4 & 0 & 4 & 60 & Optativa \\
\hline Optativa & 153702 - INTRODUCAO AO DES INDUSTRIAL & 2 & 2 & 4 & 60 & Optativa \\
\hline Optativa & 153052 - INTRODUCAO AO DESENHO & 0 & 6 & 6 & 90 & Optativa \\
\hline Optativa & 184039 - INTRODUCAO AO DIREITO 1 & 4 & 0 & 4 & 60 & Optativa \\
\hline Optativa & 136581 - INTRODUCAO AO SERVICO SOCIAL & 4 & 0 & 4 & 60 & Optativa \\
\hline Optativa & 156264 - INTRODUCAO AOS MULTI MEIOS & 0 & 6 & 6 & 90 & Optativa \\
\hline Optativa & 206911 - INVEÇÕES PATENTE ARQ URBANISMO & 2 & 2 & 4 & 60 & Optativa \\
\hline Optativa & 140481 - LEITURA E PRODUÇÃO DE TEXTOS & 2 & 2 & 4 & 60 & Optativa \\
\hline Optativa & 142204 - LÍNGUA ALEMÃ 1 & 4 & 0 & 4 & 60 & Optativa \\
\hline Optativa & 147630 - LINGUA CHINESA 1 & 2 & 2 & 4 & 60 & Optativa \\
\hline Optativa & 147648 - LÍNGUA CHINESA 2 & 2 & 2 & 4 & 60 & Optativa \\
\hline Optativa & 147656 - LINGUA CHINESA 3 & 2 & 2 & 4 & 60 & Optativa \\
\hline Optativa & 142328 - LÍNGUA ESPANHOLA 1 & 2 & 2 & 4 & 60 & Optativa \\
\hline Optativa & 142247 - LÍNGUA JAPONESA 1 & 4 & 0 & 4 & 60 & Optativa \\
\hline Optativa & 150649 - LÍNGUA SINAIS BRAS - BÁSICO & 2 & 2 & 4 & 60 & Optativa \\
\hline Optativa & 113018 - MATEMATICA 1 & 4 & 0 & 4 & 60 & Optativa \\
\hline
\end{tabular}




\begin{tabular}{|c|c|c|c|c|c|c|}
\hline Período & Nome & $\begin{array}{c}\text { Créd. } \\
\text { Aula } \\
\text { teórica }\end{array}$ & $\begin{array}{l}\text { Créd. } \\
\text { Aula } \\
\text { prática }\end{array}$ & $\begin{array}{c}\text { Total } \\
\text { créditos } \\
\text { (teoria, } \\
\text { prática, } \\
\text { extensão } \\
\text { e estudo } \\
\text { pelo } \\
\text { aluno) } \\
\end{array}$ & $\mathbf{C H}$ & O/E \\
\hline Optativa & 113026 - MATEMATICA 2 & 4 & 0 & 4 & 60 & Optativa \\
\hline Optativa & 122416 - MEIO AMBIENTE FISICO & 2 & 2 & 4 & 60 & Optativa \\
\hline Optativa & 154156 - MET TEC PROJ ARQUITETONICA & 2 & 2 & 4 & 60 & Optativa \\
\hline Optativa & $\begin{array}{l}122483 \text { - MORFOLO TAXONOMIA } \\
\text { FANEROGAMAS }\end{array}$ & 2 & 4 & 6 & 90 & Optativa \\
\hline Optativa & 154733 - MORFOLOGIA ARQUITETONICA & 2 & 2 & 4 & 60 & Optativa \\
\hline Optativa & 153117 - MORFOLOGIA GEOMETRICA & 2 & 2 & 4 & 60 & Optativa \\
\hline Optativa & 155136 - MORFOLOGIA URBANA & 2 & 2 & 4 & 60 & Optativa \\
\hline Optativa & 153621 - OF BASICA DE ARTES CENICAS 1 & 2 & 4 & 6 & 90 & Optativa \\
\hline Optativa & 153320 - OFICINA BAS ARTES PLASTICAS 1 & 0 & 6 & 6 & 90 & Optativa \\
\hline Optativa & 153044 - OFICINA BASICA DE DESENHO & 0 & 6 & 6 & 90 & Optativa \\
\hline Optativa & 144002 - OFICINA BASICA DE MÚSICA 1 & 0 & 4 & 4 & 60 & Optativa \\
\hline Optativa & 153338 - OFICINA DE FOTOGRAFIA 1 & 0 & 4 & 4 & 60 & Optativa \\
\hline Optativa & 153346 - OFICINA DE FOTOGRAFIA 2 & 0 & 4 & 4 & 60 & Optativa \\
\hline Optativa & 153354 - OFICINA DE FOTOGRAFIA 3 & 2 & 4 & 6 & 90 & Optativa \\
\hline Optativa & 154946 - OFICINA DE MAQUETE & 0 & 4 & 4 & 60 & Optativa \\
\hline Optativa & 194221 - ORGAN DA EDUCACAO BRASILEIRA & 3 & 1 & 4 & 60 & Optativa \\
\hline Optativa & 165727 - PAINEIS DE MADEIRA & 2 & 2 & 4 & 60 & Optativa \\
\hline Optativa & 124575 - PERCEPCAO & 4 & 2 & 6 & 90 & Optativa \\
\hline Optativa & 154881 - PLANEJAMENTO DA PAISAGEM & 2 & 2 & 4 & 60 & Optativa \\
\hline Optativa & 155233 - PLANEJAMENTO HABITACIONAL & 4 & 0 & 4 & 60 & Optativa \\
\hline Optativa & 136794 - POL SOCIAL ESP 1 - HABITACAO & 2 & 2 & 4 & 60 & Optativa \\
\hline Optativa & 155578 - PRÁT DE ESCR MOD DE ARQ URB 1 & 0 & 4 & 4 & 60 & Optativa \\
\hline Optativa & 155586 - PRÁT DE ESCR MOD DE ARQ URB 2 & 0 & 4 & 4 & 60 & Optativa \\
\hline Optativa & 155594 - PRÁT DE ESCR MOD DE ARQ URB 3 & 0 & 4 & 4 & 60 & Optativa \\
\hline Optativa & 155608 - PRÁT DE ESCR MOD DE ARQ URB 4 & 0 & 4 & 4 & 60 & Optativa \\
\hline Optativa & 175013 - PRÁTICA DESPORTIVA 1 & 0 & 2 & 2 & 30 & Optativa \\
\hline Optativa & 175021 - PRATICA DESPORTIVA 2 & 0 & 0 & 0 & 0 & Optativa \\
\hline Optativa & 175307 - PRATICA DESPORTIVA 3 & 0 & 0 & 0 & 0 & Optativa \\
\hline Optativa & 154326 - PRATICA PROFISSIONAL & 0 & 2 & 2 & 30 & Optativa \\
\hline Optativa & 143090 - PRODUCAO GRAFICA & 1 & 3 & 4 & 60 & Optativa \\
\hline Optativa & 154857 - PROG VISUAL APL ARQ E URB & 2 & 4 & 6 & 90 & Optativa \\
\hline Optativa & 154334 - PROGRAMACAO CONT DE PROJ OBRA & 2 & 2 & 4 & 60 & Optativa \\
\hline Optativa & 155551 - PROJ ARQ INTERES COMUNITÁRIO & 0 & 4 & 4 & 60 & Optativa \\
\hline Optativa & 154261 - PROJ ARQ-PROBL ESPECIAIS & 0 & 6 & 6 & 90 & Optativa \\
\hline Optativa & 154831 - PROJ DE ARQ ASSIST COMPUTADOR & 2 & 2 & 4 & 60 & Optativa \\
\hline Optativa & 154539 - PROJ DE ARQ INDUSTRIALIZADA & 2 & 6 & 8 & 120 & Optativa \\
\hline Optativa & 155489 - PROJ PLAN DE HAB POPULAR & 2 & 2 & 4 & 60 & Optativa \\
\hline Optativa & 155152 - PROJ URB-PROBL ESPECIAIS & 0 & 6 & 6 & 90 & Optativa \\
\hline
\end{tabular}




\begin{tabular}{|c|c|c|c|c|c|c|}
\hline Período & Nome & $\begin{array}{l}\text { Créd. } \\
\text { Aula } \\
\text { teórica }\end{array}$ & $\begin{array}{c}\text { Créd. } \\
\text { Aula } \\
\text { prática }\end{array}$ & $\begin{array}{c}\text { Total } \\
\text { créditos } \\
\text { (teoria, } \\
\text { prática, } \\
\text { extensão } \\
\text { e estudo } \\
\text { pelo } \\
\text { aluno) } \\
\end{array}$ & $\mathrm{CH}$ & O/E \\
\hline Optativa & 155543 - PROJETO AMBIENTAL INTEGRADO & 2 & 2 & 4 & 60 & Optativa \\
\hline Optativa & 154873 - PROJETO PAISAGISTICO 2 & 2 & 4 & 6 & 90 & Optativa \\
\hline Optativa & 125130 - PSICOLOGIA AMBIENTAL & 4 & 0 & 4 & 60 & Optativa \\
\hline Optativa & 114014 - QUIMICA GERAL & 4 & 2 & 6 & 90 & Optativa \\
\hline Optativa & 145432 - REALIDADE BRASILEIRA & 4 & 0 & 4 & 60 & Optativa \\
\hline Optativa & 155420 - SABER LOCAL - COMUNID E ARQUIT & 2 & 2 & 4 & 60 & Optativa \\
\hline Optativa & 155471 - SEMIÓTICA DA CULTURA & 2 & 2 & 4 & 60 & Optativa \\
\hline Optativa & 138240 - SENSORES REMOTOS & 3 & 1 & 4 & 60 & Optativa \\
\hline Optativa & 155306 - SINTAXE URBANA & 2 & 2 & 4 & 60 & Optativa \\
\hline Optativa & 155357 - SISTEMAS CONSTRUTIVOS 2 & 2 & 2 & 4 & 60 & Optativa \\
\hline Optativa & 134988 - SOCIOLOGIA URBANA & 4 & 0 & 4 & 60 & Optativa \\
\hline Optativa & 137499 - TEORIA DA CIENCIA & 4 & 0 & 4 & 60 & Optativa \\
\hline Optativa & 134473 - TEORIA SOCIOLOGICA 1 & 4 & 2 & 6 & 90 & Optativa \\
\hline Optativa & 155179 - TEORIA URBANO-REGIONAL & 2 & 2 & 4 & 60 & Optativa \\
\hline Optativa & 145017 - TEORIAS DA COMUNICACAO 1 & 4 & 0 & 4 & 60 & Optativa \\
\hline Optativa & 155497 - TEORIAS ESTÉTICAS & 2 & 2 & 4 & 60 & Optativa \\
\hline Optativa & 155624 - URB E URBANIZAÇÃO NO BRASIL & 4 & 0 & 4 & 60 & Optativa \\
\hline Optativa & 154903 - VEGETACAO APLIC AO PAISAGISMO & 2 & 2 & 4 & 60 & Optativa \\
\hline Optativa & 123005 - VEGETACAO DO CERRADO & 2 & 2 & 4 & 60 & Optativa \\
\hline
\end{tabular}


APÊNDICES 
APÊNDICE 01: NOTAS FINAIS DE CADA ESCOLA PARA O "ENADESUSTENTABILIDADE” 
Nota do Nota final ENADE- do ENADE-

SUSTENTA- SUSTENTABILIDADE BILIDADE (0-100)

\section{Conceito \\ Número} ENADESUSTENTABILIDADE

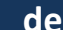

ingressos

no curso em 2007

\begin{tabular}{|c|c|c|c|c|c|}
\hline & $\begin{array}{c}\text { Número } \\
\text { de }\end{array}$ & & $\begin{array}{c}\text { Número } \\
\text { de } \\
\text { alunos }\end{array}$ & \\
Evasão & ingressos & Amostra & que & Permanece & \\
máxima & no início & mínima & fizeram & na & Posição \\
considerada & do curso & (a) & 0 & amostra? & final \\
& subtraindo & & ENADE & (b>=a) & \\
& a evasão & & 2011 & & \\
& & & &
\end{tabular}

322_UNIVERSIDADE PAULISTA_SANTANA DE PARNAÍBA

322_UNIVERSIDADE PAULISTA_SOROCABA 570_ UNIVERSIDADE FEDERAL DO RIO GRANDE DO NORTE_NATAL

1351_INSTITUTO SUPERIOR TUPY -

IST_JOINVILLE

581_ UNIVERSIDADE FEDERAL DO RIO GRANDE DO SUL_PORTO ALEGRE

322_UNIVERSIDADE PAULISTA_BRASÍLIA 56_ UNIVERSIDADE ESTADUAL PAULISTA JÚLIO DE MESQUITA FILHO BAURU 583_UNIVERSIDADE FEDERAL DO

CEARÁ_FORTALEZA

1120 INSTITUTO FEDERAL DE EDUCAÇÃO, CIÊNCIA E TECNOLOGIA FLUMINENSE_CAMPOS DOS GOYTACAZES

1041_CENTRO UNIVERSITÁRIO

UNIVATES_LAJEADO

673 CENTRO UNIVERSITÁRIO DA GRANDE

DOURADOS_DOURADOS

449 UNIVERSIDADE LUTERANA DO

BRASIL_TORRES

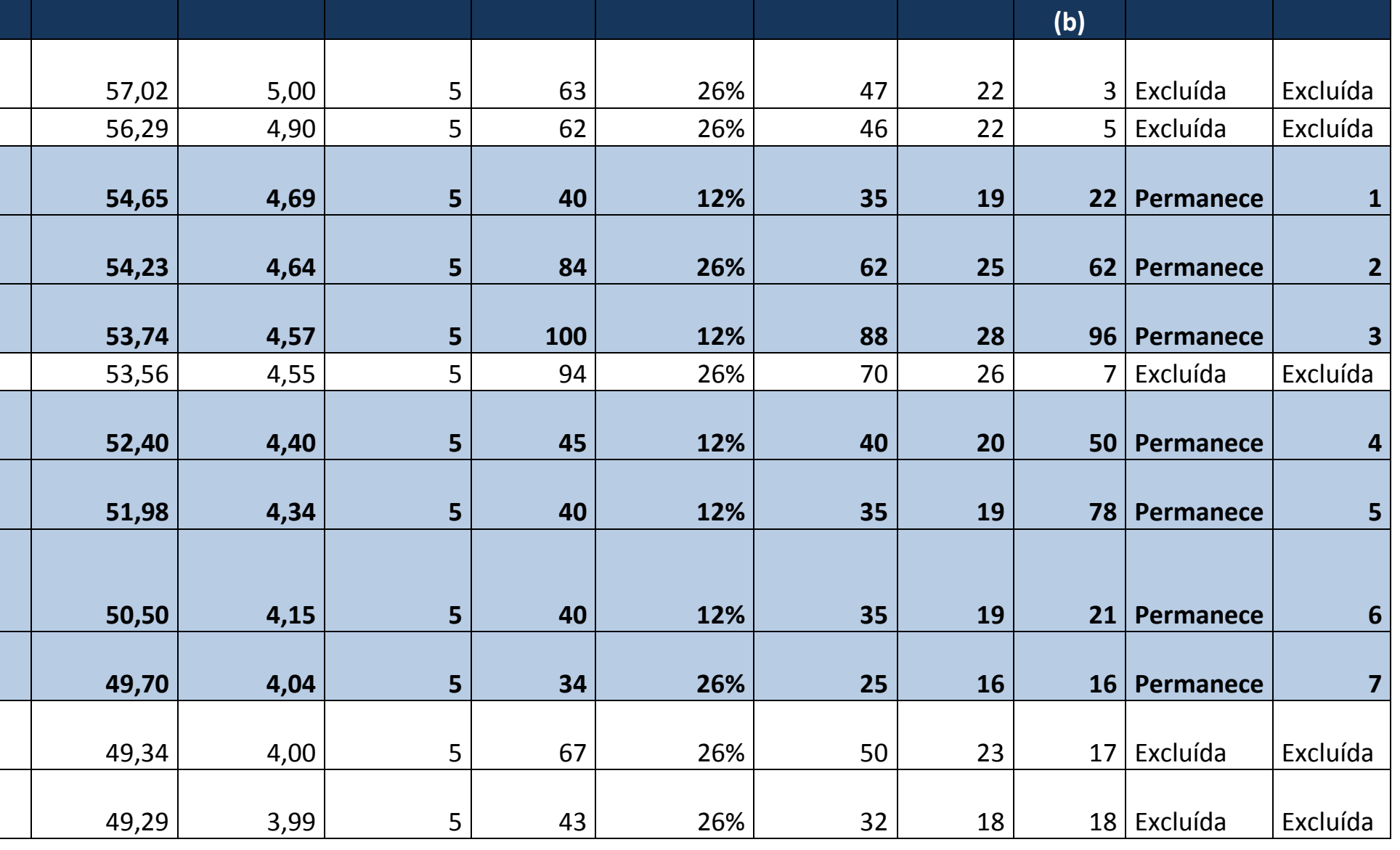


Nota do Nota final

ENADE- do ENADE-

SUSTENTA- SUSTENTA-

BILIDADE BILIDADE

(0-100)
(0-5)

\section{Conceito Número}

ENADE-

SUSTENTA-

BILIDADE

\section{de}

ingressos

no curso em 2007

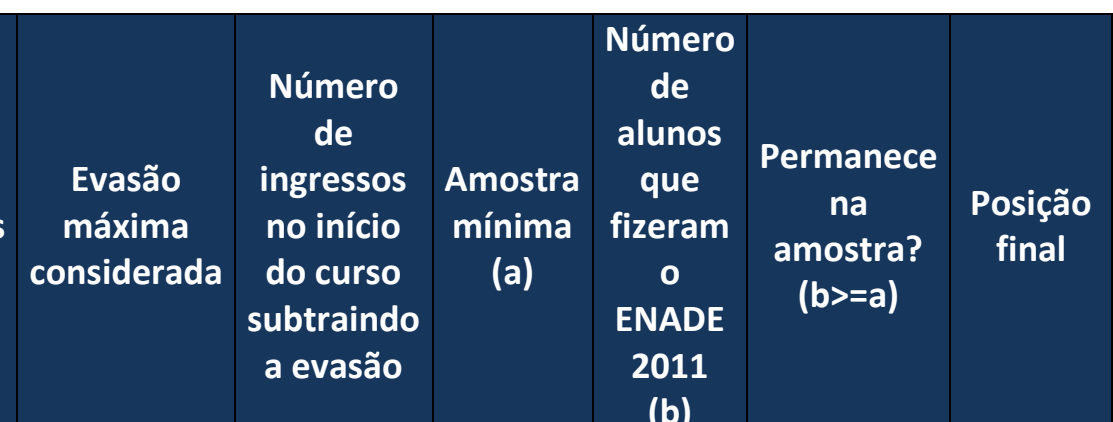

322_UNIVERSIDADE PAULISTA_SÃO PAULO

17_ UNIVERSIDADE FEDERAL DE

UBERLÂNDIA_UBERLÂNDIA

9_ UNIVERSIDADE ESTADUAL DE

\section{LONDRINA LONDRINA}

355_ UNIVERSIDADE TUIUTI DO

PARANÁ_CURITIBA

576_ UNIVERSIDADE FEDERAL DE JUIZ DE

FORA_JUIZ DE FORA

2005_FACULDADE DE CIÊNCIAS SOCIAIS

APLICADAS DE SINOP_SINOP

665_UNIVERSIDADE DE TAUBATÉ_TAUBATÉ

1270_CENTRO UNIVERSITÁRIO DO INSTITUTO DE

ENSIÑO SUPERIOR COC_RIBEIRÃO PRETO

2 UNIVERSIDADE DE BRASÍLIA BRASÍLIA

322_UNIVERSIDADE PAULISTA_SÃO JOSÉ DOS

CAMPOS

1149 CENTRO UNIVERSITÁRIO NOSSA SENHORA DO PATROCÍNIO_SALTO

13_ UNIVERSIDADE DE CAXIAS DO SUL_CAXIAS

DO SUL

295_ UNIVERSIDADE DE SANTA CRUZ DO

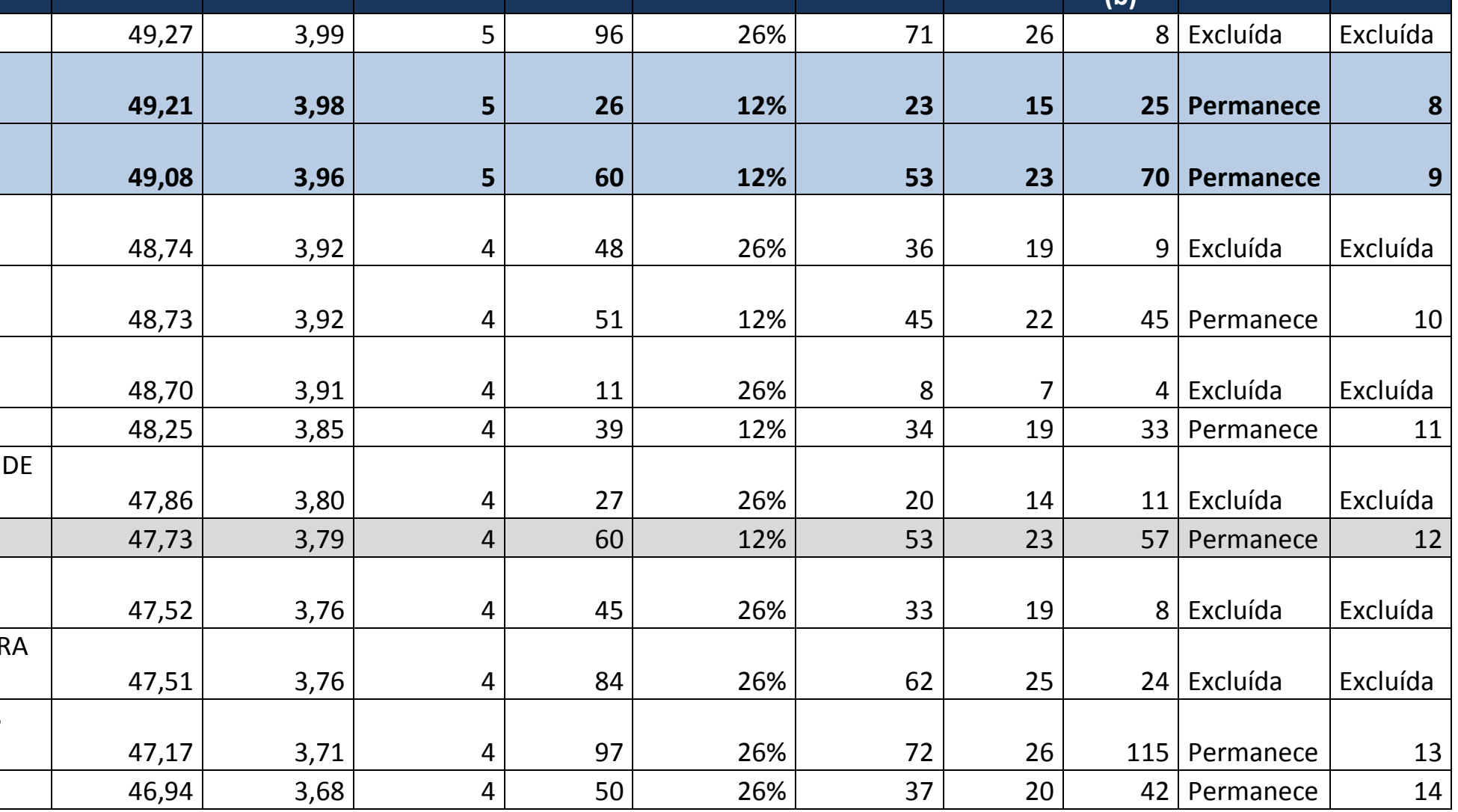


ENADE- do ENADE-

SUSTENTA- SUSTENTA-

BILIDADE BILIDADE

(0-100)

\section{Conceito Número}

ENADE-

SUSTENTA-

BILIDADE

\section{de}

ingressos

no curso em 2007

\begin{tabular}{|c|c|c|c|c|c|}
\hline $\begin{array}{c}\text { Evasão } \\
\text { máxima } \\
\text { considerada }\end{array}$ & $\begin{array}{c}\text { Número } \\
\text { de } \\
\text { ingressos } \\
\text { no início } \\
\text { do curso } \\
\text { subtraindo } \\
\text { a evasão }\end{array}$ & $\begin{array}{c}\text { Amostra } \\
\text { mínima } \\
\text { (a) }\end{array}$ & $\begin{array}{l}\text { Número } \\
\text { de } \\
\text { alunos } \\
\text { que } \\
\text { fizeram } \\
0 \\
\text { ENADE } \\
2011 \\
\text { (b) }\end{array}$ & $\begin{array}{c}\text { Permanece } \\
\text { na } \\
\text { amostra? } \\
(b>=a)\end{array}$ & $\begin{array}{c}\text { Posição } \\
\text { final }\end{array}$ \\
\hline
\end{tabular}

SUL_SANTA CRUZ DO SUL

634_UNIVERSIDADE FEDERAL DE

PELOTAS_PELOTAS

789_UNIVERSIDADE FEDERAL DE RORAIMA_BOA

VISTA

575_ UNIVERSIDADE FEDERAL DE MINAS

GERAIS_BELO HORIZONTE

337_CENTRO DE ENSINO SUPERIOR DE JUIZ DE

FORA_JUIZ DE FORA

8_ UNIVERSIDADE FEDERAL DE VIÇOSA_VIÇOSA 20_UNIVERSIDADE DE PASSO FUNDO_PASSO

FUNDO

349_CENTRO UNIVERSITÁRIO DE BELO

HORIZONTE_BELO HORIZONTE

569_ UNIVERSIDADE FEDERAL DO PARÁ_BELÉM

555_UNIVERSIDADE DE FORTALEZA FORTALEZA

57_ UNIVERSIDADE ESTADUAL DE

MARINGÁ MARINGÁ

579_UNIVERSIDADE FEDERAL DA PARAÍBA_JOÃO

PESSOA

344_CENTRO UNIVERSITÁRIO UNA_BELO

HORIZONTE

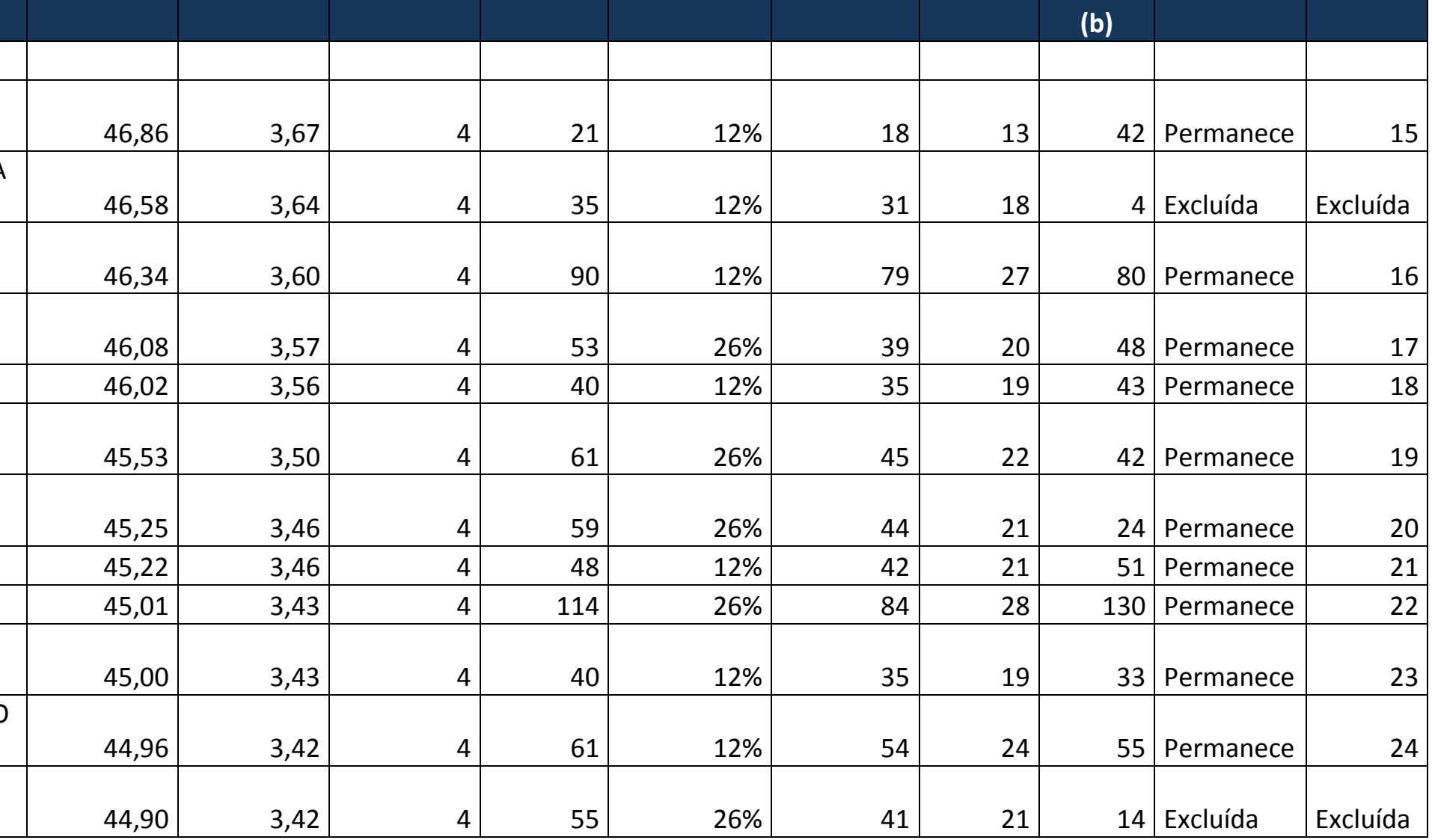




\begin{tabular}{|c|c|c|c|c|c|c|c|c|c|c|}
\hline Instituição de ensino & $\begin{array}{l}\text { Nota do } \\
\text { ENADE- } \\
\text { SUSTENTA- } \\
\text { BILIDADE } \\
(0-100)\end{array}$ & $\begin{array}{l}\text { Nota final } \\
\text { do ENADE- } \\
\text { SUSTENTA- } \\
\text { BILIDADE } \\
(0-5)\end{array}$ & $\begin{array}{l}\text { Conceito } \\
\text { ENADE- } \\
\text { SUSTENTA- } \\
\text { BILIDADE }\end{array}$ & $\begin{array}{l}\text { Número } \\
\text { de } \\
\text { ingressos } \\
\text { no curso } \\
\text { em } 2007\end{array}$ & $\begin{array}{c}\text { Evasão } \\
\text { máxima } \\
\text { considerada }\end{array}$ & $\begin{array}{l}\text { Número } \\
\text { de } \\
\text { ingressos } \\
\text { no início } \\
\text { do curso } \\
\text { subtraindo } \\
\text { a evasão }\end{array}$ & $\begin{array}{c}\text { Amostra } \\
\text { mínima } \\
\text { (a) }\end{array}$ & $\begin{array}{l}\text { Número } \\
\text { de } \\
\text { alunos } \\
\text { que } \\
\text { fizeram } \\
\text { o } \\
\text { ENADE } \\
2011 \\
\text { (b) }\end{array}$ & $\begin{array}{c}\text { Permanece } \\
\text { na } \\
\text { amostra? } \\
\text { (b>=a) }\end{array}$ & $\begin{array}{l}\text { Posição } \\
\text { final }\end{array}$ \\
\hline $\begin{array}{l}\text { 1_UNIVERSIDADE FEDERAL DE MATO } \\
\text { GROSSO_CUIABÁ }\end{array}$ & 44,75 & 3,40 & 4 & 30 & $12 \%$ & 26 & 16 & 75 & Permanece & 25 \\
\hline $\begin{array}{l}\text { 76_UNIVERSIDADE REGIONAL DE } \\
\text { BLUMENAU_BLUMENAU }\end{array}$ & 44,69 & 3,39 & 4 & 70 & $12 \%$ & 62 & 25 & 50 & Permanece & 26 \\
\hline $\begin{array}{l}\text { 571_UNIVERSIDADE FEDERAL DO } \\
\text { PARANÁ_CURITIBA }\end{array}$ & 44,68 & 3,39 & 4 & 44 & $12 \%$ & 39 & 20 & 24 & Permanece & 27 \\
\hline $\begin{array}{l}\text { 694_UNIVERSIDADE FEDERAL DE MATO GROSSO } \\
\text { DO SUL_CAMPO GRANDE }\end{array}$ & 44,59 & 3,37 & 4 & 39 & $12 \%$ & 34 & 19 & 36 & Permanece & 28 \\
\hline $\begin{array}{l}\text { 1187_CENTRO UNIVERSITÁRIO } \\
\text { MÓDULO_CARAGUATATUBA }\end{array}$ & 44,58 & 3,37 & 4 & 55 & $26 \%$ & 41 & 21 & 25 & Permanece & 29 \\
\hline $\begin{array}{l}\text { 645_CENTRO UNIVERSITÁRIO DE JARAGUÁ DO } \\
\text { SUL_JARAGUÁ DO SUL }\end{array}$ & 44,57 & 3,37 & 4 & 22 & $26 \%$ & 16 & 12 & 20 & Permanece & 30 \\
\hline $\begin{array}{l}\text { 585_UNIVERSIDADE FEDERAL DE SANTA } \\
\text { CATARINA_FLORIANÓPOLIS }\end{array}$ & 44,51 & 3,37 & 4 & 80 & $12 \%$ & 70 & 26 & 103 & Permanece & 31 \\
\hline $\begin{array}{l}\text { 83_UNIVERSIDADE DO VALE DO } \\
\text { ITAJAII_BALNEÁRIO CAMBORIÚ }\end{array}$ & 44,34 & 3,34 & 4 & 79 & $26 \%$ & 58 & 24 & 79 & Permanece & 32 \\
\hline $\begin{array}{l}\text { 494_UNIVERSIDADE DO SUL DE SANTA } \\
\text { CATARINA_TUBARÃO }\end{array}$ & 44,06 & 3,31 & 4 & 37 & $26 \%$ & 27 & 17 & 32 & Permanece & 33 \\
\hline $\begin{array}{l}\text { 1196_CENTRO UNIVERSITÁRIO DE MARINGÁ - } \\
\text { CEUMAR_MARINGÁ }\end{array}$ & 44,02 & 3,30 & 4 & 60 & $26 \%$ & 44 & 22 & 47 & Permanece & 34 \\
\hline $\begin{array}{l}\text { 54_UNIVERSIDADE ESTADUAL DE } \\
\text { CAMPINAS_CAMPINAS }\end{array}$ & 43,94 & 3,29 & 4 & 32 & $12 \%$ & 28 & 17 & 38 & Permanece & 35 \\
\hline 203_UNIVERSIDADE SÃO JUDAS TADEU_SÃO & 43,87 & 3,28 & 4 & 141 & $26 \%$ & 104 & 30 & 56 & Permanece & 36 \\
\hline
\end{tabular}




\begin{tabular}{|c|c|c|c|c|c|c|c|c|c|c|}
\hline Instituição de ensino & $\begin{array}{l}\text { Nota do } \\
\text { ENADE- } \\
\text { SUSTENTA- } \\
\text { BILIDADE } \\
(0-100)\end{array}$ & \begin{tabular}{|c|} 
Nota final \\
do ENADE- \\
SUSTENTA- \\
BILIDADE \\
$(0-5)$
\end{tabular} & $\begin{array}{l}\text { Conceito } \\
\text { ENADE- } \\
\text { SUSTENTA- } \\
\text { BILIDADE }\end{array}$ & $\begin{array}{l}\text { Número } \\
\text { de } \\
\text { ingressos } \\
\text { no curso } \\
\text { em } 2007\end{array}$ & $\begin{array}{c}\text { Evasão } \\
\text { máxima } \\
\text { considerada }\end{array}$ & $\begin{array}{l}\text { Número } \\
\text { de } \\
\text { ingressos } \\
\text { no início } \\
\text { do curso } \\
\text { subtraindo } \\
\text { a evasão }\end{array}$ & $\begin{array}{c}\text { Amostra } \\
\text { mínima } \\
\text { (a) }\end{array}$ & $\begin{array}{l}\text { Número } \\
\text { de } \\
\text { alunos } \\
\text { que } \\
\text { fizeram } \\
\text { o } \\
\text { ENADE } \\
2011 \\
\text { (b) }\end{array}$ & $\begin{array}{c}\text { Permanece } \\
\text { na } \\
\text { amostra? } \\
\text { (b>=a) }\end{array}$ & $\begin{array}{l}\text { Posição } \\
\text { final }\end{array}$ \\
\hline PAULO & & & & & & & & & & \\
\hline 1128_UNIVERSIDADE DE ITAÚNA_ITAÚNA & 43,59 & 3,25 & 4 & 41 & $26 \%$ & 30 & 18 & 34 & Permanece & 37 \\
\hline $\begin{array}{l}\text { 271_UNIVERSIDADE DO OESTE } \\
\text { PAULISTA_PRESIDENTE PRUDENTE }\end{array}$ & 43,38 & 3,22 & 4 & 42 & $26 \%$ & 31 & 18 & 24 & Permanece & 38 \\
\hline $\begin{array}{l}\text { 21_PONTIFÍCIA UNIVERSIDADE CATÓLICA DO RIO } \\
\text { GRANDE DO SUL_PORTO ALEGRE }\end{array}$ & 43,28 & 3,20 & 4 & 99 & $26 \%$ & 73 & 27 & 103 & Permanece & 39 \\
\hline 322_UNIVERSIDADE PAULISTA_CAMPINAS & 43,22 & 3,20 & 4 & 96 & $26 \%$ & 71 & 26 & 10 & Excluída & Excluída \\
\hline $\begin{array}{l}\text { 482_UNIVERSIDADE DO EXTREMO SUL } \\
\text { CATARINENSE_CRICIÚMA }\end{array}$ & 43,18 & 3,19 & 4 & 61 & $26 \%$ & 45 & 22 & 43 & Permanece & 40 \\
\hline $\begin{array}{l}\text { 448_CENTRO UNIVERSITÁRIO RITTER DOS } \\
\text { REIS_PORTO ALEGRE }\end{array}$ & 43,03 & 3,17 & 4 & 125 & $26 \%$ & 93 & 29 & 96 & Permanece & 41 \\
\hline 23_UNIVERSIDADE FEEVALE_NOVO HAMBURGO & 42,84 & 3,15 & 4 & 58 & $26 \%$ & 43 & 21 & 43 & Permanece & 42 \\
\hline $\begin{array}{l}\text { 513_UNIVERSIDADE VALE DO RIO } \\
\text { DOCE_GOVERNADOR VALADARES }\end{array}$ & 42,73 & 3,13 & 4 & 22 & $26 \%$ & 16 & 12 & 5 & Excluída & Excluída \\
\hline $\begin{array}{l}\text { 338_PONTIFÍCIA UNIVERSIDADE CATÓLICA DE } \\
\text { MINAS GERAIS_POÇOS DE CALDAS }\end{array}$ & 42,63 & 3,12 & 4 & 53 & $26 \%$ & 39 & 20 & 37 & Permanece & 43 \\
\hline 670_UNIVERSIDADE SÃO FRANCISCO_ITATIBA & 42,52 & 3,10 & 4 & 51 & $26 \%$ & 38 & 20 & 84 & Permanece & 44 \\
\hline $\begin{array}{l}528 \text { PONTIFÍCIA UNIVERSIDADE CATÓLICA DO } \\
\text { RIO DE JANEIRO_RIO DE JANEIRO }\end{array}$ & 42,45 & 3,10 & 4 & 83 & $26 \%$ & 61 & 25 & 74 & Permanece & 45 \\
\hline $\begin{array}{l}\text { 3151_UNIVERSIDADE COMUNITÁRIA DA REGIÃO } \\
\text { DE CHAPECÓ_CHAPECÓ }\end{array}$ & 42,38 & 3,09 & 4 & 84 & $12 \%$ & 74 & 27 & 68 & Permanece & 46 \\
\hline 222_CENTRO UNIVERSITÁRIO DE & 42,30 & 3,08 & 4 & 29 & $26 \%$ & 21 & 14 & 18 & Permanece & 47 \\
\hline
\end{tabular}


Nota do Nota final ENADE- do ENADESUSTENTA- SUSTENTABILIDADE BILIDADE (0-100)

\section{Conceito Número} ENADE-

SUSTENTA BILIDADE

\section{de}

ingressos

no curso em 2007
Número

de

de

Evasão

máxima

considerada

no início

do curso

subtraindo

a evasão alunos

Amostra que

mínima fizeram

(a)

o

ENADE

2011

(b)

VOTUPORANGA_VOTUPORANGA

322_UNIVERSIDADE PAULISTA_BAURU

5 UNIVERSIDADE FEDERAL DO PIAUII TERESINA 56_UNIVERSIDADE ESTADUAL PAULISTA JÚLIO DE MESQUITA FILHO_PRESIDENTE PRUDENTE 578 UNIVERSIDADE FEDERAL DA

BAHIA_SALVADOR

3631 FACULDADE DAMAS DA INSTRUÇÃO CRISTÃ_RECIFE

568 UNIVERSIDADE ESTADUAL DO

MARANHÃO_SÃO LUÍS

322_UNIVERSIDADE PAULISTA_SÃO JOSÉ DO RIO PRETO

719_UNIVERSIDADE DO ESTADO DE MATO GROSSO BARRA DO BUGRES

207_CENTRO UNIVERSITÁRIO MOURA

LACERDA_RIBEIRÃO PRETO

582 UNIVERSIDADE FEDERAL DE SANTA

MARIA SANTA MARIA

15452_FACULDADE PRESIDENTE ANTÔNIO

CARLOS DE BOM DESPACHO_BOM DESPACHO

47_ UNIVERSIDADE ESTADUAL DE

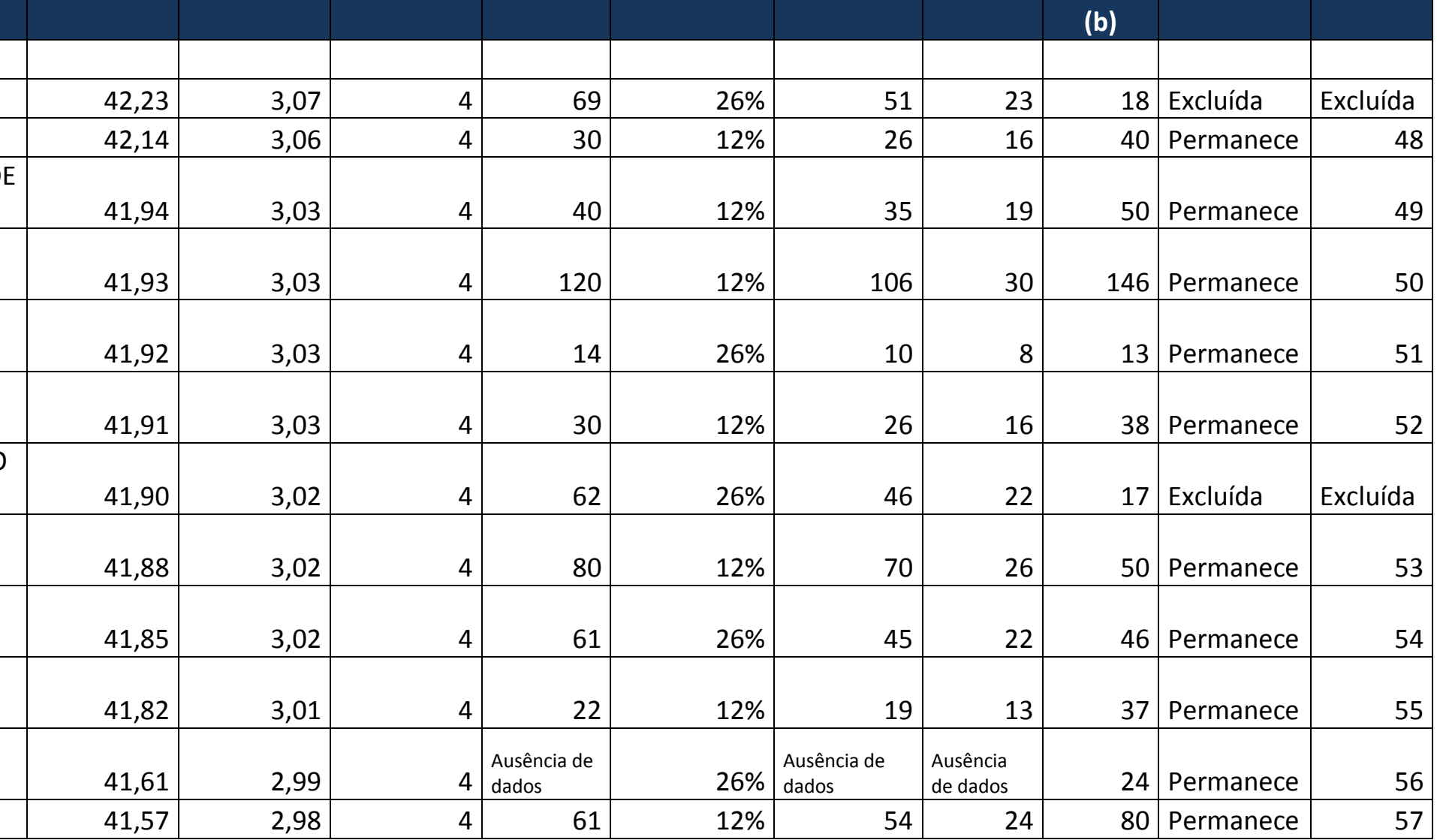




\begin{tabular}{|c|c|c|c|c|c|c|c|c|c|c|}
\hline Instituição de ensino & $\begin{array}{l}\text { Nota do } \\
\text { ENADE- } \\
\text { SUSTENTA- } \\
\text { BILIDADE } \\
(0-100)\end{array}$ & $\begin{array}{l}\text { Nota final } \\
\text { do ENADE- } \\
\text { SUSTENTA- } \\
\text { BILIDADE } \\
(0-5)\end{array}$ & $\begin{array}{l}\text { Conceito } \\
\text { ENADE- } \\
\text { SUSTENTA- } \\
\text { BILIDADE }\end{array}$ & $\begin{array}{l}\begin{array}{c}\text { Número } \\
\text { de }\end{array} \\
\text { ingressos } \\
\text { no curso } \\
\text { em } 2007\end{array}$ & $\begin{array}{c}\text { Evasão } \\
\text { máxima } \\
\text { considerada }\end{array}$ & $\begin{array}{l}\text { Número } \\
\text { de } \\
\text { ingressos } \\
\text { no início } \\
\text { do curso } \\
\text { subtraindo } \\
\text { a evasão }\end{array}$ & $\begin{array}{c}\text { Amostra } \\
\text { mínima } \\
\text { (a) }\end{array}$ & $\begin{array}{l}\text { Número } \\
\text { de } \\
\text { alunos } \\
\text { que } \\
\text { fizeram } \\
\text { o } \\
\text { ENADE } \\
2011 \\
\text { (b) }\end{array}$ & $\begin{array}{c}\text { Permanece } \\
\text { na } \\
\text { amostra? } \\
\text { (b>=a) }\end{array}$ & $\begin{array}{c}\text { Posição } \\
\text { final }\end{array}$ \\
\hline \multicolumn{11}{|l|}{ GOIÁS_ANÁPOLIS } \\
\hline $\begin{array}{l}\text { 430_CENTRO UNIVERSITÁRIO } \\
\text { FILADÉLFIA_LONDRINA }\end{array}$ & 41,54 & 2,98 & 4 & 61 & $26 \%$ & 45 & 22 & 66 & Permanece & 58 \\
\hline $\begin{array}{l}\text { 1775_FACULDAADE DO VALE DO } \\
\text { IPOJUCA_CARUARU }\end{array}$ & 41,51 & 2,97 & 4 & 58 & $26 \%$ & 43 & 21 & 27 & Permanece & 59 \\
\hline $\begin{array}{l}\text { 861_CENTRO DE ENSINO SUPERIOR DO } \\
\text { AMAPÁ_MACAPÁ }\end{array}$ & 41,45 & 2,96 & 4 & 86 & $26 \%$ & 64 & 25 & 27 & Permanece & 60 \\
\hline $\begin{array}{l}\text { 586_UNIVERSIDADE FEDERAL DO RIO DE } \\
\text { JANEIRO_RIO DE JANEIRO }\end{array}$ & 41,34 & 2,95 & 4 & 239 & $12 \%$ & 210 & 35 & 157 & Permanece & 61 \\
\hline $\begin{array}{l}\text { 3753_FACULDADES INTEGRADAS DOM PEDRO } \\
\text { II_SÃO JOSÉ DO RIO PRETO }\end{array}$ & 40,75 & 2,87 & 3 & 27 & $26 \%$ & 20 & 14 & 16 & Permanece & 62 \\
\hline $\begin{array}{l}426 \_ \text {CENTRO UNIVERSITÁRIO } \\
\text { FRANCISCANO_SANTA MARIA }\end{array}$ & 40,55 & 2,85 & 3 & 40 & $26 \%$ & 30 & 17 & 37 & Permanece & 63 \\
\hline $\begin{array}{l}\text { 19_PONTIFÍCIA UNIVERSIDADE CATÓLICA DE } \\
\text { CAMPINAS_CAMPINAS }\end{array}$ & 40,09 & 2,79 & 3 & 152 & $26 \%$ & 112 & 30 & 115 & Permanece & 64 \\
\hline $\begin{array}{l}\text { 10_PONTIFÍCIA UNIVERSIDADE CATÓLICA DO } \\
\text { PARANÁ_CURITIBA }\end{array}$ & 40,07 & 2,78 & 3 & 192 & $26 \%$ & 142 & 32 & 123 & Permanece & 65 \\
\hline $\begin{array}{l}\text { 18_UNIVERSIDADE CATÓLICA DE } \\
\text { PELOTAS_PELOTAS }\end{array}$ & 39,69 & 2,73 & 3 & 25 & $26 \%$ & 19 & 13 & 25 & Permanece & 66 \\
\hline $\begin{array}{l}\text { 527_PONTIFÍCIA UNIVERSIDADE CATÓLICA DE } \\
\text { GOIÁS_GOIÂNIA }\end{array}$ & 39,57 & 2,72 & 3 & 95 & $26 \%$ & 70 & 26 & 140 & Permanece & 67 \\
\hline $\begin{array}{l}\text { 452_CENTRO UNIVERSITÁRIO LUTERANO DE } \\
\text { MANAUS_MANAUS }\end{array}$ & 39,48 & 2,71 & 3 & 36 & $26 \%$ & 27 & 16 & 29 & Permanece & 68 \\
\hline
\end{tabular}


Nota do Nota final

ENADE-

SUSTENTA- SUSTENTA-

BILIDADE BILIDADE

(0-100)

\section{Conceito ENADE- \\ SUSTENTA- BILIDADE}

de

ingressos

no curso em 2007
Número

de

de

Evasão

máxima

considerada

no início

do curso

subtraindo

a evasão alunos

Amostra que

(a)

o

ENADE

2011

(b) mínima fizeram

\begin{tabular}{|c|c|c|c|c|c|c|c|c|c|c|}
\hline 1042_UNIVERSIDADE POSITIVO_CURITIBA & 39,46 & 2,70 & 3 & 99 & $26 \%$ & 73 & 27 & 65 & Permanece & 69 \\
\hline $\begin{array}{l}\text { 878_CENTRO UNIVERSITÁRIO DO LESTE DE } \\
\text { MINAS GERAIS_CORONEL FABRICIANO }\end{array}$ & 39,36 & 2,69 & 3 & 43 & $26 \%$ & 32 & 18 & 40 & Permanece & 70 \\
\hline $\begin{array}{l}\text { 1334_FACULDADE DE CIÊNCIAS SOCIAIS } \\
\text { APLICADAS - FACISA_CAMPINA GRANDE }\end{array}$ & 39,35 & 2,69 & 3 & 53 & $26 \%$ & 39 & 20 & 50 & Permanece & 71 \\
\hline $\begin{array}{l}\text { 3849_FUNDAÇÃO UNIVERSIDADE FEDERAL DO } \\
\text { TOCANTINS_PALMAS }\end{array}$ & 39,18 & 2,67 & 3 & 50 & $12 \%$ & 44 & 21 & 66 & Permanece & 72 \\
\hline $\begin{array}{l}\text { 1396_FACULDADE DINÂMICA DAS } \\
\text { CATARATAS_FOZ DO IGUAÇU }\end{array}$ & 38,99 & 2,64 & 3 & 95 & $26 \%$ & 70 & 26 & 57 & Permanece & 73 \\
\hline $\begin{array}{l}\text { 1828_ESCOLA DA CIDADE - FACULDADE DE } \\
\text { ARQUITETURA E URBANISMO_SÃO PAULO }\end{array}$ & 38,91 & 2,63 & 3 & 57 & $26 \%$ & 42 & 21 & 49 & Permanece & 74 \\
\hline $\begin{array}{l}\text { 82_UNIVERSIDADE DO OESTE DE SANTA } \\
\text { CATARINA_XANXERÊ }\end{array}$ & 38,83 & 2,62 & 3 & 32 & $26 \%$ & 24 & 15 & 29 & Permanece & 75 \\
\hline $\begin{array}{l}\text { 577_UNIVERSIDADE FEDERAL DE } \\
\text { ALAGOAS_MACEIÓ }\end{array}$ & 38,75 & 2,61 & 3 & 61 & $26 \%$ & 45 & 22 & 79 & Permanece & 76 \\
\hline $\begin{array}{l}\text { 1113_CENTRO UNIVERSITÁRIO EURO- } \\
\text { AMERICANO_BRASIILIA }\end{array}$ & 38,63 & 2,60 & 3 & 69 & $26 \%$ & 51 & 23 & 72 & Permanece & 77 \\
\hline 952_UNIVERSIDADE SANTA CECÍLIA_SANTOS & 38,57 & 2,59 & 3 & 56 & $26 \%$ & 41 & 21 & 26 & Permanece & 78 \\
\hline $\begin{array}{l}\text { 494_UNIVERSIDADE DO SUL DE SANTA } \\
\text { CATARINA_FLORIANÓPOLIS }\end{array}$ & 38,53 & 2,58 & 3 & $\begin{array}{l}\text { Ausência de } \\
\text { dados }\end{array}$ & $26 \%$ & $\begin{array}{l}\text { Ausência de } \\
\text { dados }\end{array}$ & $\begin{array}{l}\text { Ausência } \\
\text { de dados }\end{array}$ & 42 & Permanece & 79 \\
\hline $\begin{array}{l}\text { 146_CENTRO UNIVERSITÁRIO DE RIO PRETO_SÃO } \\
\text { JOSÉ DO RIO PRETO }\end{array}$ & 38,48 & 2,58 & 3 & 42 & $26 \%$ & 31 & 18 & 21 & Permanece & 80 \\
\hline
\end{tabular}


Nota do Nota final

ENADE- do ENADE-

SUSTENTA- SUSTENTA-

BILIDADE BILIDADE

(0-100)
Conceito Número

ENADE-

SUSTENTA-

BILIDADE

\section{de}

ingressos

no curso em 2007
Número

de

de

Evasão

máxima

considerada

no início

do curso

subtraindo alunos

Amostra que

mínima fizeram

(a)

o

ENADE

2011

(b)
227_UNIVERSIDADE CATÓLICA DE

SANTOS_SANTOS

2132_FACULDADE BARÃO DO RIO BRANCO_RIO

BRANCO

221_UNIVERSIDADE CRUZEIRO DO SUL_SÃO

PAULO

580 UNIVERSIDADE FEDERAL DE

PERNAMBUCO_RECIFE

798_FACULDADE DE ARACRUZ_ARACRUZ

11 UNIVERSIDADE CATÓLICA DE

PERNAMBUCO_RECIFE

1443_FACULDADE NACIONAL_VITÓRIA

1513 INSTITUTO DE CIÊNCIAS JURÍDICAS E

SOCIAIS PROFESSOR CAMILLO FILHO_TERESINA

671 UNIVERSIDADE ANHANGUERA -

UNIDERP_CAMPO GRANDE

215 UNIVERSIDADE DO GRANDE ABC SANTO

ANDRÉ

402_CENTRO UNIVERSITÁRIO DE

BRASÍLIA BRASÍLIA

14_ UNIVERSIDADE DO VALE DO RIO DOS

SINOS_SÃO LEOPOLDO a evasão

\begin{tabular}{r|r|r|r}
\hline 38,35 & 2,56 & 3 & \\
\hline 38,31 & 2,55 & 3 & \\
\hline 37,95 & 2,51 & 3 &
\end{tabular}

\begin{tabular}{c|c}
$\begin{array}{c}\text { Permanece } \\
\text { na }\end{array}$ & $\begin{array}{c}\text { Posição } \\
\text { amostra? }\end{array}$ \\
\hline final
\end{tabular}

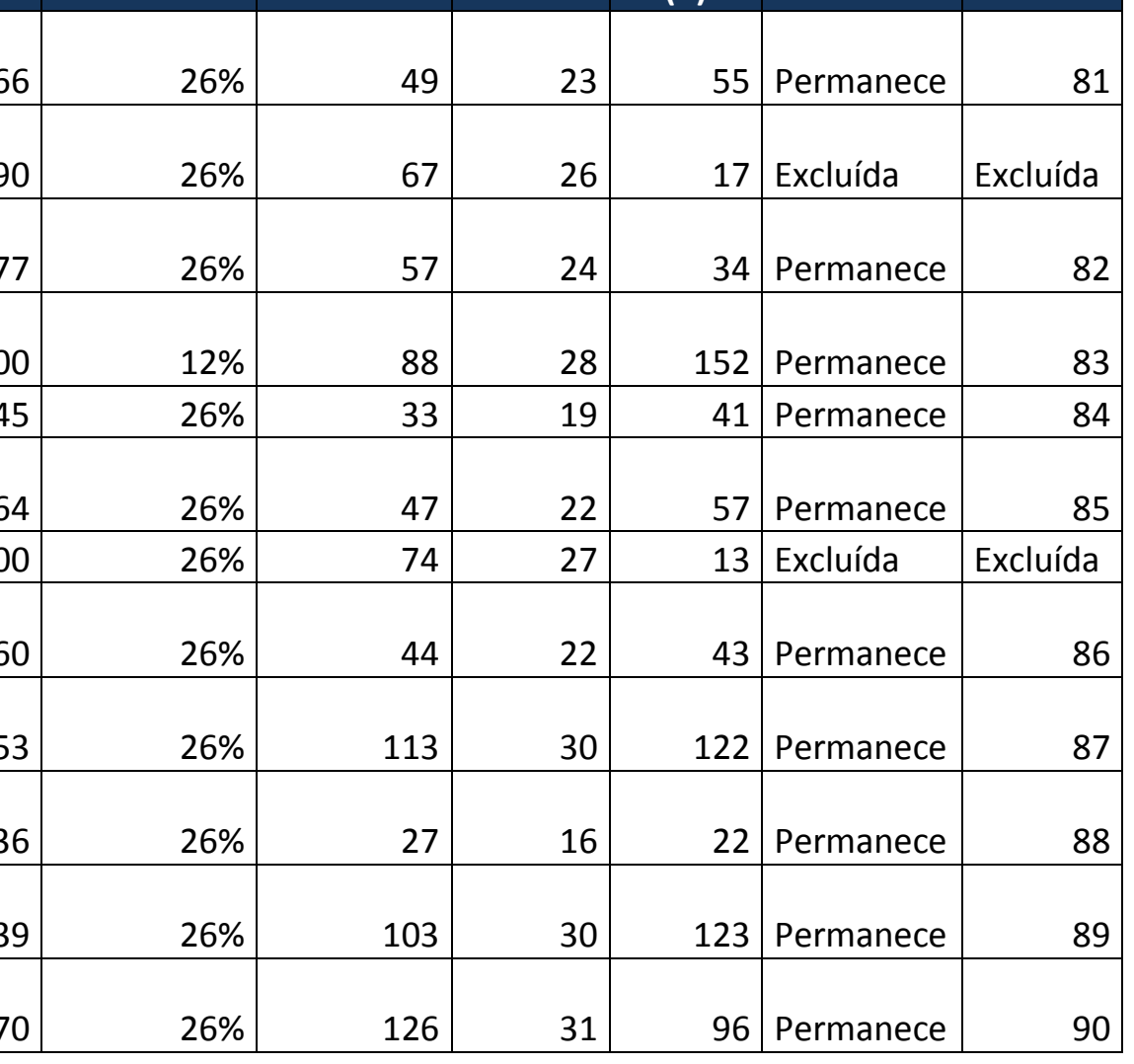




\begin{tabular}{|c|c|c|c|c|c|c|c|c|c|c|}
\hline Instituição de ensino & $\begin{array}{l}\text { Nota do } \\
\text { ENADE- } \\
\text { SUSTENTA- } \\
\text { BILIDADE } \\
(0-100)\end{array}$ & $\begin{array}{l}\text { Nota final } \\
\text { do ENADE- } \\
\text { SUSTENTA- } \\
\text { BILIDADE } \\
(0-5)\end{array}$ & $\begin{array}{l}\text { Conceito } \\
\text { ENADE- } \\
\text { SUSTENTA- } \\
\text { BILIDADE }\end{array}$ & $\begin{array}{l}\text { Número } \\
\text { de } \\
\text { ingressos } \\
\text { no curso } \\
\text { em } 2007\end{array}$ & $\begin{array}{c}\text { Evasão } \\
\text { máxima } \\
\text { considerada }\end{array}$ & $\begin{array}{l}\text { Número } \\
\text { de } \\
\text { ingressos } \\
\text { no início } \\
\text { do curso } \\
\text { subtraindo } \\
\text { a evasão }\end{array}$ & $\begin{array}{c}\text { Amostra } \\
\text { mínima } \\
\text { (a) }\end{array}$ & $\begin{array}{l}\text { Número } \\
\text { de } \\
\text { alunos } \\
\text { que } \\
\text { fizeram } \\
0 \\
\text { ENADE } \\
2011 \\
\text { (b) }\end{array}$ & $\begin{array}{l}\text { Permanece } \\
\text { na } \\
\text { amostra? } \\
(b>=a)\end{array}$ & $\begin{array}{l}\text { Posição } \\
\text { final }\end{array}$ \\
\hline 385_UNIVERSIDADE SALVADOR_SALVADOR & 36,80 & 2,36 & 3 & 132 & $26 \%$ & 98 & 29 & 85 & Permanece & 91 \\
\hline $\begin{array}{l}\text { 457_UNIVERSIDADE BANDEIRANTE DE SÃO } \\
\text { PAULO_SÃO BERNARDO DO CAMPO }\end{array}$ & 36,71 & 2,35 & 3 & 69 & $26 \%$ & 51 & 23 & 30 & Permanece & 92 \\
\hline $\begin{array}{l}\text { 669_CENTRO UNIVERSITÁRIO NILTON } \\
\text { LINS_MANAUS }\end{array}$ & 36,63 & 2,33 & 3 & 50 & $26 \%$ & 37 & 20 & 15 & Excluída & Excluída \\
\hline 780_UNIVERSIDADE DE CUIABÁ_CUIABÁ & 36,52 & 2,32 & 3 & 88 & $26 \%$ & 65 & 25 & 24 & Excluída & Excluída \\
\hline $\begin{array}{l}\text { 574_UNIVERSIDADE FEDERAL RURAL DO RIO DE } \\
\text { JANEIRO_SEROPÉDICA }\end{array}$ & 36,44 & 2,31 & 3 & 30 & $12 \%$ & 26 & 16 & 35 & Permanece & 93 \\
\hline 269_FACULDADE FACCAT_TUPÃ & 36,22 & 2,28 & 3 & 24 & $26 \%$ & 18 & 13 & 18 & Permanece & 94 \\
\hline $\begin{array}{l}\text { 526_UNIVERSIDADE BRAZ CUBAS_MOGI DAS } \\
\text { CRUZES }\end{array}$ & 36,17 & 2,27 & 3 & 30 & $26 \%$ & 22 & 15 & 54 & Permanece & 95 \\
\hline $\begin{array}{l}\text { 521_UNIVERSIDADE DE MOGI DAS } \\
\text { CRUZES_MOGI DAS CRUZES }\end{array}$ & 35,91 & 2,24 & 3 & 51 & $26 \%$ & 38 & 20 & 17 & Excluída & Excluída \\
\hline $\begin{array}{l}\text { 1961_INSTITUTO TECNOLÓGICO E DAS CIÊNCIAS } \\
\text { SOCIAIS APLICADAS E DA SAÚDE DO CENTRO } \\
\text { EDUC. N. SRa AUXILIADORA_CAMPOS DOS } \\
\text { GOYTACAZES }\end{array}$ & 35,79 & 2,23 & 3 & 55 & $26 \%$ & 41 & 21 & 21 & Permanece & 96 \\
\hline 446_UNIVERSIDADE DE CRUZ ALTA_CRUZ ALTA & 35,73 & 2,22 & 3 & 17 & $26 \%$ & 13 & 10 & 24 & Permanece & 97 \\
\hline $\begin{array}{l}\text { 1542_CENTRO UNIVERSITÁRIO GERALDO DI } \\
\text { BIASE_VOLTA REDONDA }\end{array}$ & 35,69 & 2,21 & 3 & 83 & $26 \%$ & 61 & 25 & 41 & Permanece & 98 \\
\hline 437_UNIVERSIDADE PARANAENSE_UMUARAMA & 35,64 & 2,20 & 3 & 51 & $26 \%$ & 38 & 20 & 47 & Permanece & 99 \\
\hline 2037_FACULDADE UNIME DE CIÊNCIAS EXATAS E & 35,49 & 2,19 & 3 & 111 & $26 \%$ & 82 & 28 & 96 & Permanece & 100 \\
\hline
\end{tabular}




\begin{tabular}{|c|c|c|c|c|c|c|c|c|c|c|}
\hline Instituição de ensino & $\begin{array}{l}\text { Nota do } \\
\text { ENADE- } \\
\text { SUSTENTA- } \\
\text { BILIDADE } \\
(0-100)\end{array}$ & $\begin{array}{l}\text { Nota final } \\
\text { do ENADE- } \\
\text { SUSTENTA- } \\
\text { BILIDADE } \\
(0-5)\end{array}$ & $\begin{array}{l}\text { Conceito } \\
\text { ENADE- } \\
\text { SUSTENTA- } \\
\text { BILIDADE }\end{array}$ & $\begin{array}{l}\text { Número } \\
\text { de } \\
\text { ingressos } \\
\text { no curso } \\
\text { em } 2007\end{array}$ & $\begin{array}{l}\text { Evasão } \\
\text { máxima } \\
\text { considerada }\end{array}$ & $\begin{array}{l}\text { Número } \\
\text { de } \\
\text { ingressos } \\
\text { no início } \\
\text { do curso } \\
\text { subtraindo } \\
\text { a evasão }\end{array}$ & $\begin{array}{c}\text { Amostra } \\
\text { mínima } \\
\text { (a) }\end{array}$ & $\begin{array}{l}\text { Número } \\
\text { de } \\
\text { alunos } \\
\text { que } \\
\text { fizeram } \\
\text { o } \\
\text { ENADE } \\
2011 \\
\text { (b) }\end{array}$ & $\begin{array}{c}\text { Permanece } \\
\text { na } \\
\text { amostra? } \\
\text { (b>=a) }\end{array}$ & $\begin{array}{l}\text { Posição } \\
\text { final }\end{array}$ \\
\hline \multicolumn{11}{|l|}{ TECNOLÓGICAS_LAURO DE FREITAS } \\
\hline $\begin{array}{l}\text { 296_UNIVERSIDADE DA REGIÃO DA } \\
\text { CAMPANHA_BAGÉ }\end{array}$ & 35,31 & 2,16 & 3 & 20 & $26 \%$ & 15 & 11 & 12 & Permanece & 101 \\
\hline $\begin{array}{l}\text { 138_CENTRO UNIVERSITÁRIO BARÃO DE } \\
\text { MAUÁ_RIBEIRÃO PRETO }\end{array}$ & 35,26 & 2,16 & 3 & 41 & $26 \%$ & 30 & 18 & 29 & Permanece & 102 \\
\hline $\begin{array}{l}\text { 449_UNIVERSIDADE LUTERANA DO } \\
\text { BRASIL_CANOAS }\end{array}$ & 35,22 & 2,15 & 3 & 59 & $26 \%$ & 44 & 21 & 43 & Permanece & 103 \\
\hline $\begin{array}{l}275 \text { _ UNIVERSIDADE DO VALE DO PARAÍBA_SÃO } \\
\text { JOSÉ DOS CAMPOS }\end{array}$ & 35,18 & 2,14 & 3 & $\begin{array}{l}\text { Ausência de } \\
\text { dados }\end{array}$ & $26 \%$ & $\begin{array}{l}\text { Ausência de } \\
\text { dados }\end{array}$ & $\begin{array}{l}\text { Ausência } \\
\text { de dados }\end{array}$ & 14 & Permanece & 104 \\
\hline 496_UNIVERSIDADE DE FRANCA_FRANCA & 35,15 & 2,14 & 3 & 44 & $26 \%$ & 33 & 18 & 18 & Excluída & Excluída \\
\hline $\begin{array}{l}\text { 1728_FACULDADE INTERAMERICANA DE PORTO } \\
\text { VELHO_PORTO VELHO }\end{array}$ & 35,05 & 2,13 & 3 & 94 & $26 \%$ & 70 & 26 & 41 & Permanece & 105 \\
\hline $\begin{array}{l}\text { 163_UNIVERSIDADE ESTÁCIO DE SÁ_RIO DE } \\
\text { JANEIRO }\end{array}$ & 35,00 & 2,12 & 3 & 43 & $26 \%$ & 32 & 18 & 58 & Permanece & 106 \\
\hline $\begin{array}{l}\text { 449_UNIVERSIDADE LUTERANA DO } \\
\text { BRASIL_SANTA MARIA }\end{array}$ & 34,91 & 2,11 & 3 & 47 & $26 \%$ & 35 & 19 & 12 & Excluída & Excluída \\
\hline $\begin{array}{l}\text { 460_FACULDADE DE ARTES PLÁSTICAS DA } \\
\text { FUNDAÇÃOO ARMANDO ALVARES PENTEADO_SÃO } \\
\text { PAULO }\end{array}$ & 34,69 & 2,08 & 3 & 149 & $26 \%$ & 110 & 30 & 88 & Permanece & 107 \\
\hline 718_UNIVERSIDADE POTIGUAR_NATAL & 34,63 & 2,07 & 3 & 124 & $26 \%$ & 92 & 29 & 88 & Permanece & 108 \\
\hline 143_UNIVERSIDADE DE UBERABA_UBERABA & 34,56 & 2,06 & 3 & 32 & $26 \%$ & 24 & 15 & 38 & Permanece & 109 \\
\hline 277_CENTRO UNIVERSITÁRIO AUGUSTO & 34,38 & 2,04 & 3 & 62 & $26 \%$ & 46 & 22 & 35 & Permanece & 110 \\
\hline
\end{tabular}




\begin{tabular}{|c|c|c|c|c|c|c|c|c|c|c|}
\hline Instituição de ensino & $\begin{array}{l}\text { Nota do } \\
\text { ENADE- } \\
\text { SUSTENTA- } \\
\text { BILIDADE } \\
(0-100)\end{array}$ & \begin{tabular}{|c|} 
Nota final \\
do ENADE- \\
SUSTENTA- \\
BILIDADE \\
$(0-5)$
\end{tabular} & $\begin{array}{l}\text { Conceito } \\
\text { ENADE- } \\
\text { SUSTENTA- } \\
\text { BILIDADE }\end{array}$ & $\begin{array}{l}\text { Número } \\
\text { de } \\
\text { ingressos } \\
\text { no curso } \\
\text { em } 2007\end{array}$ & $\begin{array}{c}\text { Evasão } \\
\text { máxima } \\
\text { considerada }\end{array}$ & $\begin{array}{l}\text { Número } \\
\text { de } \\
\text { ingressos } \\
\text { no início } \\
\text { do curso } \\
\text { subtraindo } \\
\text { a evasão }\end{array}$ & $\begin{array}{c}\text { Amostra } \\
\text { mínima } \\
\text { (a) }\end{array}$ & $\begin{array}{l}\text { Número } \\
\text { de } \\
\text { alunos } \\
\text { que } \\
\text { fizeram } \\
\text { o } \\
\text { ENADE } \\
2011 \\
\text { (b) }\end{array}$ & $\begin{array}{c}\text { Permanece } \\
\text { na } \\
\text { amostra? } \\
\text { (b>=a) }\end{array}$ & $\begin{array}{l}\text { Posição } \\
\text { final }\end{array}$ \\
\hline \multicolumn{11}{|l|}{ MOTTA_RIO DE JANEIRO } \\
\hline 398_UNIVERSIDADE TIRADENTES_ARACAJU & 34,36 & 2,04 & 3 & 95 & $26 \%$ & 70 & 26 & 55 & Permanece & 111 \\
\hline 1557_UNIVERSIDADE FUMEC_BELO HORIZONTE & 34,31 & 2,03 & 3 & 87 & $26 \%$ & 64 & 25 & 61 & Permanece & 112 \\
\hline $\begin{array}{l}\text { 265_FACULDADES INTEGRADAS DE } \\
\text { OURINHOS_OURINHOS }\end{array}$ & 34,27 & 2,03 & 3 & 23 & $26 \%$ & 17 & 12 & 18 & Permanece & 113 \\
\hline $\begin{array}{l}\text { 423_UNIVERSIDADE REGIONAL INTEGRADA DO } \\
\text { ALTO URUGUAI E DAS MISSÕES_SANTIAGO }\end{array}$ & 34,24 & 2,02 & 3 & 25 & $26 \%$ & 19 & 13 & 27 & Permanece & 114 \\
\hline $\begin{array}{l}\text { 466_UNIVERSIDADE ANHEMBI MORUMBI_SÃO } \\
\text { PAULO }\end{array}$ & 34,18 & 2,01 & 3 & 0 & $26 \%$ & 0 & 0 & 108 & Permanece & 115 \\
\hline $\begin{array}{l}\text { 2343_FACULDADE DA AMAZÔNIA } \\
\text { OCIDENTAL_RIO BRANCO }\end{array}$ & 34,07 & 2,00 & 3 & 49 & $26 \%$ & 36 & 20 & 25 & Permanece & 116 \\
\hline $\begin{array}{l}\text { 3_UNIVERSIDADE FEDERAL DE } \\
\text { SERGIPE_LARANJEIRAS }\end{array}$ & 33,91 & 1,98 & 3 & 50 & $12 \%$ & 44 & 21 & 17 & Excluída & Excluída \\
\hline 1772_FACULDADE NORDESTE_FORTALEZA & 33,91 & 1,98 & 3 & 165 & $26 \%$ & 122 & 31 & 31 & Permanece & 117 \\
\hline $\begin{array}{l}\text { 352_CENTRO UNIVERSITÁRIO DE JOÃO } \\
\text { PESSOA_JOÃO PESSOA }\end{array}$ & 33,79 & 1,96 & 3 & 107 & $26 \%$ & 79 & 27 & 61 & Permanece & 118 \\
\hline 1336_FACULDADE ASSIS GURGACZ_CASCAVEL & 33,78 & 1,96 & 3 & 51 & $26 \%$ & 38 & 20 & 42 & Permanece & 119 \\
\hline $\begin{array}{l}\text { 2556_FIAM-FAAM - CENTRO } \\
\text { UNIVERSITÁRIO_SÃO PAULO }\end{array}$ & 33,75 & 1,96 & 3 & 70 & $26 \%$ & 52 & 23 & 50 & Permanece & 120 \\
\hline $\begin{array}{l}142 \text { CENTRO UNIVERSITÁRIO DO } \\
\text { TRIÂNNGULO_UBERLÂNDIA }\end{array}$ & 33,21 & 1,89 & 2 & 62 & $26 \%$ & 46 & 22 & 25 & Permanece & 121 \\
\hline 457_ UNIVERSIDADE BANDEIRANTE DE SÃO & 33,12 & 1,88 & 2 & 77 & $26 \%$ & 57 & 24 & 25 & Permanece & 122 \\
\hline
\end{tabular}


Nota do Nota final ENADE- do ENADESUSTENTA- SUSTENTABILIDADE BILIDADE (0-100)
Conceito Número ENADE-

SUSTENTABILIDADE

\section{de}

ingressos

no curso em 2007
Número

Número

de

Evasão

máxima

considerada

no início

do curso

subtraindo

a evasão de

alunos

Amostra que

mínima fizeram

(a)

o

na

na

amostra?

Posição

final

ENADE

2011

(b)

\section{PAULO_OSASCO}

22_ UNIVERSIDADE PRESBITERIANA

MACKENZIE_SÃO PAULO

610_CENTRO UNIVERSITÁRIO METODISTA

BENNETT_RIO DE JANEIRO

1422_CENTRO UNIVERSITÁRIO DO

NORTE_MANAUS

124_CENTRO UNIVERSITÁRIO DE

ARARAQUARA_ARARAQUARA

162 CENTRO UNIVERSITÁRIO BELAS ARTES DE

SÃO PAULO_SÃO PAULO

1244_FACULDADE BRASILEIRA_VITÓRIA

125_CENTRO UNIVERSITÁRIO DE ARARAS -

ARARAS

338 PONTIFÍCIA UNIVERSIDADE CATÓLICA DE

MINAS GERAIS_BELO HORIZONTE

577_UNIVERSIDADE FEDERAL DE

ALAGOAS_ARAPIRACA

437_UNIVERSIDADE PARANAENSE_CASCAVEL

216 CENTRO UNIVERSITÁRIO METODISTA

IZABELA HENDRIX_BELO HORIZONTE

420_UNIVERSIDADE DE MARÍLIA_MARÍLIA

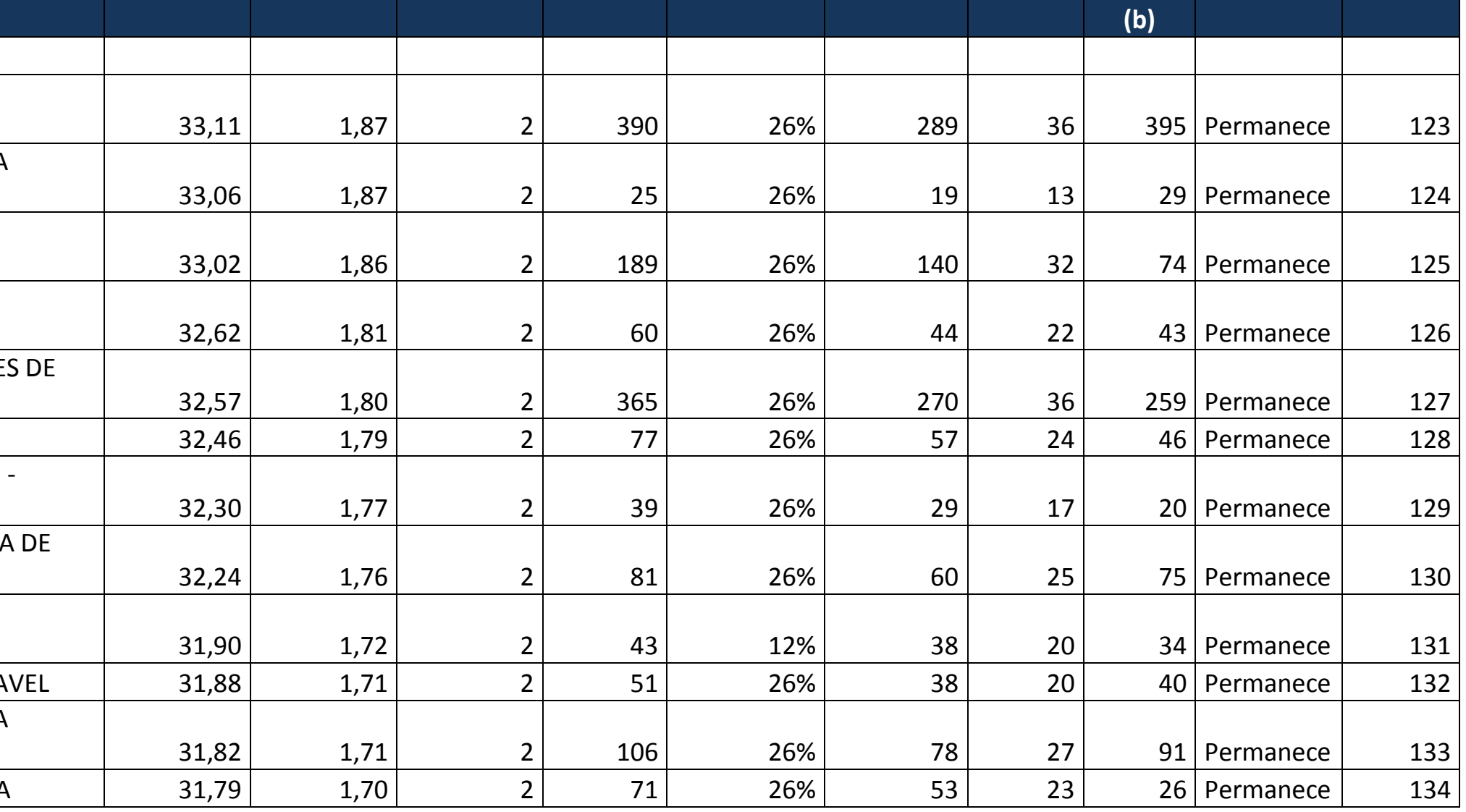


Nota do Nota final

ENADE-

SUSTENTA- SUSTENTA-

BILIDADE BILIDADE

(0-100)

\section{Conceito \\ ENADE- \\ SUSTENTA- \\ BILIDADE}

de

ingress

ingressos

no curso

em 2007

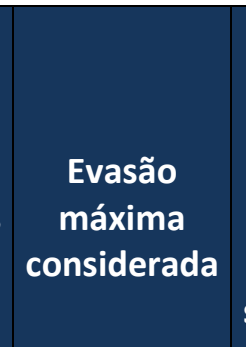

Número

de

ingressos

no início

do curso

subtraindo

a evasão
Número

de

alunos

Amostra que Permanece

mínima fizeram

Posição

(a) amostra? final

ENADE $\quad(b>=a)$

2011

(b)

\begin{tabular}{|c|c|c|c|c|c|c|c|c|c|c|}
\hline $\begin{array}{l}\text { 823_CENTRO UNIVERSITÁRIO DO } \\
\text { MARANHÃO_SÃO LUÍS }\end{array}$ & 31,37 & 1,65 & 2 & 100 & $26 \%$ & 74 & 27 & 59 & Permanece & 135 \\
\hline $\begin{array}{l}\text { 621_CENTRO DE ESTUDOS SUPERIORES DE } \\
\text { MACEIÓ_MACEIÓ }\end{array}$ & 31,22 & 1,63 & 2 & 112 & $26 \%$ & 83 & 28 & 86 & Permanece & 136 \\
\hline 383_UNIVERSIDADE DA AMAZÔNIA_BELÉM & 31,17 & 1,62 & 2 & 93 & $26 \%$ & 69 & 26 & 71 & Permanece & 137 \\
\hline $\begin{array}{l}\text { 410_FACULDADE DE CIÊNCIAS HUMANAS } \\
\text { ESUDA_RECIFE }\end{array}$ & 31,01 & 1,60 & 2 & 102 & $26 \%$ & 75 & 27 & 62 & Permanece & 138 \\
\hline $\begin{array}{l}\text { 266_UNIVERSIDADE METODISTA DE } \\
\text { PIRACICABA_SANTA BÁRBARA D'OESTE }\end{array}$ & 30,99 & 1,60 & 2 & 42 & $26 \%$ & 31 & 18 & 43 & Permanece & 139 \\
\hline 16_ UNIVERSIDADE GAMA FILHO_RIO DE JANEIRO & 30,18 & 1,49 & 2 & 90 & $26 \%$ & 67 & 26 & 61 & Permanece & 140 \\
\hline $\begin{array}{l}\text { 1919_FACULDADE DE CIÊNCIAS EXATAS E } \\
\text { TECNOLÓGICAS SANTO AGOSTINHO - } \\
\text { FACET_MONTES CLAROS }\end{array}$ & 29,81 & 1,44 & 2 & 36 & $26 \%$ & 27 & 16 & 27 & Permanece & 141 \\
\hline $\begin{array}{l}\text { 830_UNIVERSIDADE FEDERAL DO } \\
\text { AMAPÁ_SANTANA }\end{array}$ & 29,36 & 1,38 & 2 & 44 & $12 \%$ & 39 & 20 & 5 & Excluída & Excluída \\
\hline $\begin{array}{l}\text { 1686_FACULDADE BARDDAL DE ARTES } \\
\text { APLICADAS_FLORIANÓPOLIS }\end{array}$ & 29,28 & 1,37 & 2 & 16 & $26 \%$ & 12 & 9 & 8 & Excluída & Excluída \\
\hline $\begin{array}{l}\text { 707_CENTRO UNIVERSITÁRIO CENTRAL } \\
\text { PAULISTA_SÃO CARLOS }\end{array}$ & 28,83 & 1,32 & 2 & 58 & $26 \%$ & 43 & 21 & 25 & Permanece & 142 \\
\hline $\begin{array}{l}\text { 515_CENTRO UNIVERSITÁRIO PLÍNIO } \\
\text { LEITE_NITERÓI }\end{array}$ & 28,81 & 1,31 & 2 & 112 & $26 \%$ & 83 & 28 & 33 & Permanece & 143 \\
\hline 2835_FACULDADE MAURÍCIO DE NASSAU_RECIFE & 28,77 & 1,31 & 2 & 30 & $26 \%$ & 22 & 15 & 48 & Permanece & 144 \\
\hline
\end{tabular}


Nota do Nota final

ENADE-

SUSTENTA- SUSTENTA-

BILIDADE BILIDADE

(0-100)
(0-5)

\section{Conceito Número}

ENADE-

SUSTENTA-

BILIDADE

\section{de}

ingressos

no curso em 2007

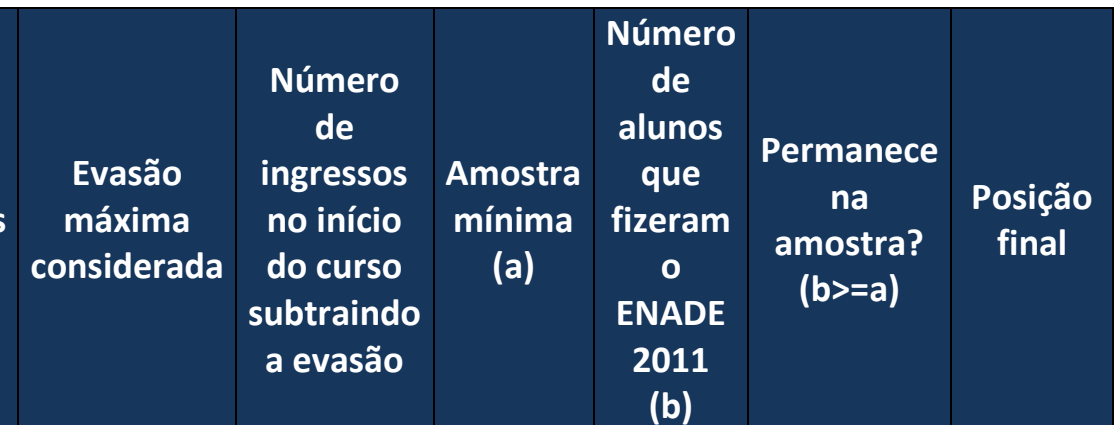

\begin{tabular}{|c|c|c|c|c|c|c|c|c|c|c|}
\hline 316_UNIVERSIDADE NOVE DE JULHO_SÃO PAULO & 28,51 & 1,27 & 2 & 0 & $26 \%$ & 0 & 0 & 143 & Permanece & 145 \\
\hline $\begin{array}{l}\text { 4010_CENTRO UNIVERSITÁRIO } \\
\text { METODISTA_PORTO ALEGRE }\end{array}$ & 28,46 & 1,27 & 2 & 15 & $26 \%$ & 11 & 9 & 7 & Excluída & Excluída \\
\hline $\begin{array}{l}4030 \_ \text {CENTRO UNIVERSITÁRIO } \\
\text { FLUMINENSE_CAMPOS DOS GOYTACAZES }\end{array}$ & 28,39 & 1,26 & 2 & 64 & $26 \%$ & 47 & 22 & 25 & Permanece & 146 \\
\hline $\begin{array}{l}\text { 5439_FACULDADES INTEGRADAS DA UNIÃO } \\
\text { EDUCACIONAL DO PLANALTO CENTRAL - } \\
\text { FACIPLAC_BRASIILIA }\end{array}$ & 27,87 & 1,19 & 2 & $\begin{array}{l}\text { Ausência de } \\
\text { dados }\end{array}$ & $26 \%$ & $\begin{array}{l}\text { Ausência de } \\
\text { dados }\end{array}$ & $\begin{array}{l}\text { Ausência } \\
\text { de dados }\end{array}$ & 5 & Permanece & 147 \\
\hline $\begin{array}{l}\text { 457_UNIVERSIDADE BANDEIRANTE DE SÃO } \\
\text { PAULO_SÃO PAULO }\end{array}$ & 26,61 & 1,02 & 2 & 63 & $26 \%$ & 47 & 22 & 30 & Permanece & 149 \\
\hline $\begin{array}{l}\text { 240_UNIVERSIDADE SANTA ÚRSULA_RIO DE } \\
\text { JANEIRO }\end{array}$ & 26,12 & 0,96 & 2 & 64 & $26 \%$ & 47 & 22 & 38 & Permanece & 150 \\
\hline $\begin{array}{l}\text { 2147_FACULDADE METROPOLITANA DE } \\
\text { MANAUS_MANAUS }\end{array}$ & 22,73 & 0,52 & 1 & 37 & $26 \%$ & 27 & 17 & 14 & Excluída & Excluída \\
\hline $\begin{array}{l}\text { 573_UNIVERSIDADE FEDERAL DO ESPÍRITO } \\
\text { SANTO_VITÓRIA }\end{array}$ & 18,77 & 0,00 & 1 & 71 & $12 \%$ & 62 & 25 & 127 & Permanece & 151 \\
\hline $\begin{array}{l}\text { 572_UNIVERSIDADE FEDERAL } \\
\text { FLUMINENSE_NITERÓI }\end{array}$ & 9,25 & 0,00 & 1 & 60 & $12 \%$ & 53 & 23 & 66 & Permanece & 152 \\
\hline
\end{tabular}




\section{APÊNDICE 02: CLASSIFICAÇÃO DAS DISCIPLINAS POR MÓDULO-TEMA}

Os módulos-tema foram definidos a partir dos conteúdos dos cursos analisados e organizados por áreas disciplinares. Contudo alguns módulos-tema se adequam a mais de uma área.

\section{Disciplinas especializadas:}

Conforto Ambiental (iluminação, térmica, acústica, ventilação, psicrometria)

Sustentabilidade econômica (projeto dos custos)

Sustentabilidade ambiental (Estudos Ambientais, Fundamentos ambientais)

Sustentabilidade social (sociologia)

Tecnologia (Materiais, tecnologia de restauração, técnicas retrospectivas)

Design (objeto, estética, ergonomia, antropometria)

\section{Disciplinas de projeto em ateliê:}

Projeto arquitetônico (reforma, revitalização, reabilitação)

Planejamento urbano (projeto urbanístico)

Projeto paisagístico (paisagismo)

Design (objeto, estética, ergonomia, antropometria, psicometria)

Projeto de graduação

Projetos complementares (hidráulica, elétrica, estrutura, infraestrutura)

\section{Outras disciplinas}

Teoria e História (Introdução à Arquitetura e Urbanismo, Artes, Estudos sociais e econômicos, etc.)

Representação gráfica (Geometria, Comunicação visual, Desenho técnico, Computação Gráfica, Artes, Informática)

Topografia e Geoprocessamento

Cálculo (Estatística, Matemática)

Psicologia ambiental (APO) 
Gerenciamento (Gerenciamento de projetos, de obras, Gestão pública e urbana, Prática profissional, Trabalho social, Construção do edifício, Projeto dos custos)

Metodologia (do trabalho acadêmico)

Tecnologia (Materiais, tecnologia de restauração, técnicas retrospectivas)

Design (objeto, estética, ergonomia, antropometria) 


\section{APÊNDICE 03: SUSTENTABILIDADE NO CURRÍCULO DA UFRN}

\begin{tabular}{|c|c|c|c|c|}
\hline Período & Nome & Conteúdo & $\begin{array}{l}\text { Método de ensino (além das aulas } \\
\text { teóricas) }\end{array}$ & Critérios de avaliação \\
\hline 2 & ESPAÇO E FORMA 02 & $\begin{array}{l}\text { projetar considerando funcionalidade, } \\
\text { condicionantes espaciais e estética }\end{array}$ & $\begin{array}{l}\text { debates/ pesquisa / visitas } \\
\text { /exercícios/ estudo de caso/ } \\
\text { situação-problema }\end{array}$ & $\begin{array}{l}\text { exercícios / trabalho escrito/ } \\
\text { projeto/ representação/ } \\
\text { maquete/ participação }\end{array}$ \\
\hline 2 & $\begin{array}{l}\text { FUNDAMENTOS SOCIAIS } \\
\text { DA ARQUITETURA E } \\
\text { URBANISMO } 01\end{array}$ & $\begin{array}{l}\text { análise da realidade social e ambiental no } \\
\text { contexto brasileiro }\end{array}$ & $\begin{array}{l}\text { leituras/ seminários/ debates/ } \\
\text { pesquisa/ palestra de convidados }\end{array}$ & $\begin{array}{l}\text { exercícios/trabalho escrito/ } \\
\text { apresentação }\end{array}$ \\
\hline 3 & $\begin{array}{l}\text { PLANEJAMENTO E PROJETO } \\
\text { URB. E REGIONAL } 01\end{array}$ & $\begin{array}{l}\text { problemas sociais e ambientais dos processos } \\
\text { de urbanização }\end{array}$ & $\begin{array}{l}\text { leituras/ seminários/ pesquisa/ } \\
\text { exercícios/situaçã- problema }\end{array}$ & $\begin{array}{l}\text { exercícios/ trabalho escrito/ } \\
\text { apresentação/ projeto }\end{array}$ \\
\hline 4 & $\begin{array}{l}\text { PROJETO DE ARQUITETURA } \\
02\end{array}$ & $\begin{array}{l}\text { concepção arquitetônica considerando } \\
\text { criatividade, respeito ao meio ambiente, } \\
\text { coerência e racionalidade construtivas }\end{array}$ & $\begin{array}{l}\text { leituras /apresentação de } \\
\text { seminários/ debates/ visitas/ } \\
\text { exercícios / laboratório/ estudo de } \\
\text { caso/ projeto }\end{array}$ & $\begin{array}{l}\text { exercícios / trabalho escrito/ } \\
\text { apresentação de seminários/ } \\
\text { projeto / representação/ } \\
\text { maquete/ participação } \\
\end{array}$ \\
\hline 4 & $\begin{array}{l}\text { FUNDAMENTOS } \\
\text { AMBIENTAIS }\end{array}$ & $\begin{array}{l}\text { princípios físicos de transmissão de calor, } \\
\text { conforto, bioclimatismo }\end{array}$ & $\begin{array}{l}\text { palestras/ exercícios/ visitas/ } \\
\text { laboratório físico/ laboratório } \\
\text { virtual/ estudos de caso/ projeto }\end{array}$ & $\begin{array}{l}\text { prova / exercícios / trabalho } \\
\text { escrito/ projeto }\end{array}$ \\
\hline
\end{tabular}




\begin{tabular}{|c|c|c|c|c|}
\hline Período & Nome & Conteúdo & $\begin{array}{l}\text { Método de ensino (além das aulas } \\
\text { teóricas) }\end{array}$ & Critérios de avaliação \\
\hline 5 & $\begin{array}{l}\text { PROJETO DE ARQUITETURA } \\
03\end{array}$ & $\begin{array}{l}\text { metodologia projetual, voltada à economia, } \\
\text { racionalização e modulação do projeto. APO }\end{array}$ & $\begin{array}{l}\text { APO/ projeto/ visitas/ pesquisa/ } \\
\text { apresentação }\end{array}$ & 0 \\
\hline 5 & $\begin{array}{l}\text { PLANEJAMENTO DA } \\
\text { PAISAGEM } 01\end{array}$ & $\begin{array}{l}\text { sociologia e psicologia dos jardins, manejo } \\
\text { ecológico, amenização climática }\end{array}$ & 0 & 0 \\
\hline 5 & $\begin{array}{l}\text { PLANEJAMENTO E PROJETO } \\
\text { URBANO E REGIONAL } 03\end{array}$ & $\begin{array}{l}\text { abordagem sobre o processo histórico de } \\
\text { formação das cidades }\end{array}$ & 0 & 0 \\
\hline 5 & CONFORTO AMBIENTAL 01 & carga térmica solar e iluminação natural & $\begin{array}{l}\text { visitas/ exercícios/ laboratórios } \\
\text { físico ou virtual/ estudos de caso/ } \\
\text { situação-problema/ projeto }\end{array}$ & $\begin{array}{l}\text { exercício/ trabalho escrito/ } \\
\text { representação de projeto }\end{array}$ \\
\hline 6 & $\begin{array}{l}\text { PLANEJAMENTO DA } \\
\text { PAISAGEM } 02\end{array}$ & projeto paisagístico em microescala & 0 & 0 \\
\hline 6 & CONFORTO AMBIENTAL 02 & carga térmica solar e iluminação natural & $\begin{array}{l}\text { visitas/ exercícios/ laboratórios } \\
\text { físico ou virtual/ estudos de caso/ } \\
\text { situação-problema/ projeto }\end{array}$ & $\begin{array}{l}\text { exercício/ trabalho escrito/ } \\
\text { representação de projeto }\end{array}$ \\
\hline 7 & $\begin{array}{l}\text { PROJETO DE ARQUITETURA } \\
05\end{array}$ & $\begin{array}{l}\text { atuação em patrimônios históricos, culturais e } \\
\text { ambientais }\end{array}$ & 0 & 0 \\
\hline 7 & $\begin{array}{l}\text { PLANEJAMENTO DA } \\
\text { PAISAGEM } 03\end{array}$ & 0 & 0 & 0 \\
\hline 7 & CONFORTO AMBIENTAL 03 & $\begin{array}{l}\text { acústica em materiais, o processo de } \\
\text { ressonância }\end{array}$ & $\begin{array}{l}\text { apresentação de seminários/ } \\
\text { debates/ pesquisa/ exercícios/ } \\
\text { estudos de caso/ situação- } \\
\text { problema/ projeto }\end{array}$ & $\begin{array}{l}\text { provas/ exercícios/ trabalho } \\
\text { escrito/ apresentação de } \\
\text { seminários/ projeto/ } \\
\text { representação / maquete }\end{array}$ \\
\hline 8 & $\begin{array}{l}\text { PROJETO DE ARQUITETURA } \\
06\end{array}$ & 0 & 0 & 0 \\
\hline
\end{tabular}




\begin{tabular}{|c|l|l|l|l|}
\hline Período & Nome & Conteúdo & $\begin{array}{l}\text { Método de ensino (além das aulas } \\
\text { teóricas) }\end{array}$ & Critérios de avaliação \\
\hline 9 & $\begin{array}{l}\text { TÓPICOS ESPECIAIS EM } \\
\text { PLANEJAMENTO } \\
\text { AMBIENTAL }\end{array}$ & $\begin{array}{l}\text { planejamento, gestão e projeto ambiental no } \\
\text { âmbito do desenvolvimento sustentável }\end{array}$ & $\begin{array}{l}\text { levantamento/ visitas/situação- } \\
\text { problema }\end{array}$ & 0 \\
\hline 9 & $\begin{array}{l}\text { TECNOLOGIAS } \\
\text { ALTERNATIVAS DE } \\
\text { CONFORTO AMBIENTAL }\end{array}$ & 0 & 0 \\
\hline 9 & $\begin{array}{l}\text { ATELIER INTEGRADO DE } \\
\text { ARQUITETURA E }\end{array}$ & $\begin{array}{l}\text { proposta arquitetônica e urbanística de cunho } \\
\text { social, considerando perspectiva } \\
\text { socioambiental, política e legislação e } \\
\text { impactos ambientais. Disciplina com 1 } \\
\text { professor de urbanismo e 1 de construção do } \\
\text { edifício. }\end{array}$ & $\begin{array}{l}\text { leituras/ seminários/ debates/ } \\
\text { pesquisa/palestras/ visitas e } \\
\text { levantamentos/ exercícios /estudo } \\
\text { de caso/ projeto }\end{array}$ & $\begin{array}{l}\text { exercícios/ trabalho escrito/ } \\
\text { apresentação de seminário/ } \\
\text { projeto / representação e } \\
\text { apresentação/ maquete/ } \\
\text { participação }\end{array}$ \\
\hline 10 & $\begin{array}{l}\text { BOTANICA APLICADA AO } \\
\text { MEIO AMBIENTE }\end{array}$ & 0 & 0 \\
\hline
\end{tabular}

*As disciplinas destacadas são de caráter obrigatório no currículo 


\section{APÊNDICE 04: SUSTENTABILIDADE NO CURRÍCULO DA UFRGS}

\begin{tabular}{|c|c|c|c|c|}
\hline Período & Nome & Conteúdo & $\begin{array}{l}\text { Método de ensino (além das aulas } \\
\text { teóricas) }\end{array}$ & Critérios de avaliação \\
\hline 1 & $\begin{array}{l}\text { INTRODUÇÃO AO } \\
\text { PROJETO } \\
\text { ARQUITETÔNICO I }\end{array}$ & $\begin{array}{l}\text { iniciação ao estudo da arquitetura, } \\
\text { conceitos básicos e etapas de projeto, } \\
\text { observação e percepção }\end{array}$ & $\begin{array}{l}\text { seminários/pesquisa/ palestras/ visitas } \\
\text { e levantamento/ exercícios/ projeto/ } \\
\text { PAINEL DE ASSESSORAMENTO (grupo } \\
\text { ou individual) }\end{array}$ & $\begin{array}{l}\text { relatórios/ exercícios/ projetos } \\
\text { desenvolvido/ representação } \\
\text { /maquetes/ participação }\end{array}$ \\
\hline 2 & $\begin{array}{l}\text { INTRODUÇÃO AO } \\
\text { PROJETO } \\
\text { ARQUITETÔNICO II }\end{array}$ & $\begin{array}{l}\text { iniciação ao estudo da arquitetura com } \\
\text { fatores intervenientes, conceitos básicos e } \\
\text { etapas de projeto, observação e percepção }\end{array}$ & $\begin{array}{l}\text { leituras/ seminários/ pesquisa/ } \\
\text { exercícios / visitas /estudos de } \\
\text { caso/situação-problema/ projeto } \\
\text { /seminários dos projetos }\end{array}$ & $\begin{array}{l}\text { exercícios/ projeto desenvolvido/ } \\
\text { representação/ maquete/ } \\
\text { participação/ seminários dos projetos }\end{array}$ \\
\hline 3 & \begin{tabular}{|l|} 
PROJETO \\
ARQUITETÔNICO I
\end{tabular} & estudo relação entre projeto e entorno & $\begin{array}{l}\text { leituras/ palestras/ exercícios/ estudos } \\
\text { de caso/ projeto }\end{array}$ & $\begin{array}{l}\text { projeto / representação e } \\
\text { apresentação/ participação }\end{array}$ \\
\hline 4 & $\begin{array}{l}\text { PROJETO } \\
\text { ARQUITETÔNICO II }\end{array}$ & $\begin{array}{l}\text { estudo de problemas funcionais, formais, } \\
\text { conceituais e metodológicos de } \\
\text { organização e construção do espaço. }\end{array}$ & $\begin{array}{l}\text { pesquisa /exercícios / projeto } \\
\text { individual / PAINEL DE } \\
\text { ASSESSORAMENTO }\end{array}$ & $\begin{array}{l}\text { projeto individual/ representação / } \\
\text { participação }\end{array}$ \\
\hline 5 & $\begin{array}{l}\text { HABITABILIDADE DAS } \\
\text { EDIFICAÇÕES }\end{array}$ & $\begin{array}{l}\text { Física aplicada à habitabilidade. Clima, } \\
\text { ventilação e iluminação }\end{array}$ & $\begin{array}{l}\text { pesquisa/ exercícios/ estudos de caso/ } \\
\text { projeto em grupo/ laboratório físico/ } \\
\text { estudos de caso /PAINEIS DE } \\
\text { ASSESSORAMENTO }\end{array}$ & $\begin{array}{l}\text { provas/ exercícios /projetos em grupo/ } \\
\text { participação }\end{array}$ \\
\hline 5 & \begin{tabular}{|l} 
PROJETO \\
ARQUITETÔNICO III
\end{tabular} & $\begin{array}{l}\text { estudo de problemas funcionais, formais, } \\
\text { conceituais e metodológicos de } \\
\text { organização e construção do espaço com } \\
\text { parâmetros ambientais complexos }\end{array}$ & Projeto & $\begin{array}{l}\text { projeto desenvolvido/ representação/ } \\
\text { maquete/ participação }\end{array}$ \\
\hline
\end{tabular}




\begin{tabular}{|c|c|c|c|c|}
\hline Período & Nome & Conteúdo & $\begin{array}{l}\text { Método de ensino (além das aulas } \\
\text { teóricas) }\end{array}$ & Critérios de avaliação \\
\hline 6 & $\begin{array}{l}\text { LUMINOTÉCNICA } \\
\text { APLICADA À } \\
\text { ARQUITETURA }\end{array}$ & $\begin{array}{l}\text { projeto luminotécnico de espaços internos } \\
\text { baseado em aspectos } \\
\text { visuais/compositivos, biológicos e } \\
\text { emocionais }\end{array}$ & $\begin{array}{l}\text { pesquisa/ debates/ visitas e } \\
\text { levantamento/ palestras / exercícios / } \\
\text { laboratório físico/ projeto em grupo e } \\
\text { individuais /PAINÉIS DE } \\
\text { ASSESSORAMENTO }\end{array}$ & $\begin{array}{l}\text { trabalho escrito/ exercícios/ } \\
\text { laboratório físico e virtual /projeto/ } \\
\text { representação e apresentação/ } \\
\text { participação/ painéis de } \\
\text { assessoramento/ prova }\end{array}$ \\
\hline 6 & $\begin{array}{l}\text { PROJETO } \\
\text { ARQUITETÔNICO IV }\end{array}$ & $\begin{array}{l}\text { estudo de problemas funcionais, formais, } \\
\text { conceituais e metodológicos de } \\
\text { organização e construção da arquitetura } \\
\text { de interiores e espaços menores } \\
\text { ao oficio da arquitetura dos interiores e de } \\
\text { edificações de áreas menores }\end{array}$ & $\begin{array}{l}\text { palestra/ projetos / seminário dos } \\
\text { projetos }\end{array}$ & $\begin{array}{l}\text { projeto / participação/ seminário dos } \\
\text { projetos }\end{array}$ \\
\hline 6 & URBANISMO I & Arquitetura paisagística e espaço urbano & leituras/ projeto & projeto / representação/ participação \\
\hline 7 & ACÚSTICA APLICADA & $\begin{array}{l}\text { Habilitar para a execução de projetos } \\
\text { acústicos, levando em conta o } \\
\text { condicionamento e o isolamento acústico. }\end{array}$ & $\begin{array}{l}\text { leituras/ pesquisa/laboratório físico/ } \\
\text { estudos de caso/ exercícios/ situação - } \\
\text { problema/ projeto/ debates }\end{array}$ & provas /exercícios / trabalho/ projeto \\
\hline 7 & $\begin{array}{l}\text { MORFOLOGIA E } \\
\text { INFRAESTRUTURA } \\
\text { URBANA }\end{array}$ & $\begin{array}{l}\text { morfologia e infraestrutura urbana: } \\
\text { projeto, planejamento, análise e avaliação } \\
\text { de desempenho }\end{array}$ & Exercícios & provas/ exercícios em grupo \\
\hline 7 & $\begin{array}{l}\text { PROJETO } \\
\text { ARQUITETÔNICO V }\end{array}$ & projetos de revitalização de áreas urbanas & $\begin{array}{l}\text { pesquisas/visitas/exercícios/ projeto } \\
\text { em grupo/ palestras /PAINÉIS DE } \\
\text { ASSESSORAMENTO }\end{array}$ & $\begin{array}{l}\text { projeto/ representação e } \\
\text { apresentação/ maquete/ participação }\end{array}$ \\
\hline 7 & URBANISMO II & $\begin{array}{l}\text { Conceitos básicos. Características e inter- } \\
\text { relações de planejamento e } \\
\text { desenvolvimento do espaço urbano }\end{array}$ & $\begin{array}{l}\text { pesquisa/ visitas /exercícios em grupo/ } \\
\text { projeto/ PAINÉIS DE } \\
\text { ASSESSORAMENTO }\end{array}$ & $\begin{array}{l}\text { prova / relatório /projeto/ } \\
\text { representação e apresentação / } \\
\text { maquete/ participação }\end{array}$ \\
\hline
\end{tabular}




\begin{tabular}{|c|c|c|c|c|}
\hline Período & Nome & Conteúdo & $\begin{array}{l}\text { Método de ensino (além das aulas } \\
\text { teóricas) }\end{array}$ & Critérios de avaliação \\
\hline 8 & $\begin{array}{l}\text { PROJETO } \\
\text { ARQUITETÔNICO VI }\end{array}$ & $\begin{array}{l}\text { projetos de grande escala e diversidade } \\
\text { funcional }\end{array}$ & $\begin{array}{l}\text { pesquisa/seminários/ palestras/ } \\
\text { visitas/ exercícios/ projeto /PAINÉIS DE } \\
\text { ASSESSORAMENTO }\end{array}$ & $\begin{array}{l}\text { apresentação de seminários/ projeto / } \\
\text { representação e apresentação/ } \\
\text { maquete/ participação }\end{array}$ \\
\hline 8 & URBANISMO III & $\begin{array}{l}\text { Relações entre planejamento urbano e } \\
\text { desenho urbano. Aplicações de } \\
\text { dispositivos de desenho e gestão urbana }\end{array}$ & $\begin{array}{l}\text { leituras/ seminários/ debates/ } \\
\text { pesquisa/ palestras de convidados/ } \\
\text { exercícios/ visitas de campo/estudos } \\
\text { de caso/ situação-problema/ projeto/ } \\
\text { seminarios dos projetos }\end{array}$ & $\begin{array}{l}\text { exercícios/trabalho } \\
\text { escrito/apresentação de seminários/ } \\
\text { projeto/ representação e } \\
\text { apresentação/ maquete/ participação/ } \\
\text { seminário dos projetos }\end{array}$ \\
\hline 9 & $\begin{array}{l}\text { CLIMATIZAÇÃO } \\
\text { ARTIFICIAL - } \\
\text { ARQUITETURA }\end{array}$ & $\begin{array}{l}\text { Fundamentos de transmissão de calor, } \\
\text { psicrometria, conforto térmico e balanços } \\
\text { energéticos. Cálculo de cargas térmicas. }\end{array}$ & $\begin{array}{l}\text { debates/ exercícios/visitas / estudos } \\
\text { de caso/ situação-problema/ projeto }\end{array}$ & $\begin{array}{l}\text { projeto desenvolvido/ representação/ } \\
\text { participação }\end{array}$ \\
\hline 9 & $\begin{array}{l}\text { PROJETO } \\
\text { ARQUITETÔNICO VII }\end{array}$ & arquitetura e desenho urbano & $\begin{array}{l}\text { palestras/ exercícios/visitas/ estudos } \\
\text { de caso/ situação-problema/ projeto }\end{array}$ & $\begin{array}{l}\text { exercícios/trabalho escrito/ projeto/ } \\
\text { representação/ maquete/ participação }\end{array}$ \\
\hline \multirow[t]{2}{*}{9} & URBANISMO IV & $\begin{array}{l}\text { Detalhamento de propostas gerais e } \\
\text { medidas físicas quanto à intervenção em } \\
\text { determinado espaço intra-urbano. }\end{array}$ & $\begin{array}{l}\text { pesquisa / leitura/ debate/ visitas/ } \\
\text { projeto/ PAINÉIS DE } \\
\text { ASSESSORAMENTO }\end{array}$ & $\begin{array}{l}\text { projeto em grupo e individual/ } \\
\text { representação e apresentação / } \\
\text { trabalho escrito /apresentação de } \\
\text { seminários/ participação }\end{array}$ \\
\hline & \begin{tabular}{|l} 
ESTUDO DA \\
VEGETAÇÃOO
\end{tabular} & $\begin{array}{l}\text { Fornecer base botânica e ecológica para } \\
\text { estudos paisagísticos. Reconhecer a } \\
\text { importância da vegetação natural e da } \\
\text { flora nativa no planejamento urbano. }\end{array}$ & seminários/ visitas/ estudos de caso & $\begin{array}{l}\text { trabalho escrito/ apresentação/ } \\
\text { participação }\end{array}$ \\
\hline
\end{tabular}




\begin{tabular}{|c|c|c|c|c|}
\hline Período & Nome & Conteúdo & $\begin{array}{l}\text { Método de ensino (além das aulas } \\
\text { teóricas) }\end{array}$ & Critérios de avaliação \\
\hline & HABITABILIDADE B & $\begin{array}{l}\text { Estudo da problemática da habitabilidade } \\
\text { dos espaços externos e dos conjuntos } \\
\text { arquitetônicos, sob o ponto de vista da } \\
\text { ventilação, da iluminação, da acústica e do } \\
\text { conforto térmico. }\end{array}$ & $\begin{array}{l}\text { projeto individual / estudos de caso/ } \\
\text { projeto / PAINÉIS DE } \\
\text { ASSESSORAMENTO }\end{array}$ & $\begin{array}{l}\text { projeto / representação e } \\
\text { apresentação/ participação }\end{array}$ \\
\hline & $\begin{array}{l}\text { INTRODUÇÃO } \\
\text { ECOLOGIA }\end{array}$ & $\begin{array}{l}\text { A estrutura da Ecologia em suas } \\
\text { subdivisões para uma visão mais ampla } \\
\text { dos fenômenos ecológicos, considerando } \\
\text { organismos, populações, comunidades, } \\
\text { ecossistemas e a biosfera. }\end{array}$ & $\begin{array}{l}\text { leituras/ seminários/ debates/ } \\
\text { pesquisa/ palestras/ exercícios/visitas } \\
\text { de campo/ }\end{array}$ & $\begin{array}{l}\text { prova / exercícios/trabalho escrito/ } \\
\text { apresentação }\end{array}$ \\
\hline & $\begin{array}{l}\text { PAISAGISMO E MEIO } \\
\text { AMBIENTE }\end{array}$ & $\begin{array}{l}\text { projetar e organizar o espaço aberto em } \\
\text { pequena a grande escala, na paisagem } \\
\text { rural, urbana e natural. Valorizando e } \\
\text { combinando as qualidades da natureza } \\
\text { com as necessidades dos seres humanos. }\end{array}$ & $\begin{array}{l}\text { projeto / PAINÉIS DE } \\
\text { ASSESSORAMENTO }\end{array}$ & $\begin{array}{l}\text { projeto/ representação e } \\
\text { apresentação/ prova }\end{array}$ \\
\hline & \begin{tabular}{|l} 
PERCEPÇÃO \\
AMBIENTAL E \\
URBANISMO \\
\end{tabular} & & & \\
\hline & $\begin{array}{l}\text { TÓPICOS ESPECIAIS } \\
\text { EM URBANISMO II-A }\end{array}$ & $\begin{array}{l}\text { conceitos básicos de luminotécnica e de } \\
\text { projeto de iluminação artificial de espaços } \\
\text { internos a partir de um modelo conceitual } \\
\text { que envolva aspectos visuais, biológicos e } \\
\text { emocionais }\end{array}$ & $\begin{array}{l}\text { palestras/ debates/ levantamentos / } \\
\text { laboratório físico e virtual / projeto em } \\
\text { grupo/ PAINÉIS DE ASSESSORAMENTO }\end{array}$ & $\begin{array}{l}\text { relatórios /projeto/ representação e } \\
\text { apresentação/ participação } \\
\text { /prova/PAINÉIS DE ASSESSORAMENTO }\end{array}$ \\
\hline
\end{tabular}

*As disciplinas destacadas são de caráter obrigatório no currículo 


\section{APÊNDICE 05: SUSTENTABILIDADE NO CURRÍCULO DA USP}

\begin{tabular}{|c|c|c|c|c|}
\hline Período & Nome & Conteúdo & $\begin{array}{l}\text { Método de ensino (além das aulas } \\
\text { teóricas) }\end{array}$ & Critérios de avaliação \\
\hline 1 & $\begin{array}{l}\text { Conforto Ambiental } 1 \text { - } \\
\text { Fundamentos }\end{array}$ & $\begin{array}{l}\text { introduz conforto e eficiência } \\
\text { energética }\end{array}$ & $\begin{array}{l}\text { leituras/seminário/ palestra/ visita/ } \\
\text { laboratório físico/ estudo de caso/ } \\
\text { seminários }\end{array}$ & prova/ trabalho escrito/ apresentação \\
\hline 2 & Arquitetura - Projeto I & Projeto de Arquitetura & $\begin{array}{l}\text { seminários/ pesquisa/ visitas/ situação- } \\
\text { problema/ projeto }\end{array}$ & $\begin{array}{l}\text { projeto desenvolvido/ representação e } \\
\text { apresentação/ maquete/ participação/ } \\
\text { seminários }\end{array}$ \\
\hline 2 & Construção do Edifício 2 & Construção do edifício & $\begin{array}{l}\text { palestras/ visitas/ situação-problema/ } \\
\text { canteiro experimental }\end{array}$ & $\begin{array}{l}\text { trabalho escrito/ prática no canteiro } \\
\text { experimental }\end{array}$ \\
\hline 2 & $\begin{array}{l}\text { Conforto Ambiental } 2 \text { - } \\
\text { Ergonomia }\end{array}$ & $\begin{array}{l}\text { ergonomia e psicrometria nos } \\
\text { ambientes construídos }\end{array}$ & $\begin{array}{l}\text { seminários/ palestra/ exercícios/visitas/ } \\
\text { laboratório físico/ estudos de caso }\end{array}$ & $\begin{array}{l}\text { exercícios/trabalho escrito/ } \\
\text { apresentação }\end{array}$ \\
\hline
\end{tabular}




\begin{tabular}{|c|c|c|c|c|}
\hline Período & Nome & Conteúdo & $\begin{array}{l}\text { Método de ensino (além das aulas } \\
\text { teóricas) }\end{array}$ & Critérios de avaliação \\
\hline 4 & Planejamento Urbano II & $\begin{array}{l}\text { introduzir o planejamento na } \\
\text { escala intraurbana, regional, } \\
\text { urbana e local. }\end{array}$ & $\begin{array}{l}\text { leituras/ seminários/ debates/ pesquisa/ } \\
\text { palestras/ exercícios/ visitas de campo/ } \\
\text { laboratório físico/ estudos de caso/ } \\
\text { projeto/ seminário dos projetos }\end{array}$ & $\begin{array}{l}\text { exercícios/trabalho escrito/ } \\
\text { apresentação/ projeto desenvolvido/ } \\
\text { representação/ maquete/ } \\
\text { participação/ seminários dos projetos }\end{array}$ \\
\hline 5 & $\begin{array}{l}\text { Técnicas Retrospectivas. } \\
\text { Estudo e Preservação dos } \\
\text { Bens Culturais. }\end{array}$ & $\begin{array}{l}\text { Técnicas Retrospectivas. Estudo } \\
\text { e Preservação dos Bens } \\
\text { Culturais. }\end{array}$ & $\begin{array}{l}\text { leituras/seminários/ debates/palestras/ } \\
\text { visitas }\end{array}$ & prova/ trabalho escrito \\
\hline 5 & $\begin{array}{l}\text { Planejamento de Estruturas } \\
\text { Urbanas e Regionais - A } \\
\text { Formação do Espaço } \\
\text { Nacional }\end{array}$ & $\begin{array}{l}\text { introduzir elementos do } \\
\text { planejamento no espaço } \\
\text { nacional considerando as } \\
\text { características peculiares da } \\
\text { sociedade brasileira }\end{array}$ & $\begin{array}{l}\text { leituras/ situação-problema/projeto/ } \\
\text { seminário dos projetos }\end{array}$ & $\begin{array}{l}\text { trabalho escrito/ apresentação de } \\
\text { seminário/ projeto desenvolvido }\end{array}$ \\
\hline 6 & $\begin{array}{l}\text { Infra-estrutura Urbana e } \\
\text { Meio Ambiente }\end{array}$ & $\begin{array}{l}\text { infraestrutura no ambiente } \\
\text { urbano e seus impactos }\end{array}$ & $\begin{array}{l}\text { palestras/ exercícios / visitas/ situação- } \\
\text { problema }\end{array}$ & prova/ exercícios/trabalho escrito \\
\hline 6 & $\begin{array}{l}\text { Conforto Ambiental } 4 \text { - } \\
\text { Térmica }\end{array}$ & conforto térmico & $\begin{array}{l}\text { exercícios/ exercícios de campo / } \\
\text { laboratório físico e virtual / prática de } \\
\text { projeto em ateliê- grupo }\end{array}$ & exercícios / provas / trabalho em grupo \\
\hline 6 & $\begin{array}{l}\text { Conforto Ambiental } 5 \text { - } \\
\text { Acústica }\end{array}$ & conforto acústico & $\begin{array}{l}\text { exercícios, pesquisa de campo, / } \\
\text { seminário / prática de projeto }\end{array}$ & exercícios / seminários / trabalho \\
\hline 7 & $\begin{array}{l}\text { Conforto Ambiental 6- } \\
\text { Integradas }\end{array}$ & $\begin{array}{l}\text { integração em projeto de } \\
\text { ergonomia, iluminação, térmica } \\
\text { e acústica }\end{array}$ & $\begin{array}{l}\text { exercícios, exercícios de campo, / } \\
\text { seminário / prática de projeto }\end{array}$ & $\begin{array}{l}\text { projeto em grupo, participação, } \\
\text { apresentação (texto e desenhos) }\end{array}$ \\
\hline
\end{tabular}




\begin{tabular}{|c|c|c|c|c|}
\hline Período & Nome & Conteúdo & $\begin{array}{l}\text { Método de ensino (além das aulas } \\
\text { teóricas) }\end{array}$ & Critérios de avaliação \\
\hline 7 & Projeto dos Custos & $\begin{array}{l}\text { custos diretos e indiretos de } \\
\text { uma construção e seus } \\
\text { impactos }\end{array}$ & $\begin{array}{l}\text { seminários / debates/ exercícios/ } \\
\text { laboratório virtual/ situação-problema/ } \\
\text { projeto/ seminários }\end{array}$ & $\begin{array}{l}\text { exercícios/ projeto desenvolvido/ } \\
\text { seminários dos projetos }\end{array}$ \\
\hline 8 & $\begin{array}{l}\text { Reciclagem e Reforma de } \\
\text { Edificação }\end{array}$ & $\begin{array}{l}\text { projeto de reciclagem ou } \\
\text { reforma de edificações }\end{array}$ & $\begin{array}{l}\text { seminários/ debates/ pesquisa/ visitas/ } \\
\text { projeto }\end{array}$ & $\begin{array}{l}\text { projeto/ participação/ seminários dos } \\
\text { projetos }\end{array}$ \\
\hline 8 & $\begin{array}{l}\text { Ambiente Construído e } \\
\text { Desenvolvimento } \\
\text { Sustentável }\end{array}$ & $\begin{array}{l}\text { planejamento urbano com } \\
\text { sustentabilidade (econômica, } \\
\text { social e ambiental) }\end{array}$ & $\begin{array}{l}\text { Visitas/seminários/laboratório } \\
\text { virtual/projeto }\end{array}$ & exercícios/ projetos urbanos \\
\hline 8 & Renovação Urbana & $\begin{array}{l}\text { deterioração urbana e } \\
\text { necessidade de renovação }\end{array}$ & $\begin{array}{l}\text { seminários/ debates / estudos de caso/ } \\
\text { projeto }\end{array}$ & seminários/projetos \\
\hline 8 & $\begin{array}{l}\text { O Projeto da lluminação no } \\
\text { Exercício da Arquitetura }\end{array}$ & $\begin{array}{l}\text { Aprofundamento na praxis do } \\
\text { projeto de iluminação }\end{array}$ & visitas/ exercícios/ debates / projeto & $\begin{array}{l}\text { projeto individual ou em grupo }(60 \%) / \\
\text { trabalho escrito }(30 \%)\end{array}$ \\
\hline 8 & $\begin{array}{l}\text { Arquitetura, Ambiente e } \\
\text { Desenvolvimento } \\
\text { Sustentável }\end{array}$ & $\begin{array}{l}\text { Desenvolvimento sustentável } \\
\text { na arquitetura e no urbanismo }\end{array}$ & $\begin{array}{l}\text { seminário/ pesquisa/ projeto / } \\
\text { apresentação do projeto }\end{array}$ & $\begin{array}{l}\text { projeto }(60 \%) / \text { seminários e pesquisa } \\
(40 \%)\end{array}$ \\
\hline 8 & $\begin{array}{l}\text { Adequação dos Projetos de } \\
\text { Edificações a Leis e Normas } \\
\text { Sobre Acústica }\end{array}$ & $\begin{array}{l}\text { Desenvolvimento de projetos } \\
\text { de acústica }\end{array}$ & projeto (em grupo) & trabalho em grupo \\
\hline
\end{tabular}




\begin{tabular}{|r|l|l|l|l|}
\hline Período & Nome & Conteúdo & $\begin{array}{l}\text { Método de ensino (além das aulas } \\
\text { teóricas) }\end{array}$ & Critérios de avaliação \\
\hline 9 & $\begin{array}{l}\text { Prática Profissional e } \\
\text { Organização do Trabalho }\end{array}$ & $\begin{array}{l}\text { Prática Profissional e } \\
\text { Organização do Trabalho }\end{array}$ & $\begin{array}{l}\text { palestras/laboratório físico/ laboratório } \\
\text { virtual/ seminários }\end{array}$ & Prova \\
\hline 9 & $\begin{array}{l}\text { Design para a } \\
\text { Sustentabilidade }\end{array}$ & $\begin{array}{l}\text { design de produtos } \\
\text { ambientalmente sustentável }\end{array}$ & visitas/ seminários /pratica projetual & projeto \\
\hline 9 & $\begin{array}{l}\text { Análise Paisagístico- } \\
\text { ambiental }\end{array}$ & $\begin{array}{l}\text { condicionantes paisagísticas e } \\
\text { ambientais nos projetos }\end{array}$ & exercícios / seminários/visitas & exercícios / projeto \\
\hline
\end{tabular}

*As disciplinas destacadas são de caráter obrigatório no currículo 


\section{APÊNDICE 06: SUSTENTABILIDADE NO CURRÍCULO DA UNB}

\begin{tabular}{|c|c|c|c|c|}
\hline Período & Nome & Conteúdo & $\begin{array}{l}\text { Método de ensino (além das aulas } \\
\text { teóricas) }\end{array}$ & Critérios de avaliação \\
\hline 1 & $\begin{array}{l}\text { PROJETO } \\
\text { ARQUITETONICO } 1\end{array}$ & $\begin{array}{l}\text { Resposta a situações simples, com } \\
\text { compromisso com o urbano, considerados os } \\
\text { aspectos ambientais, tecnológicos, funcionais e } \\
\text { estéticos e sua volumetria }\end{array}$ & $\begin{array}{l}\text { leituras/ debates / pesquisa / } \\
\text { exercícios individuais ou em } \\
\text { grupo/ visitas/ situação- } \\
\text { problema/ laboratório físico/ } \\
\text { projeto }\end{array}$ & $\begin{array}{l}\text { exercícios/ seminários/ projeto / } \\
\text { representação / maquete/ } \\
\text { participação/ painel de } \\
\text { assessoramento }\end{array}$ \\
\hline 2 & $\begin{array}{l}\text { PROJETO ARQ LINGUA } \\
\text { E EXPRESSÃO }\end{array}$ & $\begin{array}{l}\text { projeto de edificaçães de pequeno porte com } \\
\text { forte conteúdo simbólico de caráter coletivo. } \\
\text { Ênfase no exercício de simbolização e } \\
\text { expressão estética, além da resolução dos } \\
\text { aspectos funcionais, ambientais e construtivos }\end{array}$ & & \\
\hline 2 & $\begin{array}{l}\text { EST AMBIENTAIS- } \\
\text { BIOCLIMATISMO }\end{array}$ & $\begin{array}{l}\text { Levantamento, análise e sistematização dos } \\
\text { fatores ambientais : geologia, relevo, solos, } \\
\text { hidrografia, vegetação, clima e dos processos } \\
\text { naturais de modificação da paisagem. }\end{array}$ & $\begin{array}{l}\text { leituras/ seminários/ debates/ } \\
\text { pesquisa/visitas }\end{array}$ & $\begin{array}{l}\text { exercícios/trabalho escrito/ } \\
\text { projeto/ maquete/ }\end{array}$ \\
\hline 3 & $\begin{array}{l}\text { PROJ ARQUITETURA - } \\
\text { HABITAÇÃOO }\end{array}$ & $\begin{array}{l}\text { Prática em projetos de edificações residenciais } \\
\text { uni e/ou plurifamiliares, precedida de aulas } \\
\text { teóricas e de debates sobre a questão } \\
\text { habitacional. }\end{array}$ & $\begin{array}{l}\text { pesquisa /visitas/ estudos de caso/ } \\
\text { projeto }\end{array}$ & $\begin{array}{l}\text { exercícios/ seminário / projeto } \\
\text { /representação do projeto/ } \\
\text { maquetes/seminário dos } \\
\text { projetos }\end{array}$ \\
\hline 3 & $\begin{array}{l}\text { CONFORTO TERMICO } \\
\text { AMBIENTAL }\end{array}$ & $\begin{array}{l}\text { Física aplicada à Arquitetura e Urbanismo. } \\
\text { Bbioclimatologia humana: clima e exigências } \\
\text { humanas quanto ao conforto térmico }\end{array}$ & $\begin{array}{l}\text { pesquisa/ visitas de campo/ } \\
\text { laboratorio fisico/ situação- } \\
\text { problema/ projeto }\end{array}$ & $\begin{array}{l}\text { exercícios/ trabalho escrito/ } \\
\text { projeto }\end{array}$ \\
\hline
\end{tabular}




\begin{tabular}{|c|c|c|c|c|}
\hline Período & Nome & Conteúdo & $\begin{array}{l}\text { Método de ensino (além das aulas } \\
\text { teóricas) }\end{array}$ & Critérios de avaliação \\
\hline 4 & $\begin{array}{l}\text { PROJ DE ARQ DE } \\
\text { GRANDES VAOS }\end{array}$ & $\begin{array}{l}\text { Projeto de edificações cujo programa exija } \\
\text { grandes vãos, com problemas específicos de } \\
\text { segurança e de controle ambiental }\end{array}$ & $\begin{array}{l}\text { leituras/seminários/ debates/ } \\
\text { pesquisa/ palestras/ exercícios/ } \\
\text { visitas/ laboratório físico/ } \\
\text { laboratório virtual/ estudos de } \\
\text { caso/ projeto/seminários dos } \\
\text { projetos }\end{array}$ & $\begin{array}{l}\text { exercícios/seminários/ projeto/ } \\
\text { representação/ maquete/ } \\
\text { participação/ painel de } \\
\text { assessoramento }\end{array}$ \\
\hline 4 & CONFORTO SONORO & Conforto acústico (sonoro) & $\begin{array}{l}\text { leituras/ seminários/ debates/ } \\
\text { pesquisa/ exercícios/visitas/ } \\
\text { estudos de caso/ situação- } \\
\text { problema/ projeto }\end{array}$ & $\begin{array}{l}\text { exercícios/trabalho escrito/ } \\
\text { projeto/ representaçao/ } \\
\text { participação }\end{array}$ \\
\hline 4 & $\begin{array}{l}\text { CONFORTO } \\
\text { AMBIENTAL } \\
\text { LUMINOSO }\end{array}$ & $\begin{array}{l}\text { Estudo do controle da luz no urbanismo e na } \\
\text { arquitetura, com ênfase no estudo da luz } \\
\text { natural. }\end{array}$ & & \\
\hline 5 & $\begin{array}{l}\text { PROJ ARQUIT DE EDIF } \\
\text { EM ALTURA }\end{array}$ & $\begin{array}{l}\text { Projetos de edificações em alltura, a nível de } \\
\text { equipamentos urbanos, e proposta de } \\
\text { ocupação física, considerando desde as suas } \\
\text { necessidades ambientais e possibilidades } \\
\text { econômicas, até seu significado cultural. }\end{array}$ & $\begin{array}{l}\text { seminários/ pesquisa/visitas de } \\
\text { campo/ estudos de caso/ projeto/ } \\
\text { seminários dos projetos }\end{array}$ & $\begin{array}{l}\text { trabalho escrito/ apresentação/ } \\
\text { projeto desenvolvido/ } \\
\text { representação/ maquete/ } \\
\text { seminário dos projetos }\end{array}$ \\
\hline 6 & $\begin{array}{l}\text { PROJ DE ARQ DE FUNC } \\
\text { COMPLEXAS }\end{array}$ & $\begin{array}{l}\text { Projeto de edificação com grande número de } \\
\text { espaços específicos para funções interagentes. }\end{array}$ & $\begin{array}{l}\text { palestras / seminários/ projeto/ } \\
\text { seminário dos projetos }\end{array}$ & $\begin{array}{l}\text { exercícios/ seminário / projeto } \\
\text { /representação do projeto/ } \\
\text { maquetes/seminário dos } \\
\text { projetos }\end{array}$ \\
\hline 6 & \begin{tabular}{|l} 
PROJETO \\
PAISAGÍSTICO 1
\end{tabular} & $\begin{array}{l}\text { Intervenção na paisagem urbana. Projetos de } \\
\text { espaços urbanos livres e de espaços abertos } \\
\text { vinculados à edificação. }\end{array}$ & $\begin{array}{l}\text { leituras/ pesquisa/ exercícios / } \\
\text { visitas/ estudos de caso/ projeto }\end{array}$ & $\begin{array}{l}\text { prova/ exercícios/trabalho/ } \\
\text { projeto desenvolvido/ maquete/ } \\
\text { participação }\end{array}$ \\
\hline
\end{tabular}




\begin{tabular}{|c|c|c|c|c|}
\hline Período & Nome & Conteúdo & $\begin{array}{l}\text { Método de ensino (além das aulas } \\
\text { teóricas) }\end{array}$ & Critérios de avaliação \\
\hline 7 & $\begin{array}{l}\text { PROJETO DE } \\
\text { URBANISMO } 1\end{array}$ & $\begin{array}{l}\text { Aplicação de técnicas e procedimentos } \\
\text { urbanísticos com ênfase no dimensionamento } \\
\text { de um programa de necessidades, } \\
\text { considerando os aspectos funcionais, } \\
\text { ambientais e comportamentais. }\end{array}$ & $\begin{array}{l}\text { projeto/ exercícios/visitas de } \\
\text { campo }\end{array}$ & projeto desenvolvido /maquete \\
\hline 7 & $\begin{array}{l}\text { PLANEJAMENTO } \\
\text { URBANO }\end{array}$ & $\begin{array}{l}\text { Introdução à teoria, à prática e à evolução } \\
\text { histórica do planejamento urbano e regional. }\end{array}$ & $\begin{array}{l}\text { leituras/ seminários/ debates/ } \\
\text { pesquisa/ exercícios/ visitas/ } \\
\text { estudos de caso/ projeto }\end{array}$ & $\begin{array}{l}\text { prova/ exercícios/trabalho } \\
\text { escrito/ seminário/ projeto/ } \\
\text { representação/ maquete/ } \\
\text { participação/ painel de } \\
\text { assessoramento }\end{array}$ \\
\hline 8 & $\begin{array}{l}\text { PROJETO DE } \\
\text { URBANISMO } 2\end{array}$ & $\begin{array}{l}\text { Aplicação de técnicas e procedimentos } \\
\text { urbanísticos com ênfase nos aspectos de infra- } \\
\text { estrutura urbana, legislação, custos, } \\
\text { financiamento e gestão }\end{array}$ & $\begin{array}{l}\text { seminários/ debates/ palestras/ } \\
\text { visitas/ projeto/ seminário dos } \\
\text { projetos }\end{array}$ & $\begin{array}{l}\text { trabalho escrito/ projeto/ } \\
\text { representação/ participação/ } \\
\text { painel de assessoramento }\end{array}$ \\
\hline 8 & $\begin{array}{l}\text { PROJ ARQ/URB- TÉCN } \\
\text { RETROSP }\end{array}$ & $\begin{array}{l}\text { Teoria, práticas projetuais e soluções } \\
\text { tecnológicas para a preservação, conservação, } \\
\text { restauração, recontrução, reabilitação e } \\
\text { reutilização de edificações, conjuntos } \\
\text { arquitetônicos e cidades. }\end{array}$ & estudos de caso & \\
\hline Optativa & $\begin{array}{l}155438 \text { - ATELIE PRO } \\
\text { ARQ URB } \\
\text { SUSTENTÁVEL }\end{array}$ & $\begin{array}{l}\text { Aplicação de métodos e técnicas que } \\
\text { contemplem, orientem e estimulem a } \\
\text { participação social do usuário e a geração de } \\
\text { padrões de intervenção que reforcem a } \\
\text { dimensão social da arquitetura e do urbanismo. }\end{array}$ & & \\
\hline
\end{tabular}




\begin{tabular}{|l|l|l|l|l|}
\hline Período & Nome & Conteúdo & $\begin{array}{l}\text { Método de ensino (além das aulas } \\
\text { teóricas) }\end{array}$ & Critérios de avaliação \\
\hline Optativa & $\begin{array}{l}154679 \text { - CONF } \\
\text { AMBIENTAL LUMIN E } \\
\text { ACUSTI }\end{array}$ & $\begin{array}{l}\text { Fisica aplicada à Arquitetura e Urbanismo: } \\
\text { Iluminação natural, Acústica e Controle do } \\
\text { som, Exigências humanas }\end{array}$ & & \\
\hline Optativa & $\begin{array}{l}155527 \text { - GESTÃO } \\
\text { AMBIENTAL URBANA }\end{array}$ & & & \\
\hline Optativa & $\begin{array}{l}\text { 155543 - PROJETO } \\
\text { AMBIENTAL } \\
\text { INTEGRADO }\end{array}$ & $\begin{array}{l}\text { projeto envolvendo problemas concretos de } \\
\text { um edifício, abordando aspectos ambientais, } \\
\text { tecnológicos, físico-espaciais e construtivos } \\
\text { com auxílio de instrumentos computacionais. }\end{array}$ & $\begin{array}{l}\text { leituras, seminários, pesquisa, } \\
\text { exercícios, visitas de campo, } \\
\text { laboratório físico, laboratório } \\
\text { virtual (simulação), projeto }\end{array}$ & $\begin{array}{l}\text { exercícios, apresentação de } \\
\text { seminário, projeto desenvolvido, } \\
\text { maquete, participação, painel de } \\
\text { assessoramento }\end{array}$ \\
\hline Optativa & $\begin{array}{l}\text { Projetos Paisagísticos vinculados ao sistema de } \\
\text { áreas verdes urbanas, especialmente parques } \\
\text { urbanos, metropolitanos, temáticos ou áreas } \\
\text { reservadas. }\end{array}$ & & \\
\hline
\end{tabular}

*As disciplinas destacadas são de caráter obrigatório no currículo 